\author{
Universidade de São Paulo \\ Faculdade de Filosofia, Letras e Ciências Humanas \\ Departamento de Filosofia \\ Programa de Pós-Graduação em Filosofia
}

Octavio Paz e a compreensão da natureza do instante

Vinícius de Oliveira Prado

São Paulo

2019 



\title{
Octavio Paz e a compreensão da natureza do instante
}

\author{
Vinícius de Oliveira Prado
}

Dissertação apresentada ao programa de

Pós-graduação em Filosofia do departamento da Faculdade de Filosofia, Letras e Ciências Humanas da Universidade de São Paulo, para obtenção do título de Mestre em Filosofia sob orientação do Prof. Dr. Celso Fernando Favaretto.

São Paulo 

Autorizo a reprodução e divulgação total ou parcial deste trabalho, por qualquer meio convencional ou eletrônico, para fins de estudo e pesquisa, desde que citada a fonte.

\section{Catalogação na Publicação}

Serviço de Biblioteca e Documentação

Faculdade de Filosofia, Letras e Ciências Humanas da Universidade de São Paulo

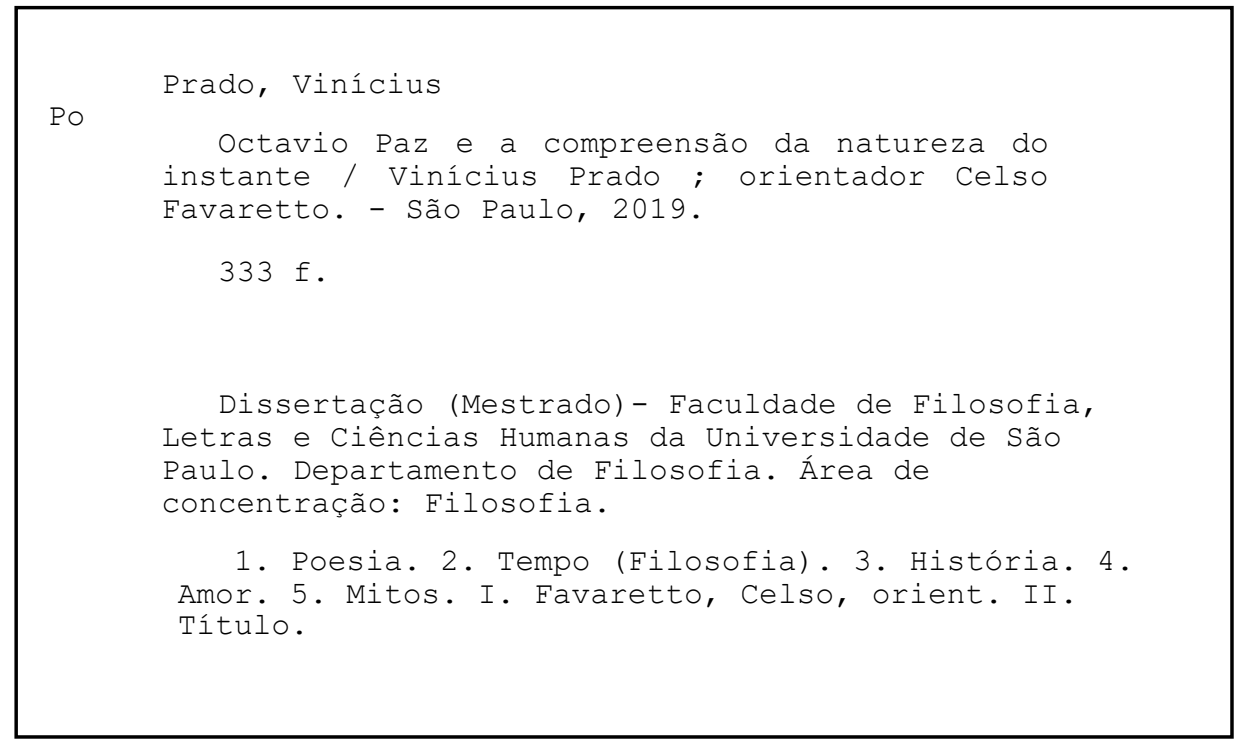





\section{Agradecimentos:}

Em primeiro lugar, agradeço a meus pais, Mario José Ducatti do Prado e Bernadete Frau de Oliveira Prado, pela paciência de explicar a todos que devem ter thes perguntado para que servia, afinal, meu curso de filosofia. Agradeço pelo incentivo e pelo suporte afetivo sempre ofertado sem mesura dado a mim e a meus irmãos, Mateus e Tiago de Oliveira Prado.

Ao meu orientador, Prof. Dr. Celso Favaretto, pela liberdade a mim confiada bem como pelas valorosas indicações de leitura, ampliadoras de meu horizonte, sobretudo acerca das dimensões estéticas e contemporâneas da temporalidade. Aos professores presentes em minha banca de qualificação, Prof. Dr. Horácio Costa, a quem devo o título desta dissertação bem como a sugestão de meu itinerário poético; e Prof. Dr. Ricardo Fabbrini, cuja leitura sempre atingiu os pontos nevrálgicos do texto, em busca de suas respectivas tensões, agradeço pela sugestão de divisão capitular, à qual tentei seguir, apesar da rebeldia da escrita. Agradeço também ao Prof. Dr. Eduardo Jardim pelo interesse e pela afabilidade com que aceitou o convite a esta banca.

À minha interlocutora cativa que, desde 2015, acompanhou com deslumbre e crítica o desenvolvimento destas ideias, posto que não posso dizer senão que nos desenvolvemos juntos nestes anos. Agradeço à Rafaella Gobbo (Fafá) por sua paciência, seu carinho, sua afetuosa sinceridade e seu amor (e, não menos importante, por me presentear com La llama doble, obra mais do que fundamental para a compreensão deste trabalho).

Aos amigos da Alétheia F.C., sobretudo Michel Amary, pelos brindes (ainda que poucos), assim como pelos passes conceituais e futebolísticos; à Maria Rita Morita, pelo companheirismo e por ter sido mais importante do que conveniente nesses anos de cumplicidade e pós-graduação, por ter sido uma irmã interiorana na selva de pedra; aos amigos do 508 do CRUSP, Érika e Cássio, pelos tantos dedos de prosa inspiradores e por terem sido instâncias de afeto nestes poucos, mas intensos anos; ao Pedro Cortês, pela naturalidade com que se manifesta curioso nos mais diversos assuntos, incluindo este trabalho;

Aos colegas do Grupo de Estudos em Estética Contemporânea da USP, sobretudo aos da organização do IV Seminário de Estética e Crítica de Arte da USP, Fernanda Albuquerque de Almeida, Luísa Bartalini, Anna Carolina Martins Ribeiro, Carolina Rodrigues Boaventura, Augusto César Lima, Olívia Lagua, Ruy Luduvice e Breno Isaac Benedykt, pelas questões discutidas, textos lidos e pelo que ainda virá em 2020.

Agradeço, finalmente, à CNPq pelo fomento e incentivo que possibilitou a realização deste trabalho, através do benefício a mim concedido (processo de № 169394/2017-4), bem como à Universidade de São Paulo que, com seus espaços de estudo e acervo bibliográfico, forneceram o material necessário para todo o desenvolvimento desta pesquisa. Agradeço também aos funcionários da secretaria, sempre aptos a nos auxiliar a desbravar/resolver os caminhos da estrutura burocrática universitária. 

Onde estarão os séculos, o sonho

de espadas pelos tártaros sonhado, onde as fortes muralhas derrubadas, onde a Árvore de Adão e outro Lenho?

O presente está só. É a memória que erige o tempo. Sequência e engano, essa é a rotina do relógio. $O$ ano é tão vazio quanto a vazia história. Entre a aurora e a noite há um abismo de agonias, de luzes, de cuidados; o rosto que se observa nos usados espelhos da noite já não é o mesmo. O hoje fugaz é tênue e é eterno; Não haverá outro Céu nem outro inferno.

(Jorge Luis Borges, O Instante) 



\section{Resumo:}

PRADO, Vinícius de Oliveira. Octavio Paz e a compreensão da natureza do instante. 2019. 333f. Dissertação (Mestrado) - Faculdade de Filosofia, Letras e Ciências Humanas. Departamento de Filosofia, Universidade de São Paulo, São Paulo, 2019.

Este trabalho visa explanar qual é a natureza do instante em Octavio Paz. Mais do que compreender como se configura este marcador temporal, nosso objetivo é investigar como esta questão opera, no interior da obra do autor, como uma força motriz a perpassar toda a sua produção ensaística e poética, sendo o ponto comum da complementaridade das diferentes modalidades discursivas. Para tanto, dividimos este trabalho em duas partes, onde, na primeira, realizamos uma leitura seletiva de seus ensaios, mostrando como estes se articulam em uma construção epistemológica do tempo coadunada à história, assim como uma visão de crítica que se situa para além da própria crítica tradicional racionalista e, por fim, como Octavio Paz constrói o método analógico; na segunda, realizamos um caminho de leitura que percorre três poemas de Paz, Pedra de Sol, Transblanco e Noturno de San Ildefonso, a fim de compreender como mito, história e amor enlaçam-se nestes poemas através da noção de instante.

Palavras-chave: Instante; Poesia; História; Mito; Amor. 



\begin{abstract}
:
PRADO, Vinícius de Oliveira. Octavio Paz and the comprehension of the nature of the instant. 2019. 333f. Thesis (Master) - Faculdade de Filosofia, Letras e Ciências Humanas. Departamento de Filosofia, Universidade de São Paulo, São Paulo, 2019.
\end{abstract}

This work intends to explore the nature of the instant in Octavio Paz. More than understanding how this time stamp is configured, our aim is to investigate how this question operates inside the author's work, like a thread that runs through the author's essayistic and poetic production, which is the common point inside the complementarity of the different kinds of discursive modality. For this purpose, this work is divided in two parts, where, firstly, we intend to show how they articulate themselves into a epistemological construction of time associated with a vision of History, as well as the concept of 'critics' apart from the traditional rationalistic vision of critics itself and, finally, how Octavio Paz builds the analogical method. Secondly, we intend to develop another sort of reading concerning three of the author's poems, Pedra de Sol, Transblanco and Noturno de San Ildefonso, in order to comprehend how myth, History, and love are intertwined by the notion of the instant.

Key-words: Instant; Poetry; History; Myth; Love. 



\section{Sumário}

Introdução:

1. Itinerário Ensaístico: formação do modelo epistemológico de Paz: 42

Octavio Paz encontra o anjo da história ..................................................................... 42

À beira da outra margem: Oriente e Ocidente ...................................................... 112

Marcel Duchamp: o mito da crítica e a crítica do mito .......................................... 167

Claude Lévi-Strauss e a consolidação do pensamento analógico ............................. 190

2. Itinerário Poético: O Mito, o Amor e a História: .............................................. 217

Pedra de Sol: o poema enquanto recriação do calendário e do mito ......................... 217

A experiência amorosa no poema Transblanco ...................................................... 275

Noturno de San Ildefonso: reencontrar a memória, recriar a história ...................... 301

Considerações finais:

320

Referências Bibliográficas: 


\section{Introdução}

Entre a poesia e o tempo há mais do que uma afinidade, há uma relação de identidade. Falar em um "fazer poético" do tempo parece falar do óbvio, como soam os pleonasmos. Assim seria, não fosse o tempo da poesia algo diverso, distinto do que nos habitua os cotidianos regulares. Nossa vida ordinária é marcada pela "rotina do relógio", plena de sequência e engano, acusa Borges. Como na abertura de Tempos Modernos de Chaplin, o correr dos ponteiros indica linearidade, sucessão e, o mais importante, pontualidade. O mundo do trabalho colonizou nossa maneira própria de ser, sendo que esta maneira é, ela própria, temporal. Mas esta temporalidade não é única: ela é, como pretendemos mostrar neste trabalho, plural. Reconhecer no tempo a pluralidade de interpretações, realizações e relações com o mundo histórico é reconhecer a pluralidade do ser humano: ser que, diante da finitude, toca o infinito quando se trata de criar, seja o ato de sua criação o próprio tempo ou a visão que temos dele. Por esta razão, este é um trabalho sobre Octavio Paz, poeta, ensaísta e pensador que teve no tempo o coração de muitas de suas obras sobre poesia, política e cultura, além de seus próprios poemas.

O tempo que se encarna na poesia parece a Octavio Paz dotado de uma pureza que nos remeteria a momentos históricos capazes de direcionar a nossa percepção acerca do mundo e da realidade à nossa volta. Como uma pedra arquetípica, sobre a qual se funda uma civilização, a palavra é capaz de fundar instantes originários, prontos a significar o tempo presente. Para Paz, ela é capaz de fundar instantes através da origem ou nos fazer "saltar" para a outra margem, isto é, para a outra realidade prodigiosa do mundo que a poesia busca consagrar a cada instante. Ainda que Paz não nos tenha dito isso, no alemão há uma similaridade entre origem e salto. Segundo nos conta Jeanne Marie Gagnebin,

\footnotetext{
“O Ursprung designa a origem como salto (Sprung) para fora da sucessão cronológica niveladora à qual uma certa forma de explicação histórica nos acostumou. Pelo seu surgir, a origem quebra a linha do tempo, opera cortes no discurso ronronante e nivelador da historiografia tradicional ${ }^{1 \prime \prime}$.
}

\footnotetext{
${ }^{1}$ GAGNEBIN, Jeanne Marie. História e narração em Walter Benjamin. São Paulo: Perspectiva, 2013. p. 10. [Negrito nosso].
} 
Ora, se no alemão, Gagnebin nos explica que a parelha Ursprung-Sprung guarda uma relação coerente, podemos afirmar que Paz abarca tanto o salto quanto a origem em uma única noção, a qual será o nosso objeto central nesta dissertação: o instante.

Conforme exporemos, o instante é uma presença que se manifesta tal e qual uma imagem de tempo, através de quatro eventos: em primeiro lugar, a poesia, o locus por excelência do instante enquanto a temporalidade que consagra um aqui e um agora; em segundo, a experiência da festa, onde o ser humano abandona a sua condição solitária e, entregando-se à coletividade, experimenta uma imersão comunitária em um regime de temporalidade que não poderia ser senão este que opera através do instante; em terceiro, a gesta da Revolta, em que a origem faz retornar do subterrâneo passado, de forma muitas vezes catártica, pulsões que levam à rebelião e a demanda - no agora por uma nova forma de vida; e, por fim, a experiência amorosa que, fundida à experiência poética, nos leva à outra margem e estabelece em nós o que Paz chamará de nossa "ração de eternidade". A partir destes quatro tipos de experiência, os quais contarão com nosso trabalho de análise, exegese e interpretação, visamos construir uma compreensão acerca da natureza desta imagem de tempo que, a nosso ver, é um dos principais temas deste poeta tão importante à tradição latino-americana.

A relação intrínseca do tempo com a poesia surge enquanto invenção e reinvenção de signos e significados, além de busca por novas configurações de vida e a construção de identidades. Como isto é feito? Ora, determinar os elementos que contribuem para a construção de novas temporalidades é uma tarefa que não se esgota na tarefa da interpretação cultural, na análise da relação dialética entre materialidade e subjetividade, tampouco na investigação filosófica da própria interioridade. A dificuldade inerente à questão sobre 'o que é o tempo', ainda que não extravase a capacidade humana de formular respostas teóricas, às vezes, tem na própria linguagem uma de suas barreiras. Esta dificuldade é atestada na célebre passagem das Confissões agostinianas, onde o bispo de Hipona diz, sobre o tempo, que "se ninguém me pergunta, eu o sei; mas se me perguntam, e quero explicar, não sei mais nada"'. O ato de pôr-se a

\footnotetext{
${ }^{2}$ AGOSTINHO, Santo. As confissões. Trad. Frederico Ozanam Pessoa de Barros. São Paulo: Edameris, 1964.
} p. 17. 
pensar, a verbalizar e a tentar trazer à luz a natureza do tempo é, por vezes, afastar-se de seu sentido verdadeiro. Por conta disso, toda vez que o poeta se propuser a dizer não apenas o tempo, mas a realidade primordial das coisas, podemos afirmar que estará realizando uma aposta. Tal como Mallarmé, de quem Octavio Paz em boa parte extrai o sentido plural de seus poemas, em cada verso, assim como em cada pensamento, o poeta realiza um lance de dados.

Em Ruptura y convergencia, seção inicial de La Otra Voz, Paz traça um breve diagnóstico das questões que, em 1990, permearam um de seus últimos ensaios:

\begin{abstract}
"Asistimos ahora a la quiebra de las dos ideas que han constituido a la modernidad desde su nacimiento: la visión del tiempo como sucesión lineal y progresiva orientada hacia un futuro cada vez mejor y la noción del cambio como la forma privilegiada de la sucesión temporal. Ambas ideas se conjugaron en nuestra concepción de la historia como marcha hacia el progreso: las sociedades cambian sin cesar, a veces de manera violenta, y cada uno de esos cambios es un avance. El tiempo arquetípico dejó de ser el pasado y su quimérica edad de oro; a su vez, el tiempo fuera del tiempo, la eternidad de los ángeles y los diablos, los justos y los réprobos, fue desalojada por el culto al progreso. La tierra prometida fue el futuro. En la esfera de la acción política, la manifestación del cambio fue la idea de Revolución; en el dominio del arte y la literatura, la idea del arte nuevo, fundada en la ruptura con el pasado inmediato. Hoy el futuro ha dejado de ser un imán y se desvanece la visión del tiempo en que se sustentaba y que lo justificaba. Con ella, se evapora también el gran mito que inspiró a tantos en el siglo XX, la Revolución. Su ocaso coincide con el de las vanguardias artísticas y poéticas. No es extraño: el arte moderno nació como una respuesta - a un tiempo eco y réplica - de la Revolución francesa, con la que se inaugura la modernidad; su suerte se confunde con la de la idea revolucionaria ${ }^{3 \prime}$.
\end{abstract}

Neste trecho, podemos perceber como as visões de tempo, bem como a percepção acerca de seu transcorrer, atuam como norteadores de concepções fundamentais à

\footnotetext{
${ }^{3}$ PAZ, O. La otra voz. In Obras Completas, Vol. 1, La Casa de La Presencia; Ciudad de México: Fondo de Cultura Económica, 2003. p. 494.
} 
vida, como é o caso da história. Entre a história e o tempo arrolam-se transfigurações, contradições, afirmações, em que o segundo aparece sempre como condição do primeiro termo. As visões de tempo que possuímos são históricas e a história é transfigurável pelo tempo. Por isso, Octavio Paz preocupa-se tanto com a imagem que podemos ter do tempo, pois não vivemos senão em épocas de indefinições históricas e riscos pouco delimitados, como nos adverte o autor acerca do futuro: "Cada época se identifica con una visión del tiempo y en la nuestra la presencia constante de las utopias delata el lugar privilegiado que tiene el futuro para nosotros ${ }^{4 \prime \prime}$.

Esta forma de transfigurar a história é levada, muitas vezes, a cabo pela própria poesia. Uma poética, como a romântica, por exemplo, instaurou uma sensibilidade capaz de opor ao espírito presente no curso da história os eventos e formas de sentir suplantados por ela e sua marcha inexorável: "Hijo rebelde, el romanticismo hace la crítica y opone al tiempo de la historia sucesiva el tiempo del origen antes de la historia, al tiempo futuro de las utopías el tiempo instantáneo de las pasiones, el amor y la sangre ${ }^{5 \prime}$. De certa forma, na construção da noção de instante, podemos afirmar que Paz bebe de diversas fontes. De um lado, a múltipla tradição oriental, sobretudo as doutrinas hindu e budista do tantrismo e, de outro, a tradição romântico-surrealista, bem como a poesia moderna mexicana, expressada pelo grupo Contemporâneos, com quem Paz manteve ambígua relação, como nos mostra Stanton:

\footnotetext{
“En esta doble negación - de la poesía pura y del arte dirigido - se vislumbra la todavía confusa afirmación de una poética personal que trata de provocar una síntesis entre los dos polos y así unir poesía e historia en un equilibrio tenso y fecundo. El texto de este período que mejor expresa esta naciente poética es «Poesía de soledad y poesía de comunión» de 1943. Aquí se asume el «propósito que intenta unir dos tendencias paralelas del espíritu humano: la conciencia y la inocencia, la experiencia y la expresión, el acto y la palabra que lo revela» (p. 303). Proyecto totalizador y utópico: ciencia y paciencia, razón e
}

\footnotetext{
${ }^{4}$ Ibidem. p. 502.

${ }^{5}$ Ibidem. p. 503.
} 
inspiración, historia y metafísica, no como irreconciliables contrarios sino como dos caras gemelas del ser total ${ }^{6 \prime}$.

Octavio Paz foi um poeta que conseguiu realizar, através de sua poética do instante, a conciliação de contrários aparentemente insuperáveis. Em nossa dissertação, pretendemos mostrar como o poeta percorre este caminho não apenas na poesia, onde a permissão para a perambulação livre do pensamento nem sempre é questionada, mas também no ensaio, construindo um repertório que, a nosso ver, conformará - através do estudo de Paz acerca de determinadas figuras - uma teoria do conhecimento poético, a bem dizer, uma epistemologia sensível que nos possibilita abarcar o contraditório, uma vez que foca na relação entre dois termos, sempre intercambiáveis, porém conciliáveis segundo a poesia.

Esta epistemologia, extraída de fontes tão alhures, marca da originalidade de Octavio Paz, é o que a crítica Maria Esther Maciel chama de pensamento ou método analógico $^{7}$. Este método pode ser compreendido como uma aposta do autor para os tempos de desagregação e queda na malha histórica que vivemos. Contudo, a busca pela ruptura com este mundo não deve ser uma busca que aniquilará a crítica. O método analógico de Paz é uma proposta de pensamento que conciliará duas tendências diversas de nosso pensamento: a analogia, que conecta as coisas mais díspares ao tomar as imagens como polos gravitacionais que se atraem e a ironia, seu oposto, aquela que estabelece a marca da ruptura, nossa "consciência de morte", como aponta em Os Filhos do Barro. A proposta de Paz, conforme se verá, será a de uma poética que seja, ao mesmo tempo imaginativa, mas crítica. Neste sentido, o pensamento do poeta se assimila ao trabalho do tradutor, a quem cabe criticar e conciliar. Segundo Horácio Costa, podemos definir esta atividade da seguinte maneira:

\footnotetext{
${ }^{6}$ STANTON, Anthony. Octavio Paz y los "contemporáneos": la historia de una relación. In A. VILANOVA ed., Actas del X Congreso de la Asociación Internacional de Hispanistas. Barcelona: Univ. De Barcelona/ PPU, 1992, tomo 4. p. 1006.

7 Cf. MACIEL, Maria Esther. As Vertigens da Lucidez: poesia e crítica em Octavio Paz. São Paulo: Experimento, 1995.
} 


\begin{abstract}
"'Traduzir", no sentido mais amplo do termo, implica conciliar, criticar e dialogar, e também relativizar, "transicionalizar", se é possível arriscar o neologismo. Só pode traduzir quem assume uma postura transicional: o tradutor está, literalmente, em trânsito, não apenas entre o que verte e o vertido - quando se dá, no âmbito da tradução literária, e como tão bem postula Haroldo de Campos, a re-criação -, mas também, no processo tradutório, encontra-se este criador sui-generis traduzindo-se a si mesmo, em trânsito em, e para, si mesmo ${ }^{8 \prime}$.
\end{abstract}

Portanto, podemos afirmar que Paz trabalhou não apenas como o conciliador de tradições diferentes, mas como seu crítico ativo. Em seu papel de poeta, a sua capacidade de estabelecer pontes e analogias entre mitos, culturas, práticas, rituais, festas e gestos políticos diferentes se deveu, em boa parte, graças à sua atividade como tradutor. Um tradutor de signos e símbolos, de imagens e ritmos, em suma, de formas de viver o tempo.

Intentamos desvelar, por trás da postura do crítico, o olhar de um poeta que elabora um pensamento próprio acerca da arte e do tempo, dois temas caros à filosofia e que estão aqui interligados, em conexão íntima, sob uma teoria que não é exclusivamente conceitual, mas imagética, poética e crítica - três caminhos do conhecimento que, em Paz, não estão separados por trifurcações solipsistas. Contudo, sabemos que o pensamento crítico dificilmente abre mão dos conceitos e que, às vezes, para demarcar posição, é necessário fazê-los operar para aplicar o ponto de vista analítico sobre eventos e fenômenos da história. A exemplo disto, ainda que Paz se valha das imagens para pensar algo complexo como o tempo, é possível ver em suas análises da tradição moderna a aplicação de determinados conceitos para explicar como ela se desenrola na história, por exemplo, como ocorre com a ideia de "tradição da ruptura". Este é um conceito que, à sua vez, opera como uma metáfora crítica, como uma imagem prenhe de negatividade, capaz de abarcar em seu interior a complexidade de um fenômeno histórico que o simples pensamento analítico tergiversaria em arriscar uma definição. A perspectiva crítica não pode abdicar de todo do conceito, entretanto, ela

\footnotetext{
${ }^{8}$ COSTA, Horácio. O traduzir como necessidade e como projeto In MACIEL, Maria Esther (Org.) A palavra inquieta: homenagem a Octavio Paz. Belo Horizonte: Autêntica, 1999. p. 30.
} 
pode abrir espaço à imagem ou aos conceitos que operem tais como as imagens. Em suma, abaixo explicaremos como este trabalho, dividido em duas partes, se dará.

A sua primeira parte, intitulada "I. Itinerário ensaístico: formação do modelo epistemológico de Paz" expõe um caminho pelo qual estabelecemos uma ordem de leitura, que nos possibilita visualizar isso que chamamos de "modelo epistemológico" ou, simplesmente, método analógico, bem como as teorizações que Paz realiza acerca da história e do próprio tempo, além de temas adjacentes. Seus capítulos referem-se aos temas gerais que abordamos em cada capítulo: em primeiro lugar, temos "Octavio Paz encontra o anjo da história", onde trataremos do pensamento que o poeta constrói acerca da história e sua relação com o tempo. Neste mesmo capítulo, exporemos como Octavio Paz se apresentou como leitor de Sor Juana Inés de la Cruz, em sua obra As Armadilhas da Fé, e como, no interior de sua atividade de biógrafo, reside uma concepção de história que desemboca, por sua vez, numa concepção de imagem de tempo coerente com o instante, tal como formulado em seus outros textos poéticos e ensaísticos. Em segundo lugar, temos o capítulo "À beira da outra margem", onde estudamos o percurso de Paz em sua obra Conjunções e Disjunções acerca do pensamento místico e das religiosidades orientais, abarcando a experiência da festa e da revolta. Em terceiro, "Marcel Duchamp: o mito da crítica e a crítica do mito", analisamos como Paz se propõe a pensar, através de Marcel Duchamp ou o Castelo da pureza, um dos principais artistas das vanguardas europeias para refletir sobre a viabilidade contemporânea da noção de crítica. Neste capítulo, discutiremos os sentidos da racionalidade ocidental, movimentada pelo seu desenvolvimento instrumental, e como esta mesma racionalidade aparece como mito a ser criticado na obra de Duchamp, assim como este mesmo mito se volta sobre si mesmo fundando outra coisa, no caso, um resgate da analogia. Por fim, o quarto e último capítulo desta parte "Claude LéviStrauss e a consolidação do pensamento analógico" parte da leitura que Paz desenvolveu acerca do antropólogo francês. Tendo esta sua leitura se tornado constitutiva no desenvolvimento de seu pensamento analógico, acreditamos que ela opera, por assim dizer, como um modelo de ciência que restabelece e conjuga dois mundos que, até então, pareciam irreconciliáveis: ocidente e oriente. 
A segunda parte deste trabalho, intitulada Itinerário Poético: O Mito, o Amor e a História elegeu três poemas de Octavio Paz para exegese e interpretação. Produzidos num arco de vinte anos de produção, Pedra de Sol (1956), Transblanco (1967) e Noturno de San Ildefonso (1976) são poemas que compartilham de certa continuidade, apesar da enorme diferença em suas formas, tamanhos e conteúdo. Neles, é possível vislumbrar a persistência de certas imagens bem como certos temas, a saber: o amor, o erotismo, a própria poesia (e sua experiência), a história e, por fim, o tempo. Mas, os temas que focamos em nossa análise, respectivamente, giram em torno do mito, do amor e da história. Ainda que estes três temas se entrelacem e tragam outros, são estes o núcleo de cada capítulo de nossa leitura sequencial. Estes capítulos se intitulam, respectivamente, "Pedra de Sol: o poema enquanto recriação do calendário e do mito"; "A experiência amorosa no poema Transblanco"; e, por fim, "Noturno de San Ildefonso: reencontrar a memória, recriar a história".

Nesta primeira parte, trataremos da experiência mística e da experiência crítica, presente tanto nos objetos de reflexão de Paz como em alguns de seus poemas. Pensar esta questão requer que tenhamos os olhos voltados para as figuras que foram importantes para que Paz construísse seu pensamento. Ainda que a miscelânea de temas bem como autores analisados por Paz não se esgote nestes aqui escolhidos, daremos ênfase nas análises que o mexicano faz acerca das figuras citadas, uma vez que nestas obras Paz constrói conceitos que serão utilizados em toda a sua obra, assim como imagens que lapidarão suas ideias em possibilidades poéticas e narrativas. Porém, antes, é necessário dizer que o "místico" não deve ser entendido como o transcendente e o extra-sensorial, mas como aquilo que está ligado ao sagrado que é, por sua vez, um aqui e agora. O que constrói a sacralidade, para Octavio Paz, é o contato com aquilo que é radicalmente outro: alteridade radical, heterogeneidade, outridade. Assim como o eu se conecta ao outro através de uma relação, podemos afirmar que a construção do que quer que venha a ser o sagrado também se dá numa relação com o profano. Nos termos de Octavio Paz, esta relação pode ser vislumbrada através de dois conceitos que discutiremos neste capítulo: corpo e não-corpo. Mas, mais importante é o que se dá entre estes dois polos contraditórios, isto é, a própria ideia de relação: aquilo que 
interliga opostos, que conecta contradições e que, tal como na linguagem poética, estabelece pontes e identidades.

O outro para Paz sempre foi uma imagem-conceito central, presente nas reflexões sobre poesia, cultura, política e amor. A importância desta noção pode ser equiparada à ideia de tempo, tanto que entre as duas haverá uma conexão íntima: a temporalidade do outro, a temporalidade do encontro. Além disso, convém pensar como a eleição de determinados outros foi essencial para a construção do pensamento de Paz. Basicamente, a pergunta que nos fazemos neste capítulo é: Por que Índia? Por que Sor Juana Inés de la Cruz? Por que Marcel Duchamp? Por que Lévi-Strauss? Estamos certos de que para cada uma destas perguntas, há uma motivação e uma resposta diferentes. No entanto, a escolha por estes nomes e temas auxilia no estabelecimento de uma coerência que só é possível de ser compreendida à luz de um pensamento que, como pretendemos mostrar no interior desta dissertação, é poético.

Em primeiro lugar, o que significa "outridade"? Para Paul Henri Giraud,

\footnotetext{
"situado simultaneamente sobre o plano da essência e sobre o plano da existência, o neologismo otredad designa, em António Machado, a "heterogeneidade essencial do ser": esta alteridade radical que se cava no próprio seio do ser e que faz com que este não seja apenas Uno, o Mesmo, mas também o Outro, simultaneamente desconhecido e apaixonadamente desejado'".
}

Haveria, portanto, em Paz como em António Machado, uma dialética entre o Uno e o Outro, funcionando como um constante devir no tecido da existência e do Ser. Esse neologismo também significa uma condição, a imperiosa necessidade que nos move em busca do outro e que, como se verá posteriormente, está intimamente associada à nossa condição temporal. Os termos extremos desta relação dialética seriam, portanto, a comunhão e a solidão. Paz tem num dos seus mais importantes ensaios, O Labirinto da

\footnotetext{
${ }^{9}$ GIRAUD, Paul Henri. Octavio Paz: caminho para a transparência. Trad. António Teixeira. Lisboa: Instituto Piaget, 2002. p. 21.
} 
Solidão de 1950, a realização de um diagnóstico preciso da modernidade: todos nós estamos sós. A solidão, outrora figurada como característica pessoal, subjetiva, é hoje condição universal, cada vez mais determinante no tecido das nossas relações sociais. Para aquele que é poeta, esta questão nunca foi um problema, uma vez que no diálogo que estabelece com o mundo, "o poeta parte da solidão, movido pelo desejo, na direção da comunhão ", sobretudo se a condição histórica de poeta for similar à condição do latino-americano, isto é, condição que diz que

\footnotetext{
“de fato, sempre vivemos na periferia da história. Hoje o centro, o núcleo da sociedade mundial, se desagregou, e todos nos tornamos seres periféricos, até os europeus e os norte-americanos. Estamos todos à margem porque não há mais centro ${ }^{10 \prime \prime}$.
}

A solidão é universal bem como a marginalidade. Em razão disto, Octavio Paz se vale da expressão "solitaire et solidaire" (solitário solidário) de Albert Camus.

A que se deve esse sentimento da solidão? Por que a sua manifestação é universal e por que o poeta surge aqui como agente capaz de transcender esta condição? Em primeiro lugar, a poética de Paz se volta para certa rememoração da origem, onde há a comunhão de ritmos, onde a palavra poética é comunitária e criadora. Origem que pode ser compreendida pelo sentimento onde, nas palavras do crítico francês Marcel Raymond em De Baudelaire ao Surrealismo, "renunciamos previamente a nos opormos ao mundo", e onde "o sentimento de nós mesmos e o sentimento do todo não são mais discerníveis. Experiência mística natural, este "grande Ser", que Rousseau continua a chamar Deus, é a vida universal, imanente, que sente em si mesmo como a maré alta11". Este sentimento pode ser compreendido como um estado de comunhão em que as coisas estão embotadas de sentido, marcadas por uma presença que as transcende. Raymond ainda acrescenta:

\footnotetext{
${ }^{10}$ PAZ, Octavio. O Labirinto da Solidão. Trad. Ari Roitman, Paulina Wacht. São Paulo: Cosac Naify, 2014. p. 163.

11 RAYMOND, Marcel. De Baudelaire ao Surrealismo. Trad. Fúlvia M. L. Moretto; Guacira Marcondes Machado. São Paulo: Edusp, 1997. Pag. 13.
} 
“Este estado feliz, "perfeito e pleno", inefável em si mesmo é também efêmero. Seu desaparecimento deixa ao homem uma consciência mais viva de seus limites e das condições de uma vida precária. Só terá repouso quando tiver novamente forçado as portas do Paraíso; na falta disso, somente quando tiver tirado proveito dessas revelações. Durante o êxtase, as palavras fogem, mas a lembrança do êxtase as chama de volta; as imagens brilham, como uma espuma sobre a vaga. Jogo da alma, mas que aspira a uma atividade mais elevada do que a do jogo, por mais nobre que seja, que aspira a recriar, pelo verbo, a felicidade perdida ${ }^{12 \prime}$.

Esta promessa de felicidade é um legado deixado pelas experiências romântica e surrealista. Nesta esteira, a experiência poética, para Paz, será marcada por uma tentativa de refundar este sagrado sem, no entanto, abrir mão do pressuposto moderno que moveu e tem movido a arte nas vanguardas: a paixão crítica. Poética do instante, do sagrado ou do divino, certo é que em Paz se construirá um pensamento aberto a uma experiência temporal outra, a uma experiência temporal a que teremos acesso por intermédio de seus ensaios, assim como de sua poesia.

Posta a solidão como marca condicional de nossa existência, a tarefa filosófica e poética do agora será a busca pelo outro. Em O Labirinto da Solidão, Paz apresenta em sua epígrafe a seguinte passagem de António Machado, destacada por Giraud na citação que apresentamos anteriormente:

\footnotetext{
“O outro não existe: essa é a fé racional, a crença incurável da razão humana. Identidade $=$ realidade, como se, afinal de contas, tudo tivesse que ser, absoluta e necessariamente um e sempre o mesmo. Mas o outro não se deixa eliminar; subsiste, persiste; é o osso duro de roer no qual a razão perde os dentes. Abel Martín, com fé poética, não menos humana que a fé racional, acreditava no
}

\footnotetext{
12 Ibidem.
} 
outro, na essencial Heterogeneidade do ser, como se disséssemos na incurável outridade de que o um padece ${ }^{13 \prime \prime}$.

No entanto, para Paz a persistência do outro não é constante, eis o motivo pelo qual o "eu" deve empreender uma busca, um esforço por encontrar o outro nos caminhos obtusos do ser. O outro pode vir sob a forma da negação ou da ruptura, por isso António Machado o apresenta como "osso duro de roer". É o recalcado, o oprimido, o esquecido pela tradição e pelo matiz histórico que se estabeleceu como a narrativa oficial.

Neste sentido, o crítico se aproxima do poeta, pois ambos liberam os outros que estão adormecidos no estofo do discurso padronizado ou da norma vigente, em busca de tradições que se apresentem como a alteridade radical àquela imposta como oficial. Ou seja, a busca pelo outro enquanto busca de uma origem é a jornada pela fundação de uma nova tradição. Podemos dizer, inclusive, que interrupção do contínuo temporal, narrativo ou histórico se assimila à passagem descrita por Proust, um pouco antes do momento em que o narrador nos conta sobre a mordiscada na madeleine e o gole de chá, no seguinte trecho que já conserva toda a ideia original presente no momento mais importante do romance, quando pensamos na mémoire involontaire. Trata-se da descrição do seguinte mito celta:

\footnotetext{
“Mas como o que eu então recordasse me seria fornecido unicamente pela memória voluntária, a memória da inteligência, e como as informações que ela nos dá sobre o passado não conservam nada deste, nunca me teria lembrado de pensar no restante de Combray. Na verdade, tudo isso estava morto pra mim. Morto para sempre? Era possível. Há muito de acaso em tudo isso, e um segundo acaso, o de nossa morte, não nos permite muitas vezes esperar por muito tempo os favores do primeiro. Acho muito razoável a crença céltica de que as almas daqueles a quem perdemos se acham cativas em algum ser inferior, em um animal, um vegetal, uma coisa inanimada, efetivamente perdidas para nós até o dia, que para muitos nunca chega, em que nos sucede passar por perto de uma árvore, entrar na posse do objeto que lhe serve de
}

\footnotetext{
${ }^{13}$ PAZ, Octavio. O Labirinto da Solidão. Trad. Ari Roitman, Paulina Wacht. São Paulo: Cosac Naify, 2014.
} Pag. 9. 
prisão. Então elas palpitam, nos chamam, e, logo que as reconhecemos, está quebrado o encanto. Libertadas por nós, venceram a morte e voltam a viver $\operatorname{conosco}^{14 \prime}$

Com isto, queremos dizer que a busca pelo outro é também uma busca para trazê-lo junto à nossa morada, ao que constitui a nossa existência no Ser. Por isso, como apontaremos adiante, as escolhas de Octavio Paz são tão significativas. Trata-se de eleger figuras, dentro do contínuo histórico, realizando um corte temporal sincrônico, que possibilita criar séries independentes cuja coerência será o desenvolvimento de uma ideia ou de uma imagem poética cuja potência será a de oferecer resistência aos ditames imperativos da temporalidade oficial. Muitas destas imagens serão míticas, talvez por pertencerem a uma racionalidade capaz de se impor de forma crítica, ainda que imagética, àquelas hipostasiadas pela razão instrumental sob a vaga ideologia do progresso.

Podemos pensar que o outro só o é por fazermos parte de uma comunidade existencial que tem no centro a temporalidade. Para Heidegger, segundo Benedito Nunes,

\footnotetext{
“o outro me é dado como outro; não se trata de um Eu alheio a ser conhecido, mas de um Eu alheio a ser compartilhado. Nada mais traiçoeiro do que o Eu no intercâmbio do cotidiano, que se desdobra, como já sabia Rimbaud, ou que se mascara, como já sabia Nietzsche antes de Fernando Pessoa. [...]. Se perguntarmos quem é esse Eu no intercâmbio cotidiano, veremos que já é e se manifesta como um outro de si mesmo sob o regime da mais completa alteridade. O alter ego me escuta, ri, fala, como instância autoritária, mas anônima, antes um ele censório, coator, do que um ato de confronto dialogal ou de oposição emudecedora. Quem é o outro, não se sabe, ele está em toda
}

${ }^{14}$ PROUST, Marcel. Em Busca do tempo perdido. V.1. No caminho de Swann. Trad. Mário Quintana. São Paulo. Ed. Globo. 2006. p. 70. 
parte; são todos e é ninguém; é como um gigantesco indivíduo sem rosto ou como a presença abstrata do ser coletivo ${ }^{15 "}$.

O que Heidegger questiona não é apenas o peso ontológico da relação - que se estabelece entre o um e o outro, entre a identidade pessoal e a alteridade -, mas também seu vigor existencial. O ser-aí, para o alemão, vincula-se ao ser-no-mundo que, por sua vez, só o é se assumimos que este diz ser-com-o-outro. Ou seja, mesmo na mais ensimesmada individualidade, há o despertar possível de um estar em companhia, pois o que me liga ao mundo inclui, necessariamente, os outros que nele habitam temporalmente. É por esta razão que o ser humano é um ser que se desdobra no tempo, pois só está com o outro que compartilha de sua "comunidade temporal". Contudo, é preciso ter em mente que o outro nunca deverá ser compreendido como uma extensão de mim mesmo. Paz afirmará que entre o um e o outro será possível uma correlação de identidade "meu eu é tu", porém, esta operação poética deve ser compreendida como uma ponte dinâmica que não anula uma das partes, por isto mesmo, dialética. Ainda para Heidegger, em El concepto de tiempo,

\footnotetext{
"La información sobre el ser-ahí de los otros, que estuvieron conmigo y que llegaron al fin, es una mala información. De pronto su ser-ahí ya no es. Su fin sería, en realidad, la nada. Por esto el ser-ahí de los otros es incapaz de sustituir al ser-ahí en sentido proprio, si el respectivo ser de cada uno ha de retenerse como mío. Nunca tengo el ser-ahí del otro en la forma originaria, que es el único modo apropiado de tener el ser-ahí: yo nunca soy el otro ${ }^{16 \prime \prime}$
}

Quando Heidegger diz, portanto, que "nunca sou o outro", com isto ele está afirmando que o que eu retenho do outro não é seu Dasein originário, mas apenas seu Ser-com-o-outro que me é dado pelo Ser-no-mundo. O que possibilitaria, portanto, esta conexão

\footnotetext{
15 NUNES, Benedito. A questão do outro em Heidegger. Nat. hum., São Paulo, v. 3, n. 1, p. 51-59, jun. 2001. Disponível em <http://pepsic.bvsalud.org/scielo.php?script=sci arttext\&pid=S151724302001000100002\&lng=pt\&nrm=iso>. (Acesso em 17 de maio de 2019). ${ }^{16}$ HEIDEGGER, Martin. El concepto de tiempo. Trad., Prol e Not. Raúl Gabás Pallás y Jesús Adrian Escudero. Madrid: Ed. Trotta, 2006. p. 46.
} 
íntima apresentada por Octavio Paz é o mesmo pano de fundo que possibilita a alteridade no pensamento heideggeriano: o estar no tempo, a temporalidade compartilhada. A nosso ver, Octavio Paz aprofundará a experiência entre o eu e o outro de forma mais completa, ao pensar no encontro como a experiência da outridade por excelência. Contudo, agora iremos analisar aqueles que no interior da alteridade radical, para Paz, serão experienciados como a sua outra voz, aquela que não será exatamente a sua, tampouco exclusivamente a do outro, possibilitando que nos perguntemos, por vezes: quem aqui fala?

Octavio Paz conclui Conjunções e Disjunções fazendo uma defesa do presente e indicando como a sociedade ocidental, que vislumbra o esgotamento da imagem de tempo teleológica e linear, pode reencontrá-lo. Para além de uma postura poética, trata-se de uma resposta que funda uma erótica. É preciso notar que Paz apresenta a irrupção do presente, esta temporalidade que o instante poético é capaz de trazer à tona, como "regresso". Ora, regresso de onde, de qual passado? Octavio Paz nos apresenta o presente, mas não diz sua origem concreta. Nesta obra, podemos compreender que as "revoltas" de 1968 indicam esta origem quando colocam a vida afetiva no centro de suas atividades. A rebelião destes anos complementa a tríade surrealista já composta por amor e poesia e nega a vigência do signo não-corpo, ou seja, possibilita em nossos tempos - partindo do pressuposto de que vivemos uma continuidade dos fatos ocorridos em 1968 - a emergência do signo corpo, esperando "reencarnar", isto é, manifestar-se em carne novamente no aqui e agora. Portanto, a origem do presente residiria no signo corpo. Não o corpo hipertrofiado das academias, do ideal austero de saúde, tampouco da modelo anoréxica das passarelas, pois estes ideais operam como descorporificadores, uma vez que desprovidos de vida e sentido, como indicaremos em nossa leitura de Byung-Chul Han ${ }^{17}$. Tampouco a representação do ideal clássico de beleza, mas, sim, assim como o tempo e a história, uma beleza plural e uma figura do corpo dotada de sentido.

\footnotetext{
${ }^{17}$ HAN, Byung-Chul. Sociedade do cansaço. Trad. Enio Paulo Giachini. 2a ed - Petrópolis, RJ: Vozes, 2017.
} 
Vivemos uma demanda por reconhecimento do belo no corpo do outro e isso passa, necessariamente, por não o relegar ao signo não-corpo, mas em manter a conjunção entre estes signos em permanente equilíbrio. Em vista disso, o poeta dirá que

\footnotetext{
"o tempo que desponta se define como um agora e um aqui. Por isso é uma negação do signo não-corpo em todas suas versões ocidentais, as religiosas ou atéias, as filosóficas ou políticas, as materialistas ou idealistas. O presente não nos projeta em nenhum além [...], mas na medula, no centro invisível do tempo: aqui e agora. Tempo carnal, tempo mortal: o presente não é inatingível, o presente não é um território proibido ${ }^{18 "}$.
}

Outra forma de resgatarmos este tempo presente e torná-lo experiência fundante de nossa imagem de tempo é o amor. Para Paz, cujas críticas a Maio de 1968 embalavam forte desconfiança ao apreço dos jovens franceses em relação ao regime maoísta, se a rebelião, onde quer que ocorra, não degringolar

\begin{abstract}
"em sistemas autoritários e fechados, se articular sua paixão na imaginação poética, no sentido mais livre e amplo da palavra poesia, nossos olhos incrédulos serão testemunho do despertar e volta a nosso abjeto mundo dessa realidade, corporal e espiritual, que chamamos presença amada. Então o amor deixará de ser experiência isolada de um indivíduo ou de um par, uma exceção ou um escândalo... Pela primeira vez e última aparecem nestas reflexões a palavra presença e a palavra amor. Foram a semente do Ocidente, a origem de nossa arte e de nossa poesia. Nelas está o segredo de nossa ressurreição ${ }^{19 \prime \prime}$.
\end{abstract}

Quando amamos, vivemos o misto de movimento e imobilidade, contínuo transcorrer e eternidade. Por esta razão, o amor será a expressão mais bem-acabada da ideia de instante e, portanto, a manifestação necessária para a compreensão de sua natureza.

\footnotetext{
${ }^{18}$ PAZ, Octavio. Conjunções e Disjunções. Trad. Lucia Teixeira Wisnik. São Paulo: Perspectiva, 1979. p. 133.

19 Ibidem.
} 
Há uma frase de Baudelaire que diz: "Toda poesia lírica, devido à sua natureza, opera fatalmente um regresso ao Paraíso perdido ${ }^{20 "}$. Esta afirmação que caracteriza o poeta como um ser lançado ao mundo, deslocado, alheio e solitário é condição do fazer poético assumido por Octavio Paz. Sua poesia, bem como seus ensaios, apontam para a necessidade de um regresso à origem, para uma volta ao que Baudelaire se referiu como "paraíso perdido". Este caminhar do poeta torna-se, então, um peregrinar entre as palavras rumo à origem fundadora, rumo a este estado onde a alma se encontra, novamente, com as coisas mesmas que nomeia. Contudo, ao contrário do que pode parecer, não é reproduzindo um sentido religioso arcaico que irá se firmar em sua poética esta busca. Como afirmamos, esta é uma busca que se dará, sobretudo, no seio do tempo. Em o Arco e a Lira, assim o mexicano define o que compreende por poético:

\footnotetext{
"Toda vez que o leitor revive de verdade o poema, atinge um estado que podemos chamar poético. Tal experiência pode adquirir esta ou aquela forma, mas é sempre um ir além de si, um romper os muros temporais para ser outro. [...] O poema é mediação: graças a ele, o tempo original, pai dos tempos, se encarna num instante. A sucessão se transforma em presente puro, manancial que se alimenta a si mesmo e transmuta o homem ${ }^{21 \prime \prime}$.
}

O rompimento dos muros temporais, aludido na citação acima, só é possível graças à natureza do instante em que o poeta participa da experiência criadora e amorosa. Neste instante, Marcel Raymond afirma que o poeta, na esteira da tradição romântica e moderna, busca "libertar a alma", ou seja, deverá partir ao encontro, novamente, do "estado natural", que era, em suma, "esta esperança senão a consequência de um sonho ancestral semimergulhado no inconsciente, o sonho de um universo mágico, em que o homem não se sentiria separado das coisas ${ }^{22 "}$. Ou seja, o fim de todo intermediário entre sujeito e objeto, ao passo que um se torna extensão do outro. Discorreremos como o método analógico de Paz encontra em Lévi-Strauss e na tradição indiana e

\footnotetext{
${ }^{20}$ GIRAUD, Paul Henri. Octavio Paz: caminho para a transparência. Trad. António Teixeira. Lisboa: Instituto Piaget, 2002. p. 33.

${ }^{21}$ PAZ, Octavio. O Arco e a Lira. Trad. Ari Roitman e Paulina Wacht. São Paulo: Cosac Naify, 2012. p. 33.

22 RAYMOND, Marcel. De Baudelaire ao Surrealismo. Trad. Fúlvia M. L. Moretto; Guacira Marcondes Machado. São Paulo: Edusp, 1997. p. 15.
} 
oriental as vias de como aceder a este estado de transparência no interior do instante poético. Mas, ainda sobre este instante, Octavio Paz afirma no ensaio Poesia de solidão e poesia de comunhão que

\footnotetext{
"Já dizia Nietzsche: Não a vida eterna, mas a eterna vivacidade: eis o que importa. Mostrar essa condição perecível talvez possa ser trágico; de fato, é, porém encontro nesse elemento o verdadeiro valor, no sentido de valioso e de valoroso, da poesia, pois ela resgata o cotidiano da vulgaridade e unge o instante com o irreparávelel".
}

A construção do novo sagrado passa pela realização do instante poético enquanto experiência temporal da vivacidade. Se, em O Arco e a Lira, Paz afirmou que o instante poético é o instante capaz de conter a todos os instantes e que, por isto mesmo, seria a chave de abertura do humano à história e ao próprio tempo, considerando a relação dialógica entre estes dois polos, de que forma este instante pode vir a dialogar com as temporalidades que regem nosso mundo? De que maneira o amor, enquanto experiência que, muitas vezes, possui uma durabilidade frágil, pode vir a ser a experiência por excelência do instante que funda sua poética? Pretendemos trazer alguma luz a estas perguntas nas linhas que se seguem.

A princípio, consideramos que a iminência de um possível conflito nuclear durante os anos de guerra fria; os traumas dos Processos de Moscou na intelectualidade socialista de esquerda, da qual Paz se afasta, apesar do diálogo que manteve com André Breton, Pablo Neruda, Júlio Cortazar e outros e; para citar mais um fator, a irrupção de revoltas juvenis nos anos 60 e 70, levam o mexicano a declarar em sua obra Tiempo Nublado que

\footnotetext{
"desde fins do século XVIII, vivemos o mito da Revolução, como os homens das primeiras gerações cristãs viveram o mito do Fim do mundo e da iminente volta de Cristo. Confesso que, à medida que passam os anos, vejo com mais simpatia
}

\footnotetext{
${ }^{23}$ PAZ, Octavio. Poesia de Solidão e Poesia de Comunhão In A Busca do Presente. Trad. Eduardo Jardim. Rio de Janeiro: Bazar do Tempo, 2017. 25.
} 
a revolta que a revolução. A primeira é um espontâneo e quase sempre legitimo levantamento contra o poder injusto. $O$ culto à revolução é uma das expressões da desmesura moderna ${ }^{244}$.

Antes que se entenda erroneamente Paz como um reacionário, é preciso dizer que é impossível dissociar a citação acima de uma das figuras mais complexas da configuração do poder mexicano: o PRI, Partido Revolucionário Institucional. A conjunção revolução e instituição era algo que espantava até mesmo o espírito poético de Paz, para quem a transgressão era fator importante da criação. Contudo, neste caso, Paz entende que a composição do Partido se tornou algo tão problemático que o fez reproduzir estruturas arcaicas em seu interior, bem como se tornar um instrumento de manutenção do poder e da petrificação da própria mudança. Neste sentido, o mexicano oferece uma interpretação de que o Partido, bem como os atos que perpetra no Estado Mexicano, são reproduções de formas de dominação ancestrais, como a do próprio sacrifício.

Em sua carreira diplomática, Octavio Paz pôde se tornar o cosmopolita que fez sua obra possível. Contudo, o episódio da interrupção de sua carreira de embaixador mexicano é o que possui mais destaque em sua biografia política. No ano de 1968, Paz acompanha as revoltas juvenis nos mais diversos lugares do mundo, do ocidente ao oriente. Em seu país natal, a Praça das Três Culturas - ou Plaza de Tlatelolco - localizada no centro histórico da Cidade do México, antiga Tenochtitlán, assistiu ao chamado "Massacre do Tatlelolco", quando jovens estudantes que protestavam contra a realização dos Jogos Olímpicos na cidade mexicana foram duramente reprimidos pelo poder do Estado. Nesta ocasião, as Forças Armadas mexicanas abriram fogo contra a oposição política, num dos episódios mais sangrentos do que ficou designado como Guerra Suja. De todo modo, Paz que, na época, trabalhava em Nova Délhi, foi levado a deixar a embaixada mexicana na Índia, após os eventos de 2 de outubro. Tal gesto, para Enrique Krauze, corroborou a simpatia que Paz nutria pelas revoltas. Ainda que Paz tenha se colocado disponível aos serviços do governo mexicano, o que talvez

\footnotetext{
${ }^{24}$ Id. Tiempo Nublado. Barcelona: Ed. Seix Barral, 1996. p. 27. (Tradução nossa).
} 
considerasse uma atitude cidadã, não pôde deixar de declarar seu posicionamento enquanto funcionário.

Porém, o que o intelectual nos diz acerca dos eventos ocorridos nesta data vai além da simples análise política, uma vez que expõe como se destaca a conjunção de imagens de tempo, bem como de práticas míticas diversas, lá presentes. No Posfácio de O Labirinto da Solidão, escrito a propósito dos acontecimentos ocorridos nesta data, o escritor mexicano retoma o tema da revolta e afirma que a demanda juvenil presente nos movimentos dos estudantes consiste na aparição espontânea da palavra maldita, descolada do mundo moderno, que retorna numa "irrupção do agora ${ }^{25 ", ~ o ~ p r a z e r . ~ O s ~}$ jovens estudantes trazem consigo a demanda do corpo e, para Paz, este momento configura uma revolta que busca o tempo presente. Para ele, apenas uma sociedade tecnológica pode fazer a pergunta necessária a nossos dias:

\footnotetext{
“Passado, presente e futuro, qual é o verdadeiro tempo do homem, onde está seu reino? E se esse reino é o presente, como inserir o agora, por natureza explosivo e orgiástico, no tempo histórico? A sociedade moderna precisa responder a essas perguntas sobre o agora - agora mesmo ${ }^{26 \prime \prime}$.
}

Estas revoltas configuram o que, para Paz, corresponde a uma irrupção, pois conjugam, convergem e contém uma série de elementos soterrados pela uniformidade dos regimes de "progresso" presentes nos mais diversos países. Em suma, quando Paz se refere a isto como "irrupção", concretamente, ele está falando de "realidades que foram esquecidas ou negadas de forma insistente e obtusa pelo mundo moderno e, apesar disso, reaparecem agora com mais energia 27"”. Assim, Paz compreende a demanda do corpo, que volta ao mundo, mas é retida na opressão que, se não aniquila totalmente as explosões radicais da juventude, ao menos tardam o seu reaparecer - jamais projetado num futuro. Ou seja, ainda que as demandas juvenis sejam adiadas, de forma

\footnotetext{
${ }^{25}$ PAZ, Octavio. O Labirinto da Solidão. Trad. Ari Rotiman e Paulina Wacht. São Paulo: Cosac Naify, p. 217.

${ }^{26}$ Ibidem. p. 218.

${ }^{27}$ Ibidem. p. 235.
} 
nenhuma estas são retidas na projeção utópica que as deteriam no amanhã, pois "o futuro é um tempo falacioso que sempre nos diz "ainda não é a hora" e assim nos nega ${ }^{28 \prime \prime}$.

Ademais, esta crítica levará Paz a realizar uma de suas análises comparativas mais importantes: a crítica da Pirâmide. Para o escritor, o México pode ser compreendido como "um complexo de atitudes e estruturas inconscientes que, ao contrário de sobrevivências de um mundo extinto, são sobrevivências constitutivas de nossa cultura contemporânea ${ }^{29 \prime \prime}$. Em suma, a visão da história de Octavio Paz, compreendida como justaposta e tortuosa, revela a permanência de elementos invariantes, constituintes da cultura em atividade, porém, na maior parte das vezes, imperceptíveis, apesar de não serem invisíveis. Estes elementos presentes no interior da realidade mexicana se associam pela combinatória e, graças a esta perenidade, resistem ao julgo da própria história linear consecutiva, pois lhe impõem sua figura de resistência. Esta é a realidade, por exemplo, do mito. Por esta razão, Octavio Paz irá compreender os fatos ocorridos em dois de outubro de 1968 como um sacrifício ritual. O que se vê, portanto, é uma continuidade de uma das formas de dominação do poder asteca - através de sua instituição maior: a Pirâmide - exercendo seu mandato através de forma invisível, ou seja, através da imagem de mundo. Para Octavio Paz, esta é a forma como a pirâmide deve ser compreendida:

\footnotetext{
“tempo petrificado, os quatro lados da pirâmide representam os quatro sóis ou idades do mundo, e suas escadas são dias, meses, anos, séculos. Em cima, na plataforma: o lugar de nascimento do quinto sol, a era nahua e asteca. Uma construção feita de tempo: o que foi, o que será, o que está sendo ${ }^{30 \prime \prime}$.
}

Nesta mesma estrutura, a continuidade do tempo (isto é, o nascimento do novo sol) é garantido através do sacrifício: à medida em que se banha a pirâmide de sangue, o gérmen da vida passa a brotar, numa operação mítica de conjunção de opostos. No

\footnotetext{
28 Ibidem. p. 252.

${ }^{29}$ Ibidem. p. 256.

30 Ibidem. p. 260.
} 
interior do mito, os deuses jogam entre si: este é seu espaço de criação e destruição, cuja disjunção desconhecem. A destruição criadora dos deuses é dança e nela quem baila é o tempo e o mundo: estes surgem através destes ritos primordiais, divinos. Neste universo, o sacrifício é apenas mais um dos passos deste ritual festivo.

De forma similar, os astecas representavam politicamente o mundo celeste: a dança prosseguia à medida em que sacrificavam seus prisioneiros de guerra (política e cósmica). Este é o modelo ritual encarnado no Estado mexicano que, para Paz, permanece reproduzindo a antiga estrutura de poder: "a conexão entre os ritos religiosos e atos políticos desaparece, mas [...] o modelo inconsciente de poder continuou sendo o mesmo: a pirâmide e o sacrifício ${ }^{31 "}$. Para Paz, este fio invisível que se mantém entre uma sociedade e outra é o da dominação. Por mais transformações técnicas, ideológicas e culturais que o México tenha passado, suas antigas estruturas de dominação se mantiveram de forma velada, através de renovações em figuras diferentes, oriundas da Revolução. O processo revolucionário foi um dos momentos disruptivos da história do México que teve por ônus o endosso inconsciente da visão de mundo asteca e, com isto, tanto da pirâmide quanto da pedra ritual dos sacrifícios. 0 problema da interpretação que transforma a república mexicana em uma herdeira direta do Império Asteca é que ela incorre em um dos erros que nós ainda cometemos: estamos a ler a história sob a ótica dos vencedores. Para Paz, a história da mesoamérica incorpora ao mesmo tempo que oculta outras tradições e culturas que foram dizimadas, cuja dúvida nos cerca graças à antropologia e aos estudos da arqueologia. Por isso, diz que "a Mesoamérica não era uma pirâmide, mas uma assembleia de pirâmides ${ }^{32 " . ~ D e ~}$ toda forma, é preciso reconhecer que o período asteca possuía um lado obscuro e assombroso, assomado não apenas pelos sacrifícios, mas por toda sorte de sacrilégios que envolvem uma situação de dominação política e cultural, em suma, uma aberração da história: "o ano asteca era um círculo de dezoito meses encharcados de sangue; dezoito cerimônias, dezoito maneiras de morrer ${ }^{33 \prime \prime}$.

\footnotetext{
31 Ibidem. p. 262.

32 Ibidem. p. 265.

33 Ibidem. p. 267.
} 
Desta maneira, o espetáculo divino encarnou-se na Praça do Tlatelolco no massacre de 1968, que simbolizou a petrificação do tempo e de qualquer ameaça de transformação política através do sacrifício dos jovens estudantes. O Partido Revolucionário Institucional e seu mandatário soberano, o Presidente, como o "tatloani", o sacerdote hierarca que encarna o poder em si mesmo, amparado pela legalidade, torna-se herdeiro da casta asteca que governava toda a Mesoamérica. Em suma, "Tlatelolco se insere com uma lógica aterradora dentro da nossa história, a real e a simbólica. [...] É a contrapartida, em termos de sangue e sacrifício, da petrificação do $\left.\mathrm{PRI}\right|^{34 \prime}$.

Por fim, Octavio Paz finaliza sua crítica à principal instituição de conservação histórica do México, o Museu de Antropologia Nacional, que guarda seu principal monumento arqueológico: a Pedra de Sol. Nesta crítica, ele afirma que

\footnotetext{
"entrar no Museu de Antropologia é penetrar numa arquitetura feita com a matéria solene do mito. Há um imenso pátio retangular e nesse pátio, um grande guarda-sol de pedra pelo qual a água e a luz escorrem com um rumor de calendários quebrados, cântaros de séculos, e anos que se derramam sobre a pedra cinza e verde. O guarda-sol é sustentado por uma coluna alta que seria prodigiosa se não estivesse coberta de relevos com os motivos da retórica oficial. [...] Lá a antropologia e a história se colocaram a serviço de uma ideia da história do México, e essa ideia é o alicerce, a base enterrada e inabalável que sustenta nossas concepções do Estado, do poder político e da ordem social. [...] Nem é preciso dizer que, do ponto de vista da ciência e da história, a imagem do nosso passado que o Museu de Antropologia nos oferece do passado précolombiano é falsa ${ }^{35 "}$.
}

Portanto, esta visão idealizada do passado asteca empobrece a realidade histórica mexicana e endossa toda uma narrativa que, na visão de Octavio Paz, confirma a visão dos continuadores da relação de dominação que se manteve no México. Esta mitificação poupa, inclusive, os algozes de 1968, pois Ihes confere a legitimidade por meio da qual

\footnotetext{
34 Ibidem. p. 276.

35 Ibidem. p. 278.
} 
os governantes do México podem agir amparados pela legalidade autoritariamente instituída. Defronte a esta mitificação de sua história, o México só teria, então, uma opção: a crítica. Mas, para Paz, mesmo a crítica é capaz de, em muitas vezes, se embrenhar em seus próprios mitos, como nos mostrou o ocaso das visões progressivas da técnica moderna. Novamente, trata-se, então, de exortar a crítica imaginativa, a única capaz de nos oferecer uma visão não-alienada dos fatos, sem a eles se prender de forma cega e bruta. Talvez, no último parágrafo de $O$ Labirinto da Solidão, Paz nos dê a sua melhor definição do que é a crítica: "é o aprendizado da imaginação em sua segunda volta, a imaginação curada de fantasias e decidida a enfrentar a realidade do mundo ${ }^{36 "}$. A crítica disposta a dissolver seus próprios ídolos e, talvez, como nos indicam tanto Walter Benjamin quanto Marx, finalmente despertada do sonho de si mesma.

Diante de um universo cuja imagem de tempo se encontra "nublada", Paz propõe uma escuta ativa do mundo, a fim de redescobri-lo a partir destes fragmentos dispersos, alguns visíveis, outros invisíveis, como exemplificamos acima. Tal redescoberta encontrará em cada estilhaço uma estrela e em seu conjunto, uma constelação de ideias e imagens. Somente um tempo plural, aberto às mais variadas vivências, seria capaz de auxiliar na percepção desta nova imagem.

Por isso, a obra poética de Paz, desenvolvida concomitantemente aos ensaios, corresponde a uma galeria viva destas imagens. Por esta razão, analisaremos em nosso segundo itinerário três poemas de sua vasta bibliografia poética: Pedra de Sol, na tradução de Horácio Costa; Transblanco, na tradução de Blanco por Haroldo de Campos e, por fim; Noturno de San Ildefonso, também numa tradução de Costa. A distância que os separa permuta um período de, aproximadamente, dez anos cada. A análise dos três poemas, ainda que panorâmica, nos permitirá vislumbrar como a compreensão do instante poético, das figuras vivas da história, do mito e do amor se conjugam, conflitam e resolvem-se entre si. Talvez seja possível traçar um fio que constitua, neste universo alegórico aberto, uma série constelacional de ideias. A partir de nossa interpretação, pretendemos mostrar como o instante poético é o grande elemento em comum que conjuga não apenas os poemas entre si, mas também a obra ensaística de Octavio Paz à

\footnotetext{
${ }^{36}$ Ibidem. p. 279.
} 
sua obra poética. Em suma, sem mais delongas, nosso objetivo pode ser definido em: conquistar um entendimento deste princípio multifacetado que esteve presente durante toda a obra poética, crítica e política de Octavio Paz. É compreender em que consiste este presente puro, onde, como diz Paz em Libertad bajo palabra: "Todo desemboca en esta eternidad que no desemboca 37 ". Sem mais delongas, comecemos.

${ }^{37}$ PAZ, Octavio. Libertad bajo palabra: obra poética (1935 - 1957). México: Fondo de Cúltura Económica, 1995. p. 12 


\section{Itinerário ensaístico: formação do modelo epistemológico}

\section{Octavio Paz encontra o anjo da história}

Octavio Paz diz que, das coisas que pôde reter da obra e da vida de Sor Juana Inés de la Cruz, uma das principais, certamente, foi a de que em determinados momentos históricos em que se impõe uma proibição ao livre pensar, "com frequência o autor compartilha [deste] sistema de proibições - tácitas mas imperativas - que formam o código do dizível em cada época e em cada sociedade ${ }^{38 "}$. Durante esta obra, Sor Juana Inés de la cruz ou As armadilhas da fé, não será inconstante a comparação da situação social e histórica do México de Sor Juana com a de países pertencentes ao bloco soviético-socialista sem, no entanto, se perder de vista que nas ditas sociedades liberais há uma inflação de preferências e formas de percepção que funcionam, à sua maneira, como censoras da nossa sensibilidade, como fica explícito na passagem:

\footnotetext{
“Não é impossível que a popularidade de certos gêneros - a poesia, por exemplo [...] - resulte da censura implícita da sociedade democrática e progressista. O racionalismo burguês é, digamos assim, constitucionalmente contrário à poesia. Daí que a poesia, desde as origens da era moderna [...] tenha se manifestado como rebelião. Ela não é um gênero moderno; sua natureza profunda é hostil ou indiferente aos dogmas da modernidade: o progresso e a supervalorização do futuro ${ }^{39 \prime \prime}$.
}

Ou seja, mesmo que alguns poetas modernos encarnem este espírito evocado pelos dogmas da modernidade, aquilo que sua poesia diz ainda é outra coisa. Portanto, só será possível construir uma biografia justa acerca de Sor Juana se se levar em conta que "a compreensão de sua obra inclui compreender a proibição que essa obra enfrenta ${ }^{40 \prime}$. Podemos interpretar que a compreensão dos gestos de enfrentamento sutilmente sustentados por Sor Juana só é possível graças à postura do poeta moderno, para quem

\footnotetext{
${ }^{38}$ PAZ, Octavio. Sor Juana Inés de la Cruz ou As armadilhas da fé. Trad. Wladir Dupont. São Paulo: Ubu Editora, 2017. p. 15.

39 Ibidem. p. 14.

${ }^{40}$ Ibidem.
} 
a revolta figura como atitude imprescindível. Não obstante, Paz confronta visões que visam a sacralizar a monja poetisa, numa espécie de apagamento da complexidade que constituiu a sua vida. Neste sentido, resgatá-la no monastério é verificar como a admissão do mesmo nada mais é do que o reconhecimento das condições históricas pelas quais ela poderia se propor a agir com liberdade: dentro da igreja e, segundo Paz, encarnando no discurso figuras masculinas que, paradoxalmente, Ihe possibilitariam reconhecer e compreender a sua condição de mulher. Admitir o convento e a Igreja não significa fazer desta instituição o palco para o desenvolvimento de suas ideias, pois

\footnotetext{
"como era de se prever, a base filosófica que lastreava suas obras e especulações repousava menos na teologia ou na mundividência ortodoxamente católicas que em linhas de pensamento paralelas - que, como assinala Paz, através de operações sincréticas momento devidas aos jesuítas, penetravam ou tangenciavam o credo católico e assomavam ao corpus teológico de então - como o neoplatonismo e o hermetismo. Estes, como é sabido, haviam sofrido uma interação grande durante todo o renascimento e estavam em plena floração - que logo seria abortada pelo advento do racionalismo - na idade barroca ${ }^{41 "}$.
}

Para que pudesse compreender a monja mexicana, Paz teve de fazer uma incursão por todo o imaginário poético, político, religioso e científico do século XVII e da natureza cultural do Vice-Reinado da Nova Espanha.

Ademais, a partir desta compreensão, o biógrafo ou, simplesmente, o crítico, deve estar atento às entrelinhas, ao interdito, mas, sobretudo, ao que as palavras poéticas realmente nos dizem. Sor Juana Inés de la Cruz estava à frente de seu tempo, contudo, era prisioneira dele. Ainda que seus problemas com a Santa Sé não tivessem sido levados a cabo da forma mais dramática que muitos de seus contemporâneos sofreram - a fogueira -, a monja poetisa teve de se aferrar a este código dizível, garantindo-Ihe um arrefecimento dos riscos que seu livre pensar lhe incorria, através de

\footnotetext{
${ }^{41}$ COSTA, Horácio. Octavio Paz, biógrafo. São Paulo: Revistas USP Março/Abril e Maio, 1990. p. 144.
} 
uma censura assumida como voto de silêncio ao fim da vida ${ }^{42}$. Apesar disso, Paz reconhece que

\begin{abstract}
"não poucas vezes e quase sempre a despeito de si próprios, os escritores violam esse código e dizem o que não se pode dizer. O que eles e só eles têm de dizer. Por sua voz fala a outra voz: a voz condenada, sua verdadeira voz. Sor Juana não foi exceção. Ao contrário, seus contemporâneos logo perceberam, em sua voz, a irrupção da voz outra ${ }^{43 \prime \prime}$.
\end{abstract}

Contudo, ao reconhecer Sor Juana Inés de la Cruz como a sua outra voz, Octavio Paz dá luz à estranheza histórica que é marca de sua própria originalidade diante de seu tempo. Sua ponte com Sor Juana é um recorte sincrônico que possibilita o estabelecimento de uma série crítica (política, cultural e estética) que o joga impreterivelmente no presente junto com ela. Em suma, Paz reconhece que o que faz em relação à vida e obra da poetisa mexicana é um ensaio de restituição histórica, relativa e parcial. Assim, ao fazê-lo

\footnotetext{
“em sua tradução seiscentista, Paz indiretamente traduz-se a si próprio, nas não menos hieráticas cifras do seu meio mexicano contemporâneo [...]. Na biografia [...] assoma o perfil histórico de Paz: como Sorór, um espírito vasto demais para o seu contexto e que se percebe como tal, marcada por contradições embrionárias, experimental e inclusivo, e consciente de sua própria estranheza histórica ${ }^{44 \prime \prime}$.
}

Octavio Paz como biógrafo é um autor em constante exercício acerca de sua condição histórica e, sobretudo, temporal. Ainda assim, poderíamos questionar: Por que Sor Juana surge como a outra que interessa a Octavio Paz? Ora, a nosso ver, trata-se do

\footnotetext{
42 O que não impediu boa parte de seu reconhecimento em vida. O prestígio de Sor Juana Inés de la Cruz na corte provinha de seu talento, mas também do contato e proximidade com a condessa de Paredes, responsável por divulgar o seu trabalho na Espanha, na cidade de Sevilha.

${ }^{43}$ Ibidem. p. 15.

${ }^{44}$ COSTA, Horácio. O traduzir como necessidade e como projeto IN MACIEL, Maria Esther (Org.) A palavra inquieta: homenagem a Octavio Paz. Belo Horizonte: Autêntica, 1999. p. 34
} 
despertar de uma constelação de ideias à medida em que o texto de Sor Juana se apresenta não apenas pelas mãos de seu biógrafo, mas pela importância que possui em si mesmo, como um conjunto vivo de cifras de ideias e possibilidades.

No mais, se pudéssemos definir que espécie de constelação Paz viu na obra de Juana Inés, certamente definiríamos como uma constelação da lucidez, entendendo a lucidez como "esse olhar que vê o invisível trânsito entre o que é e deixa de ser, entre o que não é e chega a ser. [...] Se algo distingue a poesia de Sor Juana da dos outros poetas é uma clareza inteligente que logo se transforma em consciência ${ }^{45 \prime}$. Vital e estética, a lucidez é compreendida pelo autor como uma 'consciência melancólica', onde a imaginação é aberta ao espírito, segundo certo conceptismo barroco, a jogar com "palavras, imagens e conceitos". Pressupor que Paz se insere na esteira desta tradição não é desmesurado, uma vez que o mexicano também lança mão, em seu texto, de

\begin{abstract}
"paradoxos, tautologias, metáforas, aliterações, paronomásias [que] convivem com silogismos, conceitos, citações teóricas e termos científicos. O limite, assim, entre o que se espera de uma dissertação crítica (com seus critérios de objetividade, clareza e cientificidade) e o que compõe a linguagem de um poema fica impreciso: o texto é, simultaneamente, transitivo, à medida que informa, argumenta, relaciona, interpreta, e intransitivo, ao exibir sua própria textualidade como espetáculo ${ }^{4 \prime \prime}$.
\end{abstract}

Encontro que é possibilidade, como bem aponta Maria Esther Maciel, pelo gênero adotado pelo autor: o ensaio. A utilização do ensaio como ferramenta criativa, contrariando, inclusive, um dos teóricos do gênero, Theodor Adorno, condiz com a atividade poética e ininterrupta de Octavio Paz. Se, por um lado, Haroldo de Campos se refere à poesia de Octavio Paz como "constelação47", certo é que aquilo que o poeta

\footnotetext{
45 PAZ, Octavio. Sor Juana Inés de la Cruz ou As armadilhas da fé. Trad. Wladir Dupont. São Paulo: Ubu Editora, 2017. p. 566.

${ }^{46}$ MACIEL, Maria Esther. As Vertigens da Lucidez: poesia e crítica em Octavio Paz. São Paulo: Experimento, 1995. p. 65.

47 Cf. CAMPOS, Haroldo. Constelação para Octavio Paz In PAZ, Octavio. Os Signos em Rotação. Trad. Sebastião Uchoa Leite. São Paulo: Perspectiva, 2009. pp.299 - 313.
} 
constrói no plano das imagens através de seus "signos em rotação", também é certo que este plano possa ser vislumbrado na sua crítica teórica e nos seus ensaios, em geral.

A inserção de Sor Juana Inés de la Cruz nas referências constitutivas de Octavio Paz atende à construção de um repertório de obras que o poeta classifica como textos vivos. Na primeira frase da vasta biografia que escreve acerca da poetisa, o autor diz: “Na época em que comecei a escrever, por volta de 1930, a poesia de Sor Juana Inés de la Cruz deixara de ser relíquia histórica para se transformar em texto vivo ${ }^{48 \prime}$. Texto vivo é aquele que se insere na linha tortuosa que nos conecta a um passado fundador, cuja função é nos situar no emaranhado de tendências e construções estéticas dispersas pela história, consolidando um todo que se apresenta como sentido. Ora, precisamente aqui, a tradição que interessa a Paz é formada pela "persistência de uma forma de ver, sentir e pensar ${ }^{49 \prime \prime}$ intelectual e constelacional, voltada à construção crítica do conhecimento e ao exercício laborioso da imaginação poética em consonância com o espírito especulativo que marca boa parte da poesia contemporânea ao mexicano, sobretudo a sua. No caso, Paz realiza a conexão de sua tradição à de Juana Inés pensando na continuidade do poema cujas imagens não se voltam aos olhos, necessariamente, mas ao pensamento. Inclua-se nisto um detalhe extremamente significativo: esta tradição que Ihe liga a Sor Juana Inés de la Cruz passa rigorosamente por Mallarmé.

Entretanto, para que pudesse realizar este corte sincrônico, o trabalho de Octavio Paz no resgate da figura de Sor Juana Inés de la Cruz teve de passar por um processo de laicização de sua biografia. A razão disso é que "o antibarroco século XVIII relegou ao ostracismo toda a produção de Sor Juana [...] e apenas em 1873, com a publicação em Quito de Obras Selectas, tem início sua recuperação literária ${ }^{50 \prime \prime}$. O trunfo é que esta recuperação fez jus a um trabalho historiográfico que não idealizou uma figura nacional inspiradora da santidade. Ao longo dos anos, Sor Juana Inés de la Cruz foi instrumentalizada no interior de um discurso religioso que subjugou detalhes e particularidades significativas de sua biografia a um aspecto sacro de sua vida. A "santificação" de sua figura, por assim dizer, escamoteou a complexidade das questões

\footnotetext{
48 PAZ, Octavio. Ibidem. p. 9.

${ }^{49}$ Id. O Arco e a Lira. Trad. Ari Roitman e Paulina Wacht Trad. Sebastião Uchoa Leite. São Paulo: Perspectiva, 2009.. São Paulo: Cosac Naify, 2012. p. 255.

${ }^{50}$ COSTA, Horácio. Octavio Paz, biógrafo. São Paulo: Revistas USP Março/Abril e Maio, 1990. p. 144.
} 
que a monja enfrentou em vida, bem com os descaminhos de sua individualidade e suas questões pessoais (ainda que estas, de alguma forma, possam ser levantas apenas sob a ótica da especulação). Ao dessacralizá-la, Octavio Paz devolve-lhe a humanidade e tiraIhe do hall das figuras santas. Mais do que isto, Enrico Mario Santí nos recorda que, para Octavio Paz, a vida monástica atendia apenas a um desejo específico de Sor Juana: escrever e viver em contato com as grandes ideias. Da mesma forma, o biógrafo do poeta mexicano sugere que o fato de Paz ter se apaixonado pela obra da monja poetisa se deve à similaridade com que o poeta usufruiu de sua carreira diplomática, a qual lhe ofertava um constante contato com os livros e a pena. "A embaixada foi sua igreja", revela Santí em entrevista à TV PUC-Rio ${ }^{51}$. Em suma, por estas e outras razões, "não é difícil compreender que o livro de Paz seja também o resultado de uma intenção de desalienar esta figura fundacional da sociedade mexicana, expondo-a o mais possível à nossa compreensão ${ }^{52 "}$.

Em O Arco e a Lira, o poeta mexicano afirmará que o poema Un coup de dés pode ser encarado como um marco na poesia moderna, de modo a estabelecer um antes que se encerra como ele - e um depois, do qual ele é o princípio ou a abertura da pergunta a ser respondida pelos poetas em seus futuros versos. $O$ lance de dados mallarmaico é um poema intelectual, pensado, voltado sobre si mesmo porque compreende o mundo como texto: seu duplo. Em Os Signos em Rotação, um de seus mais importantes ensaios sobre poesia, Octavio Paz diz:

\footnotetext{
“A destruição foi minha Beatriz, diz Mallarmé em carta a um amigo; no final da viagem o poeta não contempla a Ideia, símbolo ou arquétipo do universo, mas um espaço em que desponta uma constelação: seu poema. Não é uma imagem nem uma essência; é uma conta em formação, um punhado de signos que se desenham, se desfazem e voltam a desenhar-se. Assim, este poema que nega a possibilidade de dizer algo absoluto, consagração da impotência da palavra,
}

\footnotetext{
${ }^{51}$ TV PUC-Rio. Paixão Crítica, Octavio Paz. 2015. Disponível em: https://youtu.be/ysxMMKaE4xQ (Acesso em 30 de Maio de 2019).

52 Ibidem.
} 
é ao mesmo tempo o arquétipo do poema futuro e a afirmação plena da soberania da palavra ${ }^{53 \prime}$.

A destruição mallarmaica é a abertura de uma série de possibilidades no campo da poesia. Ao colocar os signos sobre um plano intelectual, Mallarmé afirma que "tudo se passa, para resumir, em hipótese; evita-se o relato ${ }^{54 "}$. Ora, o que é, pois, a hipótese senão uma possibilidade, um vir a ser não-quantificado, não-experienciado, indicado por um dos versos primordiais do poema Um Lance de Dados: "Seja ${ }^{55 " ? ~}$

É justamente a este universo de possibilidades abertas que é licito atribuir o termo "constelação". A operação poética que Octavio Paz, biógrafo de Sor Juana, realiza pode ser compreendido como o ato de dimensionalizar a leitura como ato cósmico, conforme aponta Horácio Costa em Octavio Paz, biógrafo:

\footnotetext{
“Numa tirada de ressonâncias mallarmenianas, Paz compara as letras impressas na página com a projeção da esfera celeste entre as mãos daquele que lê - são leite astral destilado, suco da Via Láctea de que se embebe o leitor, no caso a jovem Juana. La leche primordial se transforma en vocabulario, el cielo estrellado en un lenguaje; las gotas de la leche estelar son silabas que escriben nuestro destino. [...] Aqui nos deparamos com uma tentativa mais básica de desalienação que nos toca em nossa identidade de leitores - a de revisão ontológica do próprio ato de ler ${ }^{56 \prime}$.
}

Esta leitura de Paz é possível graças à acuidade com que seu discurso, muitas vezes, toma a forma daquilo que expressa. Trata-se do procedimento caracterizado pelo seu "método" analógico, capaz de nos permeabilizar em nossa experiência de leitura.

Adiante, Paz acrescenta:

\footnotetext{
${ }^{53}$ Id. Os Signos em Rotação. Trad. Sebastião Uchoa Leite. São Paulo: Perspectiva, 2009. p. 113.

${ }^{54}$ MALLARMÉ, Stephan. Um lance de dados. Trad. Haroldo de Campos. In CAMPOS, Augusto (Org.). Mallarmé. São Paulo: Perspectiva, 2013. p. 151.

55 Ibidem. p. 156.

${ }^{56}$ COSTA, Horácio. Op. Cit. São Paulo: Revistas USP Março/Abril e Maio, 1990. p. 146.
} 


\begin{abstract}
"O horizonte em que aparece a constelação errante que formam os últimos versos de Un coup de dés é um espaço vazio. E a própria constelação além disso não tem existência certa: não é uma figura e sim a possibilidade de chegar a sêlo. Mallarmé não nos mostra nada exceto um lugar nulo e um tempo sem substância: uma transparência infinita. [...] 0 mundo como imagem, evaporouse. Toda a tentativa poética se reduz a fechar o punho para não deixar escapar esses dados que são o signo ambíguo da palavra talvez ${ }^{57 "}$.
\end{abstract}

"Talvez" que fora reconhecido no poema Primero sueño de Sor Juana pelo poeta. A ideia de constelação vincula-se à realidade do sonho, onde a profusão de imagens oníricas permite à possibilidade o seu emergir, tal qual uma imagem dialética. Ao comparar os poemas Un Coup de dés e Primero Sueño, Paz acaba por comparar duas imagens que estão presentes no início de cada poema: o abismo e a pirâmide, respectivamente. No caso do poema de Mallarmé, abismo onde quiçá se situa a nau que se lança, na sorte de um naufrago, rumo ao cosmo infinito, onde as estrelas também são signos linguísticos. De forma similar, Sor Juana tem a mesma sensação de vertigem, diante do mesmo cosmo, apesar deste não se mostrar a ela em sua infinitude, dado que o paradigma de seu tempo ainda era a finitude aristotélica-ptolomaica, apesar de todo o esoterismo e das doutrinas alheias ao cânone católico, como o hermetismo.

Porém, a vertigem provém da altura que se situa Sor Juana para lançar sua mirada sobre este mesmo cosmo: "Suspensa no alto de sua pirâmide mental feita de conceitos, a alma descobre que os caminhos que se abrem a sua frente são abismos e despenhadeiros sem fim ${ }^{58 "}$. A alocação de Sor Juana nesta esteira, que atinge Mallarmé, possibilita que Octavio Paz construa a sua constelação de ideias partindo de uma base sólida: da tradição barroca até o modernismo, passando por movimentos importantes, como o romantismo e o surrealismo (se quisermos resumir apenas o aspecto ocidental de suas influências). Novamente, compreendê-la como texto vivo, fazendo-a atravessar sincronicamente toda a diacronia histórica, para então presentificá-la, atende ao critério

\footnotetext{
${ }^{57}$ PAZ, Octavio. Ibidem.

${ }^{58}$ Id. Sor Juana Inés de la Cruz ou As armadilhas da fé. Trad. Wladir Dupont. São Paulo: Ubu Editora, 2017. p. 434.
} 
de utilizar a tradição como "modo criador 59 ", onde a vertigem da monja católica encontra seu correlato moderno no confronto de Mallarmé com a linguagem poética e seus símbolos. Se o francês abria o seu livro, texto do cosmo, para uma possibilidade infinda de variações poético-textuais, Sor Juana, observadora não mais de um espaço contemplativo, mas especulativo, ou seja, "diante de um espaço sem nome e sem limite ${ }^{60 "}$, abria-se diante do universo infinito do conhecimento:

\footnotetext{
“O poema de Sor Juana traz [...] o afã de conhecer, a ascensão da alma, sua queda vertiginosa e a penosa subida dos degraus do saber, um por um. Como poema de conhecimento não existe nada parecido até o surgimento de Un Coup de dés, que também termina em reticências: esse talvez que desenham, ao rodar pelo céu, as estrelas da constelação. [...] O protagonista de Un Coup de dés é o mesmo de Primero Sueño - o espírito humano, sem nome, história ou pátria, diante do céu estrelado. [...] Nesse sentido, Primero Sueño pertence à história da poesia universal ${ }^{61 "}$.
}

O ponto em comum destes dois poemas - Primero Sueño e Um Coup de dés - é que ambos terminam defronte a uma constelação (do alto da pirâmide ou do fundo do abismo) e, em ambos os casos, a resposta do/a poeta é o silêncio, evocado por um fracasso de ter, no acesso à revelação, o seu oposto: a não-revelação. Para Maria Esther Maciel, entretanto,

\footnotetext{
“paradoxalmente, essa insólita não-revelação é associada, pelo autor, a uma outra espécie de revelação: a consciência de que o fracasso é um saber. Consciência esta inerente ao pensamento moderno e que se faz de maneira radical no poema de Mallarmé. Daí ambos os poemas terminarem, segundo
}

\footnotetext{
${ }^{59}$ MACIEL, Maria Esther. As Vertigens da Lucidez: poesia e crítica em Octavio Paz. São Paulo: Experimento, 1995. p. 190.

60 PAZ, Octavio. Ibidem. p. 435.

61 Ibidem, p. 568.
} 
Paz, em pontos suspensivos, tendo como personagem invisível "o espírito humano, sem pátria, frente ao céu estrelado ${ }^{62 "}$.

A constelação torna-se o paradigma das duas obras poéticas e recebe, por conta disso, toda a importância na obra de Paz e no seu proceder metodológico em relação à própria história.

A história da poesia não deve ser encarada, aqui, como linear e progressiva, pois a concepção de história para Octavio Paz é a da justaposição e devemos compreender a sua leitura da tradição poética neste recorte temporal. Assim, o olhar historiográfico de Octavio Paz consegue encontrar os traços descontínuos e os instantes de justaposição presentes no interior da história mexicana. Ao pensar o papel da festa, Paz retorna à civilização espanhola para extrair daí a sua peculiaridade. Em As Armadilhas da Fé, o poeta diz que "a festa pública, secular ou religiosa, sempre ocupou lugar central tanto no calendário das nossas nações como na fantasia e sensibilidade de nossa gente ${ }^{63 "} .0$ tema da festa percorre várias obras de Octavio Paz e possui uma relevância a ser destacada ${ }^{64}$. Ao perscrutar as origens desta tradição tão enraizada no México e bastante presente no Vice-Reinado da Nova Espanha, Paz cunha que o caráter público da festa se trata, "sem dúvida, de uma característica pré-moderna, mais uma, ligada à relativa fraqueza de nossas burguesias: temos festas pela mesma razão que não tivemos lluminismo ${ }^{65 " .}$. Contudo, ainda que considere que esta assertiva verossímil, apesar generalista por submeter a realidade histórica da Espanha aos critérios de desenvolvimento evolucionista da dita "história universal", Paz considera que ela desconsidera uma série de particularidades importantes da história hispânica, singularidades de "uma história única e que nunca se ajusta inteiramente ao modelo europeu ${ }^{66 "}$. No mais, o fenômeno da festa como evento público se manteve. Paz diferenciará este evento do ocorrido na França, onde as festas perderam, paulatinamente, seu caráter público e se restringiram ao interior dos palácios, nas

\footnotetext{
${ }^{62}$ MACIEL, Maria Esther. Voo transverso: Poesia, Modernidade e Fim do Século XX. Rio de Janeiro: Sete Letras, 1999. p. 133.

63 Ibidem. p. 176.

${ }^{64}$ Adiante, trataremos da relação que este tema possui com a Revolta e com o Tempo.

65 Ibidem.

${ }^{66}$ Ibidem.
} 
cerimônias de cortesia, até a sua restauração - sangrenta - através da Revolução Francesa. Mas, no México, a função da festa sempre foi a da construção do Estado, função que, para Paz, permanece viva, a exemplo da cerimônia do Grito, realizada anualmente, em que os mexicanos, "dentro e fora do país, conduzidos pela voz presidencial, emocionados, repetem em coro, às onze da noite, o grito de independência “iViva México!" dado pelo padre Hidalgo em 1810, quando o país começa a se libertar do jugo espanhol67". Tal cerimônia colabora para a legitimação do Estado mexicano.

A partir deste breve relato acerca das festas e sua influência espanhola, Paz exporá duas correntes pelas quais se desdobraram as cerimônias hispânicas de entrada: a primeira, de origem popular e tradicional e a segunda, datada da importação borgonhesa. Octavio Paz aponta, através de suas leituras do estudo de Pierre Chaunu, L'Espagne de Charles Quint, que o imperador Carlos $\mathrm{V}$ teria importado os métodos administrativos e políticos do Ducado de Borgonha, do qual tivera influência em sua educação afrancesada. Nestes métodos, uma das festividades políticas era a joyeuse entrée, na qual se via a "expressão de um Estado mais forte e centralizado que o Estado castelhano68". Para Paz, estas manifestações e outras características do método administrativo foram registros embrionários do que viria a se tornar, posteriormente, 0 Estado absolutista. Desta forma, se pode compreender que a inserção da tradição festiva, através das Entradas, se deu na incorporação no Vice-Reinado de uma prática cujo exercício demonstrava o domínio simbólico do poder real. Portanto, esta questão historiográfica explica a questão estética que interessa a Paz, pelo menos em parte, acerca do predomínio no espírito mexicano do par trágico que o habita: "a festa e a obsessão pela morte. Duas formas trágicas do luxo e da dissipação que vêm de Borgonha69".

A constatação desta influência faz Paz, inclusive, questionar a visão predominante pela qual haveria nos povos hispânicos uma tendência ao barroquismo ${ }^{70}$, levantando a pergunta: como explicar a influência do Ducado de Borgonha, uma

\footnotetext{
67 Ibidem.

68 Ibidem. p. 177.

69 Ibidem.

${ }^{70} \mathrm{E}$ Paz o realiza tomando como referência não apenas o estudo já mencionado de Pierre Chaunu, mas também Huizinga e seu livro O outono da Idade Média: Estudos sobreas formas de vida e de pensamento dos séculos XIV e XV na França e nos países baixos.
} 
"civilização abortada", na arte e sensibilidade mexicanas? Em primeiro lugar, é preciso considerar que a própria formação do barroco partilhou de elementos que "talvez não [sejam] mais que uma expressão da subterrânea, mas viva corrente borgonhesa", ou seja, é possível compreender esta civilização como aquela que expressa o fim da Idade Média, seu outono. Em segundo lugar, Paz diz o motivo pelo qual a Espanha e, consequentemente, o México expressam esta continuidade é

\footnotetext{
"a anomalia da nossa evolução histórica e sua consequência: a superposição de diferentes tempos históricos e tipos de civilização. Nossa história não tem sido uma marcha, em nenhuma das acepções e variantes desta palavra - a linha reta dos evolucionistas, o zigue-zague dos dialéticos ou o círculo dos neoplatônicos. Nossa história tem sido um processo descontínuo feito de saltos por um súbito e violento despertar. Por vezes espanhóis e hispânicos esfregamos os olhos e nos perguntamos: que horas são na história real do mundo ${ }^{71 \prime}$ ?
}

O que Octavio Paz classifica como anomalia é apenas marca da expressão que melhor revela os acontecimentos distendidos no tempo e, por intermédio dele, mutáveis, intercambiáveis e suscetíveis a rupturas e despertares que são, muitas vezes, violentos. A ideia da justaposição histórica confronta a ideia de tempo linear e retilíneo, pois esta imagem de tempo anula particularidades (como a explicação da origem da festa no México), bem como as impossibilita de - uma vez adormecidas nas correntes da história - ressurgir de uma série subterrânea de fatos outrora desconhecidos.

Também é possível vislumbrar o fenômeno do sincretismo temporal do universo espiritual de Juana Inés através de duas figuras de extrema importância na cultura mexicana: a Virgem de Guadalupe e Tonantzin. Ao tratar do fenômeno da pluralidade temporal, Octavio Paz diz que

\footnotetext{
"a fuga dos deuses indígenas foi seu regresso com outros nomes. A conquista deixou as massas indígenas na orfandade espiritual. Essa situação de total vazio
}

\footnotetext{
71 Ibidem. p. 178.
} 
psíquico tornou possível sua conversão ao cristianismo: o batismo significava a possibilidade de pertencer à nova ordem religiosa, jurídica e política da nova Espanha. Ela abria não só as portas de ingresso na nova sociedade como as de regresso ao antigo mundo do sagrado. Os índios se tornaram cristãos; a divindade cristã e suas virgens e santos se indianizaram. Desde o princípio o cristianismo indígena foi um sincretismo popular e instintivo ${ }^{72 "}$.

Em suma, este fenômeno sacro foi a expressão de uma convergência que admitiu em seu interior duas temporalidades conflitantes, a linear e a cíclica. O processo de evangelização desempenhado pelos espanhóis teria sido impossível se, no interior de sua imposição doutrinária, não houvesse a resistência de uma sensibilidade religiosa anterior. A principal aparição que corresponde a esta realidade condicional da sociedade, que tinha em seu âmago o conflito entre criollos e mestiços, é a da Virgem de Guadalupe. Para Paz,

\footnotetext{
"nas circunstâncias da segunda metade do século XVII, a aparição da Virgem de Guadalupe, precisamente no santuário de uma deusa índia, confirmava o caráter único e singular da Nova Espanha. Um verdadeiro sinal, no sentido religioso com que se empregava essa palavra no século XVII, que insinuava uma conexão misteriosa entre o mundo pré-colombiano e o cristianismo. [...] A figura de Guadalupe/Tonantzin está gravada no coração do México e é impossível entender o país e sua história se não se entende o que foi e o que é tal culto ${ }^{73 \prime}$.
}

A correlação entre as duas divindades, à medida em que Tonantzin significava a maternidade terrestre, mãe e geradora do Cosmo, e a Virgem, sua encarnação na figura de uma Madona indígena, se deu graças à aparição da figura da Virgem no local dedicado ao culto da deusa, templo outrora ofertado à mãe asteca que, destruído durante a Conquista, fora edificado como uma capela para a santa católica. Coincidência mística, o espaço sacro abarcou, em seu ínterim, a transmutação de uma figura religiosa

\footnotetext{
72 Ibidem. p. 45.

73 Ibidem. p. 54.
} 
numa transformação da imagem de tempo cíclico-ritual na imagem de tempo linear e finita. Isto porque a Virgem de Guadalupe representava, por seu aspecto, a imposição de uma temporalidade alheia à vivida pela civilização asteca. Tais fatos, ocorridos no século XV, teriam transformado para sempre a história do México, mas, para Paz foi "o século criollo (XVII) que transformou a devoção à Virgem num culto nacional ${ }^{74 "}$. No mais, Octavio Paz enxerga a divindade católica e sincrética como o encontro das três culturas que constituem o México. Para ele,

\footnotetext{
“a Virgem é o ponto de união de criollos, índios e mestiços, e tem sido a resposta à tripla orfandade: a dos índios, porque Guadalupe/Tonantzin é a transfiguração de suas antigas divindades femininas; a dos criollos, porque sua aparição transformou a terra da Nova Espanha numa mãe mais real que a Espanha; e a dos mestiços, porque ela foi e é a reconciliação com sua origem e o fim de sua ilegitimidade ${ }^{75 \prime}$.
}

Octavio Paz aponta outras manifestações do sincretismo fundador do que viria a se tornar o México nos séculos subsequentes. No entanto, por uma razão que acreditamos ser de filiação, a figura da Virgem de Guadalupe/Tonantzin é a que melhor representa a convergência entre três culturas que se moldavam sob influência recíproca. Sob as luzes desta imagem, a civilização mexicana se projetou como um grandioso Império, cujas pretensões eram a durabilidade e a atemporalidade. Por mais que o cristianismo impusesse uma temporalidade sequencial e linear, a figura do reinado da Nova-Espanha deveria ser a da imutabilidade. A neoescolástica era uma reação ao tempo cristão convertido em marcha progressiva - tempo histórico. Neste sentido, o universo encastelado de Juana Inés, o convento, era para Paz uma fortaleza que estabelecia sua frente de batalha contra um inimigo implacável: a inevitável roda "do tempo ${ }^{76 " .}$

Em contraste a estas expectativas alimentadas no Vice-Reinado da Nova Espanha, a de referenciar o seu valor de perfeição no ideal de imobilidade diante da

\footnotetext{
74 Ibidem.

${ }^{75}$ Ibidem. p. 55.

76 Ibidem. p. 57.
} 
história, o mundo de Sor Juana era um mundo decadente. Para Paz, tratava-se de um mundo "pela metade", onde sua principal pensadora divagava entre ideias que já não frutificavam em cantos onde a liberdade de pensamento vicejava. Graças a estas amarras, o mundo de Sor Juana foi um mundo limitado, alheio às criações de Shakespeare, Racine, Milton, na poesia; além de "não ter informações sobre os

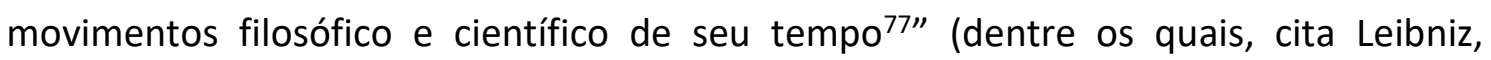
Espinosa e Newton). Quando os intelectuais da Nova Espanha entravam em contato com as novas ideias, estas estavam submetidas às amarras da ortodoxia teológica, único universo onde o reconhecimento de Juana Inés era unânime. Paz diz que

\footnotetext{
"entre as pessoas nascidas neste continente, Sor Juana Inés de la Cruz, uma das mais lúcidas, teve que viver entre ideias e livros envelhecidos. A escolástica desaparecia no horizonte e o neoplatonismo era uma novidade que já tinha dois séculos: a primeira era uma múmia, a outra, uma relíquia. [...] Seu texto mais comentado, causador de grande escândalo intelectual no México, Espanha e Portugal, a Carta Atenagórica, é um exercício sutil e vão. Hoje ilegível ${ }^{78 "}$.
}

O resultado da ortodoxia é a constante corrida atrás do bonde da história. Ainda que Paz o critique e considere que o país, assim como o continente latino-americano em geral, tenha em seu portfólio intelectuais que tentaram construir o pensamento de uma forma autônoma (e cita Benito Jerónimo, Sarmiento e Ortega y Gasset), insubmissa às ideologias exteriores, menos por um preciosismo de se ter um pensamento considerado "nacional", mas sim em se ter um pensamento voltado à sua própria identidade, no sentido de seu desenvolvimento histórico, "a geração seguinte, atordoada com esta ou aquela ideologia, volta a perder o bonde ${ }^{79 \prime}$. Insubmissão às ideias estrangeiras não significa desconectar-se delas, pois o que houve na Nova Espanha foi justamente isso: aniquilou-se a pluralidade de ideias em vista da imposição de uma única doutrina.

\footnotetext{
77 Ibidem. p. 304.

78 Ibidem.

79 Ibidem.
} 
Em suma, podemos inclusive afirmar que esta crítica de Paz traz no bojo um desconforto que já pertencia à tradição de pensadores e poetas modernos da península Ibérica. Quando Paz diz "Sofremos ainda os efeitos do Concílio de Trento"80" no encerramento do capítulo "Reino de Signos", ele aponta uma das causas que, para Antero de Quental, já eram responsáveis pela decadência dos povos peninsulares e, consequentemente, suas respectivas colônias. Em seu discurso intitulado, justamente, Causas da decadência dos povos peninsulares de 1871, Antero de Quental traça um período histórico - a linha dos séculos XVII, XVIII e XIX - em que a Península Ibérica "apresenta-nos um quadro de abatimento e insignificância, tanto mais sensível quanto contrasta dolorosamente com a grandeza, a importância e a originalidade do papel que desempenhamos no primeiro período da Renascença [e] durante toda Idade Média ${ }^{81 " .}$. Importância que era toda devida ao espírito de independência, do qual certamente não gozavam, de todo, as colônias, bem como do engenho e da inventividade. Em suma, todo o gênio popular, exaltado por Quental, é anulado pelo aprisionamento da Península a si mesma:

\footnotetext{
"Durante 200 anos de fecunda elaboração, reforma a Europa culta as ciências antigas, cria seis ou sete ciências novas, a anatomia, a fisiologia, a química, a mecânica celeste, o cálculo diferencial, a crítica histórica, a geologia: aparecem os Newton, os Descartes, os Bacon, os Leibniz, os Harvey, os Buffon, os Ducange, os Lavoisier, os Vico - onde está, entre os nomes destes e dos outros verdadeiros heróis da epopeia do pensamento, um nome espanhol ou português? Que nome espanhol ou português se liga à descoberta duma grande lei científica, dum sistema, dum facto capital? A Europa culta engrandeceu-se, nobilitou-se, subiu sobretudo pela ciência: foi sobretudo pela falta de ciência que nós descemos, que nos degradamos, que nos anulamos. A alma moderna morrera dentro em nós completamente ${ }^{82 "}$
}

\footnotetext{
${ }^{80}$ Ibidem.

${ }^{81}$ QUENTAL, Antero. Causas da decadência dos povos peninsulares. Lisboa: Ulmeiro, 1987. p. 14.

82 Ibidem. p. 27.
} 
Com base nesta questão, podemos afirmar que, se Juana Inés era prisioneira de seu tempo, somente a era não graças à rigidez jesuíta e católica do Vice-reinado da Nova Espanha, mas também graças à influência intelectual da metrópole, a ponto de esta significar, em alguns casos, sua única zona de liberdade, quando retém o bom recebimento de suas obras no velho continente. Antero de Quental diz que "a Inquisição pesava sobre as consciências como a abóbada dum cárcere ${ }^{83 \prime \prime}$, mas estas palavras poderiam ter sido facilmente desabafadas pela monja poetisa, consciente de sua condição limitante. O argumento de Quental acerca da causa da decadência dos reinos de Portugal e Espanha abarca três partes: em primeiro lugar, o argumento que afirma a importância da liberdade moral, impossibilitado nos reinados da Península, uma vez que seus respectivos mandatários de longe conferiam o exemplo necessário; em segundo, o engenho propiciado pelo desenvolvimento da indústria, vinculado à possibilidade de ascensão de uma classe média, a confrontar, economicamente, o poder absoluto, impondo-lhe restrições - o que, evidentemente, não se verificou nem em Portugal nem na Espanha e; por fim, em terceiro, as imposições oriundas do Concílio de Trento, que

\footnotetext{
"não inaugurou certamente no mundo o despotismo religioso: mas organizouo duma maneira completa, poderosa, formidável, e até então desconhecida. Neste sentido, pode dizer-se que o catolicismo, na sua forma definitiva, imobilizado e intolerante, data do século XVI ${ }^{84 "}$.
}

Diante da Reforma Protestante, o poder episcopal em Roma optara por "empedernir a Igreja, para a tornar inabalável ${ }^{85 "}$. O lamento de Quental assoma-se à decadência econômica das nações luso-espanholas, cuja correlação com a moralidade católica o autor apenas aponta, mas cuja explicação sociológica nos será oferecida por Max Weber em A Ética Protestante e o Espírito do Capitalismo, através de uma apreciação do desenvolvimento religioso da ética do trabalho. De toda forma, o século XVI moldou as

\footnotetext{
83 Ibidem. p. 28.

84 Ibidem. p. 32.

85 Ibidem. p. 35.
} 
condições políticas e intelectuais pelas quais Sor Juana Inés de la Cruz poderia ter desenvolvido seu pensamento, assim como a sua obra poética.

Portanto, o fato de Octavio Paz destacar a sua originalidade deve ser compreendido como um gesto poético de um autor que, por meio de uma visão historiográfica que, valendo-se da construção de uma biografia capaz de fazer vir à luz construções excepcionais para um contexto histórico-político limitante, demonstra não apenas a preocupação do leitor engajado na observação dos fatos disruptivos ao longo da história, mas a do autor preocupado em fundar, no seio de um mundo em que a esperança de liberdade parecia vedada, umas das origens intelectuais da tradição poética que reivindica como a sua, sinalizando os conflitos e as revoltas intelectuais, muitas das quais particulares, que faziam frente a este mundo opressor. Isto é, Octavio Paz "além de criar para si mesmo a sua precursora hispano-americana que, enquanto tal, nada fica devendo aos modernos poetas europeus, visto que o próprio autor a compara a eminentes da tradição da ruptura, como Mallarmé e Valéry ${ }^{86 "}$. Ao fazer isso, Paz também intenta demonstrar as manifestações originárias que visavam estabelecer um espírito nacional, mas que, inadvertidamente, acabavam por afirmar ideias fora de lugar e contexto ou mesmo sem possibilidade material e concreta de realização, tais como as que expõe no último capítulo da biografia da monja:

\footnotetext{
“É verdade que os jesuítas e os criollos haviam concebido um projeto vago, o Império Mexicano, transfiguração do espanhol e do asteca, mas essa concepção foi mais um sentimento que uma ideia. Como projeto só foi formulado até o início do século XIX - quando então já era, como a realidade bem demonstrou, inoperante. Foi preciso adaptar outro, trazido de fora [...] e imposto ao país como camisa de força. A sociedade novo-hispânica, que sobrevivera um século, morreu sufocada por essa camisa. Em seu lugar nasceu outra: a República do México. Essa é a origem, e uma das causas, da fragilidade de nossas instituições democráticas e das dificuldades que temos enfrentado para nos transformarmos em nação moderna ${ }^{87 \prime \prime . ~}$
}

\footnotetext{
${ }^{86}$ MACIEL, Maria Esther. Voo transverso: Poesia, Modernidade e Fim do Século XX. Rio de Janeiro: Sete Letras, 1999. p. 129.

${ }^{87}$ PAZ, Octavio. Ibidem. p. 558.
} 
Ou seja, mesmo em seu processo de modernização tecnológica, industrial e democrática, o México esteve operando sob a égide de ideias estrangeiras que, não obstante, não levavam em conta a particularidade local, tampouco os elementos originários do continente latino-americano que poderiam, à sua maneira, construir uma nação soberana - status político desafiador a qualquer país latino-americano. No caso mexicano, a ideologia que veio a calhar durante o século XIX foi a do positivismo, cuja visão linear progressiva da história e do tempo viera a se chocar com as formas originárias que, anteriormente, conviviam em gradual transmutação através do regime sincrético que se instalara na Nova Espanha, até então. Em suma, podemos afirmar que Paz denuncia uma relação em que o México subordinou-se às ideias europeias, incluindo-as de forma errônea em sua formação, o que culminou numa série de problemas históricos, se assim podemos dizer. De forma comparativa, podemos afirmar que o México, enquanto país latino-americano, obteve no século XIX uma postura similar à do Brasil, que, como aponta Roberto Schwarz

\footnotetext{
"ao longo de sua reprodução social, incansavelmente, põe e repõe ideias europeias, sempre em sentido impróprio. [E] é nesta qualidade que elas serão matéria e problema para a literatura. O escritor pode não saber disso, nem precisa, para usá-las. Mas só alcança a ressonância profunda e afinada caso lhes sinta, registre e desdobre - ou evite - o descentramento e a desafinação ${ }^{88 \prime \prime}$.
}

No episódio histórico brasileiro, as discrepâncias ressonantes à ideologia liberal, também associada à positivista; no mexicano, a falta de encaixe da visão de mundo positivista num país cuja formação, conforme bem mostrou Paz, é mestiça e plural.

Em Paz, o olhar teórico, consciente de sua tradição, presente nas suas análises sobre as diversas correntes poéticas e períodos históricos, foi assinalado por Haroldo de Campos em Poesia e Modernidade: da morte da arte à constelação - o poema pós-

\footnotetext{
${ }^{88}$ SCHWARZ, Roberto. As ideias fora de lugar In Ao vencedor as batatas. São Paulo: Duas Cidades - 34, 1992. p. 15.
} 
utópico. Nesta obra, Haroldo afirma que o poeta mexicano pensa sob uma forma sincrônica, o que torna inteligível as continuidades que as diferenças entre correntes e tradições, aparentemente opostas e conflitantes entre si, costumam ofuscar. Esta perspectiva de Paz é a de uma poética situada, "engajada no fazer de uma determinada época ${ }^{89 \prime}$. Em suma, para o crítico e poeta brasileiro, as suas análises são permeadas por um ponto de vista, onde há uma

\begin{abstract}
"apropriação seletiva e não consecutiva da história. Reconstrução do passado: porém não segundo os sucessivos quadros epocais, que a recapitulação das etapas da consciência estética permitia, ansiada maneira a mais "objetiva" possível, perfilar no eixo diacrônico; mas sim, enquanto tentativa de suscitar uma "imagem dialética" (W. Benjamin), capaz de recuperar, para utilidade imediata de um fazer poético situado na "agoridade", o momento de ruptura em que um determinado presente (o nosso) se reinventa ao se reconhecer na eleição de um determinado passado. Descoberta (participação) de um particípio passado que se comensure ao nosso particípio presente ${ }^{90 \prime \prime}$.
\end{abstract}

Ainda que Paz tenha tornado objeto de suas análises boa parte dos movimentos de vanguarda, seu pensamento é permeado por uma sensibilidade que, como afirma em $O$ Arco e a Lira é marca de uma sensibilidade persistente. Como já indicamos, um impulso humano que está presente tanto no pensamento romântico como no surrealista.

Engajar-se no fazer de uma determinada época postula uma relação crítica com a tradição que se estabelecera previamente. A crítica de Paz se dá, sobretudo, à ideia de progresso e para explorarmos a sua crítica contemporânea, utilizaremos o autor que, no interior da tradição filosófica, melhor representa esta postura e perspectiva: Walter Benjamin. Crítico do progresso, Benjamin também se preocupa em construir uma filosofia do tempo à luz de uma visão da história. A nosso ver, Benjamin se insere na tradição filosófica que se propôs a tratar do tempo como uma questão primordial: a mesma tradição que tem Platão, Agostinho, Kant e Bergson. Leitor de duas tradições

\footnotetext{
${ }^{89}$ CAMPOS, Haroldo. Poesia e modernidade: da morte da arte à constelação. O poema pós utópico. In O arco íris branco. São Paulo. Imago. 1997. p. 243.

90 Ibidem. p. 249.
} 
que longamente contribuíram para o desenvolvimento desta questão, a idealista e a materialista, Benjamin tentará extrair uma nova visão da temporalidade através de seu conceito de História. Contudo, como mostraremos abaixo, há também na concepção benjaminiana um recurso às imagens, cuja operacionalidade no interior de sua "filosofia do tempo" é fundamental. Estas concentram em si uma potencialidade que é capaz de interromper o fluxo contínuo do tempo histórico, tal qual a poesia de Paz nos mostra. Não por menos, muitas imagens benjaminianas são imagens poéticas, alegóricas, porque oriundas do sonho, do passado imemorial e do inconsciente de uma sociedade.

Por isso, importa a Walter Benjamin pensar as imagens que revelam um potencial disruptivo ou, simplesmente, a possibilidade de despertarmos junto a uma narrativa que há muito não se imiscuía em nossa atenção. Para Willi Bolle, em Fisionomia da metrópole moderna, em Benjamin,

\footnotetext{
"genericamente falando, [há] uma espécie de "especulação" das imagens, no sentido etimológico da palavra: um exame minucioso de imagens prenhes de história. Ela tem sua razão-de-ser na especificidade do seu pensamento, que se articula não tanto por meio de conceitos e sim de imagens. A "imagem" é a categoria central da teoria benjaminiana da cultura: "alegoria", "imagem arcaica”, "imagem de desejo", "fantasmagoria”, "imagem onírica”, "imagem de pensamento", "imagem dialética" - com esses termos se deixa circunscrever em boa parte a historiografia benjaminiana ${ }^{911}$.
}

Ou seja, aquelas imagens que no toque do olhar já trazem no bojo uma multiplicidade de eventos que, como pulsões, nunca foram sublimados ou realizados, mas apenas reprimidos. Estas imagens, múltiplas, diversas, plurais, são como um raio de luz que é introduzido no interior de um caleidoscópio, pois se desmembram em várias cores, tonalidades e segmentos: caminhos descontínuos do como se da história, sempre aberta. Podemos afirmar, em comparação, que Octavio Paz também reconheceu a potencialidade destas imagens oníricas, uma vez que tivera influência direta do grupo

\footnotetext{
${ }^{91}$ BOLLE, Willie. Fisionomia da metrópole moderna. São Paulo: Edusp. 2000, p. 42
} 
surrealista. Em seu ensaio dedicado ao tema, A estrela de três pontas: o surrealismo, Paz nos diz que

\footnotetext{
"as imagens do sonho proporcionam certos arquétipos para essa subversão da realidade. E não apenas as do sonho; outros estados análogos, desde a loucura até o devaneio diurno, provocam rupturas e rearranjos do real. [...] Seu propósito é subversivo: abolir esta realidade que uma civilização vacilante nos impôs como a única verdadeira ${ }^{92 "}$.
}

As imagens oníricas são imagens de ruptura, uma vez que não se coadunam ao ritmo imposto ao cotidiano e ao trabalho. Por isto, esta é a razão pela qual o sonho, assim como o sono, figura como o último bastião de resistência à potência colonizadora do capitalismo.

Para Jonathan Crary, em 24/7, vivemos um processo de constante ameaça de uma completa identificação do mundo para consigo mesmo, isto é, um processo em que toda a pluralidade existente se homogeneizaria num ritmo constante, invariável e regular, cuja maior característica seria a da vigência da luminosidade, ou seja, da ausência de sombras, das obscuridades e dos regimes de temporalidade distintas ou alternativas. Neste mundo, o ritmo resume-se ao trabalho e sua constância periga invadir o sono que, não obstante, se detém, como um reservatório imagético de um universo que sofre as duras consequências de um processo de empobrecimento sensorial, devido à elevada carga de impulsos luminosos cada vez mais universalizados graças aos nossos smartphones. Neste sentido, Crary afirma que o próprio "despertar"

- "perturbação epifânica da insipidez entorpecida da existência rotineira recupera autenticidade em oposição ao ócio entorpecido do sono. Nesse sentido, ele é uma forma de decisionismo: a experiência de um momento redentor que parece interromper o tempo histórico, no qual um indivíduo se

\footnotetext{
${ }^{92}$ PAZ, Octavio. A estrela de três pontas: o surrealismo In A busca do presente. Trad. Eduardo Jardim. Rio de Janeiro: Bazar do tempo, 2017. p. 48.
} 
submete a um encontro transformador com um futuro até então desconhecido ${ }^{93 \prime \prime}$.

Contudo, a própria metáfora, assim como a imagem do "despertar" - tão importante para Benjamin, como se verá - só possuirá sentido para uma sociedade que realiza o banal ato de... dormir. Porém, para Crary, a metáfora socrática - a de que devemos buscar pela "permanente luz diurna da razão" se torna a promessa convertida em armadilha da tecnologia moderna. Ainda que o norte-americano não o cite nesta passagem, parece aludir à armadilha que O'Brian faz a Winston em 1984 de George Orwell ao fazer a promessa de que "tornaremos a nos encontrar onde não há treva", onde, na realidade, descrevia uma sala de tortura onde as luzes jamais são apagadas.

Entretanto, nem neste horizonte desolador o sono, assim como o aspecto lúdico de nossa existência, deixa de oferecer resistência: a insanidade, a loucura, as fantasmagorias, a alucinação, em suma, a perda da razão, indicam que somos seres cuja imaginação opera, muitas vezes, de forma inconsequente, imprevisível e segundo ritmos próprios. Segundo o norte-americano, "paradoxalmente, para a subjetividade o sono é uma imagem sobre a qual o poder opera com a menor resistência possível de ser instrumentalizada ou externamente controlada ${ }^{94 "}$. Por isso, Jonathan Crary reconhecerá a importante contribuição de autores como Blanchot, Merleau-Ponty e Walter Benjamin acerca da compreensão da natureza complexa do sono e de suas imagens, que não se reduzem a simples esquemas binários nem se submetem a ordenamentos advindos de um universo que, ao que nos indica o filósofo, jamais poderá subjugá-lo de todo.

Quanto à iconografia onírica, a proposta benjaminiana é a de construir uma historiografia a partir destas imagens, cujo sentido aponta para a dialética, o sonho, o arquétipo, o mito e a alegoria. Seu campo de ação é a metrópole moderna que, soterrando potencialidades, não consegue apagar de todo as manifestações de um passado que, tal como um desejo reprimido no sonho, insiste em abalar as estruturas do que tomamos por real. Ainda que, muitas vezes, a diferença entre o sonho e a vigília

\footnotetext{
${ }^{93}$ CRARY, Jonathan. 24/7: capitalismo e fins do sono. Trad. Joaquim Toledo Jr. São Paulo: Ubu editora, 2016. p. 33.

94 Ibidem. p. 34.
} 
se esmoreça, tal como reconhecera Descartes em suas Meditações Metafísicas, podemos afirmar que o sonho abarca um outro tipo de experiência temporal. O universo onírico é permeado por imagens e possui um ritmo que não é o da necessidade e o da urgência cotidianas. No entanto, nem todos os sonhos significam um escape à dominação pela qual o mundo está submetido. Walter Benjamin cita Karl Marx na epígrafe de um dos capítulos do seu projeto de maior envergadura, a obra Passagens: "a reforma da consciência consiste apenas em despertar o mundo... do sonho de si mesmo ${ }^{95 " .}$. Esta questão toca na necessidade de reconhecermos o conteúdo do sonho que se realiza no interior de uma sociedade capitalista, produtora de imagens e aglutinadora de tudo o que move os nossos afetos e desejos. Ora, quando um sonho reproduz os sonhos que devem ser sonhados, segundo certa visão consumista da sociedade, onde ele contradiz a vigília - universo que lhe deveria fazer fronte? Sobre este ponto, Coetzee em As maravilhas de Walter Benjamin diz que:

\footnotetext{
"Segundo Max Weber, o que marca o mundo moderno é a perda da crença, o desencantamento. Benjamin tem um ângulo diferente: o capitalismo pôs as pessoas para dormir, e elas só despertarão de seu encantamento coletivo quando forem levadas a entender o que lhes aconteceu. [...] Os sonhos da era capitalista estão corporificados nas mercadorias. Estas, em seu conjunto, constituem uma fantasmagoria, constantemente mudando de forma de acordo com as marés da moda oferecidas a multidões de idólatras encantados com a corporificação de seus desejos profundos ${ }^{96 \prime \prime}$
}

De forma similar, Octavio Paz apontará o caráter religioso do mundo moderno. Em Conjunções e Disjunções, o poeta dirá que o processo de desencantamento do mundo segue como projeto de dominação do mesmo:

\footnotetext{
95 BENJAMIN, Walter. Passagens. Org e trad. Willi Bolle. São Paulo. Imprensa Oficial/ Ed. UFMG. 2009. p. 499.

${ }^{96}$ COETZEE, John Maxwell. As maravilhas de Walter Benjamin. Trad. José Rubens Siqueira. Revista Novos Estudos, no 70. 2004. p. 110.
} 
“A conquista, dominação e conversão da natureza tem raízes teológicas, embora os que hoje a empreendam sejam homens de ciência a-religiosos e mesmo ateus. A sociedade contemporânea deixou de ser cristã mas suas paixões são as do cristianismo. Apesar de nossa ciência e de nossa técnica não serem religiosas, possuem uma índole cristã: inspira-as o furor pio dos cruzados e dos conquistadores, dirigido agora não mais à conquista das almas mas à do $\operatorname{cosmos}^{97 \prime \prime}$.

Essa dominação inclui também qualquer tipo de concepção autônoma que façamos do mundo e do universo, em razão do 'solipsismo cientifico'. O processo de racionalização presente no interior da ciência, para além disso, correlaciona-se com o desenvolvimento do capitalismo. E, sobre este, é preciso ter em mente que o capitalismo, como uma doutrina religiosa universalista, se apropria do universo dos sonhos e os dispõe a seu favor. A indústria cultural é um grande exemplo de como potencialidades idílicas, outrora oriundas de obras de arte - como as do próprio surrealismo - acabam por converter-se em esquetes e estratégias de propaganda e marketing de grandes empresas. No entanto, convém apontar que uma diferenciação se faz necessária: se o capitalismo preenche o seu universo com imagens advindas do sonho, ele o faz sob a forma da fantasmagoria e não da ideia. A fantasmagoria distingue-se da ideia, pois mantém inócua e oculta a sua origem, enquanto a ideia permite a sua revelação, quando, não obstante, muitas vezes a expressa. Neste sentido, a fantasmagoria se manifesta como engrenagem da ideologia que, no sentido que a emprega Marx, opera na sociedade como véu que encobre, tal qual um invólucro, o real, a fim de mascarar a contradição entre o sistema de produção e os seus meios sociais. Como uma miragem, a fantasmagoria age rumo à alienação do ser humano. A ideia, entretanto, pode ser expressada através de uma imagem que consiga retirar o sonho da ordem de produção e consumo.

Dentre os sonhos que irrompem nas metrópoles, existem aqueles para quem as imagens oníricas aparecem como rupturas do continuum da vivência coletiva. Por vivência, Benjamin entende a espécie de situação onde nossa experiência passa por um

\footnotetext{
${ }^{97}$ PAZ, Octavio. Conjunções e Disjunções. Trad. Lucia Teixeira Wisnik. São Paulo: Perspectiva, 1979. p. 105.
} 
empobrecimento e atrofia. Ou seja, temos, por um lado, a experiência - "real ou acumulada, sem intervenção da consciência" - e, por outro, a vivência - experiência vivida, evento assistido pela consciência" - contrapostas uma à outra. Sobre esta distinção, ajuda-nos a explicação de Leandro Konder:

\begin{abstract}
"Erfahrung98 (experiência) é o conhecimento obtido através de uma experiência que se acumula, que se prolonga, que se desdobra, como numa viagem; o sujeito integrado numa comunidade dispõe de critérios que the permitem ir sedimentando as coisas com o tempo. Erlebnis é a vivência do indivíduo privado, isolado, é a impressão forte, que precisa ser assimilada às pressas, que produz efeitos imediatos ${ }^{991}$.
\end{abstract}

Pensando esta questão a partir da nossa capacidade de acumular a experiência concreta na memória, cujo arcabouço, no entanto, está longe de permitir uma acessibilidade facilitada, chegamos à constatação de que o papel da atenção consciente deve ser limitado. A tarefa do historiador é um trabalho árduo de percepção do que não está evidente, tal como o ofício do psicanalista, em que o papel da atenção voltada às imagens que afluem apenas as afunda invés de fazê-las emergir. Existe, porém, uma confluência entre o papel do paciente e o do analista que, silenciosamente, "auxilia" no processo terapêutico de associação livre das imagens. Assim como na psicanálise, na análise histórica temos a necessidade de resgatar as imagens através da mémoire involontaire, de fazê-las vicejar no presente, porém, de forma a permitir nelas a intrusão da crítica, a fim de distinguir nas imagens oníricas o que é fantasmagoria do que não é. Ora, este procedimento analítico se faz necessário, visto que estas imagens estão diluídas no limiar que se apresenta como real. Trata-se, então, de elucidar conteúdos

\footnotetext{
98 Sentido consonante ao expresso por Jeanne Marie Gagnebin em "Não contar mais": "a palavra Erfahrung vem do radical fahr - usado ainda no antigo alemão no seu sentido literal de percorrer, de atravessar uma região durante uma viagem. Na fonte da verdadeira transmissão da experiência, na fonte da narração tradicional há, portanto, esta autoridade que não é devida a uma sabedoria particular, mas que circunscreve o mais pobre homem na hora de sua morte, escreve Benjamin no parágrafo $X$ de "O narrador" (GAGNEBIN, Jean Marie. História e narração em Walter Benjamin. São Paulo: Perspectiva, 2007. P.58.)

${ }^{99}$ BENJAMIN, Walter. Sobre alguns temas em Baudelaire In Charles Baudelaire, um lírico no auge do capitalismo. Trad. José Carlos Martins Barbosa e Hemerson Alves Batista. São Paulo. Brasiliense. 1994. p. 146.
} 
oriundos do inconsciente. Porém, antes é preciso saber como se dá a ruptura no interior do continuum da nossa vivência, aquebrantado pela revelação espontânea das imagens.

Esta 'revelação', passível de ser compreendida como "retorno das almas para conosco", segundo a acepção proustiana do mito celta, não passa pelo crivo da intencionalidade consciente, pois ela só é possível graças à mémoire involontaire. Para Proust, este tipo de memória nos coloca num grau significativo de afastamento da memória atenta, graças à sua diferença qualitativa. Segundo sua definição, Marcel Proust afirma, distinguindo-as que

\footnotetext{
“a memória voluntária, que é sobretudo uma memória da inteligência e dos olhos, não nos dá, do passado, mais do que faces sem realidade; mas se um cheiro, um sabor encontrados em algumas circunstâncias totalmente diferentes, despertam em nós, à nossa revelia, o passado, passamos a sentir o quanto este passado era diferente daquilo que acreditávamos lembrar, e que nossa memória voluntária pintava, como os maus pintores, com cores sem realidade ${ }^{100 \prime \prime}$.
}

Portanto, há uma relação inversa entre durabilidade, intensidade e nível de consciência da memória experimentada. Geralmente, quando conseguimos acessar as memórias mais longínquas ou aquelas que se encontravam reprimidas em nosso íntimo, fazemolo porque nossa consciência se encontrava adormecida. Nestes momentos de desatenção, aéreos, as memórias involuntárias vêm à tona, como se dependessem da diminuição da densidade consciente do nosso "eu".

Em Sobre alguns temas em Baudelaire, Walter Benjamin explora esta questão, partindo de uma citação de Freud:

\footnotetext{
"Resíduos mnemônicos são, por sua vez, "frequentemente mais intensos e duradouros, se o processo que os imprime jamais chega ao consciente".
}

100 PROUST, Marcel. Em Busca do tempo perdido. V.1. No caminho de Swann. Trad. Mário Quintana. São Paulo. Ed. Globo. 2006. p. 511. 
Traduzido em termos proustianos: só se pode tornar componente da mémoire involontaire aquilo que não foi expressa e conscientemente "vivenciado", aquilo que não sucedeu ao sujeito como "vivencia". Segundo Freud, a função de acumular "traços permanentes como fundamento da memória" em processos estimuladores está reservada a "outros sistemas", que devem ser entendidos como diversos da consciência. Ainda segundo Freud, o consciente como tal não registraria absolutamente nenhum traço mnemônico. Teria, isto sim, outra função importante, a de agir como proteção contra estímulos ${ }^{101 "}$.

A técnica mnemônica é um procedimento que o próprio Baudelaire valoriza em $O$ Pintor da Vida Moderna, uma vez que em sua análise dos croquis de Constatin Guys, o poeta considera que seu conteúdo de elaboração finita expressa a imagem da modernidade ${ }^{102}$. Nas Passagens, Walter Benjamin afirma, num dos trechos do Arquivo $N$, que a razão deve possuir um sentido ativo na interpretação das imagens, impossibilitando que sobre elas o mito e seu conteúdo de desvario potencial possa predominar ${ }^{103}$. Há, portanto, uma necessidade de se aplicar a razão crítica a tudo o que surge enquanto imagem. Devemos considerar que manifestações retrógradas e de cunho totalitário como o fascismo se valem, justamente, de imagens arcaicas e míticas que já contém em seu interior o impulso dominador do esclarecimento (como ficou claro sob a ótica de Adorno e Horkheimer ${ }^{104}$ ) e o potencial destrutivo de tudo o que lhe é adverso, periférico, externo ao corpo orgânico massificado. Apenas uma crítica situada na historicidade pode lhes apontar o grau de desvario ao qual estão submetidas tais imagens, a fim de desmistificá-las e combatê-las, examinando, outrossim, seu caráter político e seu potencial libertador ou dominador. O local, da razão, neste pensamento só pode ser a crítica.

A questão que surge é: independentemente de seu conteúdo, é necessário possibilitar o resgate de um sonho, mesmo aquele repleto de imagens negativas,

\footnotetext{
${ }^{101}$ BENJAMIN, Walter. Ibidem. p. 108.

102 Ademais, para Baudelaire, o conteúdo das obras do pintor francês expressa um prazer diretamente ligado ao presente, por apresentar a sua "qualidade essencial de presente" (BAUDELAIRE, Charles. $O$ pintor da vida moderna. Trad. Tadeu Tomaz. Belo Horizonte: Autêntica Editora, 2010. p. 14).

${ }^{103}$ BENJAMIN, Walter. Passagens. Trad. Willi Bolle. São Paulo: Imprensa Oficial/ Ed. UFMG. 2009. p. 499.

${ }^{104}$ Cf. ADORNO, T; HORKHEIMER, M. A dialética do esclarecimento. Trad. Guido Antonio de Almeida. Rio de Janeiro. Zahar. 2006.
} 
capazes de pôr a risco os potenciais emancipatórios da humanidade? Segundo a visão historiográfica de Benjamin, sim. Pois, como afirmamos, o despertar pode trazer à tona ideias e, se não as trouxer, as imagens negativas podem ser destruídas pelo crivo da razão. Esta é uma forma de positivar toda imagem negativa no interior de uma crítica dialética. Mas isso depende de uma situação que revela a forma como Benjamin situa o tempo no interior do desenvolvimento histórico, trata-se da perspectiva do "tempo-doagora" (Jetztzeit). Trata-se de um momento-chave, oportuno, em que um determinado sujeito pode se apoderar do conhecimento - novo - sobre um determinado momento histórico capaz de ressignificar o presente. O modelo epistemológico de Walter Benjamin nos oferece uma visão da histórica que culmina numa imagem de tempo que vale a pena explorar, dada a similaridade e a correspondência ao método adotado por Octavio Paz ao estabelecer, em suas análises e interpretações, de forma seletiva, os conteúdos sensíveis capazes de transformar a sensibilidade e o próprio pensamento de seu tempo na espontaneidade do instante. O modelo que Haroldo de Campos considera avaliação sincrônica é, portanto, uma leitura da história a contrapelo.

Assim como para Octavio Paz, para Walter Benjamin, a concepção de tempo deve estar alinhada à possibilidade do vir a ser histórico enquanto descontinuidade. Por isso, o alemão fará uma crítica à concepção de Duração, pois esta concepção exclui a possibilidade do jogo imprevisível das rupturas e do acolhimento de determinadas tradições. Para o alemão,

a contagem do tempo, que sobrepõe a durée a sua uniformidade, não pode contudo evitar que nela persistam a existência de fragmentos desiguais e privilegiados. Legitimar a união de uma qualidade à medição da quantidade foi obra dos calendários que, por meio dos feriados, como que deixavam ao rememorar um espaço vago. [...] Se no Spleen e na Vida Anterior, Baudelaire ainda dispõe dos estilhaços da verdadeira experiência histórica, Bergson, por sua vez, em sua concepção da durée, se afastou consideravelmente da história. "O metafísico Bergson suprime a morte". O fato de a morte ser eliminada da durée de Bergson isola a durée da ordem histórica (bem como de uma prérica). 
[...] A durée, da qual a morte foi eliminada, tem a mísera eternidade de um arabesco; exclui a possibilidade de acolher a tradição ${ }^{105 "}$ (negrito nosso).

A crítica benjaminiana incide sobre o isolamento da durée em relação à história. 0 afastamento desta concepção de tempo da realidade histórica concreta afeta seu sentido por torná-la incapaz de reconhecer que, no interior de sua própria lógica, o tempo histórico admite interrupções. A Walter Benjamin interessa o fragmentário que, como veremos, é elucidado em Paz como a própria imagem da história. Estes fragmentos não são apenas os da história, pois como colocado por Proust, anteriormente, eles podem ser também os da memória involuntária, cuja realização depende daquilo que nos aviva exteriormente e estimula sensações e experiências subterrâneas em nossa trajetória, bem como volta nosso rosto para fatos não-vistos, figuras desapercebidas, textos cuja importância nos toca mais diretamente hoje e ideias descartadas capazes de se tornar a "pedra angular" de uma nova série histórica. Portanto, a possibilidade ínfima de possuirmos um ponto de inflexão na lógica histórica que seja capaz de frear o tempo, interrompê-lo bruscamente, é um pressuposto básico da visão que Benjamin constrói do tempo histórico. No mais, "a ideia de mudança isolada e eternizada é tão estática e abstrata quanto qualquer conceito hipostasiado ${ }^{106 "}$.

No trecho que citamos, o autor coloca em termos importantes a possibilidade de se acolher uma tradição, em vistas do seu reposicionamento no presente. Para Bolz, "o passado [deve ser visto] como algo inacabado, algo que não está fechado ${ }^{107 ”}$. Assim, o olhar histórico é sempre um olhar prospectivo, com vistas ao aberto ou inacabado que pode vir a se realizar no presente. Passado que pode voltar sob a forma do sonho e da imagem onírica que, como aquela capaz de fortalecer o sentido de uma ideia, é uma imagem dialética. Se a perspectiva é a do sonho, este momento de confluência (limiar) entre a razão e o mundo onírico é o despertar. Numa das citações das Passagens, Benjamin diz: "Enquanto Aragon persiste no domínio do sonho, deve ser encontrada

\footnotetext{
105 BENJAMIN, Walter. Ibidem. p. 136.

${ }^{106}$ HORKHEIMER, Max. Sobre a metafísica do tempo de Bergson. Trad. Maurício G. Chiarello. São Paulo: Revista USP, no 6, 2000. p. 80.

107 BOLZ, Nobert. "É preciso teologia para pensar o fim da história?” In Revista USP, no15, Dossiê Walter Benjamin. São Paulo. 1992. p. 28.
} 
aqui a constelação do despertar ${ }^{108 "}$. Deve-se, pois, investigar pela razão crítica o potencial dialético que estas imagens suscitam. Porém, como podemos reconhecer estas imagens?

Para explicar a característica destas imagens, Walter Benjamin recorrerá à noção leibniziana de mônada. A mônada, para Leibniz, era a expressão particular do todo universal. Dois princípios de sua filosofia coincidem para a compreensão de seu conceito: o princípio da harmonia preestabelecida e a afirmação de que este mundo, designado por Deus, só poderia ser o "melhor dos mundos possíveis". A mônada, enquanto elemento particular do todo, seria capaz de expressar a totalidade universal de uma forma harmônica. Para Aléxia Bretas, quando Benjamin se vale deste conceito, ele pretende se opor a Descartes e à ideia de dominação através da consciência e da subjetividade, uma vez que confere à objetividade do mundo exterior um valor de expressão que transcende nosso controle, afinal, não estamos no comando absoluto do surgimento das imagens, nós apenas decidimos como podemos nos relacionar com elas depois de despertos: se pelo crivo crítico ou não. Bretas ainda afirma que

\footnotetext{
“Benjamin busca uma reaproximação não-intencional dos objetos, pulverizados em seus minúsculos componentes. [...] Atento aos detalhes, ele celebra a exposição monadológica dos fragmentos $[. . .]^{109 \prime \prime}$.
}

Fragmentos de memória, fragmentos entrecortados de sonho e fragmentos históricos, tais são as imagens benjaminianas capazes de irrompem no curso linear da história e alterá-la significantemente. Em suma: "descobrir na análise do acontecimento individual o cristal do acontecimento total ${ }^{110 "}$. Este cristal do acontecimento total é o cristal da transparência, onde a história, convulsiva em si mesma, se exige em suas projeções negativas ou positivas. André Breton estabelece uma associação entre a beleza do cristal e a sua ideia, ainda vaga, de beleza em L'amour fou:

\footnotetext{
108 BENJAMIN, Walter. Passagens. Org e trad. Willi Bolle. São Paulo. Imprensa Oficial/ Ed. UFMG. 2009. p. 500.

109 BRETAS, Alexia. A constelação do sonho em Walter Benjamin. São Paulo. Humanitas. 2008. p. 43.

${ }^{110}$ BENJAMIN, Walter. Ibidem. p. 503.
} 


\begin{abstract}
“L'oeuvre d'art, au même titre d'ailleurs que tel fragmente de la vie humaine considerée dans sa signification la plus grave, me paraît dénuée de valeur si elle ne présente pas la dureté, la rigidité, la régularité, le lustre sur toutes ses faces extérieures, intérieures, du cristal. [...] La Maison que j'habite, ma vie, ce que j'écris: je rêve que cela apparaisse de loin comme apparaissent de près ces cubes de sel gemme ${ }^{111 "}$.
\end{abstract}

A imagem da gema ou do cristal possibilita ao fruidor da obra vislumbrar o que se passa no interior e no exterior, simultaneamente. A nosso ver, quando o historiador toma a malha histórica desta forma e, ao justapô-la, permite que fatos novos ressurjam, está compreendendo a imagem da história como o surrealista compreende o cristal. Breton chama esta beleza de convulsiva, pois a convulsão nada mais é do que a externalização do emaranhado de pulsões psicológicas ou neurais que, corriqueiramente, tendem a permanecer veladas, imperceptíveis. A historiografia que joga luz à história como o surrealista joga luz ao cristal é capaz de ver as convulsões internas que passaram desapercebidas anteriormente. Este momento de coincidência, em que exterior e interior se comunicam e os opostos se conectam no interior de uma conjunção, é que, a nosso ver, Octavio Paz chamará de instante, como veremos posteriormente. No mais, ao pensar o cristal do acontecimento como convulsivo, Breton talvez resguarde um dos sentidos do próprio termo 'epilepsia': de origem grega, possui a conotação de um "evento inesperado" ou "surpresa", tal como as convulsões históricas.

Dentre as potencialidades históricas às quais nos referimos, gostaríamos de chamar atenção, sobretudo, para aquela que seria capaz de vir à contramão do progresso e seu ritmo destrutivo. Nas Teses sobre o conceito de história, Benjamin aponta que o tempo sucessivo, linear e teleológico do progresso é um tempo vazio, desbotado e sem sentido:

${ }^{111}$ BRETON, André. L'Amour Fou. Saint-Amand: Éditions Gallimard, 2014. p. 17. 
"a ideia de um progresso do gênero humano na história não se pode separar da ideia de sua progressão ao longo do tempo homogêneo e vazio. A crítica da ideia dessa progressão tem de ser a base crítica da própria ideia de progresso ${ }^{112 "}$.

A aceleração do tempo histórico na modernidade está associada, segundo Agamben, ao processo de transição econômica das manufaturas à industrialização. Ao tempo do relógio, irreversível, assoma-se à necessidade por acumulação de capital, tal como pede a doutrina religiosa do lucro. Em O Capitalismo como religião, Walter Benjamin afirma que

\begin{abstract}
"três traços já podem ser identificados na estrutura religiosa do capitalismo. Em primeiro lugar, o capitalismo é uma religião puramente cultual, talvez até a mais extremada que já existiu. Nele, todas as coisas só adquirem significado na relação imediata com o culto; ele não possui nenhuma dogmática, nenhuma teologia. Sob esse aspecto, o utilitarismo obtém sua coloração religiosa. Ligado a essa concreção do culto está um segundo traço do capitalismo: a duração permanente do culto. O capitalismo é a celebração de um culto sans rêve et sans merci [sem sonho e sem piedade]. Para ele, não existe "dias normais", não há dia que não seja festivo no terrível sentido da ostentação de toda a pompa sacral, do empenho extremo do adorador. Em terceiro lugar, esse culto é culpabilizador. O capitalismo presumivelmente é o primeiro caso de culto não expiatório, mas culpabilizador. Nesse aspecto, tal sistema religioso é decorrente de um movimento monstruoso. Uma monstruosa consciência de culpa que não sabe como expiar lança mão do culto [...]. Faz parte da essência desse movimento religioso que é o capitalismo aguentar até o fim, até a culpabilização final e total de Deus, até que seja alcançado o estado de desespero universal, no qual ainda se deposita alguma esperança. Nisto reside o aspecto historicamente inaudito do capitalismo: a religião não é mais reforma do ser, mas seu esfacelamento. Ela é a expansão do desespero ao estado religioso universal, do qual se esperaria a salvação" ${ }^{113}$.
\end{abstract}

\footnotetext{
112 BENJAMIN, Walter. Sobre o conceito de história In O Anjo da História. Trad. João Barrento. Belo Horizonte, Autêntica Editora. 2013. p. 17.

113 BENJAMIN, Walter. O capitalismo como religião. Trad. Nélio Schneider. São Paulo: Boitempo Editorial. 2012. p. 17.
} 
O universo desencantado da modernidade, reforçado pelo processo de racionalização e desencantamento do mundo, apontado por Max Weber, recebe, então, seu preenchimento de "sentido" pelo universo do trabalho. Contudo, não o trabalho como obra, como realização da potencialidade humana, pessoal, criativo e que estivesse em conjunção como a poíesis, enquanto capacidade de "desvelar o sentido humano" nas coisas, atribuindo-Ihes razão de ser, para além da finalidade prática e das necessidades cotidianas, mas o trabalho como realidade exploratória, alienação e escamoteação do ser humano, convertido em ferramenta, peça, engrenagem.

A ideia de Progresso é inerente ao capitalismo. Não é possível pensá-lo, enquanto regime de acumulação de capital, sem reconhecer que há nele um sentido de marcha rumo ao futuro, arquétipo doador de sentido. Contudo, o progresso também se imiscuiu no interior das utopias críticas do século XIX e XX, como é o caso do socialismo. Para Octavio Paz, é necessário reconhecer que há na ideia socialista um princípio humano que é inadiável e do qual jamais poderíamos abrir mão: o sonho de uma sociedade sem desigualdades em que o homem fosse livre de toda exploração. Entretanto, o marxismo, ainda que se embebesse do desenrolar dialético da história proposto por Hegel, não foi capaz de superar a visão linear da história. Em Os Filhos do Barro, Octavio Paz reconhece que "para Marx a história não é plural, é una, e se desdobra como a série de proposições de uma demonstração ${ }^{114 "}$. O erro, portanto, está em se pensar a história como um produto de uma única racionalidade imanente, quando os processos descontínuos e adversos apontam o contrário. O socialismo marxista deposita seu sentido no futuro, mas a esperança utópica que ele reservaria às benesses tão sonhadas pela vanguarda revolucionária, apesar de ter possibilitado novas experiências de configuração socioeconômica que ainda podem ser discutidas, assim como trágicas formas inovadoras de dominação pelo trabalho - como os gulags -, acabaram por desmaterializar e desterritorializar o presente como o local por excelência de nossas experiências de vida. Diante disso, não há outra solução, para Octavio Paz, senão a de

\footnotetext{
${ }^{114}$ PAZ, Octavio. Os Filhos do Barro. Trad. Ari Roitman e Paulina Wacht. São Paulo: Cosac Naify, 2013. p.
} 156 
"renunciarmos à concepção da história como um processo linear progressivo dotado de racionalidade imanente, como previa a visão científica do socialismo. Não é fácil aceitar, porque renunciar a essa crença também implica o fim de nossas pretensões quanto à direção do futuro ${ }^{115 "}$.

O que sobraria, pois, da pretensão humana de uma sociedade sem classes, sem desigualdade e sem exploração do "homem sobre o homem"? Paz pode ser bastante crítico no que toca à sua visão do socialismo real, mas considera que

"no entanto, não se trata de renunciar ao socialismo como livre escolha ética e
política, mas à ideia de socialismo como um produto necessário do processo
histórico. A crítica das aberrações políticas e morais dos "socialismos"
contemporâneos deve começar pela crítica de nossas aberrações
intelectuais"116".

A visão da história, portanto, como unilateral processo com sentido uno e imanente deve ceder lugar a outra concepção, que considere em seu interior a possibilidade de se abarcar múltiplas narrativas, múltiplos sentidos, sobretudo, como sugere Benjamin, narrativas que possibilitem "escovar a história a contrapelo". Trata-se, portanto, de uma visão "plural", ou seja: "história da prodigiosa diversidade de sociedades e civilizações que os homens criaram. Nosso futuro, nossa ideia de futuro, bambeia e balança: a pluralidade de passados torna plausível a pluralidade de futuros ${ }^{117 "}$.

O olhar historiográfico que pretende ver na história os pontos de inflexão em que o sentido contínuo das dominações e explorações cede à liberdade deve estar atento, portanto, às rupturas e breves momentos de descontinuidade que a Fortuna possibilitou ao acaso. Para Michael Lowy,

\footnotetext{
115 Ibidem.

116 Ibidem.

117 Ibidem.
} 


\begin{abstract}
"não há [...] progresso "automático" ou "contínuo"; a única continuidade é a da dominação e o automatismo da história simplesmente reproduz esta ("a regra"). Os únicos momentos de liberdade são interrupções, descontinuidades, quando os oprimidos se sublevam e tentam se emancipar ${ }^{118 " .}$.
\end{abstract}

Podemos pensar que estes momentos de interrupção na história são possíveis graças a uma maior liberdade na capacidade humana de rememorar. Quando a memória não é necessariamente ativa, mas disposta a vasculhar o terreno do presente, em busca dos estímulos que provoquem o despertar das figuras adormecidas, tal qual nos mostra Proust, a sociedade torna-se consciente dos processos nos quais está inserida. Mas, para que isso seja possível, é necessário a presença de uma "outra voz", uma voz que possibilite os diversos regimes de discurso, sobretudo os que estão apagados pelo desenrolar da vida cotidiana, obter o seu espaço.

Na obra de Octavio Paz, assim como na obra de Walter Benjamin, temos um pensamento que leva "o particular ao extremo", ou seja, que visa a dar voz aos fatos negligenciados, pensando-os como paradigmas. A obra de Paz, em geral, é uma realização de espírito crítico que possibilita a percepção destes acontecimentos, ao eleger suas figuras-chave de pensamento, bem como seus objetos poéticos, dando luz e lucidez a formas e experiências que se contrapõem à massificação da sensibilidade pelo poder quase onipresente da técnica. Antes de apontarmos estas obras, gostaríamos apenas de justificar porque essa aproximação entre Octavio Paz e Walter Benjamin é apropriada. Por que mobilizar o pensamento de Benjamin para explicitar a concepção de tempo em Paz? Ora, para Georg Otte, tanto o alemão como o mexicano tiveram de lidar com correntes de pensamento hegemônicas, às quais ambos reagiram: trata-se, sobretudo, do embate à esquerda stalinista que, a despeito de suas posições, não teve o diálogo negado por ambos. Enquanto Benjamin procurou no interior do barroco alemão e nas passagens, bulevares, corredores parisienses as imagens que reservavam conteúdos autônomos em relação à visão corrente da história, $\mathrm{Paz}$, em $O$

\footnotetext{
118 LOWY, Michael. Walter Benjamin: aviso de incêndio: uma leitura das teses "Sobre o conceito de história". Trad. Wanda Nogueira Caldeira Brandt. São Paulo. Boitempo. 2005. p. 117.
} 
Labirinto da Solidão, encarou a figura do imigrante mexicano nos Estados Unidos, o pachuco, como a exceção por natureza de uma espécie de sujeito que é reativo às regras e à normatividade imposta por ambas as culturas. Esta procura pelo excepcional e pelo fragmentário, que conserva outra forma de vivência política, artística e social, é a marca de uma preocupação com a liberdade numa época em que a tirania do Estado, bem como a ferocidade dos mercados, limitava as potencialidades de desenvolvimento dos seres humanos, impedindo seu desenvolvimento individual, bem como incapacitando a possibilidade de uma fraternidade entre sujeitos em ambientes plurais. Não que a coletividade pudesse guardar a autenticidade, de forma exclusiva, mas a abertura do indivíduo à comunidade permite um deslocamento de si mesmo e um contato com o outro que, para Paz, nos constitui como seres humanos. Sobre este ponto de vista, o crítico Otte é bastante pontual:

\footnotetext{
"quando Paz fala, ainda, da "autenticidade popular", ele até se aproxima um pouco do chavão populista segundo o qual o "povo" seria o guardião da autenticidade, ao passo que os poderosos, por estarem no poder, seriam fatalmente corrompidos e alienados por ele. Por outro lado, Paz não tem a pretensão de fornecer uma definição desse ser, mas apenas o usa como categoria negativa que desmente imposições inadequadas ${ }^{119 \prime \prime}$.
}

Já vimos, anteriormente, que o fato de Paz fazer uso das imagens no interior de seu pensamento faz com que, muitas vezes, a dialética não seja a ferramenta crítica mais adequada, apesar de fazer uso dela ${ }^{120}$. Existe, no entanto, um conceito que, no interior do pensamento benjaminiano, possibilita que todas imagens ou conceito negativos, quando alocados num pensamento que visa a superar a teleologia progressiva, tornemse positivos. A apocatástase é um conceito de matriz teológica que parte de uma interpretação na qual, durante o juízo final, todas as almas, mesmo as mais pecadoras e vulgares para os ditames da moral divina, seriam salvas num ato de misericórdia eterna. Nesta salvação universal, todas as almas, inclusive a de Lúcifer, anjo caído, seriam

119 OTTE, George. Algumas afinidades entre Octavio Paz e Walter Benjamin In MACIEL, Maria Esther (Org.) A palavra inquieta: homenagem a Octavio Paz. Belo Horizonte: Autêntica, 1999. p. 198.

${ }^{120}$ Como quando pensa a "Dialética da Solidão" em sua obra O Labirinto da Solidão. 
levadas de novo à presença de Deus. Em suma, trata-se da positivação de todos os fatos e eventos negativados ao longo da história, retirando dela qualquer matriz ontológico ou essencial.

Ora, uma vez que a história não é essencialista, podemos afirmar que nela vigora o acidente. Para Paz,

\footnotetext{
“o signo não-corpo sempre foi repressivo e tem ameaçado o homem com o fogo eterno, o círculo das transmigrações e outras penas terríveis. Agora nos promete a extinção total e acidental, sem distinção entre justos e pecadores. [...] A catástrofe se torna banal ou irrisória porque o Acidente, no final das contas, não passa de um acidente ${ }^{121 "}$.
}

O instante da catástrofe, a iminência da barbárie, o mesmo movimento que faz o anjo da história benjaminiano voltar os olhos para trás é o que, na visão de Paz, possuiria o valor da banalidade. Ao contrário da apocatástase em que todas as almas seriam salvas, Paz aponta que o desenvolvimento técnico nos mostrou que a razão ocidental - em seu desvario - foi capaz de criar a possibilidade de eliminar a todos, por intermédio daquilo que nublou, dentre uma série de fatores e fatos, nossa perspectiva de futuro: a bomba atômica e o iminente cataclisma climático.

Porém, quanto à apocatástase, nas Passagens, Benjamin fará um "uso metódico ${ }^{122 "}$ deste conceito, para pensar os fatos históricos em sua concepção materialista e dialética da história:

\footnotetext{
“Toda negação, por sua vez, tem o seu valor apenas como pano de fundo para os contornos do vivo, do positivo. Por isso, é de importância decisiva aplicar novamente uma divisão a esta parte negativa, inicialmente excluída, de modo que a mudança de ângulo de visão (mas não de critérios!) faça surgir
}

121 PAZ, Octavio. Conjunções e Disjunções. Trad. Lúcia Teixeira Wisnik. São Paulo: Perspectiva, 1979. p. 109.

122 Para usar uma expressão de Nobert Bolz, em que afirma que "Este não é um conceito dogmático, mas metódico, porque se refere a uma técnica de processamento de material, a saber, a técnica que opera com contrastes dialéticos" (BOLZ, Nobert. Ibidem. p. 26). 
novamente, nela também, um elemento positivo e diferente daquele anteriormente especificado. E assim por diante ad infinitum, até que todo o passado seja recolhido no presente em uma apocatástase histórica ${ }^{123 " .}$

A nosso ver, esta postura possibilita que o passado, em sua multiplicidade, se presentifique da mesma forma: plural, possível, provável e inteligível tanto em seu exterior (à medida em que se conecta a uma história que pode ser lida de forma universal) quanto em seu interior (enquanto resguarda as suas singularidades), monadologicamente. A hipótese de "salvação" (ou resgate) de todos os fatos torna possível uma visão da história capaz de realizar no acontecimento presente o desen rolar narrativo de qualquer brecha aberta, a partir de qualquer origem delimitada. Desta forma, pode-se afirmar que "não existe nada de negativo per se $e^{124 "}$. Apostar na ideia de um passado plural é apostar na ideia de uma pluralidade de ritmos de temporais. Ora, se tomamos o tempo através do escopo variável de nossa sensibilidade, temos de dizer que os dados imediatos que dela apreendemos são, antes de tudo, "emoções", "são o efeito que o escoamento do tempo produz sobre a sensibilidade ${ }^{125 "}$. Mas, para além disso, a própria experiência do tempo é, ela também, "emoção". Segundo David Lapoujade, é necessário pensar que

\footnotetext{
“estabelecer uma relação com o passado é estabelecer um vínculo com uma sequência, uma série, de vibrações subjetivas que, por sua vez, estiveram presentes no "ser" da história, uma vez que esta é construída pelo mais variado prisma de emoções e afetos. Devemos reconhecer que as temporalidades que engendram 0 presente não chegam a nós de forma abstrata, mas sensivelmente. "Na profundidade, não somos mais "seres", mas sim vibrações, efeitos de ressonância, "tonalidades" de diferentes frequências. E o próprio universo acaba se desmaterializando para se tornar duração, uma pluralidade
}

${ }^{123}$ BENJAMIN, Walter. Passagens. Org e trad. Willi Bolle. São Paulo. Imprensa Oficial/ Ed. UFMG. 2009. p. 501.

124 Ibidem.

125 LAPOUJADE, David. Potências do Tempo. Trad. Hortencia Santos Lencastre. São Paulo. N-1. edições. 2013. p. 11. 
de ritmos de duração que também se superpõem em profundidade, de acordo com níveis de tensão distintos ${ }^{126 \prime \prime}$.

Ou seja, o sentido destas durações, imagem temporal que Lapoujade extrai de Bergson, é um sentido que deve admitir a pluralidade e, por consequência, as rupturas que movimentam o seu interior de forma tensionada. Assoma-se a isto o argumento de que o que retorna do passado não são os fatos enquanto conceitos, mas sim enquanto imagens. Convém dizer que, ao possibilitar que todo negativo positive-se em sua concepção de história, Benjamin não está com isso adotando uma posição que privilegia apenas o fato bruto - positivo - propriamente dito. Interpretar desta forma seria lhe atribuir uma coloração positivista que o autor não possui. Para George Otte,

\footnotetext{
"um dos alvos da crítica benjaminiana é a visão linear da história, segundo a qual a história nada mais seria do que a sequência de fatos, segundo a qual cada fato novo extinguiria o anterior. Benjamin opõe a esta perspectiva historicista (que, aliás, pode ser chamada de positivista, pois só procura ver o fato puro, positivo), que limita a história a um processo de sucessão e de substituição, a ideia da "presença do passado no presente ${ }^{127 " .}$
}

Qualitativos, os instantes que interrompem o contínuo da história, permitem o contínuo do tempo reprimido vir à tona. Por isso, acrescentamos com Horkheimer que não é abstraindo-se da história, mas sim "tomando consciência de sua correlação com ela que todas as faculdades espirituais organizadas em pensamento podem conseguir que 'la connaissance s'installe dans le mouvant et adopte la vie même des choses ${ }^{128 \prime \prime \prime}$. O pensamento, quer seja metafísico, quer seja poético, não pode se furtar a ignorar a história, mesmo que decida transmuta-la, transfigurá-la ou transcende-la.

\footnotetext{
${ }^{126}$ Ibidem.

${ }_{127}$ OTTE, George. Algumas afinidades entre Octavio Paz e Walter Benjamin In MACIEL, Maria Esther (Org.) A palavra inquieta: homenagem a Octavio Paz. Belo Horizonte: Autêntica, 1999. p. 200.

128 HORKHEIMER, Max. Sobre a metafísica do tempo de Bergson. Trad. Maurício G. Chiarello. São Paulo: Revista USP, no 6, 2000. p. 81.
} 
Tanto Octavio Paz quanto Walter Benjamin pensam o ser humano não apenas como o sujeito conhecedor distanciado da história, mas como um ser a ela integrado, na tessitura do tempo. A experiência histórica concreta, para ambos os autores, é uma experiência que leva em conta o peso de um passado que deve ser lido sob as chaves de uma teoria, em seu sentido mais específico, enquanto perspectiva e capacidade de desvelar, sob um olhar crítico, os fatos transcorridos no tempo, mas que evita a projeção teórica deste mesmo futuro, em vista de uma precisão diagnóstica do presente e da possibilidade de alterá-lo na palavra do dia. Para Georg Otte, trata-se do "cansaço das utopias", um sentimento de enfado diante da tentativa de inserir o presente na via de um futuro como promessa, mas cujo sacrifício é sempre prometeico, isto é, cíclico, pois nunca realizável de todo. Para o crítico,

\footnotetext{
“tanto Paz quanto Benjamin rejeitam essa 'fuga para frente' e querem "redimir" - ambos fazem uso desse termo teológico - o presente, fazendo "explodir o continuum". O ato libertador do presente acontece no presente, e não é protelado para um futuro que, cada vez que não cumpre suas promessas, precisa ser adiado. A "redenção" do presente não significa apenas libertá-lo do peso do passado, mas também de sua subordinação a um 'futuro melhor'. O presente deixa de ser apenas um ponto intermediário e fugaz entre o não-mais e o ainda-não, passando a representar, para Benjamin, uma chance única de reencontrar um passado tido como perdido ${ }^{129 " .}$
}

Octavio Paz, nesta temática, defende que uma perspectiva crítica em relação ao passado pode ser a volta a uma idade de ouro enquanto memória, termo que utiliza em Os Filhos do Barro, onde este passado imemorial significa:

\footnotetext{
"idade bem-aventurada [que] é um tempo de acordo, uma conjunção dos tempos, que só dura um momento. É um verdadeiro acorde: a prodigiosa condensação do tempo numa gota de jade ou numa agulha de ouro é sucedida pela dispersão e pela corrupção. A recorrência nos preserva das mudanças da
}

${ }^{129}$ OTTE, George. Ibidem. p. 199. 
história para submeter-nos mais duramente a elas: deixam de ser um acidente, uma queda ou uma falta para se transformar em momentos sucessivos de um processo inexorável ${ }^{130 \prime \prime}$

A idade bem-aventurada ou idade de ouro é um instante originário, é o cristal monadológico de um momento presente, repleto de sentido, onde toda uma cronologia histórica desemboca no agora: a experiência constituinte de nosso ser, passível de ser vivida, para Paz, na poesia, no amor, na festa e na revolta. A idade de ouro possui sentido em si mesma, pois representa a totalidade para um ser marcado pela cisão e pela mácula - sua finitude, que é marca e condição original de todo ser humano.

Neste sentido, o que poderia oferecer essa visão em conjunto da tríade temporal num único instante? Qual tipo de sensibilidade abriria as portas da percepção para uma situação em que o contínuo passado explodisse e possibilitasse o perfilamento de nossas séries e narrativas no presente? Qual tipo de experiência pode nos colocar fora deste tempo da indústria, deste tempo colonizado e inautêntico, se comparado aos nossos desejos e anseios mais profundos de ser? Em suma, qual espécie de pensamento que, valendo das imagens, tal como fazem Octavio Paz e Walter Benjamin, pode nos oferecer um desvelamento da realidade, que nos coloque para além da capacidade limitada da razão e dos seus mecanismos de redução epistemológica, sem, no entanto, abrir mão da capacidade crítica?

Em O Labirinto da Solidão, Octavio Paz, além dos mais variados temas da cultura mexicana, situa a Filosofia em seu pensamento. Reconhecendo-a como tarefa "urgente e salvadora", o autor a coloca como a empreitada que deve trazer a produção de sentido para os problemas universais que se lançam no mundo contemporâneo, pois, uma vez que nos encontramos num mundo cada vez mais interligado e interdependente, devemos pensar "nos problemas que já não são exclusivamente nossos, e sim de todos os homens ${ }^{131 "}$. Esta possibilidade se torna realizável, pois existem razões que garantem a pré-condição do florescimento de um novo pensamento no mundo, com a descentralização de alguns dos polos mundiais de produção cultural e intelectual, além

\footnotetext{
130 PAZ, Octavio. Ibidem. p. 24.

${ }^{131}$ Id. O Labirinto da Solidão. Trad. Ari Roitman e Paulina Wacht. São Paulo: Cosac Naify, 2014. p. 162.
} 
do desterramento da zona imaginária do futuro utópico imposto pela cultura europeia. O poeta mexicano diz: "Todos estamos à margem, porque já não há mais centro ${ }^{132 " . ~ I s t o ~}$ é, ainda que tenhamos vetores e polos culturais evidentes (como os Estados Unidos, por exemplo), de maior influência econômica e poder de difusão ideológica, Paz considera que o mundo passou por um processo de periferização no âmbito da produção de ideias bem como em seu próprio âmbito estrutural e epistemológico. No mais, como afirma Maria Esther Maciel, este posicionamento crítico corresponde a um "movimento rumo a uma identidade cada vez mais repleta de singularidades dissonantes ${ }^{133 \prime}$. Ou seja, ao desalojar o centro e aloca-lo nas diversas periferias do globo, não apenas Octavio Paz, mas uma série de atores latino-americanos como Borges, Cortazar, Carpentier, etc. produziram uma

\footnotetext{
“literatura que, embora pertencente a um continente de precária modernização econômica, vem, por um processo contínuo de transculturação, alterando sensivelmente não só os rumos da literatura e do pensamento europeus, quanto do próprio conceito de "universalidade", tradicionalmente circunscrito à produção literária dos grandes centros culturais do ocidente ${ }^{134 \prime}$.
}

Ao forçar esta dialética entre particular e universal, Paz reconstrói a história através de seus recortes singulares no tempo e a elevação dos seus conteúdos subterrâneos, recriando estes mesmos espaços. E por que o faz? Ora, Octavio Paz concorda com a máxima de Ortega y Gasset, para quem "a perda da imagem do futuro [...] implica numa mutilação do passado ${ }^{135 " . ~ P o r t a n t o, ~ " e ́ ~ n a ~ m e d i d a ~ d e s s a ~ m o b i l i d a d e ~ t e m p o r a l ~ e ~ e s p a c i a l ~}$ que Paz vai também recriar, a partir da estética barroca de Sor Juana, a obra de Mallarmé e, por extensão, a sua própria ${ }^{136 "}$.

\footnotetext{
132 Ibidem. p. 163.

133 MACIEL, Maria Esther. Voo transverso: Poesia, Modernidade e Fim do Século XX. Rio de Janeiro: Sete Letras, 1999. p. 128.

134 Ibidem.

135 Id. Signos em Rotação. Trad. Sebastião Uchoa Leite. São Paulo: Perspectiva, 2009. p. 105.

${ }^{136}$ MACIEL, Maria Esther. Ibidem. p. 135.
} 
Com isto, queremos dizer que pensar a experiência histórica como justaposição é possível, para Paz, pois a sua própria formação de ideias atende a um descentramento. Paz veicula imagens e, ao fazer análise teórica, poetiza; assim como, ao fazer poesia, está plenamente consciente das aporias conceituais a que força à linguagem ou que, simplesmente, possibilita que aflorem através do movimento rítmico das imagens. Trata-se de um "método", por assim dizer, um modus operandi imagético-conceitual ou, se formos denominar em apenas um termo o pensamento constelacional e poético do autor: analógico ${ }^{137}$. A todo o momento, o autor esteve preocupado com a questão das imagens de tempo que orientam nosso mundo, desde a sua análise das temporalidades cíclicas da Antiguidade, das comunidades pré-colombianas e indianas, das religiões budista, cristã e hindu, até a análise da aceleração do tempo histórico da modernidade industrial. Por isso, faz-se necessário compreender como se dá a inserção do autor naquilo que escreve: como o poeta vivencia, seja na criação poética, seja na postura crítica, o tempo refeito da sensibilidade do "agora". Ou seja, trata-se de pensar como o "agora", enquanto miríade de possibilidades, este talvez presente em Sor Juana e Mallarmé, pode abarcar a pluralidade de tempos do mundo e, ademais, como o ensaio, a poesia e a crítica de Octavio Paz possibilitam a sua compreensão. Não apenas no que toca ao objeto de suas reflexões, é possível também vislumbrar uma experiência desta temporalidade poética na própria escritura do autor, inclusive em suas entrelinhas. Em outras palavras, sobre os ensaios de Paz, em geral, escritos em prosa argumentativa e poética, é possível aferir que

\footnotetext{
"a escrita controla mais a lógica da argumentação avançada pelo intérprete do que faz crer a simples leitura das ideias desenvolvidas pelo discurso hermenêutico. [...]. Ao se ausentar da sua linguagem no momento em que a consigna por escrito na folha de papel, ao abandonar a palavra viva, falada, ao leitor, o escritor perde totalmente o controle semântico do ensaio. Ele deixa irromper na área de circulação das ideias a garantia definitiva de vida da palavra morta, e abre a possibilidade para outras e sucessivas gerações de narrativas pessoais e possivelmente originais, como esta ${ }^{138 " .}$
}

\footnotetext{
${ }^{137}$ Cf. MACIEL, Maria Esther. As Vertigens da Lucidez. São Paulo: Experimento, 1995. p. 25.

${ }^{138}$ SANTIAGO, Silviano. As Raízes e o Labirinto da América Latina. Rio de Janeiro: Rocco, 2006. p. 98.
} 
No jogo linguístico de ausência e presença do autor em seu texto, Paz nos permite vislumbrar uma experiência da temporalidade no interior de um discurso coerente em seus ensaios e na própria estrutura de seus poemas, a experiência da justaposição.

Ao contrário de pensarmos que uma postura a contrapelo do tempo histórico, uma postura onde "escrever não teria outra serventia senão a de evidenciar a coerência de tantos acontecimentos habitualmente negligenciados por terem sido considerados negligenciáveis ${ }^{139 "}$, como se propõe o surrealismo, seja uma defesa da mera restauração nostálgica do passado no presente - o que é extremamente problemático num contexto como o da América Latina, onde as explorações e opressões são históricas -, devemos compreender o resgate de tais 'fatos negligenciados' como, "igualmente, de maneira inseparável, [uma] emergência do diferente ${ }^{140 ”}$. Mais do que a emergência da diferença, para concordar com Nietzsche em Humano, demasiado humano, devemos ter que

\footnotetext{
“a observação imediata de si está longe de ser suficiente para aprender a se conhecer: precisamos de história, pois o passado continua a correr em nós em cem ondas; nós próprios nada somos senão aquilo que sentimos dessa correnteza a cada instante. Até mesmo aqui, se quisermos entrar no rio de nosso ser aparentemente mais próprio e mais pessoal, vale a proposição de

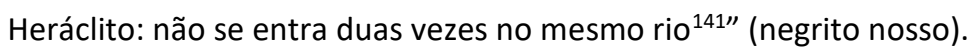

Portanto, existe uma dimensão na poesia e no pensamento poético de Paz capaz de fazer falar os mortos, ou seja, capaz de compreender o tempo como transfigurador da história, num processo em que a poesia desempenha um papel fundamental, enquanto fundadora de imagens de tempo.

A escrita de Paz é marcada por uma significativa quantidade de metáforas e paradoxos, idas e vindas, de modo que o escritor, muitas vezes, consegue extrair das

\footnotetext{
139 LE BRUN, Annie. História de um desastre in BRETON, A. Nadja. São Paulo. Cosac Naify. 2007. p. 151.

${ }^{140}$ GAGNEBIN, Jean Marie. História e Narração em Walter Benjamin. São Paulo: Perspectiva, 2007. p. 18. ${ }^{141}$ NIETZSCHE, Friedrich. Humano, demasiado humano IN Obras incompletas. Col. Os Pensadores. Trad. Rubens Rodrigues Torres Filho. São Paulo. Abril Cultural. 1983. p. 138.
} 
contradições em que se enreda um sentido que não é, por vezes, preciso, mas que é sempre aberto e coerente. Se verificamos no autor a disposição a tornar o tempo o centro de suas reflexões, por outro lado, reconhecemos que Paz estabelece uma maneira distinta de nos apresentar uma reflexão que seja dotada de "centro". Podemos afirmar que, ao jogar com diferentes sentidos para o tempo (Paz o considera plural e isso legitima este jogo linguístico), o autor estabelece uma afirmação da diferença. Por isso, ao incorporar a temporalidade na estrutura de sua escrita poética, Paz age de maneira similar à forma que Lévi-Strauss tratou do mito bororo em Le Cru et le cuit, pois o discurso obedece uma orientação mitopoética, já que "deve ter a forma daquilo de que fala [...] para apreender a forma e o movimento do mito [e] evitar a violência que consistiria em centrar uma linguagem descritiva de uma estrutura acêntrica ${ }^{142 " . ~ N a ̃ o ~ q u e ~}$ a poesia mimetize a imagem de tempo. Ao assumir a forma daquilo de que fala, neste caso, ao assumir a imagem do tempo, a poesia o transfigura. Adorno, em O Ensaio como forma, ao comentar a citação de Nietzsche que replicamos acima, afirma:

\footnotetext{
"supondo que digamos sim a um único instante, com isso estamos dizendo sim não só a nós mesmos, mas a toda existência. Pois não há nada apenas para si, nem em nós e nem nas coisas: e se apenas por uma única vez nossa alma tiver vibrado e ressoado de felicidade, como uma corda, então todas as eternidades foram necessárias para suscitar esse evento - e nesse único instante de nosso 'sim' toda eternidade terá sido aprovada, redimida, justificada e afirmada ${ }^{143 "}$.
}

Este instante em que nossa existência se justifica é o mesmo em que a mirada de Juana Inés se lança ao cosmo e que Mallarmé lança os seus dados. A coincidência, o encontro e a objetividade do acaso, no momento em que Paz se encontra nestes autores e autoras que compõe seu repertório e sua constelação de pensamento pode, também, ser compreendida como um momento pertencente ao instante maravilhoso, no caso, da aventura que não é apenas poética, mas intelectual.

\footnotetext{
142 DERRIDA, J. A escritura e a diferença. Trad. Maria Beatriz Marques Nizza da Silva, Pedro Leite Lopes e Pérola de Carvalho. São Paulo: Perspectiva. 2011. p. 418.

${ }^{143}$ ADORNO, Thedor. O ensaio como forma. Trad. Jorge de Almeida. In Notas de literatura I. São Paulo: Ed. 34. 2012, p. 45.
} 
Podemos, por isso, dizer que Octavio Paz assume uma ausência de centralidade em suas análises, ao reconhecer uma pluralidade de temporalidades em conjunto com abordagens teóricas variadas no interior dos objetos investigados. A partir daí, Paz deriva a peculiaridade de sua escrita ensaística, que se dá sob a forma da prosa-poética, cotejada pela sistematicidade lógico-argumentativa, para que não se perca o teor poético nem a coerência discursiva do olhar analítico que o autor emprega. Trata-se da conceituação-imagética. A verdade é que o centro do objeto investigado deve ser a imagem de tempo que ainda não conseguimos vislumbrar e que o autor crê ser a do "agora", uma vez que entre aquilo que se produz no campo da cultura é diretamente correlato à experiência temporal que possuímos de nosso presente. Por isso, Octavio Paz afirma em Signos em Rotação:

\footnotetext{
"esse além está aqui, sempre aqui e neste momento. A verdadeira vida não se opõe nem à vida cotidiana nem à heroica; é a percepção do relampejar da outridade em qualquer dos nossos atos, sem excluir os mais mesquinhos. [...] A outridade é antes de mais nada a percepção de que somos outros sem deixar de ser o que somos e que, sem deixar de estar onde estamos, nosso verdadeiro ser está em outra parte. Em outra parte, quero dizer: aqui, agora, enquanto faço isto ou aquilo. E também: estou só e estou contigo em um não sei onde que é sempre aquii"144".
}

A experiência da outridade é a experiência humana por excelência, pois orienta significativamente nossas construções culturais, ideológicas, sociais, poéticas e filosóficas. A operacionalidade deste conceito de alteridade em Paz está presente também no primeiro capítulo de $O$ Labirinto da Solidão quando, ao pensar a figura do pachuco, Paz afirma:

\footnotetext{
"pensei então - e continuo pensando - que naqueles homens amanhecia

"outro homem". [...]. Quem já viu a esperança não esquece dela. Procura-a sob todos os céus e entre todos os homens. E sonha que um dia vai encontrá-la de novo, não sabe aonde, talvez entre os seus. Em cada homem lateja a possibilidade de ser, ou, mais exatamente, de tornar a ser, outro homem ${ }^{145 " .}$
}

\footnotetext{
${ }^{144}$ PAZ, Octavio. Signos em Rotação. Trad. Sebatião Uchoa Leite. São Paulo. Perspectiva. 2009. p. 107.

${ }^{145}$ Id. O Labirinto da Solidão. Trad. Eliane Zagury. Rio de Janeiro. Paz e Terra. 2006. p. 29.
} 
Se fossemos falar sobre a ideia de algum centro para Octavio Paz, este diria que o centro é sempre outra coisa ou outro centro: talvez um ideograma móvel ou uma constelação, representantes da pluralidade.

Se, como pensa Derrida, a função do centro no interior de um sistema é organizálo, delimitando seu alcance, relacionando-o a uma origem fixa, então:

\begin{abstract}
"toda a história do conceito de estrutura ${ }^{146}[\ldots]$ tem de ser pensada como uma série de substituições de centro para centro, um encadeamento de determinações do centro. O centro recebe, sucessiva e regularmente, formas ou nomes diferentes. A história da metafísica, como a história do Ocidente, seria a história dessas metáforas e dessas metonímias. A sua forma matriarcal seria [...] a determinação do Ser como presença em todos os sentidos desta palavra. Poder-se-ia mostrar que todos os nomes do fundamento, do princípio ou do centro, sempre designaram o invariante de uma presença (eidos, arquê, télos, energeia, ousia [essência, existência, substância, sujeito] aletheia,

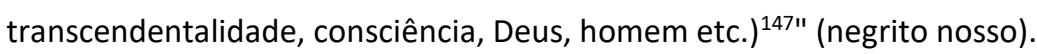

Mesmo os autores (como Nietzsche, Freud e Heidegger) que apontam para certa descentralização em suas filosofias, usufruem do arcabouço teórico legado pela tradição metafísica, ainda presa ao escopo da centralidade. Porém, o pensamento filosófico que esboça uma "saída da filosofia" não requer que se "reduza" o pensamento à conceituação inerente e à centralidade, pois a determinação do Ser como presença, ainda que se valha de conceitos usados (apenas em seu valor metodológico e não em seu valor de verdade) de forma coerente, apesar de gastos pela tradição, podem ser trabalhados sem uma referência supostamente necessária a seus enlaces conteudísticos e ontológicos. Derrida considera que a opção de os inserir, à maneira de Lévi-Strauss, que em suas obras de etnologia os usou como recurso metodológico, nos permite, se

\footnotetext{
${ }^{146}$ Octavio Paz trabalha com a noção de arquétipo (arché) para pensar as imagens de tempo em Os Filhos do Barro e em $O$ Arco e a Lira, sobretudo para se referir às imagens de tempo das culturas antigas e "primitivas"/complexas. Derrida apresenta, segundo a citação apresentada, uma intima relação metafórica entre tais conceitos, pois ambos apontam para uma determinação do Ser enquanto presença. 147 DERRIDA, Jacques. Ibidem. p. 409.
} 
denunciados os seus limites conceituais e linguísticos, a sua ressignificação ou seu consequente abandono em vista de instrumentos renovados que podem vir a surgir, já numa maneira descentralizada de compreensão do mundo.

Porém, quando pensamos o mundo sob a égide da imagem, a presença pode se clarear sem tais custos, isto é, sem tal flexão referencial ao centro discursivo. Quando Paz força as imagens a se justaporem diante de seus contrários ou, quando desenvolve um conceito que, à primeira vista, nos soa como algo completamente contraditório, como a ideia de "tradição da ruptura", devemos levar em conta que o autor está a jogar com um centro lógico que deveria estar pressuposto em sua obra mas que, se buscarmos identifica-lo, este não se encontrará no leque de opções descritas anteriormente por Derrida, pois parece deslocar-se. Nesse tema, tanto na poesia como na reflexão sobre a poesia, Paz se alude ao Ser enquanto presença ${ }^{148}$. Em La otra voz, o poeta diz que "el presente es el fruto en el que la vida y la muerte se funden ${ }^{149 " . ~ D e s s e ~}$ modo, a força com que as contradições e paradoxos se "friccionam", por assim dizer, e geram discursos coerentes nos ensaios de Paz, pode apontar justamente para isso que Derrida indicou como "expressão de um desejo", uma vez que a temática da temporalidade preside a maior parte das reflexões de Octavio Paz. A conjunção mortevida é um retrato do que pode a poesia oferecer, enquanto busca de sentido no agora, desafiando os limites da própria lógica. Paz pensa esta questão numa época espoliada,

\footnotetext{
${ }^{148}$ Como se vê no trecho final do texto de Apresentação do 10 volume das Obras Completas de Octavio Paz, La Casa de la presencia: "Vivimos no el fin de un siglo sino de una era histórica. ¿Comienza otra época o, según há ocurrido más de una vez, la crisis de hoy es el preludio de un renacimiento? ¿Quién lo sabe? Algo, sin embargo, puede decirse: el futuro no existe. Más exactamente: es una invención del presente. La misión de los hombres, a un tiempo condena y salvación, consiste en inventarlo cada día. Algunas generaciones no se atrevieron y repitieron mecánicamente los gestos del pasado, hasta petrificarse; otras, más cercanas, poseídas por los demonios del cambio y el odio a su pasado, convirtieron el futuro en un idolo monstruoso. Sacrificaron al presente por una palabra que hoy se ha disipado. Pero la invención del futuro no implica la destrucción del pasado. Ahora sabemos que nunca muere del todo y que es vengativo: a veces resucita en forma de pasiones espantables y obsesiones inicuas. La poesía es la memoria de los pueblos y una de sus funciones, quizá la primordial, es precisamente la transfiguración del pasado en presencia viva. La poesía exorciza el pasado; aí vuelve habitable al presente. Todos los tiempos, del tiempo mítico largo como un milenio a la centella del instante, tocados por la poesía, se vuelven presente. Lo que pasa en un poema, sea la caída de Troya o el abrazo precario de los amantes, está pasando siempre. El presente de la poesía es una transfiguración: el tiempo encarna en una presencia. El poema es la casa de la presencia. Tejido de palabras hechas de aire, el poema es infinitamente frágil y, no obstante, infinitamente resistente. Es un perpetuo desafío a la pesantez de la historia." (PAZ, Octavio. La casa de la presencia in Obras completas. Vol. I. Cuidad de México: Fondo de Cultura Económica, 2003. p.27)

${ }^{149}$ Id. La otra voz. In Ibidem, 2003. p. 516.
} 
em que morrer não parece menos com a assombrosa obrigação de existir e o que o sentido poético pode oferecer é justamente o fato de que

\begin{abstract}
"la poesía ha sido siempre la visión de una presencia en la que se reconcilian las dos mitades de la esfera. Presencia plural: muchas veces, en el curso de la historia, ha cambiado de rosto y de nombre; sin embargo, a través de esos cambios, es una. No se anula en la diversidad de sus apariciones; incluso cuando se identifica con la vacuidad, como ocurre en la tradición budista y en algunos poetas modernos de Occidente, se manifiesta - insigne paradoja - como presencia. No es una idea: es tiempo puro. Tiempo y no medida: este tiempo singular, único y particular que ahora mismo está pasando y que pasa sin cesar desde el principio. La presencia es el ahora encarnado ${ }^{150 "}$ (negrito nosso).
\end{abstract}

O "ahora encarnado", o tempo-do-agora, é o que possibilita que a própria história do México, assim como a tradição poética ocidental, sejam lidas de uma forma não-linear.

Será, portanto, graças a isso que Octavio Paz chegará à seguinte sentença acerca da história mexicana, tema que percorre toda a biografia de Sor Juana:

\footnotetext{
"conclusão: existe continuidade, sim, mas quebrada, interrompida aqui e ali. Mais do que de continuidade, devemos falar de sobreposições. Em vez de conceber a história do México como um processo linear, deveríamos vê-la como uma justaposição de sociedades diferentes ${ }^{151 "}$.
}

Por sua vez, o que é a história do México diante da chamada "história universal"? Assim como a biografia de Sor Juana, bem como toda a bibliografia por ela produzida, trata-se de uma página da dita "história universal". Pensar a história como justaposição implica em supor que, ao vislumbrá-la através de seus traços sincrônicos, estamos a escová-la a contrapelo. Ao conferir sentido a instantes antes negligenciados, Paz está dando outro

\footnotetext{
150 Ibidem.

${ }^{151}$ PAZ, Octavio. Sor Juana Inés de la Cruz ou As armadilhas da fé. Trad. Wladir Dupont. São Paulo: Ubu Editora, 2017. p. 22.
} 
sentido ao que poderia ser encarado como episódico ou fragmentário ${ }^{152}$, simplesmente, mas que, contudo, pode ser compreendido sob a ótica da mônada: o fragmento, a partícula individual, que expressa o todo universal, à maneira da página mallarmaica que expressa o cosmo.

A este respeito, Walter Benjamin afirma na tese XIV em Sobre o conceito de História que: "A história é objeto de uma construção cujo lugar é constituído não por um tempo vazio e homogêneo, mas por um tempo preenchido pelo Agora (Jetztzeit) ${ }^{153 "}$. Agora, "agoridade" (Haroldo de Campos) ou tempo-do-agora (na tradução de JeanneMarie Gagnebin) pode ser compreendido como a possibilidade de o passado, ocultado, tornar-se inteligível no presente, significando-o. Trata-se, portanto, de sua conversão em mônada, cuja definição, deste conceito de extração leibniziana, será exposto por Benjamin da seguinte forma:

\begin{abstract}
“Nessa estrutura, ele reconhece o sinal de uma paragem messiânica do acontecer ou, por outras palavras, o sinal de uma oportunidade revolucionária na luta pelo passado reprimido. E aproveita essa oportunidade para forçar uma determinada época a sair do fluxo homogêneo da história; assim, arranca uma determinada vida à sua época e uma determinada obra ao conjunto de uma oeuvre ${ }^{154 \prime \prime}$.
\end{abstract}

Do que se pode depreender que, ainda que não assumamos a postura do materialista histórico e a do revolucionário (e Paz certamente não o assumiu, pelo menos não integralmente), é necessário reconhecer que a dimensão do evento histórico entrevista pela mônada mostra que, no interior da racionalidade da série histórica que se possibilita diante de nós, a sua eclosão numa constelação - muitas vezes carregada de tensões e atravessada por choques - pode oferecer uma origem que se comensurará no

\footnotetext{
${ }^{152}$ Em verdade, o poeta dirá em O Labirinto da Solidão: "nossa história não passa de um fragmento da história universal. Quero dizer: sempre, exceto no momento da revolução, vivemos nossa história como um episódio da história do mundo. [...] Portanto, a mexicanidade [...] é uma oscilação entre vários projetos universais, sucessivamente transplantados ou impostos e atualmente todos inúteis" (negrito nosso). (PAZ, Octavio. Op. Cit. Trad. Ari Roitman e Paulina Wacht. São Paulo: Cosac Naify, 2014. p. 162)

${ }^{153}$ BENJAMIN, Walter. O Anjo da História. Trad. João Barrento. Belo Horizonte: Autêntica Editora, 2013. p. 18.

154 Ibidem.
} 
presente, fornecendo-Ihe sentido. Será esta constelação, pois, que permitirá o enquadramento dos fluxos transcorrentes da história emergir no "tempo-do-agora", isto é, no momento em que consciência da tradição e da história se torna cognoscível: o ponto de virada da ruptura, o instante. Mesmo Mario Vargas Llosa ${ }^{155}$, em debate com Octavio Paz, reconhece que a Revolução Mexicana, da qual o escritor peruano era crítico, teve como uma de suas virtudes o estabelecimento e a reivindicação de um passado comum.

Para além disso, é necessário dizer que, muitas vezes, o passado retorna sem reivindicação, tal como apregoação da Fortuna. O século XX nos demonstrou isto de diversas formas. À semelhança do mito celta descrito por Proust, as imagens dialéticas podem ser despertadas à medida em que, no nosso sonho cotidiano, avançamos em direção a elas. Porém, nem sempre seu caráter histórico está claro. Walter Benjamin, em um de seus fragmentos dispersos afirma, acerca da cognoscibilidade do instante histórico, que "o conhecimento nesse momento histórico é sempre o conhecimento de um momento. Na medida em que o passado se concentra no instante - na imagem dialética -, ele entra na memória involuntária da humanidade ${ }^{156 ”}$. Em “Poíesis' e política: o modelo intelectual de Octavio Paz, Horácio Costa relata como sinais de vitalidade de antigas potencialidades, que estavam aparentemente mortas ou superadas, podem voltar à tona com vivacidade. Trata-se do exemplo da cidade de Chemnitz, antiga Karl Marx Stadt, do centro industrial da Saxônia, na antiga Alemanha oriental. Submetida à doutrina universalista do marxismo internacionalista, a cidade resguardava antigos traços de imagens arcaicas adormecidas no inconsciente coletivo da cidade, até que o ideário concreto do socialismo alemão ruiu no pós-1989. Nas palavras do autor:

\footnotetext{
"O gesto de chamar Chemnitz de Karl Marx Stadt harmonizava-se com uma visão de mundo, finalista e utópica, que se instaurou na realidade de modo messiânico e se plantou no devir como a realização de uma utopia. No caso da Europa do Leste, o trânsito entre a projetada utopia e a distopia realizada se
}

\footnotetext{
${ }^{155} \mathrm{E}$, neste sentido, curiosamente, faz ressonância à seguinte ideia benjaminiana: "A história tem como tarefa não apenas apropriar-se da tradição dos oprimidos, mas também fundá-la" (BENJAMIN, Walter. $O$ anjo da história. Trad. João Barrento. Belo Horizonte: Autêntica, 2013. p. 192.)

156 Ibidem. p. 179.
} 
deu no curto período de duas ou três gerações. O que, em sua origem ideal, se apresentava como uma alternativa aos modelos civilizatórios até então conhecidos, revelou-se como uma forma, renovada e antiga, de barbárie. [...] $\mathrm{O}$ que pretende a comunidade que volta a chamar sua cidade com o nome ancestral é devolver à circulação social a espessura humana acima referida, a pluralidade de tempos e perfis e traços e vozes, que a nova ordem implantada no pós-guerra, com sua interpretação redutiva da história, tentara banir da vida coletiva ${ }^{157 \prime \prime}$.

Recentemente, a cidade de Chemnitz ${ }^{158}$ enfrenta uma polarização entre forças representativas de antigos impulsos por um lado e o Estado democrático de direito do outro. Refiro-me à escalada de manifestações neonazistas que alertaram algumas autoridades sobre o risco de se atingir um ponto em que não seja possível retroceder. A atualização desta questão apenas serve para explanar que a defesa da pluralidade de vivências e experiências (inclusive de tempo) deve ser constante ${ }^{159}$.

Por outro lado, a particularidade da história mexicana se choca com a sua sequência de rupturas e períodos de convergência com as ideias vindas de fora. Por isso, poder-se-ia questionar: por qual motivo Octavio Paz chega não apenas a sugerir que o México merece um olhar mais acurado e cuidadoso em relação às leituras históricas que fazemos dele, mas, ademais, que merece receber a elaboração de uma Filosofia da História? Como realizar isso se, para o autor, a história mexicana sempre foi um

${ }^{157}$ COSTA, Horácio. "Poíesis" e política: o modelo intelectual de Octavio Paz. Revista USP: São Paulo. 1991. p. 82.

158 DEUTSCHE WELLE. Chemnitz põe a democracia em perigo na Alemanha? Disponível em: https://www.dw.com/pt-002/chemnitz-p\%C3\%B5e-a-democracia-em-perigo-na-alemanha/a-45310676/ [Acesso em 30 de Junho de 2019].

${ }^{159}$ Segundo Franco Berardi, o que explica esse recrudescimento das forças de extrema direita no mundo globalizado é seu mergulho numa espécie de desordem mental, baseada na impotência e no desprezo. Para o italiano, este fenômeno, ainda que faça menção ao fascismo, não deve ser interpretado como uma nova aparição deste, uma vez que, neste, a agressividade política e a potência sexual estavam interligadas. Para ele, "hoje, pessoas brancas votam em partidos nacionalistas não porque acreditam pertencer a uma comunidade, mas porque gostariam de resgatar esse sentimento do passado. Elas cresceram na era do individualismo desenfreado, confiaram nas promessas do egoísmo neoliberal e se descobriram perdedoras. [...] Agora é tarde demais para abraçar uma nova esperança, uma nova imaginação: a única coisa que conseguem é fazer compartilhar seu ódio e seu desejo de vingança" (BERARDI, Franco. Depois do futuro. Trad. Regina Silva. São Paulo: Ubu Editora, 2019. p. 9) 
fragmento da história universal (ou da que se pretende universal)? Ao que Octavio Paz nos responde:

\footnotetext{
"uma filosofia da história do México seria, pois, apenas uma reflexão sobre as atitudes que assumimos diante dos temas que a história universal nos propôs: contrarreforma, racionalismo, positivismo, socialismo. Em suma, a meditação histórica nos levaria a responder esta pergunta: como os mexicanos viveram as ideias universais? [...] Uma filosofia mexicana terá de enfrentar a ambiguidade de nossa tradição e da nossa própria vontade de ser, que, se exige plena originalidade nacional, não se satisfaz com alguma coisa que não implique numa solução universal| ${ }^{160 "}$.
}

No sistema leibniziano, a mônada não possuiria razão de ser (e no sistema metafísico de Leibniz, o princípio da harmonia preestabelecida prevê que todas substâncias possuem) caso não expressasse, no interior de sua particularidade, o universal. Compreender a história como justaposição é sugerir que, no mínimo, cada partícula se conecta às demais, de forma a construir um todo inteligível que possibilite uma leitura (material e metodológica) que ofereça uma narrativa alheia à dominante.

Por conta disto, longe de pensar uma filosofia "nacional", o poeta parte da perspectiva de que, na construção de um pensamento local que dialoga com as tendências mundiais e as correntes de ideias universais, há a possibilidade de realização de uma filosofia cosmopolita. A nosso ver, a base do pensamento histórico de Paz é a solidão, experiência que relata, profundamente, em seu livro $O$ Labirinto da Solidão. A condição de se filosofar no mundo contemporâneo é saber-se só, é saber-se em busca do outro, e esta procura, pois, é uma condição que é acentuada para o latino-americano. Por isso, convém comparar duas citações que versam sobre esta condição universal. Em primeiro lugar, o regionalista Gabriel García Márquez diz no pronunciamento A solidão da América Latina, denunciando esta condição que, antes de alargar-se ao mundo contemporâneo, já nos era historicamente imposta:

${ }^{160}$ Ibidem. p. 150. 


\begin{abstract}
"Por que a originalidade que é admitida sem reservas em nossa literatura nos é negada com todo tipo de desconfiança em nossas tentativas tão difíceis de mudança social? Por que pensar que a justiça social que os europeus desenvolvidos tratam de impor em seus países não pode ser também um objetivo latino-americano, com métodos distintos e em condições diferentes? Não: a violência e a dor desmedidas da nossa história são resultados de injustiças seculares e amarguras sem conta, e não uma fabulação urdida a três mil léguas de nossa casa. Mas muitos dirigentes e pensadores europeus acreditam nisso, com o infantilismo dos avós que esqueceram as loucuras frutíferas de sua juventude, como se não fosse possível outro destino além de viver à mercê dos dois grandes donos do mundo. Este é, amigos, o tamanho da nossa solidão ${ }^{161 "}$.
\end{abstract}

\title{
E, em segundo, Paz afirma n'O Labirinto da Solidão que
}

\begin{abstract}
"a existência de um sentimento real ou suposta inferioridade diante do mundo poderia explicar, parcialmente pelo menos, a reserva com que o mexicano se apresenta aos demais e a violência inesperada com que as forças reprimidas quebram essa máscara impassível. Entretanto mais vasta e profunda que o sentimento de inferioridade, jaz a solidão. É impossível identificar ambas as atitudes: sentir-se só não é sentir-se inferior, mas sim diferente. $O$ sentimento de solidão, por outro lado, não é uma ilusão - como às vezes é o de inferioridade -, e sim a expressão de um fato real: somos, na verdade, diferentes. E, na verdade, estamos sós ${ }^{162 " .}$
\end{abstract}

Verificar na solidão o registro da diferença e, ao mesmo tempo, a condição de ser latinoamericano permite vislumbrar a identificação do ponto ou signo, ou melhor, um dos pontos de descentramento que uma filosofia surgida na América Latina deveria levar consigo, além da nossa experiência particular da temporalidade. A solidão, por ser

${ }^{161}$ GARCIA MARQUEZ, Gabriel. Cem anos de Solidão. Trad. Eric Nepomuceno. São Paulo: Record, 2014. p.11.

162 PAZ, Octavio. O Labirinto da Solidão. Trad. Eliane Zagury. Rio de Janeiro: Paz e Terra, 2006. p. 22. 
mácula, procura, busca do outro, funcionaria como um centro móvel, pois nos lançaria em busca do outro como numa convergente busca de sentido.

Portanto, se, por um lado, a história mexicana se coloca como fragmento e fragmentária, é possível falar em múltiplos fragmentos que, por si só, apresentam uma visão de mundo autêntica. A importância da ideia de "fragmento" corresponde à postura do autor em relação à história. Tal como um mosaico, a narrativa da história, muitas vezes, é descontínua, confusa e repleta de rupturas. Diante disto, é necessário obter meios de reconstruí-la, sem lapidar tais fragmentos, conservando-os em sua integridade, como o fazem as alegorias. Por conseguinte, não apenas a história lidará com eles, mas também a poesia:

\footnotetext{
"A poesia não se propõe a consolar o homem da morte, mas fazer com que ele vislumbre que a vida e a morte são inseparáveis: são totalidade. Recuperar a vida concreta significa recuperar a parelha vida-morte, reconquistar um no outro, o tu no eu, e assim descobrir a figura do mundo na dispersão de seus fragmentos $^{163 "}$ (destaque nosso).
}

Figura do mundo ou imagem do mundo que significam, basicamente, imagem de tempo.

Pensar a história do México como a reunião de fragmentos dispersos é também verificar como algumas práticas e instituições arraigadas no contexto social se expressam. Muitas vezes, nestas expressões, reside a marca da temporalidade. Ao pensar o Vice-Reinado da Nova Espanha, Paz dá destaque a certos tipos de experiência que possibilitam a reunião do grupo social por intermédio de um símbolo ou de uma imagem. Trata-se da festa, experiência coletiva que costuma aparecer em vários momentos na bibliografia paziana. Em As Armadilhas da Fé, Paz destaca que as festas também foram importantes na produção poética de Sor Juana, sobretudo se pensarmos nos vilancetes. Ao se referir à prática festiva do Vice-Reinado da Nova Espanha, Octavio Paz assim define:

\footnotetext{
163 PAZ, Octavio. Signos em rotação. Trad. Sebastião Uchoa Leite; Col. Debates, no48; São Paulo;
} Perspectiva; 2009. p. 110. 
"reunião dos elementos que o compõe em um todo que também é único; quero dizer, uma totalidade encarnada numa unidade. Mas também reunião da sociedade com seu passado - seus mortos, heróis, santos, fundadores - e seu futuro: o amanhã histórico e o tempo sem medida do divino ${ }^{164 "}$.

Podemos afirmar que o que garante a unidade é a comunhão da mesma experiência temporal, no caso, este tempo sem medida do divino. Neste sentido, convergem religião, sociedade e política. Condensados na experiência do divino, o Outro é desocultado, o mexicano da Nova Espanha o vive através da participação na coletividade em celebração. Seria supérfluo afirmar que a festa pressupunha a organização burocrática que está presente em toda forma de Estado, pois os próprios "vilancetes eram espetáculos e os espetáculos [...] requerem diretores de cena, administradores e gerentes: uma burocracia ${ }^{165 "}$. Contudo, a festa possui em seu cerne o caráter disruptivo que é comum à revolta e à poesia. É graças a esta liberdade que a experiência da outridade se torna possível em seu seio. Se se anulam as hierarquias pressupostas à sua organização, a celebração não encontra limitações do ponto de vista social e político. A festa deve ser compreendida, então, como uma suspensão temporária dos consensos e dos ditames sociais que regem a vida pública. Ademais, é lícito pensar que sem a festa, o próprio poder público talvez não encontrasse salvaguardas e legitimidade em sua imposição, isto é, sem seus respiradouros de liberdade e zonas de ação onde a moralidade pública se encontra, se não inexistente, levemente suspensa ou acinzentada pelo terreno amorfo da ambiguidade que rege toda celebração.

Entretanto, mais do que isso, a festa será uma experiência temporal outra, isto, é, fundadora da figura do outro, da outridade. Em Sor Juana, Paz diz:

“celebração dos princípios que se supunha haverem dado o ser à sociedade e das figuras em que encarnavam esses princípios; participação de cada grupo e

\footnotetext{
${ }^{164}$ Id. Sor Juana Inés de la Cruz ou As armadilhas da fé. Trad. Wladir Dupont. São Paulo: Ubu Editora, 2017. p. 375.

165 Ibidem.
} 
de cada elemento numa totalidade que englobava todas as diferenças e anulava todas as hierarquias. Também celebração do Outro, o divino, e participação em outra realidade, a ultraterrestre".

Quando fazia menção ao que era ou é da ordem supraterrena, Paz sempre faz questão de deixar explícito que está se referindo ao aqui e agora. Para o autor, pensar a religiosidade, em seu sentido mais humano, é compreender um tipo de experiência que se dá à luz do dia e no cotidiano, assim como presumiam e defendiam os surrealistas, onde o elemento primordial é a reconciliação das partes fraturadas que compõe nossa disjunção primordial: o nascimento. Ainda em Sor Juana, Paz explica que a nossa busca pelo outro também impera na nossa prática como leitores: ler é, neste sentido, procurar de forma obstinada o nosso lugar de origem e reconhecimento. Para explica-lo, Paz se vale de uma explicação psicanalítica:

\footnotetext{
"no mundo pré-natal, desejo e satisfação são uma só coisa; o nascimento significa sua disjunção e nisso consiste o castigo de haver nascido. Nesse castigo começa também a consciência de ser: sentimos nosso eu como sensação de supressão do outro ${ }^{166 \prime \prime}$.
}

Para Paz, a primeira forma que encontramos de aplacar esta falta, esta disjunção originária, que marca a separação binária entre desejo e satisfação, é o leite materno. De forma similar, o poeta afirma que esta ausência originária, de onde deriva a metáfora "devorar com os olhos", dado o deslocamento do desejo da boca para os olhos, é replicada (numa metáfora de segunda ordem) na leitura. Assim, "o leitor devora com os olhos o leite da sabedoria e restabelece, precariamente, na esfera da imaginação e do

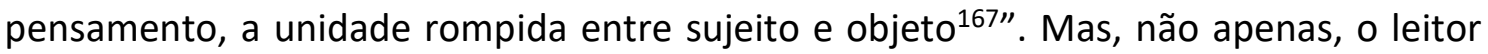
estabelece uma analogia entre este leite que nutre e aplaca sua fratura original e o

\footnotetext{
166 Ibidem. p. 105.

167 Ibidem.
} 
cosmo estrelado: por isso, a página, o texto vivo, é o duplo do cosmo. Mais especificamente, o nosso cosmo visível, a Via Láctea, sugerida por Paz no trecho:

\footnotetext{
“Desde o princípio do princípio o homem viu no céu estrelado um corpo vivo regado por rios de leite luminoso e ígneo; a essa visão, que faz do cosmo um imenso corpo feminino, junta-se outra: as estrelas e constelações associam-se e combinam-se no espaço celeste e assim traçam figuras, signos e formas ${ }^{168 "}$.
}

Outrossim, poderíamos inferir que associação do leite à galáxia Via Láctea e à página se dá pela cor branca ou blanca, cujo significado original remete a alvo/sentido. Ou seja, assim como em Mallarmé, o branco da página ressurge para conferir sentido à busca pelo outro significado das coisas e, para Paz, para a reposição dos cacos e fragmentos cuja disjunção original fraturou. Cabe dizer que a festa é uma destas experiências de reposição, pois não apenas congrega as pessoas no mesmo espaço de celebração e rito, mas porque também segue o calendário astronômico, expressão do tempo rítmico do mito: "tempo que revive o berço ninado pela maré do existir ${ }^{169 " . ~}$

Ao final do segundo capítulo, Paz dirá que Sor Juana, apesar de buscar atingir o conceito em muitas de suas obras, dentre poemas, vilancetes e loas, esbarrará na imagem e sua proeminência que se deixa deslizar pela torrente temporal que a todos arrasta: "embora a essência do mundo seja ideal, intelectual, as aparências flutuam na corrente temporal e nela desaparecem. [...] O conceito brilha por um instante sobre a página-espelho e se desvanece: como tudo e todos, é tempo que se dissipa ${ }^{170 " . ~ E m ~}$ suma, o reflexo do espelho, bem como as suas reflexões, estão fadadas a desaparecer no tempo, uma vez que a trajetória heroica de Sor Juana será a da heroína que, ao conquistar o conhecimento, ao se aproximar da excelência, tem, ao final da vida, de abandonar coercitivamente este caminho, como (para valermo-nos da metáfora anteriormente aludida) uma criança que, ao enfrentar o desmame, vê-se retirada no único claustro onde se sentira segura num universo de ameaças. Por isso, a resignação

\footnotetext{
168 Ibidem.

169 Ibidem.

170 PAZ, Octavio. Ibidem. p. 283
} 
e o silêncio - para não citar a mortificação a que se submeteu, ao cuidar de enfermos da epidemia que assolava o Vice-Reinado da Nova Espanha em sua maturidade.

Juana Inés também estabelece uma correspondência entre o Tempo e a música, a qual é considerada um "hieróglifo do tempo ${ }^{171 " . ~ E s t a ~ c o r r e l a c ̧ a ̃ o ~ s e ~ s u s t e n t a ~ a t r a v e ́ s ~}$ de uma prova, onde afirma a correspondência entre o signo Sol, as notas musicais e as horas do dia:

\footnotetext{
"sua máxima, "de doze partes composta", é o Dia - as horas são as colcheias enquanto a Noite é a "máxima pausa", também composta de doze intervalos. E tem mais: na "circular carreira" dos signos zodiacais - "até seu nome concorda com a música" -, o Sol sobe pelos seis primeiros e desce pelos outros seis até completar quatro tempos ou estações ${ }^{172 "}$.
}

Sor Juana não o diz, tampouco Paz, mas esta prova pode ser lida como uma analogia da música à ritmicidade do tempo cíclico, originário dos calendários, apesar da hegemonia do tempo cristão - retilíneo, linear e finito. Contudo, o movimento do Sol é ascendente e descendente, morre, mas renasce. Se a música é uma arte cuja percepção depende da duração, à medida em que avança no tempo e as notas se sucedem, há sempre a possibilidade de repeti-la mais uma vez, reiniciando o ciclo. Portanto, se a música, para Juana Inés é hieróglifo do tempo, certamente este hieróglifo admite certa pluralidade temporal, como nos sugere sua circularidade. Obviamente, quanto ao tempo, a dificuldade de defini-lo explica porque este conceito, do qual Juana Inés devia ter ciência da investigação promovida por Agostinho nas Confissões, aparece correlacionado a uma imagem. Assim como Octavio Paz, Sor Juana Inés de la Cruz se vale do que podemos chamar "conceptismo imagético", pois seu pensamento podia ser vislumbrado pela dupla operação, em que estão articulados no mesmo discurso/verso conceitos e imagens. Paz reconhece este método no pensamento da poetisa e, ao fazê-lo, parece reconhecer seu modus operandi: "Podemos até dizer que seu conceptismo parte quase sempre de uma imagem visual ou desemboca em outra. Quando não vê, evoca e

\footnotetext{
171 Ibidem.

172 Ibidem.
} 
fantasia: vê com a memória e com os olhos desse espírito fantástico que olha quando o artista fecha os olhos ${ }^{173 \prime}$. Em ambos os casos, a fantasia, seja no uso que Juana Inés faz ou no uso de seu próprio biógrafo, quando poeta (se é que deixa de sê-lo, em algum momento), é o que possibilita a consolidação de um real: intermediário entre o espiritual e o sensível. Por isso, Paz dirá: “Aristóteles havia dito que o homem tem necessidade das imagens "para pensar no tempo o que está fora do tempo ${ }^{174 " .}$

Poderíamos acrescentar: para compreender as realidades que parecem escapar ao próprio espaço e tempo. Hoje sabemos da operacionalidade estética das imagens científicas e como elas possuem importância na nossa compreensão contemporânea do cosmo. Se as imagens foram importantes, "desde o princípio do princípio" para a compreensão do cosmo e, por isso, sempre figuraram em abundância no pensamento poético, hoje não poderia ser menos diferente. Para Merleau Ponty, "a visão é uma experiência existencial que não coloca o pensamento à frente, mas enfatiza a relevância do sensível175". Por esta razão, "quando vemos algo, nossa relação com o que vemos não é intelectual, não é exploratória de conceitos que expliquem ou justifiquem o que vemos. Vemos como s olhos que são nosso corpo ${ }^{176 ",}$, sugere Cristina Bonfiglioli acerca da importância atribuída à construção científica e coletiva das imagens do que possuímos de mais novo em termos de cosmologia/astronomia: a imagem dos arredores do buraco negro no centro da galáxia M87. Ou seja, ainda que nossas concepções de tempo e espaço tenham mudado radicalmente, a máxima aristotélica, da qual Paz e Sor Juana parecem ser signatários, segue: nosso recurso às imagens é não apenas um dispositivo ou um recurso estético, mas um depositário do que ainda podemos chamar maravilhoso ou, se utilizarmos termos pazianos, outro: ainda que este outro seja um buraco negro do qual pouco ou nada sabemos.

Voltando à metáfora cósmica, o leite, podemos dizer que este alimento não apenas dá a vida e a sustentação da cria, mas também dá o conhecimento ao iniciado nas aventuras da sabedoria, pois, como já dissemos: leite, constelação e leitura são

\footnotetext{
173 Ibidem. p. 264.

174 Ibidem. p. 451.

${ }^{175}$ BONFIGLIOLI, Cristina Pontes. O dar a ver de um buraco negro In Zum: revista de fotografia. São Paulo: Instituto Moreira Salles, 10 semestre 2019. Disponível em: https://revistazum.com.br/radar/buraconegro/ (Acesso em 2 de junho de 2019).

176 Ibidem.
} 
metáforas interligadas pela analogia. Desta maneira, ler também é um ato que, assim como a festa, nos põe em procura do outro, em seu sentido mais amplo, onde a leitura dos signos é a contemplação da constelação de destinos, séries históricas e universos humanos possíveis através de um talvez. Quando esta busca se torna coletiva, ela se torna festa ou celebração. Celebrar o outro, na sua especificidade, na compreensão de sua natureza, é fazê-lo, ainda que através de ritos, mitos e símbolos, no agora, no momento em que o tempo se encarna. Por isso, ao fazer menção a um dos vilancetes escritos por Sor Juana Inés de la Cruz, gênero de extrema importância na obra da monja, Paz transcreverá em sua biografia o que considera os versos de onde "brota do fundo do tempo outro tempo como exalação ${ }^{177 " \text { : }}$

\author{
"iUn instante me escuchen, \\ que cantar quiero \\ un instante que estuvo \\ fuera del tiempo ${ }^{178 ! "}$
}

Exalação que pode ser compreendida como uma forma de manifestação, de desocultar e deixar vir à tona. Nestes versos, é possível aferir que convergem tempo e festa, uma vez que ao consagrar o instante e declarar poeticamente acerca de sua natureza, Sor Juana não apenas elenca que existe um tempo além do tempo, além do cotidiano, em que é possível o canto, mas funda o espaço próprio em que ele encontra terreno para tornar-se um evento: a festa. Ora, se Juana Inés realiza este movimento, é possível pensar que o tempo, interlocutor natural das obras de Octavio Paz, também esteve presente nas obras da monja, inquirindo-a a todo instante. A festa, portanto, pode ser compreendida como uma das formas de exalação do tempo, pois é a irrupção do tempo presente enquanto instante descontínuo.

\footnotetext{
177 PAZ, Octavio. Ibidem. p. 375.

${ }^{178}$ CRUZ, Sor Juana Inés de la. Vilancete 279. In ibidem. p. 379.
} 
Mas, para Paz é necessário que pensemos o tempo não apenas através de sua aparição, mas sim da transfiguração que, ao nos envolvermos com ele, realizamos entorno de sua natureza. Em O Labirinto da Solidão, Paz diz que

\footnotetext{
“o solitário mexicano ama as festas e as reuniões públicas. Tudo é oportunidade para reunir-se. Qualquer pretexto é bom para interromper a marcha do tempo e celebrar homens e acontecimentos com festejos e cerimônias. Somos um povo ritual ${ }^{179 \prime \prime}$.
}

Neste capítulo, Todos os santos, finados, Paz analisa a festa a partir de sua relação com a temporalidade e com os ditames morais e políticos de uma sociedade autoritária, e hierarquizada como a mexicana. Mas, qual seria a importância de um instante da festa? Ora, em primeiro lugar, devemos levar em conta que o México é um país cuja pluralidade étnica não é a única heterogeneidade a ser ressaltada, pois junto das raças e línguas diferentes, existem também os vários níveis históricos, onde ideias contraditórias ocupam e disputam o mesmo espaço. Não raro, esta sobreposição é violenta, como o caso da pirâmide: “Às vezes, como as pirâmides pré-cortesianas que quase sempre ocultam outras pirâmides, numa mesma cidade ou numa mesma alma se misturam e se sobrepõem princípios e sensibilidades inimigos ou distantes ${ }^{180 "}$. Por conta dessa correlação de forças, a imposição da festa enquanto evento ocorre como uma convergência da comunidade, onde o mexicano, ensimesmado e fechado, abre-se ao outro. O evento coletivo é um momento de congregação e excessos, marca da ambiguidade e estabelecimento das pontas que conectam os pontos extremos da contradição. Ou seja, trata-se um fenômeno do tempo cíclico. Paz diz que o dia de festa

\footnotetext{
“é uma pausa; efetivamente, o tempo acaba, extingue-se. Os ritos que celebram sua extinção estão destinados a provocar seu renascimento: a festa
}

\footnotetext{
179 Paz, Octavio. O Labirinto da Solidão. Trad. Ari Roitman e Paulina Wacht. São Paulo: Cosac Naify, 2014. p. 49.

180 Ibidem.
} 
de final de ano é também a do ano novo, a do tempo que começa. Tudo atrai o seu contrário ${ }^{181 "}$.

Paz compreende a festa como compreende a revolta, se entendida como manifestação contra a ordem, detentora do princípio que desorganiza e instaura o caos. Por conta dessa totalidade desorganizadora, é impossível ao participante da festa não partilhar da temporalidade que lhe rege. A festa, seja a de matriz nacional ou religiosa, tem a capacidade de unir no mesmo espaço o asceta e o glutão, o pecador e o beato. Trata-se, para Paz, de "um fato social baseado na participação ativa dos presentes ${ }^{182 " . ~ A d e m a i s, ~}$ as festas, assim como a revolta, funcionam como o ponto de uma ruptura de uma série aberta. A correspondência entre festa e revolta é marca de uma temporalidade autônoma que modifica a forma como nos relacionamos com o outro e a sociedade.

Por isso, as experiências políticas de Maio de 1968 e as dos anos que a ele se seguiram podem ser compreendidas como rupturas violentas com o poder e a moralidade estabelecidas pela tradição. Os motes de "imaginação no poder" e da juventude nas ruas, reforçados pela visibilidade da experiência francesa, encontraram seus correlatos em diversas partes do mundo. Para Paz, se interpretássemos estas experiências como uma irrupção espontânea da revolta ou como uma manifestação instantânea da rebelião motivada pelo agora, estaríamos no caminho certo. No Postscriptum de $O$ Labirinto da Solidão, que contém duas conferências de Octavio Paz apresentadas em Austin, na Universidade do Texas, o autor versa sobre a própria obra em consonância com os acontecimentos políticos ocorridos naqueles anos e começa com uma crítica ao progresso:

\footnotetext{
"a filosofia do progresso mostra enfim o seu verdadeiro rosto: um rosto em branco, sem feições. Agora sabemos que o reino do progresso não é deste mundo: o paraíso que nos promete está no futuro, num futuro intocável, inatingível, perpétuo. O progresso povoou a história com as maravilhas e os
}

\footnotetext{
181 Ibidem. p. 53.

182 Ibidem.
} 
monstros da técnica, mas desabitou a vida dos homens. Deu-nos mais coisas, não mais ser ${ }^{183 "}$.

A crítica do progresso é acompanhada de uma defesa do agora, do presente enquanto experiência do tempo vivo. Ao decretar a sua morte, Paz vislumbra o resgate do sentido do presente em nossa experiência diária, em nossa vida voltada às experiências dotadas de sentido, pois este tempo "homólogo das ideias de progresso e história, sempre lançado em direção ao futuro; o tempo do signo não-corpo, empenhado em dominar a natureza e reprimir os instintos [...]: nosso tempo - termina ${ }^{184 \prime \prime}$.

Enquanto interrupção do contínuo temporal e do ritmo em marcha rumado ao futuro, no que consiste a irrupção do agora instantâneo? Para Benedito Nunes, na filosofia contemporânea, devemos nos ater a duas contribuições que versaram sobre um conceito de história demarcado pela ideia de interrupção:

\footnotetext{
“pelo que sei, em nossa época, dois pensadores, pelo menos, Heidegger e Walter Benjamin, conceberam, dissentindo do historicismo, uma História descontínua e interruptiva, o segundo, por intermédio de um tempo-agora (Jetz-Zeit), "concebido como parada messiânica do ocorrente", e o primeiro por intermédio do instante (Augenblick) da temporalidade autêntica, em que o Dasein experimenta sua própria finitude, estendida, ininterruptamente, do nascimento à morte (o Dasein não tem um fim que o faça cessar, simplesmente, uma vez atingido; ele existe finitamente); e, projetando-se adiante no Cuidado, ele assume livremente como destino sua historicidade original. O homem, então, não cai no tempo, mas existe como temporalização originária ${ }^{185 ”}$.
}

Mas, para Paz, há um motivo claro pelo qual podemos compreender a forte adesão da juventude a este movimento político predominante no final dos anos 60: o retorno do corpo à voga, à pauta do dia. Trata-se, portanto, de um retorno da palavra tornada tabu

\footnotetext{
183 Ibidem. p. 202.

${ }^{184}$ PAZ, Octavio. Conjunções e Disjunções. Trad. Lúcia Teixeira Wisnik. São Paulo: Perspectiva, 1979. p. 133.

185 NUNES, Benedito. No tempo do niilismo e outros ensaios. São Paulo: Edições Loyola, 2012. p. 12.
} 
no Ocidente, graças a seu caráter insubordinável, isto é, não-dócil, não-disciplinável: o Prazer. Esta parte da humanidade, que fora subjugada pela ideologia do progresso bem como pela austeridade da economia sexual do calvinismo, na base do sistema capitalista, regressa como manifestação política: os afetos, as relações sexuais, as múltiplas formas de se relacionar, a homossexualidade, a existência do prazer feminino, bem como as mais diversas pautas classificadas como identitárias são, para Paz, manifestações de formas de ser e existir que foram demasiado escamoteadas por ditames imperativos de uma vida moral e ascética num sentido em que a disjunção corpo e não-corpo encontrava sua máxima polarização.

Neste sentido, Paz associa os acontecimentos deste período a uma herança que provém também dos movimentos poéticos que sempre colocaram o Amor e o Prazer no centro da atividade vital: o romantismo e o surrealismo. Se o surrealismo, ou a forma de sensibilidade geral que assim chamamos, bem como o romantismo, possui um "poder de transformação" e a "capacidade de atravessar, subterraneamente, a superfície histórica e aparecer de novo ${ }^{186 "}$ é porque é capaz de, à sua maneira, transformar o tempo. Estas inclinações poéticas surgem como inclinações passadas que se comensuram no presente, transmutando-o. Ora, mas se o tempo se transforma, é conveniente perguntar: do que é feito? Qual a sua composição? Quais as visões históricas que temos do tempo e como elas se chocam, dialogam, confrontam-se? Afinal, não é possível que a realidade histórica se transforme sem que haja, substancialmente, uma alteração da imagem de tempo que a acompanha e diante da qual toda forma de produção social, cultural e política se constrói. Sobre esta ideia, diz Giorgio Agamben:

\footnotetext{
"toda experiência da história é sempre acompanhada de uma certa experiência do tempo que Ihe está implícita, que a condiciona e que é preciso, portanto, trazer à luz. Da mesma forma, toda cultura é, primeiramente, uma certa
}

${ }^{186}$ PAZ, Octavio. O Arco e a Lira. Trad. Ari Roitman e Paulina Wacht. São Paulo. Cosac Naify. 2012. p. 255. 
experiência do tempo, e uma nova cultura não é possível sem transformação desta experiência ${ }^{187 \prime \prime}$.

Esta correlação entre experiência histórica e experiência temporal está presente em Octavio Paz. Para o mexicano, a transfiguração do tempo se dá pelos sujeitos, pelas formas artísticas e pelas transformações na tradição, contudo, toda tradição, toda forma artística e toda subjetividade está ancorada numa imagem de tempo. Se pensarmos em uma forma artística que o influenciou e à qual Paz faz associações à experiência política da Revolta, o Surrealismo, poderíamos pensar como esta correlação se dá de maneira mais clara.

Sensibilidade apaixonada e sensibilidade crítica, o surrealismo aparece no interior de uma tradição que reage à instrumentalização do mundo e à redução deste sob os ditames utilitários e reificantes da razão e dos seus operadores conceituais e analíticos. É diante da confiança nas faculdades do entendimento e da capacidade humana de calcular, medir e quantificar, próprias da ratio e presentes no seio do espírito científico, que o surrealismo planta a sua centelha de desconfiança e se apresenta como uma demanda de concepções do mundo alheias aos imperativos da razão. Mais do que isso, não se pode reduzir o surrealismo a uma mera escola poético-filosófica ou conjunto de doutrinas específicas que encamparam posturas no campo da arte. Como afirma Michael Lowy na abertura de seu livro sobre o movimento,

\footnotetext{
“o surrealismo não é, nunca foi e nunca será uma escola literária ou um grupo de artistas, mas propriamente um movimento de revolta do espírito e uma tentativa eminentemente subversiva de re-encantamento do mundo, isto é, de restabelecer, no coração da vida humana, os momentos "encantados" apagados pela civilização burguesa: a poesia, a paixão, o amor-louco, a

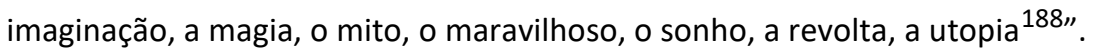

\footnotetext{
${ }^{187}$ AGAMBEN, Giorgio. Tempo e História: crítica do instante e do contínuo In Infância e História: Destruição da experiência e origem da história. Trad. Henrique Burigo. Belo Horizonte. Ed. UFMG/Humanitas. 2012. p. 109.

188 LOWY, Michael. A estrela da manhã: surrealismo e marxismo. Trad. Eliana Aguiar. Civilização brasileira. Rio de Janeiro. 2002, p. 9.
} 
Conceituar é recortar a realidade, por isso o surrealismo converte o homem no escape a esta cisão e o abre à pluralidade de sentidos e interpretações. Em Estrela de três pontas, Paz escreve "O surrealismo fez sua a máxima de Novalis: "O homem é imagem". E a recíproca também é verdadeira: a imagem encarna no homem"189. Ao fazer da realidade e do homem imagens, o surrealismo conferiu à poesia o papel de interpretar e transformar o real. Por isso, quando ensaia definir o surrealismo, Paz chega à conclusão de que este movimento só pode ser uma "atitude do espírito humano" "possivelmente, a mais antiga e constante, a mais poderosa e secreta" ${ }^{190}$. Marca de uma persistência, o surrealismo também é uma "direção do espírito191", aquela que será depositária das paixões e de experiências que escapam à nossa capacidade de objetivar e compreender racionalmente, capaz de alterar profundamente o estado no qual nos encontramos para nos levar a um

\footnotetext{
"estado de insubmissão, de negatividade, de revolta, que retira sua força positiva erótica e poética das profundezas cristalizadas do inconsciente, dos abismos insones do desejo, dos poços mágicos do princípio de prazer, das músicas incandescentes da imaginação"192.
}

O que faz o surrealismo - esta tendência que nos transporta ao passado mais vivo (apesar de, muitas vezes, inacessível) ou, se se preferir, à nossa origem - são os poderes humanos de criação, através da imaginação e do universo onírico (fantástico e capaz de nos deixar suscetíveis ao espanto da realidade), além, é claro, de outro fator primordial: a memória. Este princípio é habitante de nós mesmos e retorna apenas quando não estamos alienados do que os artistas deste período chamaram de a "verdadeira vida193".

\footnotetext{
189 PAZ, Octavio. A estrela de três pontas in A busca do presente - e outros ensaios. Org. e trad. Eduardo Jardim. Rio de Janeiro: Bazar do Tempo, 2017. p. 43.

190 Ibidem, p. 44.

191 PAZ, Octavio. O Arco e a Lira. Trad. Ari Roitman e Paulina Wacht. São Paulo: Cosac Naify, 2012. p. 255.

192 LOWY, Michael. A estrela da manhã: surrealismo e marxismo. Trad. Eliana Aguiar. Civilização Brasileira. Rio de Janeiro. 2002. p. 10.

193 Ibidem, p. 42.
} 
Esta vida, o poeta deve buscá-la nos meandros do Ser, onde se encontra a chave de formas de experiência autênticas, que possam revelar as potencialidades do ser humano enquanto aberturas e possibilidades de ser e existir. Porém, a vida plena não está fora de nós, num além-tempo ou num além espacial, mas no "aqui e agora", de todos os dias. Por isso, Paz classifica o surrealismo menos como uma poética, mas mais como uma postura diante da vida e do cotidiano. É graças a esta concepção de vida que o corpo, enquanto espontaneidade da experiência, está no centro desta corrente da sensibilidade humana.

Entretanto, convém apontar que o surrealismo não apenas intentou insurgir-se contra os princípios da razão nas diretrizes da vida pessoal, mas enveredou por uma trilha política que, na visão de Paz, culminou em seu fracasso neste campo. Em O Arco e a Lira, ele diz que

\footnotetext{
"o surrealismo não apenas se proclamou a voz poética da Revolução, mas também identificou esta última com a poesia. A nova sociedade comunista seria uma sociedade surrealista, na qual a poesia circularia pela vida social como força perpetuamente criadora. Mas na realidade histórica essa nova sociedade já havia gerado seus mitos, suas imagens e um novo sagrado. Antes de nascer o culto aos chefes, já haviam surgido os guardiões dos livros santos e uma casta de teólogos inquisidores ${ }^{194 \prime}$.
}

O fracasso se deu porque, ao encarnar a revolução, o surrealismo oficializou-se no corpo do Estado, o que o impediu de desenvolver-se artística e politicamente como previamente se pensava, pois, o preço a ser pago foi o da Liberdade, justamente uma das três pontas que compõem o triângulo "incandescente" deste movimento. Sem liberdade artística, o surrealismo protocolou-se como arte oficial do Estado, ou seja, propaganda. Não apenas, neste contexto, cabe ressaltar a relação extremamente problemática da poesia diante da religião e da revolução.

Uma vez desfeitas as sociedades fechadas, resta nas sociedades abertas, compostas por refugiados de todos os lugares, o fardo contínuo da sua falta de sentido e da nostalgia pela idade do ouro que aquelas sociedades antigas representavam. Nas

194 PAZ, Octavio. Op. Cit., 2012, p. 254 
novas sociedades, a criança possui a capacidade de se esquecer de si mesma diante do brinquedo e do caráter mágico da palavra, porém, uma vez dissuadida de seus próprios poderes encantatórios (graças à consciência em seu progresso e ao imperativo consciente da necessidade de estar no mesmo sentido que o progresso), encontrara na adolescência a solidão como o substrato último e a condição inelutável de sua existência, uma vez abandonada neste universo laico que é a vida. Quando adulta, será o trabalho o substituto do brinquedo, mas a ferida de saber-se sozinho dificilmente se fechará. Octavio Paz aponta a poesia e o erotismo (pensando nas experiências de Lawrence, Sade, Bataille, Fourier, etc) como caminhos de reconciliação entre o homem e a realidade. Quem os invoca é o poeta, que se pretende o fundador de outra realidade, a da presença. Encontrando, assim, seu conflito com a religião, pois "tira espaço do sacerdote e a poesia torna-se uma revelação rival da escrita religiosa ${ }^{195 ", ~ o ~ p o e t a ~ s e ~}$ coloca como o defensor de um tempo que não é o do progresso, do desenvolvimento e da utopia, despertando aqui seu conflito com os revolucionários (tome-se o exemplo de Maiakovski), ainda que exorte a palavra "revolução". Não por outro motivo são eles tão perseguidos pelo mundo moderno, construído sobre os imperativos da razão científica e da ética do trabalho pelo trabalho, pois "uma das funções centrais da poesia é mostrarnos o outro lado das coisas, o maravilhoso cotidiano: não a irrealidade, mas a prodigiosa realidade do mundo196". Diante disso, o poeta é marginal tanto na religião como no Estado: por isso, coaduna-se facilmente à festa e à revolta.

Portanto, se considerarmos a transformação da sensibilidade "surrealista" uma transformação histórica significativa, devemos partir do pressuposto que ela significa, também, uma transformação de nossa experiência do tempo. Ora, se Paz consegue enxergar nesta experiência, que Benjamin classifica como o último instante de inteligência europeia, o estofo da agoridade e do instante, verá tão mais realidade nas experiências dos lugares onde o surrealismo nunca se fez necessário ${ }^{197}$ : o Oriente.

\footnotetext{
195 Id, Filhos do Barro, Trad. Ari Roitman e Paulina Wacht. São Paulo: Cosac Naify, 2012, p. 55 196 Ibidem. p. 59.

197 Em Conjunções e Disjunções, Paz constatará essa antecedência criativa, ao afirmar que "Durante a Exposição Surrealista dedicada ao erotismo, há alguns anos, houve uma cerimônia parecida: um festim no qual a mesa era uma jovem despida. Os surrealistas ignoravam o antecedente indiano. As imagens encarnam" (Op. Cit., 1979, p. 71).
} 


\title{
À beira da outra margem: Oriente e Ocidente
}

Ao pensar a Índia em Conjunções e Disjunções, Paz também fará uma menção à festa e sua correlação à rebelião. Para o autor, o que vivemos neste período curto, chamado século XX, foi uma manifestação espontânea que, dada as diferenças conjunturais, expressaram, cada uma à sua maneira, uma demanda pelo presente. A este respeito, dirá que

\footnotetext{
"a forma extremada da modernidade na arte é a destruição do objeto; esta tendência, que se iniciou como uma crítica da noção de "obra de arte", culmina agora numa negação da própria noção de arte. $\mathrm{O}$ círculo se fecha, a arte deixa de ser "moderna": é um presente instantâneo. Quanto à sexualidade e ao tempo: o corpo nunca acreditou no progresso, sua religião não é o futuro, mas o hoje. A emergência do presente como valor central é visível em muitas zonas da sensibilidade contemporânea: é um fenômeno nítido ${ }^{198 "}$.
}

Podemos afirmar que esta crença do corpo antecede e muito os escritos de Octavio Paz. Em seus escritos, Giorgio Agamben já reconhece em Aristóteles esta tendência a atribuir ao corpo uma outra perspectiva em relação ao tempo. Em Infância e História, o italiano diz que

\begin{abstract}
“existe, porém, uma experiência imediata e disponível a todos em que uma nova concepção do tempo poderia encontrar seu fundamento. Esta experiência é algo tão essencial ao humano que um antigo mito do Ocidente faz dela pátria original do homem. Trata-se do prazer. Aristóteles já havia percebido que ele não é homogêneo à experiência do tempo quantificado e contínuo. "A forma (eidos) do prazer - escreve na Ética a Nicômano - é perfeita (téleion) em qualquer momento"; e acrescenta que o prazer, diversamente do movimento, não se desenrola em um espaço de tempo, mas é "a cada instante um quê de inteiro e de completo" [...] Isto não significa que o prazer tenha seu lugar na eternidade. A experiência ocidental do tempo está cindida em eternidade e
\end{abstract}

198 PAZ, Octavio. Conjunções e Disjunções. Trad. Lucia Teixeira Wisnik. São Paulo: Perspectiva, 1979. p. 127. 
tempo linear contínuo. O ponto de divisão, através do qual estes se comunicam, é o instante como ponto inextenso e inapreensível ${ }^{199 \prime \prime}$.

O reconhecimento do instante como ponto indiviso nos remete à própria obra do autor que fundou a concepção de tempo enquanto correlato do espaço, concepção criticada tanto por Heidegger quanto por Bergson. Por conta disto, para Paz as experiências de tempo da segunda metade do século XX podem nos indicar que essa demanda pelo presente é, na verdade, uma retomada de reivindicações do corpo. Afirmamos que é uma retomada, pois, para o autor, é possível ver nesta pauta uma continuidade da visão e imagem de mundo constituída no pensamento de românticos e surrealistas, destarte os projetos de futuro que estes, em alguma medida, tenham defendido em suas trajetórias, como já indicamos.

Momentos de prazer do corpo são destes que são como instantes qualitativos, incomensuráveis, cuja duração obedece a um ritmo discernível segundo o movimento contínuo das palavras, convertidas em imagens ou, muitas vezes, silenciadas diante da nossa incapacidade de verbalizá-las. A compreensão da festa como instante analógico à revolta e à poesia deve levar em conta que, ao se posicionar como experiência do tempo, a festa reivindica seu lugar enquanto experiência do corpo. Em Conjunções e Disjunções, Paz afirma que

\footnotetext{
“a universalidade da rebelião juvenil é o verdadeiro signo dos tempos: $O$ sinal da mudança de tempo. É claro que essa universalidade não deve fazer-nos esquecer que o movimento da juventude tem um sentido diverso em cada país: negação da sociedade de abundância e oposição ao imperialismo, à discriminação racial e à guerra [...] nos países "socialistas" do Este europeu; oposição contra o imperialismo ianque e os opressores locais na América Latina ${ }^{200 \prime \prime}$.
}

\footnotetext{
199 AGAMBEN, Giorgio. Tempo e História: crítica do instante e do contínuo In Infância e História: Destruição da experiência e origem da história. Trad. Henrique Burigo. Belo Horizonte. Ed. UFMG/Humanitas. 2012. p. 125.

200 PAZ, Octavio. Ibidem.
} 
Reconhecendo a sua pluralidade política e reconhecendo nesta demanda pela temporalidade presente a luta pela visibilidade de uma forma de existir e experienciar o tempo também plural, Paz inferirá a raiz de todas estas manifestações no desenrolar histórico da própria modernidade.

Quando pensamos o fenômeno das revoltas, pensamos também uma reivindicação ucrônica, isto é, uma demanda de como algo poderia ter sido. Para Foucault, em toda sociedade há "utopias que têm um lugar preciso e real, um lugar que podemos situar no mapa; utopias que tem um tempo determinado, um tempo que podemos fixar e medir conforme o calendário de todos os dias ${ }^{201 "}$. Se compreendemos a revolta como a demanda por um espaço que é absolutamente outro - ou contraespaços, diante do cotidiano que se oferece, injustamente, para todos nós, devemos compreendê-la também como uma postura que exige um recorte singular do tempo. A este tipo de demanda, Michel Foucault chamará "heterotopias". Estas heterotopias podem se configurar em sentidos distintos e novos, a ponto de considerarmos que toda sociedade "pode perfeitamente diluir e fazer aparecer uma heterotopia que constituíra outrora, ou então, organizar uma que não existisse ainda202". A heterotopia possui a peculiaridade de ser um espaço capaz de justapor - no mesmo recorte temporal - vários espaços originalmente incompatíveis. Com isto, podemos afirmar que a possibilidade de fazê-la surgir é uma atividade criativa, muitas vezes, motivada pela imaginação. Por isso, Foucault classificará assim certas criações do teatro, do cinema e mesmo espaços lúdicos, como o jardim oriental. Todas estas experiências espaciais - pois nos deslocam a este "outro lugar" -, onde, para usarmos a expressão de Breton, "la véritable existence est ailleurs ${ }^{203 ", ~ t a m b e ́ m ~ p e r f i l a m ~ o u t r a ~}$ experiência do tempo: "são parentes, se quisermos, das heterocronias ${ }^{204 "}$. Ou seja, as heterotopias foucaultianas possuem uma relação diferente com o tempo: eternidade, possibilidades de passado e, além disso, a temporalidade da festa. O autor diz que "há heterotopias que são ligadas ao tempo [...] ao modo da festa", isto é, festas que podem

\footnotetext{
${ }^{201}$ FOUCAULT, Michel. O corpo utópico, As heterotopias. Trad. Salma Tannus Muchail. São Paulo: N-1 Edições, 2013. p. 19.

202 Ibidem.

${ }^{203}$ BRETON, André apud PAZ, Octavio. Signos em Rotação. Trad. Sebatião Uchoa Leite. São Paulo. Perspectiva. 2009. p. 107.

${ }^{204}$ FOUCAULT, Michel. Ibidem. p. 25.
} 
se constituir como sistemas abertos ou fechados, uma vez que podem ser realidades postas apenas a iniciados ou ilusórias, uma vez que se ofertam como "livro aberto" e nos mantém fora. De toda forma, a heterotopia possui um caráter que é bastante visível na festa e, talvez, por isso Foucault considere que sua realização se dê por este "modo", que é a contestação - o que nos aproxima, naturalmente, do espírito de revolta. Para Foucault,

\footnotetext{
"é aí, sem dúvida, que encontramos o que de mais essencial existe nas heterotopias. Elas são a contestação de todos os outros espaços, uma contestação que pode ser exercida de duas maneiras: [...] criando uma ilusão que denuncia todo o resto da realidade como ilusão, ou, ao contrário, criando outro espaço real tão perfeito, tão meticuloso, tão bem-disposto quanto o nosso é desordenado, mal posto e desarranjado ${ }^{205 "}$.
}

Em suma, a partir disso, podemos visualizar que as festas, em seu caráter moderno, filhas da ironia e da analogia, podem manter este caráter contestatório. Festa e revolta são duas faces de uma mesma moeda que, na obra de Octavio Paz, possui um sentido contestador, mas que preserva uma função e uma capacidade fundadoras. Local da heterotopia, a festa é plural.

Neste sentido, para além da disputa ideológica que permeou toda a metade do século XX, o fenômeno das revoltas foi uníssono em ambos os blocos políticos da Guerra Fria. Por isso, no intuito de estabelecer uma explicação generalizante que explicasse esta tendência espontânea, Paz expõe, na mesma obra, o fato social de que

\footnotetext{
"todas essas instituições e sistemas constituem o que se chama a modernidade, por oposição ao mundo medieval. Todas elas são filhas do tempo linear e todas são negadas agora. A negação não vem do passado mas do presente. A dupla crise do marxismo e da ideologia do capitalismo liberal e democrático possui
}

205 Ibidem. p. 28. 
significação igual à da revolta do mundo subdesenvolvido e à da rebelião juvenil: são expressões do fim do tempo linear ${ }^{206 \prime \prime}$.

Independentemente da motivação ideológica, as revoltas que se sucederam neste período correspondem ao ocaso da modernidade que, por sua vez, pode ser compreendido como o ocaso do tempo linear, pois este, em sua aceleração, possibilitou o surgimento da tradição da ruptura, que se hipostasiou no interior das formas artísticas, dando resultado aos mais diversos 'ismos' da arte moderna.

Além disso, por considerá-la ritual, Octavio Paz crê que a experiência poética contém em si mesma uma espécie de força capaz de modificar a nossa percepção num sentido semelhante ao das experiências místicas, o que fortalece a aproximação entre a experiência poética e a da magia, como se pode compreender na citação a seguir:

\footnotetext{
“a operação poética não é diversa do conjuro, do feitiço e de outros procedimentos da magia. $\mathrm{E}$ a atitude do poeta é muito semelhante à do mago. Os dois utilizam o princípio da analogia; os dois agem com fins utilitários e imediatos: não se perguntam o que é o idioma ou a natureza, mas se servem deles para os próprios fins. Não é difícil citar outra marca: magos e poetas, ao contrário de filósofos, técnicos e sábios, extraem seus poderes de si mesmos ${ }^{207 \prime \prime}$.
}

Como já indicamos, esta relação é tão íntima que a poesia, dentre as mais diversas possibilidades da linguagem humana, é uma experiência capaz de nos colocar em contato com o próprio tempo, graças à sua natureza rítmica e imagética. Como o mago transmuta a natureza, o poeta transmuta o tempo no instante em que a poesia se realiza. E sobre esta possibilidade, em O Arco e a Lira, Paz afirma que se trata de algo que é própria da nossa condição humana, como fica claro, a seguir:

${ }^{206}$ PAZ, Octavio. Os Filhos do Barro. Trad. Ari Roitman e Paulina Wacht. São Paulo: Cosac Naify, 2013. p. 128.

207 PAZ, Octavio. O Arco e a Lira. Trad. Ari Roitman e Paulina Wacht. São Paulo: Cosac Naify, 2012 p. 60. 
“o tempo não está fora de nós, nem é algo que passa diante dos nossos olhos como os ponteiros do relógio: nós somos o tempo, não são os anos que passam, mas nós que passamos. O tempo possui uma direção, um sentido, porque ele é nós mesmos. O ritmo realiza uma operação contrária à de relógios e calendários: o tempo deixa de ser medida abstrata e volta a ser o que é: algo concreto e dotado de direção. Contínuo emanar, perpétuo ir além, o tempo é um permanente transcender-se. Sua essência é o mais - e a negação desse mais ${ }^{208 \prime \prime}$.

O poeta mexicano considera a palavra poética, a palavra rítmica, como fundadora de um instante incomensurável. Esta palavra nos remete à origem e ao fluir temporal incessante, como a pedra fundamental da afirmação de uma nova imagem de tempo ou das temporalidades plurais, que regem as mais diversas sociedades. Destarte este caráter social, ficou claro que Paz fala de uma temporalidade pura que é própria do ser humano e que é marca fundamental de sua condição, revelada pela nossa propensão a estabelecer analogias entre as coisas mais díspares.

No Prefácio de Os Filhos do Barro, Octavio Paz afirma que esta operação poética é capaz de inverter e contradizer o tempo. Ao mesmo tempo que nos coloca em contato íntimo com o fluir próprio de nossa condição, a atividade poética nos possibilita transfigurá-lo. Paz afirma que o tempo na poesia "passa de uma forma diferente de como passa na história ou no que chamamos de vida real ${ }^{209 "}$ e, por conta disso, cria a anti-história. Entretanto, nem por isso podemos afirmar que o poema ou mesmo a poesia em geral não são produções exclusivamente históricas. Não há como afirmar que estas não refletem o espírito de uma época. Cabe discutir qual é o grau de historicidade da poesia e como ela, ao transformar o tempo, altera, por sua vez, a própria história. A forma como nos ligamos à história é uma relação com o devir que se assemelha àquela que estabelecemos com o tempo, dadas as devidas ressalvas e diferenciações. Nesse sentido, para Octavio Paz, seria a afirmação do tempo histórico distinta de uma afirmação do fazer poético? Ao associar a poesia à revolta, Paz nos indica que não.

\footnotetext{
208 Ibidem. p. 64.

${ }^{209}$ PAZ, Octavio. Os filhos do barro. Trad. Ari Roitman e Paulina Wacth. São Paulo: Cosac Naify, 2013. p. 9.
} 
Nesta mesma obra, Os filhos do barro, Paz se ocupa da noção de modernidade e a possibilidade de encararmos seu iminente fim. Dizemos iminente, pois, para o poeta, o período em que vivemos já tem de arcar com as consequências de um suposto esgotamento da imagem de tempo teleológica, linear e progressiva, cujo sentido remete ao futuro, local depositário de todos os tipos de utopia e possibilidades de ser e sentido, próprios da modernidade. A Revolta, aludida anteriormente, é apenas um dos sintomas deste esgotamento irreversível e que fere, diretamente, o projeto moderno. A ideia de tradição moderna - por mais paradoxal que possa ser, pois envolve duas noções díspares, apesar de complementares - se marcou pela capacidade de negar o passado para afirmar algo novo em seu local, que não tardava a envelhecer. Esta modernidade das rupturas sucessivas foi o que, para Paz, se transformou em tradição da ruptura, referida por nós agora há pouco.

A tradição moderna se alimenta da "paixão crítica", a quem Paz define como "paixão vertiginosa, pois culmina na negação de si mesma" e como "uma espécie de autodestruição criadora ${ }^{210 "}$. O que distingue, portanto, esta modernidade, situada por nós a partir do século XIX, das outras modernidades artísticas, é sua apresentação do diferente como negação, como afirmação de um "depois" diante do "antes". Entretanto, assombra-nos a associação entre as palavras "crítica" e "paixão", pois de uma esperamos o distanciamento, o olhar analítico, os movimentos de desconstrução e precisão, sem jamais apelar aos preconceitos, enquanto da paixão esperamos devoção, entrega, o que implica numa aproximação, sem o olhar ativo da análise, mas uma passividade diante de seu objeto. Como se conjugam as duas? Paz afirma que

\footnotetext{
“a união entre paixão e crítica enfatiza o caráter paradoxal de nosso culto ao moderno. Paixão crítica: amor imoderado, passional, pela crítica e seus mecanismos precisos de desconstrução, mas também crítica apaixonada por seu objeto, uma crítica apaixonada por aquilo mesmo que nega. Apaixonada por si mesma e sempre em guerra consigo mesma, ela não afirma nada
}

210 Ibidem. p. 17. 
permanente nem se baseia em nenhum princípio: a negação de todos os princípios $^{211 " \prime}$.

Este impulso pela negação, pela sobreposição do novo ao antigo, só poderia ser filho de uma época, segundo o autor, a da aceleração do tempo histórico.

Neste ponto, Paz inicia uma crítica à concepção de tempo histórico como linearidade, progressão e continuidade. Ainda que estejamos embargados desta forma de vivência histórica e temporal, Paz demonstra seu espanto diante da impossibilidade de atestarmos, de fato, se há uma aceleração temporal: “Não faltará quem se pergunte se a história está mesmo transcorrendo mais depressa que antes. Confesso que não sei

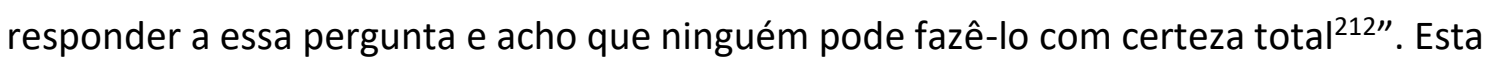
dificuldade é a mesma de não sabermos nomear o tempo em que vivemos. Entretanto, sobre o que se pode afirmar com clareza, nossa sensibilidade percebe que a variedade de eventos que se assomam nos últimos anos parece ser superior às que, historicamente, consideramos relevantes nos tempos mais antigos e na Idade média. Questão de perspectiva? Cremos que não, pois a modernidade torna a mudança seu ponto fixo, sua característica essencial. Daí derivam desta época tantas transformações, como as que se deram na técnica, nas artes, na política e na moral. O que Paz pretende mostrar em Os Filhos do Barro é que, no interior destas mudanças, mesmo aquelas que se deram mais radicalmente no interior dos movimentos de vanguarda, é possível vislumbrar um traço de continuidade: justamente o traço contínuo do que podemos chamar de sua "anti-história".

Embora paire sobre nós uma dúvida sobre a forma como concebemos o tempo graças à nossa dificuldade de vermos o próprio tempo que nos circunda e nos rege fato inerente a toda época -, no entanto, Paz afirma que é possível confirmar o seguinte:

${ }^{211}$ Ibidem. p. 18.

212 Ibidem. p. 19. 
transformações incessantes, uma coisa é inegável: nossa imagem de tempo mudou $^{213 \prime \prime}$.

Imagem de tempo é o termo utilizado por Paz para se referir à maneira como uma determinada sociedade percebe a temporalidade que a rege. Esta temporalidade aparece de forma imagética à nossa percepção, não necessariamente porque pensamos o tempo de uma forma espacializada ${ }^{214}$, mas, porque nossa intuição coletiva a constrói assim. O ser humano não é inventor do tempo, tal como foi inventor do relógio. Paz dirá que o homem é tempo. Neste sentido, compreender como a temporalidade se manifesta em imagens que são, muitas vezes, cíclicas, circulares, lineares, espirais, etc. é compreender como, dentro da infinidade da imaginação humana, nossa intuição pode apreender o tempo em imagens que, se não o descrevem, pelo menos the conferem sentido histórico, cultural e social.

Quais as consequências históricas de uma mudança de imagem de tempo? Para Octavio Paz, quando uma imagem de tempo muda, gradualmente muda também "a nossa relação com a tradição ${ }^{215 "}$. Atualmente, o autor afirma que vivemos um presente onde há uma confluência de múltiplas temporalidades: "aceleração e fusão: todos os

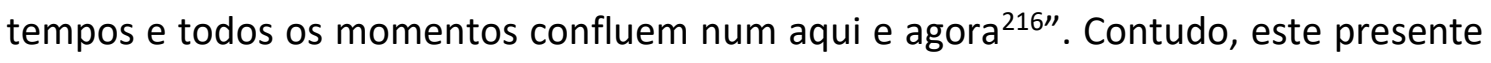
ainda é um não-lugar, cuja finalidade está posta fora. A função dele, na modernidade, é apenas a de oferecer o local da mudança e da transição, a qual jamais tem um fim em si próprio, pois sua finalidade é o futuro. Ora, se vivemos um momento de consonância e fusão de diversas temporalidades plurais, mas todas elas permanecem direcionadas a um polo único de atração, é porque sobre elas ainda existe uma relação hierárquica. No caso, é como se a visão de tempo linear, sucessiva e histórica fagocitasse as demais imagens de tempo em seu âmbito, num gesto de dominação. Acrescente-se que esta

\footnotetext{
213 Ibidem. p. 21.

${ }^{214}$ A análise de Paz sobre as formas orientais de compreender a temporalidade, como a budista, a do Tao, etc. mostram que nem todas as concepções passam pelo crivo do espaço. Muitas, pelo contrário, trazem no bojo um problema ontológico sem referência à realidade extensa. Algumas, inclusive, são caracterizadas pela negação do próprio tempo, enquanto realidade humana.

215 Ibidem.

216 Ibidem.
} 
relação é, ela também, uma relação política, como já expusemos acerca de $O$ Labirinto da Solidão. Ainda em Os Filhos do Barro, Paz afirma:

\footnotetext{
“não é a primeira vez que uma civilização impõe suas ideias e instituições a outros povos, mas é a primeira, em vez de postular um princípio atemporal, postula como ideal universal o tempo e suas mudanças. [...] O Ocidente se identifica com o tempo e não há outra modernidade senão a do Ocidente. Só restam bárbaros, infiéis, gentios, imundos; ou melhor, os novos pagãos e pulhas se encontram aos milhões, mas se chamam (nos chamamos) subdesenvolvidos... ${ }^{217 " \prime}$.
}

A ideia de subdesenvolvimento parte do pressuposto de que todas as nações, todas as culturas, devem almejar alcançar um patamar único, o que, evidentemente, é falso, pois não há como quantificar nem mensurar os fenômenos sociais através de um padrão universal. No mais, no que toca à evolução particular de cada uma destas sociedades, Paz é bem enfático: "a história desconhece a linha reta ${ }^{218 ", ~ o ~ q u e ~ c o l o c a ~ e m ~ q u e s t a ̃ o ~ a ~}$ própria ideia de evolução como progresso teleológico, sem desvios, dobras ou recortes que o elemento imponderável da marcha histórica produz.

Para Paz, o impacto de uma transformação em nossa imagem de tempo interfere em todas as áreas e esferas da ação e do saber. Para explicar tal relação, o autor retoma os arquétipos temporais das sociedades antigas ou dita "primitivas" que comungam de uma noção de temporalidade avessa à nossa - marcada pela aceleração e pela fugacidade. Tais culturas, como a cristã medieval, para quem o arquétipo perfeito era a eternidade cristã, sofrem a regência desta temporalidade à medida em que seu desígnio é o de anular os efeitos e as influências que as transformações da duração temporal e suas metamorfoses históricas inerentes possam vir a causar. Ou seja, trata-se uma maneira de conservar o que é da forma como está. Nesse sentido,

\footnotetext{
217 Ibidem. p. 31.

218 Ibidem. p. 32.
} 
"uma das funções do arquétipo temporal é oferecer uma solução transhistórica para essas contradições e assim preservar a sociedade da mudança e da morte. Por isso, cada ideia do tempo é uma metáfora feita não por um poeta, mas por um povo inteiro. Passagem da metáfora ao conceito: todas as grandes imagens coletivas de tempo se tornam matéria de especulação de teólogos e filósofos ${ }^{219 \prime \prime}$.

Passagem da metáfora (imagem) ao conceito: nossa relação distanciada com o tempo é, portanto, uma relação histórica, ainda que se pretenda, muitas vezes, anular os efeitos de transformação desta. Diante disso, perguntamos: quem nomeia o tempo? Certamente, não é a visão crítica da história, mas o povo e seus poderes de fabular, imaginar e intuir o que nos circunda. Daí decorre a ambiguidade de a modernidade ser, justamente, a união destes dois princípios, destas duas formas de compreensão do mundo: a analogia (imaginação transcendente, capacidade de estabelecer conexões íntimas entre as coisas) e a ironia (consciência história e consciência da mortalidade, filha do tempo linear acelerado da indústria).

Ora, podemos afirmar que o culto ao presente, esta forma de hedonismo em que se transformou toda consideração do agora, converteu o tempo numa "experiência" subalterna ao afirmar que o futuro, em sua supremacia, "é o íma do presente e a pedra de toque do passado, [na qual] o homem moderno se vê lançado ao futuro com a mesma

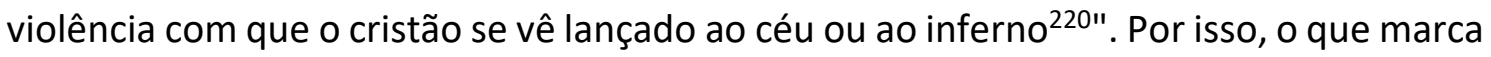
o nascimento da modernidade é a crítica à ideia de eternidade cristã, da mesma forma que a imagem de tempo cristão surgiu numa crítica à concepção cíclica, também afetada pela concepção moderna. Por isso, é correto afirmar que o que ocorre, inicialmente, é uma real "aceleração do tempo histórico", na medida em que os fatos vão ganhando peso. Dessa forma, o 'ontem' se torna uma carga pesada não por sua unidade temporal, mas por sua intensidade e importância factual. Isso é mais evidente se elencarmos fatos históricos, como os que nos representam as revoluções e guerras do século XIX e primeira metade do XX. O mesmo vale para nosso trato com as tradições: torná-las presentes não depende mais do local histórico em que elas se situam, nem de sua curta

\footnotetext{
219 Ibidem. p. 35.

220 Ibidem. p. 40.
} 
ou longa distância temporal, mas da valoração que nós lhe atribuímos, como, por exemplo: se elas afrontam diretamente ou rompem frontalmente com a nossa tradição atual, vigente, isto é, se gozam de algum estatuto "negativo" no contexto que pretendemos atingir.

Entretanto, se pensarmos a experiência do presente na sociedade pós-industrial e contemporânea, como sugere Frederic Jameson, teremos que, ao mesmo tempo em que o passado se torna espesso, somos assomados por uma "amnésia histórica". Acerca deste fenômeno em voga nas sociedades contemporâneas, Jameson diz:

\begin{abstract}
“acredito que a emergência da pós-modernidade está estreitamente relacionada à emergência desta nova fase do capitalismo avançado, multinacional e de consumo. Acredito também que seus traços formais expressam de muitas maneiras a lógica mais profunda do próprio sistema social. No entanto, vou limitar-me a indicar esta relação a propósito de um só de seus temas capitais: o desaparecimento do sentido da história (negrito nosso), o modo pelo qual o sistema social contemporâneo como um todo demonstra que começou, pouco a pouco, a perder a sua capacidade de preservar o próprio passado e começou a viver em um presente perpétuo, em uma perpétua mudança que apaga aquelas tradições que as formações sociais anteriores, de uma maneira ou de outra, tiveram de preservar. Basta mencionar a saturação informacional gerada pelos meios de comunicação: como Nixon e, ainda mais, Kennedy, são figuras de um passado agora distante. Sinto-me tentado a afirmar que a própria função dos meios de comunicação é de relegar ao passado tais experiências históricas recentes, isto o mais rapidamente possível. A função informativa dos meios seria, desse modo, a de ajudar a esquecer, a de servir de verdadeiro instrumento e agente de nossa amnésia histórica ${ }^{221 "}$.
\end{abstract}

O tempo presente, cuja fixidez e irrealidade compõem suas principais características, pelos motivos acima mencionados, será o tempo a ser confrontado por outra experiência do presente: a poética. A experiência do tempo fixo, do presente amnésico, ${ }^{221}$ JAMESON, Frederic. Pós-modernidade e sociedade de consumo. Trad. Vinícius Dantas. Novos Estudos
Cebrap, no12. Junho, 1985. p. 26 
ainda é uma experiência em que a aceleração do tempo permanece e, por conta dela, produz a amnésia histórica. A experiência poética, a experiência política da revolta e a da festa podem se dar no momento em que não estamos embotados de atenção dos reclames midiáticos, das propagandas que explodem como fogos diante de nossos olhos e do ramerrão de informações, fatos e opiniões que as mídias virtuais e digitais oferecem, graças à facilidade da comunicação atual e às formas que a tecnologia enveredou para se impor, cada vez mais, nas vidas intimas. Esta outra experiência será como o limiar do sonho e da razão, pois o domínio do sonho implica necessariamente uma desatividade, uma desaceleração do tempo, sua transmutação. O limiar é o que pode oferecer algo, talvez não a completude, do que pode ser dito, nomeado e talvez relatado. Este limiar não nos permite identificar se é real ou não, uma vez que se encontra numa zona de indeterminação: entre o sono e a vigília. O real, posto em dúvida - tornado enigma -, é mais necessário que o real que se impõe como hiper-realidade. Contudo, para que resista engima há que se resistir uma forma particular de imagem.

Ainda que possamos questionar o estatuto do real e da imagem que dele fazemos, a mediação de nossa compreensão epistemológica não depende apenas do conceito, uma vez que está permeada pelas imagens. Em O Arco e a Lira, Paz afirma que o sentido poético da imagem designa "toda forma verbal, frase ou conjunto de frases que o poeta diz e que juntas compõem um poema $222 "$. Assim como o ritmo, a imagem é matéria bruta da atividade poética, é aquilo que o poeta deve lapidar para construir um sentido no mundo, afinal, ela é "marca da condição humana ${ }^{223 " . ~ S e n t i d o ~ q u e ~ n a ̃ o ~ d e v e r a ́ ~}$ ser resumido à representação mimética do "impossível verossímil" aristotélico, pois a imagem não se restringe à finalidade de imitar, a fim de parecer, mas se atreve a recriar.

Para Paz, atribuir à arte e à poesia a tarefa de "representar" o mundo implica um distanciamento a ser desprezado pelo artista atual: este deve apresentar uma unidade (ou unidades) extraída da pluralidade diversa que é o real. Apresentar o que o mundo é, não suas possibilidades de ser, não um mimetismo de interpretações subalternas. $E$ quando falamos em "extrair", com isso não queremos dizer "abstrair", pois o próprio processo de abstração prevê o afastamento da imagem no interior de uma redução

\footnotetext{
222 PAZ, Octavio. O Arco e a Lira. Trad. Ari Roitman e Paulina Wacht. São Paulo: Cosac Naify, 2012. p. 105. ${ }^{223}$ Ibidem.
} 
lógica - às vezes, matemática e abstrusa, incapaz de expressar as nuances qualitativas de um ser - devido à necessidade de uma operação conceitual que seja capaz de expor, com clareza, as relações implícitas nas coisas, ignorando a sua complexidade e o "outro lado" de seu ser, aquele mais imediato aos sentidos e que contém uma relação interna mais dinâmica.

Na visão de Max Horkheimer, a configuração de conceitos não é apenas um processo redutor, escamoteador, se se relaciona à realidade levando em conta a sua realidade movente. Ele diz que

\footnotetext{
"contribui para o emprego correto de um conceito, em primeiro lugar, a reflexão sobre o processo no qual se configura a estrutura teórica que o compreende, e, depois, o movimento de pensamento que vai de cada parte desta estrutura até ele. $\mathrm{O}$ pensamento torna-se tanto mais progressista e verdadeiro quanto mais, nos seus conceitos e juízos, em suma, em todas as suas manifestações, ele se faz acompanhar da consciência das atividades materiais e teóricas da sociedade ${ }^{224 \prime \prime}$.
}

Em suma, o importante a se notar aqui é que a relação do conceito dialético não permanece a mesma com o objeto "de uma vez por todas", uma vez que cada "configuração teórica só possui efetivamente validade enquanto condiz com a realidade constantemente mutável e com as novas exigências originárias da situação do conhecimento $225 "$.

Entretanto, nem por isso, o processo de "recriação do mundo" se submete às regras do processo dialético. Paz afirma que nem todas as imagens são abrangidas por esta lógica, pois a chocam em seu interior. A 'lógica' da imagem, muitas vezes, não admite a abstração e é hostil à conceituação:

\footnotetext{
${ }^{224}$ HORKHEIMER, M. Sobre a metafísica do tempo de Bergson. Trad. Maurício G. Chiarello. São Paulo: Revista USP, no 6, 2000. p. 77.

225 Ibidem.
} 


\begin{abstract}
"no processo dialético pedras e penas desaparecem em favor de uma terceira realidade, que não é mais pedra nem pena, e sim outra coisa. Mas em algumas imagens - precisamente as mais elevadas - as pedras e as penas continuam sendo o que são: isto é aquilo e aquilo é aquilo; e, ao mesmo tempo, isto é aquilo: as pedras são penas sem deixar se ser pedras. $O$ pesado é leve. Não se dá a transmutação qualitativa que a lógica de Hegel pede, como não houve a redução quantitativa da ciência ${ }^{226 " \text { ". }}$
\end{abstract}

A função do poeta é colocar a matéria num estado de liberdade. Se a ciência a aprisiona e a razão a condena à imoblidade da definição conceitual, o poeta deve ser cortês a esta: assim como dela se serve, deve permitir que ela restabeleça seu local primário, seu sentido profundo. Paz pontua que as palavras, quando convertidas em imagens, "[transcendem] a linguagem enquanto sistema dado de significações históricas. 0 poema, sem deixar de ser palavra e história, transcende a história227". Matéria livre é matéria convertida em imagem, colocada para além da linguagem (mesmo que através dela) e da nossa capacidade de compreender o mundo pelos seus mecanismos. E a matéria para o artista é o que deve ser talhado, transformado e devolvido à sua natureza íntima e fundamental, estado primitivo.

Por isso, é necessário pensar a natureza destas imagens para além do conceito, pois importa mais a sua ambiguidade que sua clareza. Sobre isto, em regime de "antecipação dramática", Baudrillard pensa justamente a pauperização do universo imagético - anteriormente insuflado de enigmas, mas agora desprovido de origem incapaz de fabular (ou mesmo narrar), subordinado à ordem dos simulacros:

\footnotetext{
“os acontecimentos (événements) [que] já não teriam mais sentido, [...] não porque seriam insignificantes em si próprios, mas porque teriam sido precedidos pelos modelos (ou simulacros), com os quais seu processo não faz mais do que coincidir $228 "$.
}

\footnotetext{
${ }^{226}$ PAZ, Octavio. O Arco e a Lira. Trad. Ari Roitman e Paulina Wacht. São Paulo: Cosac Naify, 2012. p. 106. 227 Ibidem. p. 31.

${ }^{228}$ BAUDRILLARD, Jean. Simulacro e Simulação. Trad. Maria João da Costa Pereira. 1ạ Ed. Lisboa: Relógio d’Água, 1991, p.76 apud FABBRINI, Ricardo Nascimento. “O que está acontecendo com as imagens?”, Campinas. Revista Filosofia e Educação. Vol. 8. №1. 2016, p.66.
} 
Neste sentido, cabe a nós pensarmos, como sugere Ricardo Fabbrini sobre este diagnóstico do filósofo francês, se "é possível, ainda, [à arte] produzir uma imagem que detenha algum enigma que indicie algum segredo, mistério ou recuo ${ }^{229 "}$, diante deste quadro de "morte do real". Uma imagem que reivindique seu local no mundo e se resguarde, em seu mistério, aberta ao desocultamento da fruição, e que não seja meramente descodificável no consumo, pode ser compreendida enquanto "imagem de resistência". A afirmação desta imagem, possivelmente dada pela negativação, também pode se caracterizar pela capacidade constitutiva de fabular. Para Baudrillard, este tipo de imagem porta-se como "o instante fabuloso de deixar entrever que esse mundo real corre o risco de a todo o instante perder seu sentido e sua realidade ${ }^{230 \prime}$. É possível afirmar que um detalhe importante deste instante fabular é sua capacidade de extrair o fruidor da temporalidade da produção regida pela lógica do trabalho, em que toda a sociedade se encontra submetida. Neste sentido, acreditamos que o instante fabular é tão fundamental à arte quanto o "instante poético", no qual, se algo pode voltar à cena, este algo é o "referente" enquanto experiência de um mundo concreto. Para Paz, o centro desta referência seria, certamente, uma experiência sensível em que o corpo, obliterado e esquecido, encontraria seu espaço através da reminiscência da poesia. Neste sentido, a maior imagem de resistência não poderia ser senão o próprio corpo.

Se, por um lado, as imagens de tempos cíclico e sucessivo-finito nos condenavam à imobilidade, o tempo moderno nos condena à necessidade de nos movermos em direção ao nosso arquétipo, a agirmos e intervirmos na realidade que nos é posta, em exclusiva direção ao futuro, que tomou o lugar imaginário outrora ocupado pela eternidade. A relação desta imagem de tempo conosco pressupõe as normas imperativas que indicamos anteriormente, no que toca à hiperinflação das imagens bem como à aceleração do tempo e suas devidas consequências. Parece contrassenso falar em "arquétipo futuro", pois arché nos remete ao originário, elemento puro, primordial, àquilo que está fundamentado antes, mas, a forma como o futuro opera, na modernidade, é como uma pedra fundadora negativa: solapa o presente e reconfigura

\footnotetext{
229 Ibidem.

230 Ibidem. p 73.
} 
o passado, em vista da realização de seus projetos jamais alcançáveis: a utopia e o progresso. O que evidencia o fato de que o futuro não é menos impositivo que os outros arquétipos temporais das outras sociedades, de modo que se mostra tão ou mais imponente que estas, pois, como temporalidade, também se impõe às demais sociedades. Cabe ressaltar, portanto, que o futuro como íma da tríade temporal se consagra nas noções de "diferença, separação, heterogeneidade, pluralidade, novidade, evolução, desenvolvimento, revolução, história ${ }^{231 ", ~ e t c . ~ M a s, ~ s o b r e t u d o, ~ e ́ ~ n a s ~ i d e i a s ~ d e ~}$ Nação, Estado e Técnica que esta temporalidade encontra seus efeitos mais profundos, confluídas no que Paz classificou como "espírito laico".

A crítica de Octavio Paz sobre o "espírito laico" (pensando aqui, especialmente, no regime ditatorial e positivista de Porfírio Diaz) fica mais clara quando se lê esta avaliação mediante as medidas impositivas do ditador que retirara da população mexicana desde suas terras a seu refúgio espiritual. Para Georg Otte,

\footnotetext{
“a reforma, além de impor uma ideologia europeia que pouco tinha a ver com a realidade pré-industrial mexicana, aboliu os calpulli, as comunidades rurais que eram protegidas durante a época colonial. Viver nessas comunidades era, ao mesmo tempo, viver em comunhão com o passado pré-hispânico, ou seja, cultivar uma tradição. Se a Igreja Católica ainda permitia conservar, de alguma forma, as religiões autóctones, a mentalidade positivista do final do século XIX não deixou mais nenhuma brecha para que se mantivessem inatos os vínculos com o passado. Quando estourou a Revolução de 1910, o povo mexicano não tinha mais nada a perder, pois, para ele, tudo já estava perdido, principalmente a identidade cultural ${ }^{232 "}$.
}

A Revolução mexicana, uma das únicas que defendeu Paz em sua vida, pode ser interpretada como um gesto de revolta contra uma ideologia política imposta, mas, da mesma forma, pode ser vista como uma reação à sobrepujança de uma temporalidade que não pertencia à experiência e ao tipo de vida dos povos pré-hispânicos.

\footnotetext{
${ }^{231}$ PAZ, Octavio. O Arco e a Lira. Trad. Ari Roitman e Paulina Wacht. São Paulo: Cosac Naify, 2012. p. 28. 232 OTTE, George. Algumas afinidades entre Octavio Paz e Walter Benjamin In MACIEL, M. A Palavra inquieta. Belo Horizonte: Autêntica: Memorial da América Latina. 1999, p. 197.
} 
Em comparação à Revolução Mexicana, em O Arco e a Lira, Paz discute uma das características da revolução moderna, que se trata da incapacidade de consagrar os princípios pelos quais sua ideia se funda. Mais do que isto, Octavio Paz estabelece uma dicotomia entre as ideias de revolução e revolta. Segundo Horácio Costa,

\begin{abstract}
"contra esta concepção linear e limitante, a qual caracterizam os valores de continuidade e de auto-reprodução, bem como ilusão e regularidade, Octavio Paz identifica uma mudança no padrão temporal do Ocidente, que implica na superação da noção finalista de revolução e sua substituição por aquela mais dúctil e aberta de revolta. “(...) la historia moderna ha cambiado de orientación y (...) asistimos a una verdadera revuelta de los tiempos", postula em Corriente Alterna. Os tempos se rebelam frente ao jugo do futuro; o resultado desta crise é a revalorização da noção de "revolta social", vista como lugar por excelência de afirmação da pluralidade de agentes e de tempos sócio-históricos ${ }^{233 "}$.
\end{abstract}

Diante da afirmação do futuro utópico ou progressivo e das suas promessas infrutíferas e áridas, o poeta deverá oferecer o que resta a esta realidade escamoteada por projetos colonizados: a memória.

Diante deste diagnóstico acerca da modernidade, somado aos fracassos da ciência e da humanidade em seus projetos arquetípicos de futuro, o autor afirma que a sucessão de sacrifícios vistos no século XX culminou num "vazio" de consciência":

\footnotetext{
"espírito laico ou neutralidade. Pois bem, "onde morrem os deuses, nascem os fantasmas". Os nossos fantasmas são abstratos e implacáveis. A pátria deixa de ser uma comunidade, uma terra, algo concreto e evidente, e se converte numa ideia pela qual todos os valores humanos se sacrificam: a nação. O antigo senhor - tirano ou clemente, mas que sempre se pode assassinar - é substituído pelo Estado, imortal como uma ideia, eficaz como uma máquina, impessoal como ambas e contra o qual não adiantam as súplicas nem a adaga porque nada se apieda dele nem o mata. Ao mesmo tempo o culto à técnica conquista as
}

${ }^{233}$ COSTA, Horácio. "Poíesis" e política: o modelo intelectual de Octavio Paz. São Paulo: Revista USP, 1991. p.90 
almas e substitui as antigas crenças mágicas. [...] O homem moderno se serve da técnica como o seu antepassado das fórmulas mágicas, sem que esta, aliás, Ihe abra porta alguma ${ }^{234 \prime}$.

Consequência das raízes do iluminismo ou dos princípios do esclarecimento, o espírito de neutralidade que vem sendo, recentemente, questionado inclusive no meio das ciências em que costumava ser unanimidade, é a conjunção de três princípios que se creem em desenvolvimento progressivo: técnica, estado e nação. Resta saber qual é o óleo que lubrifica estas engrenagens e permite que elas nos orientem, tal qual um trem, rumo a um destino único.

Por mais que Paz contraponha, muitas vezes, o espírito laico aos impulsos humanos que pensavam o universo através da magia, o autor não deixa de reconhecer que esta segunda é, também, uma forma de dominação e exercício do poder. Em $O$ Arco e a Lira, ele diz:

\footnotetext{
"as receitas do poder mágico contêm fatalmente a tirania e a dominação dos homens. Muitas vezes se assinalaram as semelhanças entre magia e técnica, e alguns pensam que a primeira é a origem remota da segunda. Seja qual for a validade dessa hipótese, é evidente que o traço característico da técnica moderna - tal como o da antiga magia - é o culto ao poder. [...] Sua rebelião é estéril porque a magia - isto é: busca do poder pelo poder - acaba aniquilando a si mesma. Não é outro o drama da sociedade moderna ${ }^{235 "}$
}

Sobre esta questão, Adorno e Horkheimer dirão, na Dialética do Esclarecimento, que o mito se converte na própria ciência, mantendo o elemento comum de busca pela dominação:

\footnotetext{
${ }^{234}$ PAZ, Octavio. O Arco e a Lira. Trad. Ari Roitman e Paulina Wacht. São Paulo: Cosac Naify, 2012. p. 227.

235 Ibidem. p. 61
} 


\begin{abstract}
"no estágio mágico, sonho e imagem não eram tidos como meros sinais da coisa, mas como ligados a esta por semelhança ou pelo nome. A relação não é a da intenção, mas do parentesco. Como a ciência, a magia visa fins, mas ela os persegue pela mimese, não pelo distanciamento progressivo em relação ao objeto. Ela não se baseia de modo algum na "onipotência dos pensamentos", que o primitivo se atribuiria, segundo se diz, assim como o neurótico. Não pode haver uma "superestimação dos processos psíquicos por oposição à realidade", quando o pensamento e a realidade não estão radicalmente separados. A "confiança inabalável na possibilidade de dominar o mundo", que Freud anacronicamente atribui à magia, só vem corresponder a uma dominação realista do mundo graças a uma ciência mais astuciosa que a magia ${ }^{236 \prime}$.
\end{abstract}

Este é o processo de quando o mito se converte em ciência. Contudo, cabe questionar o que acontece quando esta se converte, por sua vez, em mito. Não devemos nos esquecer que para Paz, se a operação poética guarda similaridades com a magia graças a seu procedimento analógico, por outro lado, o poeta moderno também é filho da idade crítica da modernidade que, lapidada na ironia, possibilita que, através de seus poderes de negação, esta venha a negar a si mesma. Por isso, o poeta, ao contrário do mago, será crítico da principal crença da modernidade, a qual exporemos abaixo.

Esta crença mítica é a aposta na capacidade de a nação, a técnica, o Estado e as ciências, em geral, assumirem um desenvolvimento evolutivo. O seu nome é Progresso. Este, enquanto ideologia, veio substituir nosso arquétipo de perfeição, a eternidade. Em Os Filhos do Barro, Paz diz que o cristianismo

\footnotetext{
"ao romper os ciclos e introduzir a ideia de um tempo finito e irreversível, [...] acentuou a heterogeneidade do tempo; quero dizer: evidenciou essa propriedade que o faz romper consigo mesmo, dividir-se e separar-se, ser outro sempre diferente. A queda de Adão significa a ruptura do presente eterno paradisíaco: o começo da sucessão é o começo da cisão ${ }^{237 ” .}$.
}

\footnotetext{
236 ADORNO, Theodor; HORKHEIMER, Max. A dialética do esclarecimento. Trad. Guido Antonio de Almeida. Rio de Janeiro. Zahar. 2006, p. 22.

237 PAZ, Octavio. Os filhos do barro. Trad. Ari Roitman e Paulina Wacth. São Paulo: Cosac Naify, 2013. p.26.
} 
A associação da imagem histórica à figura bíblica da queda aponta que o cristianismo deu à sucessão um caráter de irreversibilidade. As antigas cosmologias pressupunham o "eterno-retorno", por isso extraíam seus ideais de perfeição da figura incorruptível do círculo. Uma das passagens que Paz elenca para ilustrar como a poesia soube encarnar bem essa imagem de tempo cindida é a referência a Dante. Após o juízo final, haveria o reencontro de cada coisa consigo mesma. Este reencontro refere-se a um desvelar hiperbólico de cada essência, onde cada coisa seria mais exatamente o que já é, à maneira do que já foi no tempo anterior à Queda, o tempo do Criador, como fica evidente na seguinte passagem do Canto VI do Inferno da Divina Comédia:

\author{
E eu perguntei: "Meu Mestre, esse tormento \\ Crescerá ele após a grã sentença, \\ Ou será igual, ou terá lenimento?" \\ E ele: "Volta à tua velha conhecença \\ $\mathrm{Na}$ qual se ensina que o ser mais perfeito \\ Mais sente o bem e seja a ofensa. \\ Embora todo este povo mal feito \\ Não possa à perfeição nunca ir chegando \\ Pra lá, mais que pra cá, será seu eito ${ }^{238 " .}$.
}

Nesse sentido, o sofrimento do pecador no inferno será mais perfeitamente sofrimento e o graça do agraciado no céu será mais perfeitamente jubilo, por uma simples razão: estarão eternamente presentes no além-tempo divino, perfeito, das essências desveladas, onde o presente não transcorre e as criaturas de Deus não se corrompem. No, entanto, tendo em vista que a eternidade viria a consumir tudo, para onde aponta essa necessidade cristã de estabilidade e inalterabilidade das coisas?

Ora, o principal ponto de convergência entre a imagem de tempo cíclica e a cristã, segundo Octavio Paz, é que "são tentativas de anular ou, ao menos, minimizar as

\footnotetext{
${ }^{238}$ ALIGHIERI, Dante. A divina comédia - Inferno. Trad. Italo Eugênio Mauro. São Paulo: Editora 34. 2007. p.58.
} 
mudanças $239 "$, que na realidade são vistos como nefastas e imperfeitas, ao contrário da imagem que se tem deles na modernidade. Por conta disso, a mobilidade do cristão frente ao futuro é tão ou mais estável e fixa quanto o ímpeto à mudança e transformação do antigo. A volta de Cristo apaziguava qualquer impulso de se opor à ordem geral. Restava, pois, uma postura de espera e temor em relação ao andar marchante do tempo e à degradação humana. Portanto, é correto afirmar que a inovação e o novo não gozavam de grande credibilidade, exceto nos registros em que as modificações não implicavam uma grande ruptura nas artes.

Com o surgimento da modernidade, esta ideia sofre crítica e, associada ao espírito laico, perde seu potencial de acalentar os impulsos humanos de transformação. Verificamos uma evidente modificação valorativa das palavras: contingência, história, revolução, evolução, desenvolvimento e daquelas que já apresentamos como negativamente taxadas pelos outros períodos históricos. Ora, trata-se de uma consequência fundamental: a nossa tradicional intenção por minimizar os efeitos do tempo perdeu toda sua razão de ser, pois esses efeitos nada mais são que mudanças e essas mudanças, pela primeira vez, tornam-se fundamento de uma imagem de tempo e de uma sociedade. Assim, alterada nossa imagem de tempo, por consequência, nosso conceito de perfeição sofre uma brutal inversão. A afinidade estética e moral que tal conceito compartilhava com o estável, o fixo, o persistente e o eterno perde seu valor em detrimento da nova relação que estabelece com o instável, o móvel, o transitório o temporalmente finito e, principalmente, o momentâneo. É esse mesmo ambiente que dá aval a todos os conceitos e permite que todos eles funcionem integralmente como imperativos da nossa sociedade.

Diante desta tradição que se quis ruptura, bem como de todos estes imperativos apresentados acima, a festa, em conjunção com a revolta, se colocará como paradigma da juventude. Em Conjunções e Disjunções, Paz dirá que figura no presente 
religiões, mas a incandescência do instante: consumação e abolição das datas. Qual é a porta de entrada para esse presente? André Breton falou uma vez da possibilidade de inserir na vida moderna um sagrado extra-religioso, composto pelo triangulo: amor, poesia e rebelião. Esse sagrado não pode emergir senão do fundo de uma experiência coletiva. A sociedade deve manifestá-lo, encarnálo, vive-lo e, assim, viver-se, consumar-se. A revolta como caminho para a iluminação. Aqui e agora: salto para a outra margem ${ }^{240 "}$.

Neste contexto, o salto a que se refere Octavio Paz deve ser compreendido como um salto mortal, expressão que o autor adota "à espanhola". Para o crítico francês Paul Henri Giraud, ao falar deste salto, Paz alude a um "êxtase, na acepção própria do termo, uma deslocação para fora de si mesmo e do mundo sensível de modo a atingir aquilo a que o budismo chama "outra margem ${ }^{241 "}$ ". Para dar prosseguimento a esta explicação, Giraud faz menção ao termo utilizado por Paz em Conjunções e Disjunções: "Mahâprajñâpâramitâ" que, em sânscrito, significa, basicamente: "grande-sabedoria-

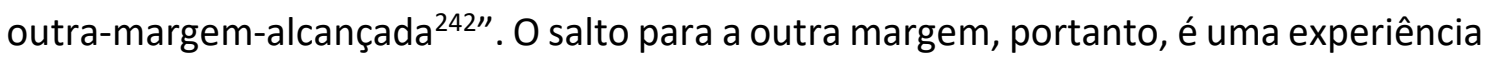
de perfeição, onde esta significa uma conjunção dos opostos ou, simplesmente, a coincidência dos contrários. A este princípio lógico oriental, suplantado no Ocidente, onde vigorou longamente o princípio da não-contradição aristotélico, Mircea Eliade denomina coincidentia oppositorum, ao pensar a estrutura das religiões, nas quais "a própria estrutura da divindade, uma estrutura que se situa além dos atributos e que reúne todos os contrários ${ }^{243 "}$. Este princípio, a nosso ver, está presente no interior do método analógico paziano e pode ser reconhecido na eleição de diversas figuras-chave de seu pensamento, como Lévi-Strauss, do qual trataremos adiante. Contudo, é importante compreender que parte do sentido residente no princípio da outridade compartilha dessa divindade "radical", onde devemos compreender por divino aquilo que é "absolutamente outra coisa ${ }^{244 " . ~}$

\footnotetext{
240 PAZ, Octavio. Conjunções e Disjunções. Trad. Lucia Teixeira Wisnik. São Paulo: Perspectiva, 1979. p. 130.

241 GIRAUD, Paul Henri. Octavio Paz: caminho para a transparência. Trad. António Teixeira. Lisboa: Instituto Piaget, 2002. p. 85.

242 Ibidem.

${ }^{243}$ ELIADE, Mircea. Traité d'histoire des religions. p. 351 apud Ibidem, 2002. p. 86.

244 Ibidem.
} 
Por esta razão, a própria experiência da Festa guarda um parentesco com a religiosidade, uma vez que afirma uma realidade radicalmente outra. Para Eduardo Jardim, em seu diálogo ficcional $A$ duas vozes, em que podemos imaginar um hipotético encontro entre a filósofa Hannah Arendt e o poeta Octavio Paz, é certo que, pensando com o poeta, que encarna uma das vozes deste tête-à-tête,

\footnotetext{
"a vivência do sagrado e as ocasiões de festa também escapam ao tempo sucessivo e promovem um salto para o outro lado. Para o outro lado? Seria correto dizer que elas motivam a conversão ou a transfiguração do fluir temporal ${ }^{245 \prime \prime}$.
}

É por esta razão que as individualidades são emaranhadas umas nas outras e, muitas vezes, as próprias identidades dissolvidas, bem como todo código moral. Ainda que, muitas vezes, isso se dê de forma paródica ou sarcástica, as fantasias, as rupturas de códigos normativos de indumentária, formas de ação e mesmo a suspensão de certos tabus atendem não apenas à demanda por liberdade que é restrita boa parte do ano, mas também a uma necessidade de uma vivência que não é e, por razão desta suspensão da ordem, não pode ser ordinária e subordinada ao ritmo fabril da jornada de trabalho. Daí sua comunhão com o sonho e o aspecto lúdico da existência. Por isso, para Paz, a própria Revolta de 1968 se dará como uma

\footnotetext{
"nostalgia da festa. Mas a Festa é uma manifestação do tempo cíclico do mito, é um presente que regressa, enquanto que nós vivemos no tempo linear e profano do progresso e da história. Talvez a revolta juvenil seja uma festa vazia, o chamamento, a invocação de um acontecimento sempre futuro e que jamais se fará presente - jamais será246".
}

245 JARDIM, Eduardo. A duas vozes: Hannah Arendt e Octavio Paz. Rio de Janeiro: Civilização Brasileira, 2007. p. 76.

246 PAZ, Octavio. Ibidem. 
A partir desta colocação, poderíamos nos questionar com Paz: teria sido a experiência de Maio de 1968 uma atitude transformadora ou uma ilusão? O mexicano deixa esta pergunta em suspenso, pois volta sua atenção para o que a experiência da juventude pareceu reivindicar no seu âmago: uma nova experiência do tempo comum no agora.

Para Franco Berardi, o turning point pode ser identificado no ano de 1977, quando os jovens ingleses da banda "anarquista" Sex Pistols anunciavam, em Londres, dos seus microfones o epíteto "No future", indiciando o sentimento do niilismo que já predominava no esgarçamento das utopias. João Brandão, personagem da crônica de Carlos Drummond de Andrade, já refletia que "se tudo está errado por aí [...], uma postura punk descrente dos métodos e processos consagrados para nos salvar do abismo, tem razão de ser ${ }^{247 " \prime}$ porque esta razão já denunciava a falibilidade dos ideais que se projetavam no futuro, daí a raiz de sua negação. Quando Paz se refere a utopias, ele pensa, necessariamente, no comunismo, sobretudo a experiência soviética, cuja crise ainda não se acentuara nestes anos, mas já tendo passado a limpo, através dos processos de Moscou, as denúncias de Nikita Kruschev acerca dos crimes de Joseph Stálin. Octavio Paz foi extremamente sensível a estas questões e, tendo em vista o assassinato de Leon Trótsky no México, não pôde deixar de romper com boa parte da intelectualidade socialista ou de esquerda mexicana e latino-americana, incluindo-se aí um de seus mentores, Pablo Neruda, apesar de ter se mantido seu interlocutor durante toda a vida. Por conta destas tensões, 1968 foi um ano irônico e Paz soube reconhecelo, valorizando seu aspecto bem-humorado. Berardi afirma:

\footnotetext{
“1968 não soube decidir-se entre uma versão dogmática da ironia, que culminou muitas vezes no terror, e uma versão irônica, que soubesse transformar-se em projeto. Em nome da sociedade ideal, constituíram-se, no século XX, estados autoritários e justificou-se o exercício do terror. [...] Quando o projeto conhece sua imperfeição, a utopia se faz irônica. A ironia é a suspensão do sentido de um enunciado, suspensão da relação entre significante e significado. Irônico é quem compreende que as palavras se concatenam em um plano que não é coextensivo do plano do real. A ironia
}

${ }^{247}$ ANDRADE, Carlos Drummond. João Brandão adere ao punk. Rio de Janeiro: Jornal do Brasil, 1983. 
aponta [...] um outro sentido possível, ou talvez uma infinidade de outros sentidos possíveis ${ }^{248 \prime \prime}$.

A resposta niilista aponta, muitas vezes, uma saída pelo riso e pelo humor. É preciso compreender que a ironia esteve imersa em boa parte das criações artísticas deste período, como indicaremos, logo mais, numa esteira que vem desde Marcel Duchamp. O "programa dadaísta", que consistia, basicamente, na abolição da separação interposta entre arte e vida, como fica explícito no grito de Tristan Tzara ${ }^{249}$, consiste em, basicamente, "exibir um signo para negar-lhe o significado ou para colocar em suspensão o significado que lhe atribuímos; exibir o caráter artístico daquilo que é banal,

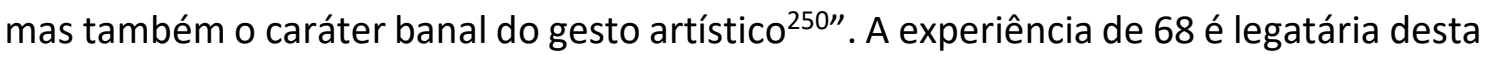
postura irônica e, sem ela, não teria a possibilidade de interligar, em sua gestualidade, as esferas da Revolta e da Festa. Por esta razão, ao interpretar o caráter do slogan do Movimento estudantil de 1968, "Sejam realistas, exijam o impossível", inscrito nos muros de Paris, Franco Berardi dirá que "nessa expressão do Maio de 1968 está implícito todo o trabalho de desconstrução da relação entre a Realidade e a Razão que o dadaísmo e o surrealismo haviam desenvolvido nos anos anteriores ${ }^{251 "}$. Relação que é pressuposto básico do desenvolvimento conceitual dialético no pensamento hegelianomarxista. Em suma, a juventude, enquanto movimento, opta pela primazia da imagem e a festa se torna sua encarnação primeira.

A respeito do caráter contemporâneo da festa, o filósofo sul-coreano Byung-Chul Han, em A Sociedade do cansaço, diz que

\footnotetext{
"na festa, o tempo como sequencial de momentos passageiros e fugidios é suspenso. Adentramos na celebração da festa como adentramos num espaço onde nos demoramos. O adentrar numa celebração se contrapõe ao
}

\footnotetext{
${ }^{248}$ BERARDI, Franco. Depois do futuro. Trad. Regina Silva. São Paulo: Ubu Editora, 2019. p. 23.

249 Ibidem. p. 75.

$250 \mathrm{Ibidem}$.

251 Ibidem. p. 79.
} 
transcorrer. No adentrar a celebração não há nada que transcorre e passa. 0 tempo de festa num certo sentido não passa ${ }^{252 "}$.

Ao reconhecer o seu caráter disruptivo em relação às nossas experiências tempo, Han alude à necessidade de pensar até que ponto a própria festa não foi incorporada ao ritmo de trabalho impositivo na sociedade contemporânea. Quando a festa modula os aspectos da sociedade de consumo, ela perde todo o seu caráter arquetípico, isto é, a sua relação com o culto e seu aspecto celebrativo. Muitas das festas contemporâneas oferecem-se apenas na sua acepção utilitária, como o uso corriqueiro do entorpecente, dando continuidade à jornada diária e cotidiano do labor, obliterando seu aspecto ritual. Quando o tempo do trabalho se universaliza e corrompe a própria realização da festa, impondo seus ritmos e, sobretudo, suprimindo a sua abertura à outridade, confinando as pessoas em clubes cada vez mais individuais e gentrificados, é como se a própria festa e as horas em que nela estamos se tornassem coextensivas às nossas relações de trabalho, como o mero entretenimento.

Em suma, para o sul-coreano, não é possível a experiência da festa sem que esta implique a sua transmutação do tempo:

\footnotetext{
“a mera desaceleração não produz um tempo de celebração. O tempo de celebração é um tempo que não pode ser acelerado nem desacelerado. 0 assim chamado aceleracionismo, muito badalado atualmente, não percebe que na crise em que atravessamos atualmente não pode ser alcançado nem pelo processo de desaceleração nem pela aceleração. Precisamos de uma nova forma de vida, uma nova narrativa, donde possa surgir uma nova época, um novo tempo vital, uma forma de vida que nos resgate da estagnação espasmódica ${ }^{253 \prime \prime}$.
}

Quando Octavio Paz caracteriza a festa em O Labirinto da solidão, o autor deixa claro que a festa é uma conjunção dos contrários. A própria experiência da festa possibilita

\footnotetext{
252 HAN, Byung-Chul. Sociedade do cansaço. Trad. Enio Paulo Giachini. Petrópolis: Vozes, 2017. p. 110. 253 Ibidem. p. 112.
} 
esta nova vivência, se assumirmos que ela é uma complementaridade dos opostos, uma coabitação total, "amálgama primitivo". Para celebrar a vida, os mexicanos cultuam a deusa Morte; para comemorar o começo do ano e seu renascimento, celebra-se seu fim; "a morte provoca o renascer; o vômito, o apetite; a orgia, estéril em si mesma, a fecundidade das mães ou da terra ${ }^{254 "}$. Em resumo, a festa pode ser compreendida como uma afirmação do signo corpo, mas que depende, assim como todo par, do signo nãocorpo. Se um dos termos da disjunção se torna absoluto, o que visualizamos é o completo aniquilamento do termo restante.

Ao analisar e comparar como esta relação entre ambos os signos se deu no Ocidente e no Oriente, Paz considera que enquanto tivemos, no Ocidente, uma predominância do signo não-corpo, visível nas nossas religiões (judaísmo, cristianismo, islamismo) bem como nas suas vertentes mais ascéticas e contemporâneas - como o protestantismo -, o Oriente, graças, sobretudo, às tradições hindu e budista, vinculadas ao tantrismo, resguardaram o signo corpo. Em Conjunções e Disjunções, Octavio Paz diz:

\footnotetext{
"na Índia e na China o modo de relação entre os signos corpo e não-corpo foi a conjunção. No Ocidente, a disjunção. Em sua última fase, o cristianismo exagera a separação: condenação do corpo e da natureza na ética protestante. [...] Divórcio entre o céu e a terra: a virtude consiste no sacrifício da natureza para merecer o céu. Em sua última fase, o cristianismo engendra a sociedade areligiosa moderna e desloca a relação vertical entre os termos para um plano horizontal: o céu se faz história, futuro, progresso; e a natureza e o corpo, sem que deixem de ser inimigos, deixam de ser objetos de negação para se converter em sujeitos de conversão ${ }^{255 ”}$.
}

Paz reconhece que esta cisão dos signos corpo e não-corpo no Ocidente foi demarcada pelo desenvolvimento do capitalismo, segundo a análise weberiana do papel que o protestantismo possuiu em seu desenvolvimento ético. Entretanto, apesar de opostos,

\footnotetext{
${ }^{254}$ PAZ, Octavio. O Labirinto da Solidão. Trad. Ari Roitman, Paulina Wacht. São Paulo: Cosac Naify, 2014. p. 53.

${ }^{255}$ PAZ, Octavio. Conjunções e Disjunções. Trad. Lucia Teixeira Wisnik. São Paulo: Perspectiva, 1979. p. 104.
} 
o budismo e o cristianismo são caminhos divergentes que se cruzam. Na Índia pode-se estipular uma forma de racionalidade que realiza uma ruptura direta entre o que chamamos fenômeno (ou realidade fenomenal) e o absoluto (aquilo que Kant chamará numeno ou coisa em si - realidade essencial - ou seu contrário, o Nirvana - a vacuidade, o Nada), tomado como dissolução do mundo no interior do signo corpo. Sua forma mais radical é o relativismo de Nagarjuna, para quem "a ponte entre a existência e a extinção deixa de ser uma ponte: a vacuidade é idêntica à realidade fenomenal e perceber sua identidade, realiza-la, é saltar para a outra margem, alcançar a "Perfeita Sabedoria256". Esta perfeita sabedoria é o princípio prajñaparamita. Por outro lado, no Ocidente grego, de onde deriva a arte românica, se "concebe o templo como um espaço que é o âmbito do sobrenatural ${ }^{257 " \prime}$ : espaço terrestre, preso à terra, onde operam os princípios lógicos da razão e possui seu sentido ditado pelo ritmo, local onde se deve manifestar a Presença. Para Octavio Paz, estes dois instantes do desenvolvimento budista e cristão são "os dois grandes momentos [destas religiões] e em ambos se alcança, já que não uma impossível harmonia entre os dois signos [corpo e não-corpo], um equilíbrio dinâmico: uma plenitude ${ }^{258 "}$ e um instante de encarnação. Porém, há nesta relação entre os dois signos os seus momentos de maior desequilíbrio, o budismo primitivo e o protestantismo, marcados pela austeridade e ausência de símbolos corpóreos, isto é, a desencarnação. Encarnar-se é o devir-carne, é a materialização da divindade do âmbito terreno, através de seus símbolos, templos, práticas e liturgias. As esculturas, as festividades, a ritualidade, inclusive, a maneira como se simbolizam ou se praticam os sacrifícios - que devem fazer menção à carne - são manifestações de religiões que mantém na encarnação o seu critério de Presença da divindade. Na religião católica, podemos pensar que o milagre da transubstanciação é uma forma que mantém este aspecto, ainda que no âmbito simbólico, porém para o qual há uma referência direta à carne, atualizado na modernidade pelo relato do milagre de corpus christi. Já na religião protestante, o contato com o divino se dá de uma maneira abstrata e austera: vedamse os santos, as imagens que são marcas do sincretismo e estabelecem uma relação indireta na simbologia da eucaristia, a consubstanciação. A própria forma com que se

\footnotetext{
256 Ibidem. p. 57.

257 Ibidem.

258 Ibidem.
} 
expurgam os demônios, nas chamadas neopentecostais, atende a um ritual que, por mais corpóreo que seja, não estabelece, necessariamente, uma encarnação da divindade, mas apenas uma desencarnação do profano em sua manifestação mística.

Quanto ao budismo primitivo, Paz afirma que este teve de utilizar o estilo artístico que tinha à mão, cujos relatos literários e arqueológicos apontam uma predominância da sobriedade e da economia dos símbolos. Em suma, num sentido, Paz afirma que

\footnotetext{
"não deve ter sido muito diferente das igrejas protestantes: a mesma sobriedade ou simplicidade; o mesmo horror pelas imagens realistas do Crucificado e do lluminado [Buda]; a mesma veneração pelos símbolos abstratos: a cruz, a roda, o livro e a árvore.... ${ }^{259 \prime}$.
}

É preciso se ter em mente que, para Octavio Paz, a religião não deve ser compreendida apenas do ponto de vista da sua capacidade de apresentar uma coesão que torne a comunidade mais orgânica, tampouco deve ser reduzida à sua função social, mas deve ser avaliada a partir da sua capacidade de estabelecer imagens que venham a encarnar o mundo, que estabeleçam a harmonia entre os signos corpo e não-corpo, à medida que não oprimam um em detrimento do outro de forma cabal. É isto que constitui o divino nas religiões e que a aproxima da poesia: imagens que encarnam uma presença, a Presença do Outro - daquilo que Paz chama a outridade, objeto principal de sua poesia, revelado no instante. Por isso, o autor afirmará que, neste caso, o protestantismo e o budismo primitivo são, ambas,

\footnotetext{
“duas religiões sem estilo artístico próprio: uma porque ainda não o havia criado, a outra porque havia desprezado o que the oferecia o catolicismo romano. Ora, por mais austera que seja, uma religião sem liturgia, símbolos, templos ou altares não é uma religião ${ }^{260 \prime \prime}$.
}

\footnotetext{
259 Ibidem. p. 59.

260 Ibidem.
} 
Para Paz, a coincidência existente entre o princípio do budismo e a fase mais avançada do catolicismo é marca de uma ilusão: entre elas não há nenhuma correlação necessária, tampouco o compartilhamento, no tempo e no espaço, destas afinidades estilísticas. Por isso, o autor afirma que "esta breve descrição do duplo movimento da arte budista indiana e da cristã medieval - um que vai da desencarnação à encarnação e outro da encarnação à desencarnação ${ }^{261 " ~ m o s t r a ~ q u e ~}$

\footnotetext{
"cada uma traça uma espiral sem saber que reproduz, em sentido inverso, a traçada pela outra, como se se tratasse de uma duplicação, embora mais perfeita e complexa, desse jogo de simetrias que Lévi-Strauss descobriu no sistema mitológico dos índios americanos. Não é difícil deduzir a conclusão de tudo isto: se essas religiões não se tocam na história, cruzam-se nestas páginas. E cruzam-se porque o espírito de todos os homens, em todos os tempos, é o teatro do diálogo entre o signo corpo e não-corpo". Este diálogo são os homens ${ }^{262 " \text {. }}$
}

A última fase do desenvolvimento do budismo é sua fase tântrica, onde o próprio ato corporal da cópula representaria uma fusão entre o sujeito e o objeto: o Samsara. Tratase de uma correspondência entre as práticas sexuais e o cosmo religioso, através de uma linguagem alegórica marcada, sobretudo, pela poeticidade plural das palavras, poeticidade que possibilita que estas venham a significar o seu contrário. A afirmação do signo corpo neste contexto religioso vem acompanhado de uma doutrina da significação mutável das palavras: “o pressuposto básico do tantrismo é a anulação dos contrários [...]: a mobilidade dos significados, o contínuo vaivém dos signos e de seus sentidos $^{263 "}$. Nesta doutrina, o corpo é desmembrado em signos vivos, pulsantes, que resguardam em seu interior a analogia estabelecida pelos sacerdotes, reafirmada nas práticas sexuais realizadas de forma ritual. Paz diz:

\footnotetext{
261 Ibidem.

262 Ibidem.

263 Ibidem. p. 66.
} 
“a carne é efetivamente concentração mental; a vulva é um lótus que é a vacuidade que é a sabedoria; o sêmen e a iluminação são um e o mesmo; a cópula é, como reafirma Mircea Eliade, samsara, "identité de jouissance": fusão do sujeito e do objeto, regresso ao uno ${ }^{264 "}$.

Ou seja, neste universo, em que a religião é encarnada, o corpo é mais do que afirmado, ele é texto: constelação de signos variáveis, intercambiáveis e mutáveis entre si, local por meio do qual a divindade se manifesta e, com ela, coincidem-se os contrários. 0 corpo no tantrismo é signo poético: sentido e ritual; totalidade e vacuidade. Em suma, trata-se de um texto que é composto por uma série de metáforas que, na concepção de Paz, possuem a mesma função - poética - que anima a escrita surrealista e a linguagem de James Joyce, enquanto manifestações universais do princípio analógico que rege o mundo. Pensamos, novamente, na "escrita como duplo do cosmos ${ }^{265 " . ~}$

É pressuposto, pois, que esta relação com o corpo seja, por sua vez, uma relação estabelecida com o tempo. Para Octavio Paz, o oriente possui, dentre as principais formas de lidar com o tempo, justamente, uma postura filosófica e religiosa, uma vez que há superação da espacialidade no que chamaríamos "âmbito numinoso 266". Esta superação somente se dá por intermédio do tempo cíclico, reafirmado em seu aspecto ritual e de repetição. Para Octavio Paz,

\footnotetext{
"o tantrismo é uma tentativa sobre-humana de realmente ultrapassar o bem e o mal. Nesta desmesura poderia lembrar Nietzsche. Mas o "niilismo" de Nietzsche é filosófico e poético, e não religioso. E além disso, é solitário: a gargalhada e a dança do super-homem sobre o abismo do eterno retorno. 0 centro, o coração do tantrismo, é algo que Nietzsche rechaça: o rito. E não obstante, o rito é o eterno retorno, não há regresso dos tempos sem rito, sem encarnação e manifestação da data sagrada. Sem rito não há regresso. Contradição de Nietzsche: o super-homem, o "niilista acabado" é um deus sem religião (rito) e sem retorno; a do tantrismo: um rito que jamais desemboca na
}

\footnotetext{
264 Ibidem.

265 Ibidem. p. 79.

266 Ibidem. P. 72.
} 
história, que é só retorno, repetição. De novo: o que no Ocidente é ato e história, na Índia é rito e símbolo. À ideia de "transformar o mundo", a Índia responde (respondeu) com outra não menos impressionante: dissipá-lo, tornalo metáfora ${ }^{267 " \prime .}$

A metaforização do mundo ocorre graças à linguagem em estado de radicalidade, condição que a aproxima da poesia. Se, para Nietzsche, a própria ideia de verdade - em seu sentido extra-moral - é, por sua vez, a metáfora de uma metáfora, o resultado final da genealogia de todos os valores será a crítica axiológica do sistema que fez soterrar a vontade de potência e nisso sua crítica atinge diretamente a religião, inclusive por seu caráter coletivo (o que classificará como espírito de rebanho). O eterno-retorno defendido pelo filósofo importa mais pela sua acepção norteadora das ações humanas e da afirmação de uma vida onde impera a eterna vivacidade, despertando no ser humano seu sentido trágico, o Amor Fati, diante do destino que se avizinha à frente, enquanto no Tantrismo, Paz nos explica que o eterno-retorno é uma visão cosmológica, onde o tempo se repete tal e qual e os fatos se passam tal e qual: aqui, a metáfora é menos o resultado de uma postura moral diante dos conflitos humanos, dos regimes de verdade emplacados no discurso, do confronto entre nossas vontades e nossas afirmações psicológicas, axiológicas e políticas. O eterno-retorno opera como o sentido imanente à realidade fenomenal de um mundo que funciona, na linguagem, como o duplo de um universo onde Nada e Tudo coincidem numa mesma palavra: Prajñaparamita. Não que esta postura do tantrismo implique numa tomada de ações diferente das da ética pós-niilista proposta pelo filósofo alemão, pois ao jogar a vontade no centro da filosofia, Nietzsche devolve ao signo corpo um estatuto de valor anteriormente ofuscado (se não obliterado) pela metafísica ocidental. Contudo, a ruptura com o caráter coletivo, a postura crítica do "übermensch" isolado, como Zaratustra - pois à frente de seu tempo -, exclui o rito, exclui a celebração em comunidade, apesar de não excluir a poesia. Entretanto, o filósofo pensa com o martelo, em vista da destruição de toda uma arquitetura de ideias que tornou este mundo - o

267 Ibidem. 
nosso - submisso a um além-vida, incapaz de encarnar no instante presente a verdadeira vivacidade.

Num sentido similar, podemos pensar que Octavio Paz veicula as ideias e princípios imagéticos do tantrismo num sentido crítico em relação ao ascetismo do cristianismo protestante, uma vez que a sua preocupação também é pela "eterna vivacidade", ou seja, nos termos de Paz, pelo instante poético. Este instante somente é capaz de possuir seu sentido se encarnado no presente, por isso o autor dirá que

\footnotetext{
"frente ao achatamento verbal do cristianismo protestante, inimigo de toda escritura secreta, a linguagem simbólica e hermética; frente ao vocabulário neutro e abstrato da moral, as palavras genitais e as cópulas fonéticas e semânticas; frente às preces, aos sermões e à economia da linguagem racional, os mantras e suas cascavéis. Uma linguagem que diferencia o ato da palavra e, dentro desta, o significante do significado; outra que apaga a distinção entre a palavra e o ato, reduz o signo a mero significante, multiplica e troca os significados, concebe a linguagem como um jogo idêntico ao do universo no qual o lado direito e o esquerdo, o feminino e o masculino, a plenitude e a vacuidade, são um e o mesmo - linguagem que tudo significa, e que, em suma, significa nada ${ }^{268 "}$.
}

Então, a metáfora no tantrismo estabelece uma analogia entre o funcionamento das relações eróticas como uma estética que, além disso, é parte de toda uma cosmologia sexual. A centralidade do prazer é compreendida como um engendramento da espiritualidade, uma vez que o corpo não é apartado da religião, mas the constitui como um pilar. Ora, uma vez que o corpo se apresenta como o princípio estético e erótico do mundo no Tantrismo, podemos dizer que é o universo simbólico do eterno-retorno que Ihe perpassa, significando-o como formas de revelar no tempo a "outra margem".

Por isso, a imagem cíclica se apresenta, para Paz, como uma imagem mais sábia que a linha cega do progresso:

268 Ibidem. p. 80. 
"o indiano nega o curso e o transcurso; todas as suas práticas e meditações tendem a abolir o discurso e sua recorrência: fazer parar a roda das transmigrações. O taoísta flui com o fluir do cosmos: ser imortal é percorrer o círculo e, ao mesmo tempo, ficar imóvel no centro. É um paradoxo que vale tanto quanto o paradoxo cristão ou o budista. Vale tanto quanto eles e é incomparavelmente mais sábio que a louca corrida do nosso progresso, esse cego e soberbo caminhar de um ponto desconhecido em direção a outro igualmente desconhecido ${ }^{269 \prime \prime}$.

O ritmo da mudança é ilusório. Na cosmologia hindu, cujas ramificações também abraçam o tantrismo, o universo é condenado a repetir-se, pois sua duração condiz com o período de duração de um sonho de Brahma, o deus cuja cabeça é habitada sempre pelo mesmo sonho, o qual retorna toda vez em que Brahma se põe a dormir, num ciclo infinito que torna a própria transmutação do tempo uma ilusão. Ao comparar, novamente, as cosmologias cristã e hindu, em Vislumbres da Índia, Octavio Paz afirma que

\footnotetext{
"a história do gênero humano começa com a expulsão do Éden e nossa queda na história. No caso do hinduísmo (e do budismo) a causa não é anterior, mas inerente ao próprio tempo. Para o cristianismo, o tempo é filho da falta original; por isso sua visão do tempo é negativa, ainda que não inteiramente: os homens, pelo sacrifício de Cristo, e graças ao exercício de sua liberdade, que é um dom de Deus, podem salvar-se. 0 tempo não é só condenação; é também uma prova. Para o hindu o tempo, em si mesmo, é mau. Melhor dizendo, por ser impermanente e mutável, é ilusório. É tempo, é maya: uma mentira em aparência prazenteira, mas que não é senão sofrimento, erro, e finalmente, morte que nos condena a renascer na horrível ficção de outra vida igualmente dolorosa e quimérica ${ }^{270 "}$.
}

\footnotetext{
269 Ibidem. p. 99.

270 PAZ, Octavio. Vislumbres da Índia: um diálogo com a condição humana. Trad. Olga Savary. São Paulo: mandarim, 1996. p. 163.
} 
Poderíamos ainda nos perguntar: qual o interesse de Paz nessas cosmologias? Ao alocá-las em perspectiva, podemos afirmar que Octavio Paz, em sua análise, defende que é preciso sustentar que, para além de oferecerem uma outra relação com o corpo, estas cosmologias apresentam uma outra relação com o tempo, pois oferecem imagens de tempo diferentes. Existem, no Oriente, três atitudes diante do tempo que poderíamos tomar como as mais significativas:

\footnotetext{
"o indiano nega o tempo natural do taoísta e o tempo histórico de Confúcio, sacrifica-os no altar da vacuidade ou da não-dualidade; Confúcio absorve o tempo natural e sua essência: o ch'i, para transformá-lo em tempo histórico: família, sociedade, Estado; o taoísta nega o tempo histórico e a cultura para seguir o ritmo do tempo natural271".
}

Nestes casos, a visão sobre o tempo não desemboca em nada parecido com a concepção ocidental moderna, segundo a qual a mudança é elevada à categoria de fundamento da sociedade. Quando Paz afirma que estas temporalidades, como a proferida pelo taoísmo, são mais sábias, o mexicano deixa claro que pretende resgatar estas visões cosmológicas para, através de uma perspectiva crítica, desnudá-lo em seu sentido moral e poético, uma vez que o tempo teleológico-linear esvazia o presente de sentido.

O fato de o tantrismo fazer permanecer o fundamento analógico, através do processo de metaforização do mundo em relação ao corpo, permite que ele negue não apenas o tempo histórico, mas o tempo natural, imanente ao cosmo. De forma que, nas três atitudes citadas anteriormente, temos os seguintes desenlaces:

\footnotetext{
“o tantrismo nega o tempo histórico e o natural. Assim, a conjunção entre os signos corpo e não-corpo equivale, apesar do exagerado materialismo de suas práticas, a uma descorporificação. O taoísmo nega o tempo histórico e moral: aspira a reintegrar-se no tempo cósmico e a ser uno com o ritmo cíclico do céu e da terra que, alternadamente, se abraçam e se separam. É outro caso de
}

${ }^{271}$ Id. Conjunções e Disjunções. Trad. Lucia Teixeira Wisnik. São Paulo: Perspectiva, 1979. p. 100. 
conjunção, embora menos extremada que a do tantrismo budista e hindu. Menos extremada e mais fecunda. [...] Na conjunção budista o signo não-corpo assume a forma lógica do princípio de identidade: nirvana é samsara; na taoísta o ceticismo e o humor dissolvem o não-corpo: é mais uma poética que uma metafísica, um sentimento de mundo mais que uma ideia ${ }^{272 " . ~}$

Entre as concepções hindu e a greco-romana, o mundo sublunar representa a imperfeição, a decadência causada pela incompletude do ser que, não obstante sua carência, aspira à plenitude que reside na essência do Ser. No entanto, o caminho a se percorrer até este mundo perfeito é diverso, mas em ambos os casos, estas concepções concebem o tempo como uma carência, uma mácula, onde lhe falta não apenas substância, mas verdade. Em Vislumbres da Índia, Paz diz que

\footnotetext{
"tudo o que muda adoece de irrealidade; o real é o que permanece: o ser absoluto (Brahman). O homem é impermanente como o cosmo, porém em seu fundo está o ser (atman), idêntico ao ser universal. Ambos estão para além do tempo, fora do acontecer. O Ser não pensa, nem sente, nem muda: é. Por seu lado, o budismo negou o ser e viu o ego como um conjunto de elementos insubstanciais que a meditação deve desagregar e depois dissolver. Hinduísmo e budismo são uma crítica radical do tempo ${ }^{273 "}$.
}

Mesmo cronológico, o sonho de Brahma é uma negação do tempo histórico, dividido por eras. Mais extremada ainda, é a vacuidade budista, de onde sequer podemos afirmar qualquer coisa. De toda forma, a Índia é um exemplo claro de como a relação entre temporalidade e sociedade se dá através de uma relação mútua: é o tempo quem petrifica a sociedade e a impede de mudar, enrijecendo, durantes vários anos, o regime de castas. Certo, quem faz o tempo, diria Paz, são os homens, capazes de transfigurá-lo e transformá-lo. Porém, a consciência indiana é uma consciência cuja predominância é a atitude religiosa. Por isso, a afirmação do tempo cíclico impediu a formação de um

\footnotetext{
272 Ibidem. p. 101.

273 PAZ, Octavio. Vislumbres da Índia: um diálogo com a condição humana. Trad. Olga Savary. São Paulo: mandarim, 1996. p. 166.
} 
pensamento histórico e imobilizou a sociedade: a temporalidade circular põe a todos no mesmo ritmo ${ }^{274}$. Diferentemente, o tempo fundado na modernidade também cria uma imobilidade: a da nossa compreensão acerca de sua direção, o futuro. Consagrado ao progresso, o nosso futuro é imponderável e tomamos cada vez mais consciência disto quanto mais aprofundamos a nossa consciência histórica acerca do passado dos seres humanos e do cosmo terrestre. Para expô-lo, Octavio Paz sugere que esta incompreensão causadora da imobilidade é similar à aporia de Zenão, filósofo présocrático pertencente à escola eleata. Neste paradoxo, Zenão argumenta que uma flecha lançada jamais atingiria o seu objetivo, pois na intermitência entre um ponto e outro de sua trajetória, teríamos um espaço divisível em uma infinitude de partes, o que impossibilitaria o seu movimento. De forma similar, para Paz, na modernidade, "disparado para diante, flecha em linha reta, nosso tempo não tem mais sentido que o de ser um perpétuo movimento, cada vez mais perto - cada vez mais longe - da futura perfeição ${ }^{275 ”}$. O nosso imobilismo é um esvaziamento que perpassa o corpo: o futuro progressivo rouba-lhe todo o sentido, uma vez que só o vivenciamos plenamente no presente. No fim, esta temporalidade se impôs ao oriente e, com ela, todo o arcabouço político e técnico que lhe acompanha veio, se não substituir, ao menos pluralizar as concepções de tempo milenares que vigoravam em países como Índia, Japão e China, transformando-os em potências econômicas, militares e tornando estas nações mais populosas do que já foram outrora. O saber da ciência demonstrou-se capaz de dominar o mundo através de seus meios: a técnica moderna, simplesmente, "era a velha magia, agora ao alcance de todo aquele que conhecesse a fórmula do encantamento ${ }^{276 \prime \prime}$. E assim como as palavras de encantamento ritualmente proferidas, as fórmulas da física, os cálculos da astronomia e a profusão de bens de consumo causou fascínio. Ao lado do dharma, a bomba. Feito uma ideologia, o tempo moderno consumiu tudo o que tocou, numa forma imperiosa, à medida em que o próprio sistema capitalista - um de seus fenômenos - ia absorvendo todo o universo simbólico, transformando os valores simbólicos em valores de troca. Para Paz, "a aparição do tempo moderno resultou em uma inversão dos valores tradicionais, tanto na Europa como na Ásia: ruptura do tempo

\footnotetext{
274 Ibidem. p. 167.

275 Ibidem. p. 169.

276 Ibidem.
} 
circular pagão, destruição do absoluto intemporal hindu, descrédito do passado chinês, fim da eternidade cristã ${ }^{277 \prime \prime}$. O progresso é convertido na fé cuja religião é o capitalismo ${ }^{278}$.

Nas últimas páginas de Vislumbres da Índia, Octavio Paz, num movimento recursivo em seu discurso, se situa novamente em seu texto: subitamente, voltou ao tempo. Após denunciar, como o faz em diversas obras, as mazelas da ideologia do Progresso e das utopias que embotaram o nosso século $\mathrm{XX}$, o poeta conclui:

\footnotetext{
"nossa ideia de tempo fendeu-se e suas milagrosas invenções nos queimam as mãos e a mente. Talvez o remédio esteja em colocar no centro da tríade temporal, entre o passado e o futuro, a que nunca chegaremos, o presente. A realidade concreta de cada dia. Creio que a reforma de nossa civilização deverá começar com uma reflexão sobre o tempo. É preciso fundar uma nova política enraizada no presente. [...] Estas páginas começaram com uma tentativa de responder à interrogação que a Índia me fez. Agora terminam com uma pergunta que nos engloba a todos: em que tempo vivemos ${ }^{279 "}$ ?
}

O problema está posto. A atitude do poeta, seja diante do tempo ou diante do mundo, apesar das similitudes - isto é, quando ambos se valem da palavra como instrumento criador, capaz de estabelecer pontes outrora impensáveis - é distinta da do sacerdote, do mago ou do místico. Se, por um lado, muitas vezes, defronte aos oximoros da razão ou dos mistérios da fé, tanto o crítico como o místico escolhem se calar, ao poeta a opção de verbalizar permanece. Ainda que seu dizer nada diga ou que seu silêncio diga

\footnotetext{
277 Ibidem. p. 170.

278 Não que outras ideologias, como o socialismo, não tenham trilhado os mesmos caminhos assentados por esta fé. Em um de seus mais recentes documentários, Into the Inferno (2016), o cineasta Werner Herzog nos apresenta uma Coréia do Norte onde a formação ideológica promovida pelo partido único estabelece uma narrativa capaz de tornar o calendário natural (isto é, dos eventos cataclismáticos do vulcão Baekdu) se correlaciona à própria história social e política do país. De todo modo, a forma como os povos orientais viveram (e ainda vivem) as ideias ocidentais, seja o ideal de progresso próprio de uma sociedade capitalista, seja o ideário de nação presente nos países socialistas, jamais deve ser entendido como uma cópia do que se passou na Europa. Estes povos, cujas vivências e experiências de tempo são absolutamente outras ao tempo linear, vivem, nesta conjunção com o tempo moderno, uma temporalidade plural que, à sua maneira, deve resguardar em seu interior os conflitos antagônicos e as sínteses cosmo-históricas que são a sua particularidade.

279 Ibidem. p. 171.
} 
tudo. Reconhecendo o abismo que se interpõe entre as culturas ocidental e a oriental (e a distância que, muitas vezes, essa designação oculta na pluralidade de culturas que compõe o núcleo de cada hemisfério) Paz comenta a dificuldade de aproximar os termos dos âmbitos opostos, mas insiste que, ao contrário do que propõe Wittgenstein ${ }^{280}$, 'devemos falar': "Quando pensamos estar falando das mesmas coisas com um árabe ou com um esquimó, talvez estejamos falando coisas diferentes; e não seria impossível que o contrário também ocorresse ${ }^{281 "}$. Esta distância entre as culturas desemboca numa dificuldade de tradução: como dizer aquilo que dizem os outros? Ademais, como compreender nos nossos termos sem, com isto, colonizarmos as questões do outro com nossos próprios termos, advindos de nossa própria linguagem e de nossa própria forma de operar logicamente? Paz expõe este paradoxo da seguinte maneira:

\footnotetext{
"não podemos reduzir a um padrão único e unívoco os diferentes significados de todos estes termos mas sabemos que, até certo ponto, eles são análogos. [...] Poderão dizer-me, e com razão, que se não sabemos com segurança o que significam as palavras, menos ainda saberemos a que realidades se referem. [...] Se aceitarmos o parecer da moderna filosofia da linguagem, devemos seguilo até o fim: o que ela nos aconselha é que nos calemos - mas que nos calemos definitivamente. Talvez isto seja o mais racional, mas não é o mais sábio. Assim, pois, sem desdenhar os lógicos, prossigo....282".
}

A resposta para tal paradoxo, cujo sentido é a insistência no dizer, consiste na proposição central do método analógico, que é a de que a relação entre termos só pode ser de oposição ou de afinidade. Alfredo Bosi, em O Ser e o Tempo da Poesia, em sua única menção a Octavio Paz, antes de iniciar, curiosamente, o capítulo sobre a Analogia,

\footnotetext{
280 Acerca do posicionamento dos filósofos da linguagem, bem como daqueles pertencentes o neopositivismo lógico, Octavio Paz denunciará que, muitas vezes, defendem posicionamentos que corroboram para o encrustamento do solipsismo científico: Diz Paz em Conjunções e Disjunções: "O solipsismo científico é uma variante do solipsismo linguístico. Sobre este último, dizia Wittgenstein ser ele legitimo e coerente: "o mundo é meu mundo: isto se manifesta pelo fato de que os limites da linguagem significam os limites do meu mundo... Eu sou meu mundo". Só que esse "eu sou" não é o corpo, mas minha linguagem - a linguagem. Uma linguagem que cada vez menos é minha: é a da ciência" (Op. Cit. 1979. p. 113). Quando a linguagem científica se torna alheia a nós, ela já perdeu a sua capacidade de apresentar algum sentido para além de si mesma.

${ }^{281}$ PAZ, Octavio. Conjunções e Disjunções. Trad. Lucia Teixeira Wisnik. São Paulo: Perspectiva, 1979. p. 40. 282 Ibidem.
} 
reconhece que "lendo Octavio Paz extrai-se o sumo desse desespero em face do enunciado - "los objetos están más allá de las palavras" - sem que se perca a lucidez ao admitir a necessidade do verbo ${ }^{283 \prime \prime}$. O silêncio seria uma possibilidade, porém Paz a recusa: e dessa recusa - lúcida - ao silêncio, surge a sua poesia.

Neste sentido, o que Octavio Paz nos apresenta aqui - e que será corroborado em outras análises, como veremos adiante - pode ser compreendido como um procedimento epistemológico. Ao visualizar tais afinidades ou oposições, Paz parte do pressuposto que os termos linguísticos de uma cultura tendem a se dar de forma bilateral. Cabe dizer que o autor não exclui a possibilidade destas organizações se darem de uma forma que não por pares, uma vez que admite circularidades ou triangulações, por exemplo, quando diz que "há um circuito biopsíquico que vai de vida a sexo a espírito a morte a vida ${ }^{284 "}$. Esta tendência à oposição, já apresentada por nós nos termos de Mircea Eliade como coincidentia oppositorum, para Paz é marca de nossa universalidade. Isto é, o mexicano vislumbra esta operação em todas as culturas e faz de seu método analógico o instrumento decifrador destas coincidências, destas oposições e analogias. A perseverança de Paz na crença da universalidade desta correspondência leva o autor a afirmar que "em vista disso, não é exagero pensar que algum dia possamos construir, no campo das civilizações e tal como Lévi-Strauss e sua escola já o fazem no das sociedades primitivas, uma sintaxe universal ${ }^{285}$ ". A convergência de Paz em relação aos postulados da Antropologia Estrutural motivará o seu livro sobre Lévi-Strauss, que discutiremos no último capítulo desta seção. Mas, independentemente desse conhecimento vir a se constituir de forma científica ou não, cabe dizer que os ensaios de interpretação cultural, bem como os poemas de Paz, transladam estes termos opostos e tornam-se o objeto de seu fazer poético. Em suma, um dos princípios universais que rege este princípio da coincidentia oppositorum consiste na seguinte regra que afirma que o excesso de disjunção ou de conjunção pode destruir um dos polos e, portanto, a relação entre os termos:

\footnotetext{
${ }^{283}$ BOSI, Alfredo. O Ser e o Tempo da Poesia. São Paulo: Companhia das Letras, 2000. p. 38.

${ }^{284}$ Ibidem. p. 41.

$285 \mathrm{Ibidem}$.
} 


\begin{abstract}
"além disso, o predomínio excessivo de um dos termos provoca desequilíbrio: repressão ou relaxamento. Da mesma forma, a igualdade absoluta entre ambos produz a neutralização e, consequentemente, a imobilidade. De tudo isso se deduz que a relação ideal exige, em primeiro lugar, um leve desequilíbrio de forças; a seguir, uma relativa autonomia de cada termo em relação ao outro. [...] O essencial é que a relação não seja tranquila: o diálogo entre oscilação e imobilidade é o que infunde vida à cultura e dá forma à vida ${ }^{286 "}$.
\end{abstract}

Ou seja, os signos devem permanecer como partículas móveis, em rotação, pois só assim se mantém o equilíbrio. Para Octavio Paz, esta harmonia é uma das condições necessárias da existência do próprio erotismo, para o qual os signos corpo e não-corpo em "suas uniões e separações são a [sua] substância [...], aquilo que o distingue da mera sexualidade. Não há erotismo sem referência ao não-corpo, assim como não há religião sem referência ao corpo ${ }^{287 \prime \prime}$. Citando indiretamente Lévi-Strauss, Paz nos lembra qual é o significado e a função deste emaranhado de códigos de símbolos, composto por metáforas, sensíveis e intelectuais, que é a linguagem: sua função é "significar e comunicar os significados ${ }^{288 \prime \prime}$, sem abstrair a característica sensível dos signos, que permite que estes operem sobre os sentidos.

Em suma, absorvendo toda a tradição do pensamento antropológico estrutural, Octavio Paz quer nos lembrar que o método, a racionalidade dos povos "primitivos" (e Paz insere muitas aspas nisso) é "a maneira de associar todos esses signos até tecer com eles séries de objetos simbólicos: o mundo convertido numa linguagem sensível. Dupla maravilha: falar com o corpo e converter a linguagem num corpo ${ }^{289 "}$. A função da arte moderna seria, então, para Paz, a de devolver o corpo à linguagem e a de fazer os caminhos da linguagem encontrarem, novamente, o corpo. É fazer o caminho do rito, onde se comunga do tempo cíclico: ao fazer encarnar as imagens, o poeta fornece "a possibilidade que cada indivíduo tem de recobrar sua porção viva de passado290", de

\footnotetext{
286 Ibidem.

${ }^{287}$ Ibidem. p. 112.

288 Ibidem. p. 17.

289 Ibidem. p. 18

290 Ibidem.
} 
modo que a própria memória se faz desnecessária, uma vez que a imagem nos recobra colocando-nos frente a frente com este passado.

Por isso, é correto pensar que a potência de uma imagem, para além da reminiscência, pode trazer o passado de volta. O desafio, para Paz, é: como fazer voltar estas imagens de uma forma não nostálgica e de uma maneira que nossa sociedade, crítica apaixonada de si mesma, não as anule. Sobre isto, o autor exemplificará que mesmo o budismo, enquanto uma doutrina crítica, não anulou a imagem do corpo, pelo contrário, pois possuía um refinamento dialético que - destarte todo o pessimismo (inerente a todo pensamento crítico) - soube "aceitar e glorificar o corpo $291 "$ :

\footnotetext{
“os relevos esculpidos nos frontispícios de Karli são casais despidos e sorridentes: nem deuses nem demônios, mas seres como nós. [...] A saúde que irradiam seus corpos é natural: a solidez um pouco pesada das montanhas e a graça lenta dos rios fartos $292 "$.
}

Em suma, estas experiências religiosas de conjunção do signo corpo e não-corpo na Índia levam Paz a concluir que "nenhuma civilização criou imagens tão plenas e cabais do que seja o gozo terrestre ${ }^{293 "}$, o que nos leva a questionar nossas imagens e o que a sociedade ocidental produz em suas formas de consagrar o corpo. Para Paz, é preciso devolver esta função consagradora à arte, esta possibilidade de fazer encarnar as imagens, pois

\footnotetext{
“a imagem do corpo é o duplo da do cosmos, a resposta humana ao arquétipo universal não-humano. Cada civilização viu o corpo de uma maneira diferente porque cada uma tinha uma ideia diferente do mundo. [...] Nossa época é crítica: desfez a antiga imagem do mundo e não criou outra ${ }^{294 \prime \prime}$.
}

\footnotetext{
291 Ibidem. p. 38.

292 Ibidem. p. 39.

293 Ibidem.

294 Ibidem. p. 122.
} 
Ou seja, segundo a tradição moderna, trata-se de insistir no mote de embrenhar e fundir no mesmo espaço, as esferas da arte e da vida, tal como se propusera a fazer Rimbaud, os românticos alemães e os surrealistas. Por isso, pensando no método analógico para analisar a relação entre os signos que, até então, discutimos aqui, corpo e não-corpo, cabe questionar: como se configura o corpo hoje na sociedade de consumo globalizada? Qual o sentido de sua imagem? Em comparação à relação que o tantrismo estabelece com o corpo, como poderíamos interpretar o culto ao corpo que, paulatinamente, substituiu todo o ascetismo vigente em boa parte do século XX e que agora se torna cada vez mais um paradigma erótico e político no Ocidente?

Na contemporaneidade, poderíamos incorrer na discussão sobre o diagnóstico foucaultiano acerca da disciplinarização dos corpos e como este opera no sentido da manutenção da ordem através da repressão a toda disfunção da norma. Contudo, cabe discutir como existe uma demanda por corpos fluídos ${ }^{295}$, capazes de se adaptar às mais variadas alternâncias de situação. Corpos ativos, positivos, vibrantes, dispostos ao trabalho. O boom das academias e do mundo "fitness" apontam para este diagnóstico. Quem hoje analisa a sociedade contemporânea e a relação que esta estabelece com o corpo não pode perder de vista que a razão em voga ainda é a lógica do trabalho, porém cada vez mais abstrato, dividido e diversificado.

Para Byung-Chul Han, em A Sociedade do Cansaço, temos que

\begin{abstract}
"a sociedade do século XXI é uma sociedade do desempenho. Também seus habitantes não se chamam mais "sujeitos da obediência", mas sujeitos de desempenho e produção. Nesse sentido, aqueles muros das instituições disciplinares, que delimitam os espaços entre o normal e o anormal, se tornaram arcaicos. A analítica do poder de Foucault não pode descrever as modificações psíquicas e topológicas que se realizaram com a mudança da sociedade disciplinar para a sociedade do desempenho. Também aquele conceito da "sociedade do controle" não dá mais conta de explicar aquela mudança. Ele contém ainda muita negatividade ${ }^{296 \prime \prime}$.
\end{abstract}

\footnotetext{
${ }^{295}$ E não nos referimos aqui à sua acepção segundo as teorias de gênero, tal como pensa a filósofa Judith Butler.

${ }^{296}$ HAN, Byung-Chul. Sociedade do Cansaço, Trad. Enio Paulo Giachini, Petrópolis, Vozes. 2015. p. 24.
} 
De certa forma, o controle dos corpos, o seu processo disciplinar, além de produzir os traumas, os sujeitos neuróticos, psicoatípicos, reprimidos ou recalcados, também não era tão eficaz do ponto de vista das relações dinâmicas de trabalho, oferta generalizada cada vez mais num universo de dominação do trabalho em que o processo de produção se encontra dissolvido em várias etapas. Toda relação de poder envolta no processo de disciplinarização é marcada pela negatividade. Para Byung-Chul Han, o que assistimos hoje é uma transição paulatina da estratégia capitalista de convergir os corpos para a obtenção do lucro. Neste âmbito, o filósofo cita o mote da campanha eleitoral de Barack Obama como um dos exemplos desta transição que se deu sutilmente:

\footnotetext{
“O plural coletivo da afirmação 'Yes, we can' expressa precisamente o caráter de positividade da sociedade de desempenho. No lugar de proibição, mandamento ou lei, entram projeto, iniciativa e motivação. A sociedade disciplinar ainda está dominada pelo 'não'. Sua negatividade gera loucos e delinquentes. A sociedade do desempenho, ao contrário, produz depressivos e fracassados. A mudança de paradigma da sociedade disciplinar para a sociedade de desempenho aponta, contudo, para um nível de continuidade: o desejo de maximizar a produção $297 "$.
}

À medida em que o ônus dos loucos e delinquentes se assomava aos prejuízos gerados pelas empresas, inflamadas por indenizações, processos trabalhistas, etc., é possível afirmar que a astúcia do sistema foi capaz de produzir uma inversão na ordem da responsabilidade pelos resultados da produção. Se a disciplina não é mais capaz de gerar o lucro necessário, é preciso uma nova tecnologia discursiva que opere nos canais mais subjetivos e inconscientes do trabalhador.

Dotado cada vez mais da "liberdade de si", o que pressupõe a liberdade sobre seu corpo, os trabalhadores são submetidos a termos draconianos de produtividade, como os que vemos nas jornadas de trabalho daqueles que já sentem os efeitos da

297 Ibidem. 
"uberização" do trabalho, através dos aplicativos e dispositivos móveis. Neste sentido, subsumir que esta é uma situação de liberdade é obscurecer a coerção social que esta relação pressupõe. Se, por um lado, o papel disciplinar desapareceu, junto com ele foi a própria figura opressora do patrão, substituído pelos algoritmos que gerarão, de forma cambiável, o valor (não mais salário) a ser pago pela jornada - muitas vezes extensiva de trabalho. Contudo, o discurso empreendedor se vale de sua estratégia para imiscuir esta nova ideologia através da figura do trabalhador como "empreendedor de si mesmo", já incapaz de se organizar como classe na imagem do "proletário", uma vez que, nos termos do sociólogo Ruy Braga, a dinâmica dos mercados e as novas relações sociais de trabalho vieram a produzir o "precariado ${ }^{298 " . ~ N e s t e ~ c o n t e x t o, ~ B y u n g-C h u l ~ H a n ~}$ afirma que

\footnotetext{
"para elevar a produtividade, o paradigma da disciplina é substituído pelo do desempenho ou pelo esquema positivo do poder, pois a partir de um determinado nível de produtividade, a negatividade, a proibição tem um efeito de bloqueio, impedindo um maior crescimento. A positividade do poder é bem mais eficiente que a negatividade do dever ${ }^{299} . "$
}

Neste universo material, para Byung-Chul Han, o culto ao corpo se tornou também um culto à saúde. Entretanto, a concepção de saúde a que a sociedade contemporânea oferece devoção é uma concepção racionalizada, ou seja, cientificista.

Para o sul-coreano, o corpo não é depositário de sentido, não é compreendido no interior das relações eróticas, mas é escamoteado e subsumido ao princípio do lucro e da eficiência. Neste sentido, o corpo só ganha relevância uma vez que é capaz de potencializar a produção e o ganho, no interior das empresas. Isto explica o boom dos discursos motivacionais, assim como das técnicas de coaching que operam no sentido de aumentar o período de atividade do trabalhador, enquanto dispositivo ideológico.

\footnotetext{
${ }^{298}$ CF. BRAGA, Ruy. A rebeldia do precariado: trabalho e neoliberalismo no Sul global. São Paulo: Boitempo Editorial, 2017.

${ }^{299}$ HAN, Byung-Chul. Ibidem. p. 25.
} 
Portanto, ao inserir toda essa semiologia de signos incorpóreos, fazendo desaparecer a polaridade, na emergência deste "novo" signo corpo, temos, para o filósofo que

\begin{abstract}
"a vida enquanto um sobreviver acaba levando à histeria da saúde. A pessoa sadia irradia paradoxalmente um quê de mórbido, algo de sem-vida. Sem a negatividade da morte a vida enrijece em morte. A negatividade é a força vital da vida. [...] A sociedade atual do sobreviver que absolutiza o sadio, destrói precisamente o belo. A mera vida sadia, que hoje adota a forma do sobreviver histérico, converte-se no morto; sem, num morto-vivo. Nós nos transformamos em zumbis saudáveis e fitness, zumbis do desempenho e do botox. Assim hoje, estamos por demais mortos para viver, e por demais vivos para morrer ${ }^{300 "}$.
\end{abstract}

O corpo morto-vivo pode ser compreendido como o corpo onde a hipérbole do signo corpo não veio acompanhado de um contingente de significação de seu correlato, o signo não-corpo, a ele imantado e inerente nesta relação. Trata-se de um caso em que a disjunção operou uma construção bizarra: a imagem do zumbi. Isto é, o trabalhador que cultua o ideal de saúde, mas cuja própria vida é esvaziada de sentido, uma vez que a própria saúde é subalterna ao trabalho. Enquanto cultuamos o corpo, estamos, na verdade, cultuando o trabalho num dos mais sutis e recentes processos de alienação. A vitória do signo não-corpo ocorre, estranhamente, através do próprio signo corpo.

Entretanto, na escrita de Conjunções e Disjunções, Octavio Paz demonstra sua atenção a estes fenômenos e apresenta o seu diagnóstico. Diz Paz:

"o novo materialismo afirma, com ênfase igual à das antigas religiões, que possui a chave do universo. É possível que a tenha, mas também é certo que não nos pôde dar uma imagem deste mundo nem a de outros. Seu universo não tem corpo e sua matéria é abstrata e incorpórea como uma ideia. Sua ciência nos diz como funcionam os órgãos genitais e nos ensinou mais a esse respeito que todos os Kamasutras e os Tratados do leito. Por outro lado, não nos deu uma erótica: em seus manuais as palavras prazer e imaginação foram

300 Ibidem. p. 118. 
substituídas por orgasmo e saúde. [...] Ensinam-nos a ser normais mas não a nos enamorarmos nem a nos apaixonarmos. Nada mais distante de uma arte de amar. Ao nos explicar como se constitui o corpo e como funciona, anulam sua imagem. A tudo isto deve-se acrescentar a voga dos esportes, que introduziu uma confusão entre vigor e beleza, destreza física e sabedoria erótica ${ }^{301 " \text { ". }}$

A partir desta explicação de Paz, podemos indicar que o culto ao corpo não se distingue de sua própria anulação. Trata-se da morte do mesmo, sua conversão em técnica. Portanto, se a nossa relação com a festa, hoje, é uma relação de praticidade, uma relação orientada a fins, a própria experiência da festa já se perdeu. Quando é assim, vivemos absorvendo restos mortais de experiências de onde apenas nos sobraram práticas desbotadas, vivências sem vivacidade.

Poderíamos dizer que, nos termos de Byung-Chul Han, a sociedade do desempenho suaviza, na aparência, os polos extremos da disjunção radical corpo e nãocorpo, pois reinsere o corpo na esfera do dia, do cotidiano. Ainda que a sociedade do desempenho, sob a forma do consumo, mantenha uma postura de culto ao corpo, ao torna-lo algo submisso ao processo de desempenho, ao incutir nele a abstração da produtividade, torna essa flexão ainda mais rígida e distante do erotismo e da experiência real, afetiva, de contato do um com o outro. Não obstante, este impacto se sente tão diretamente nas relações erótico-afetivo-sociais. Octavio Paz reconhece que é isso o que ocorre no Ocidente, mas acrescenta:

\footnotetext{
“não apesar de nosso materialismo, mas justamente por causa dele. Trata-se de um materialismo abstrato, uma espécie de platonismo às avessas, desencarnado como a vacuidade do Buda. Já nem sequer provoca a resposta do corpo: deslizou sobre ele e, como um vampiro, chupa-lhe o sangue. Basta folhear uma revista de modas para comprovar o estado lastimável a que o novo
}

${ }^{301}$ PAZ, Octavio. Ibidem. p. 118. 
materialismo reduziu a forma humana: os corpos dessas jovens são a própria imagem do ascetismo, da privação e do jejum ${ }^{302 " \text {. }}$

Ainda que o modelo dos corpos aqui pensados seja distinto: Paz pensa nas modelos que, muitas vezes, sofrem de anorexia para aderir ao sintomático corpo magro dos manequins e Byung-Chul Han pensa no corpo das academias que proliferam nas grandes metrópoles, bem como nas redes sociais, quanto mais imagéticas forem. Entretanto, a ideia de saúde que vigora em um não é menos estéril que o padrão mortificado imposto à outra, uma vez que em ambos os casos os paradigmas de imagem carecem de sentido erótico. Ora, visto que o elemento principal da festa são os corpos e o movimento que estes realizam na dança, como pensar a festa sem corpos realmente vivos?

Para que haja a experiência da festa, é necessário uma ruptura temporal, daí seu caráter de revolta, pois se trata de uma rebelião às imposições ordeiras do mundo do trabalho, do mundo que Han chama de "pro-fano (literalmente: o que se localiza antes das cercanias sagradas) ${ }^{303 ”}$. Isto é, uma vez na festa, então se é consagrado no tempo celebrativo desta. Pois, para o filósofo, "quando se suspende aquele umbral, aquela passagem, aquela consagração que separa o sagrado do profano, restará ainda apenas o tempo cotidiano, passageiro, que então será explorado como tempo de trabalho ${ }^{304 " .}$ Contudo, entre festa e cotidiano, haverá a cisão, a ruptura necessária, sem a incorporação do primeiro no segundo, sob a justificativa da otimização da produtividade. Para que esta cisão se mantenha, é extremamente importante que a experiência de tempo seja diferente e para atestá-lo basta a nossa percepção. Ademais, para Paz, a cerimônia da celebração ou da festa também é uma experiência do tempo misto, do tempo plural. Em Conjunções e Disjunções, ele diz que

\footnotetext{
“a cerimônia comemora uma ausência ou, mais exatamente, convoca, conjura e castiga, tudo ao mesmo tempo, uma Ausente. A Ausente tem um nome público e outro secreto: o primeiro é Revolução e alude ao tempo linear da
}

\footnotetext{
302 Ibidem. p. 107.

${ }^{303}$ HAN, Byung-Chul. Ibidem. 113.

304 Ibidem.
} 
história; o outro é Festa e evoca o tempo circular do mito. São um e o mesmo: a Revolução que retorna é a Festa, o princípio do princípio que regressa. Só que não retornam realmente: tudo é pantomima e, no dia seguinte, jejum e penitência. Festa da deusa razão - sem Robespierre nem guilhotina mas com gás lacrimogênio e televisão. A Revolta como orgia verbal, saturnal de lugares comuns. Náuseas da Festa".

Pantomima da revolução ou paródia são signos cuja força motriz foi a ironia. A celebração da festa ou mesmo da Revolução na contemporaneidade atende à concepção que temos de "futuro do presente" ou pós-utopia ${ }^{305}$. Não arcamos mais com o preço das utopias cujas constelações residiam no futuro inacessível. As demandas do presente articulam as suas pautas para o dia de hoje: fixam-se na agoridade. Por isso, a Revolta é tão frequente no interior das democracias. Porém, por outro lado, falta-lhe conteúdo programático, panorama ou mesmo perspectiva de continuidade, uma vez que seu caráter é a explosão da espontaneidade, seu fenômeno é imediato, dependendo de uma correlação de forças que, dificilmente, se mobiliza e articula ${ }^{306}$.

Entretanto, a própria noção de utopia pode ser ressignificada, se levarmos em conta a sua correlação à ideia de corpo que a fundamenta. Ao pensar como as utopias se relacionam com os corpos, Michel Foucault partirá da afirmação de que estas construções teóricas surgiram no sentido de fazê-lo sumir, impondo uma realidade

\footnotetext{
${ }^{305}$ Conceito que pertence, originalmente, a Haroldo de Campos, cuja formulação levou em conta o que este considerava, em consonância com Octavio Paz, a falência das ideologias políticas do século XX, como o socialismo. Recentemente, o poeta Augusto de Campos, parceiro e irmão do poeta e teórico, no grupo Noigrandres, em entrevista por ocasião do lançamento de seu livro de poemas Outro, declarou acerca das utopias que "Haroldo plantou o seu conceito de pós-utópico na falência das utopias ideológicas no século passado. Achava que não havia mais motivação para movimentos. Daí a sua idéia de "agoridade". Eu sou mais renitente quanto às utopias, acho que merecemos continuar apostando nelas, por mais que os fatos nos desanimem. Sou mais pessimista com o "agora". Temo que sirva de abrigo a retornos indesejáveis. Meu lema é: ser radical sem ser fanático, aberto sem ser eclético". (UBIRATAN Brasil. Aos 84 anos, Augusto de Campos lança novo livro de poemas. São Paulo: O Estado de São Paulo. 2015. Disponível em: https://cultura.estadao.com.br/noticias/literatura,aos-84-anos--augusto-de-campos-lanca-novo-livrode-poemas-1736062). Em suma, é preciso ter em vista que, da mesma forma que podemos desconfiar das promessas eletivas de futuro, também se faz necessário a observância em relação ao retorno do reprimido e das mais antigas pulsões de morte.

${ }^{306}$ Poderíamos pensar, como exemplo, as Manifestações de Junho de 2013 no Brasil, cuja adesão às ruas foi motivada por uma série de fatores que escapavam às motivações originais dos protestos daquele ano: a redução do preço da tarifa do transporte público da cidade de São Paulo.
} 
abstrata que os idealizou em figuras intangíveis. Em O Corpo Utópico, Foucault afirma que utopia é um

\footnotetext{
"lugar fora de todos os lugares, mas um lugar onde eu teria um corpo sem corpo, um corpo que seria belo, límpido, transparente, luminoso, veloz, colossal na sua potência, infinito na sua duração, solto, invisível, protegido, sempre transfigurado; pode bem ser que a utopia primeira, a mais inextirpável no coração dos homens, consista precisamente na utopia de um corpo incorporal ${ }^{307 "}$.
}

O corpo incorpóreo é, pois, um corpo que é despossuído de si mesmo, um corpo que não possui uma característica de corpo. Essa descorporificação se exemplifica pela figura arcaica da múmia. Para Foucault, a múmia é a figura que foi descorporificada para que pudesse atingir o além-vida, a utopia do mundo divino, mas que, para tanto, teve de ser exumada de suas vísceras e de tudo o que constituísse uma parcela de imperfeição ou de tragável pela decomposição inerente do tempo.

Porém, adiante, neste mesmo texto, o francês reconsiderará e nos dirá que, na verdade, toda ideia de utopia foi calcada numa imagem de corpo, foi a afirmação de uma determinada verdade acerca deste corpo, afirmação que muitas vezes, porém, volta-se contra o próprio corpo. “O corpo humano é ator principal de todas as utopias $^{308 ",}$ daí que nossas criações, como a máscara, a tatuagem, a pintura, a maquiagem, etc. sejam manifestações de utopias "seladas no corpo", isto é, sejam a ele inerentes. A compreensão que Foucault nos oferece acerca da ideia de utopia é a de um universo imaginário que estabelece uma conexão direta, através da afirmação ou da negação, com o corpo. Se há algo no ideário de progresso ou nas promessas de felicidade presentes no comunismo, que possamos classificar como utópico, é o fato de que tanto em um como em outro, temos crença na capacidade da técnica e da reorganização da divisão do trabalho produzir o deslumbramento de uma sociedade em

\footnotetext{
307 FOUCAULT, Michel. O corpo utópico, As heterotopias. Trad. Salma Tannus Muchail. São Paulo: N-1 Edições, 2013. p. 8.

${ }^{308}$ Ibidem. p. 12.
} 
que, finalmente, o corpo estaria livre do jugo do trabalho. Aliás, é esta ideia de utopia que Paz dirá ser irrenunciável, destarte apenas a sua infinita projeção, uma vez que para o autor deveríamos focar na sua realização presente, no espaço do aqui e do agora.

Mas, por fim, Foucault dirá que se, por um lado, a experiência originariamente utópica do corpo é possível apenas graças ao Espelho e à Morte - pois, através deles, eu consigo vislumbrar a ideia de corpo como sendo algo que possuo, junto de sua forma e seu contorno -, por outro, é graças a estas mesmas duas ideias que o nosso corpo não é reduzido à utopia. Para Foucault,

\footnotetext{
"se considerarmos que a imagem do espelho está alojada para nós em um espaço inacessível, e que jamais poderemos estar lá onde estará nosso cadáver, se considerarmos que o cadáver e o espelho estão, eles próprios, em um inatingível outro lugar, descobrimos então que unicamente as utopias podem fazer refluir nelas mesmas e esconder por um instante a utopia profunda e soberana de nosso corpo ${ }^{309 \prime \prime}$.
}

Ao final de seu texto, Foucault dirá que existe apenas um tipo de experiência em que a utopia não se conjuga no corpo, a experiência do amor, pois ela representa o sentido total da presença.

Por fim, cabe explicitar que, para Han, cabe resgatar das obras de arte seu aspecto de celebração. Ainda que estas tenham perdido o seu valor de culto na modernidade, as imagens artísticas e poéticas podem oferecer mais do que a mera relação de entretenimento:

\footnotetext{
“Culto e festa estão estreitamente interligados. Arte originária é para Nietzsche a arte da festa. [...] Originalmente, obras de arte são monumentos do tempo de celebração. [...] Museus e cofres bancários são depósitos de ossadas de arte. São lugares do tempo-zero, sim, do não-tempo ${ }^{310 "}$.
}

\footnotetext{
309 Ibidem. p. 15.

${ }^{310}$ HAN, Byung-Chul. Ibidem. p. 125.
} 
Por conta desta capacidade da festa de reafirmar outra realidade temporal, Paz reconhecerá que a festa mexicana resguarda a pluralidade, destarte os conflitos em que a própria sociedade se enreda. Em Sor Juana Inés de la Cruz, o poeta afirmará que, graças a toda a complexidade da formação histórica - justaposta - como explicamos anteriormente, nos povos hispânicos

\footnotetext{
"as épocas e os estilos não passam: coexistem uns ao lado dos outros, alimentam-se e devoram-se mutuamente... Na festa mexicana confluem muitas correntes e por isso não poucas vezes se manifesta como uma explosão. Irrupção não só de formas, mas de espaços e tempos históricos. Ainda está por se escrever a história da festa no México ${ }^{311 "}$.
}

Ainda que Paz não tenha realizado a escritura de uma história das festas, é certo que o seu trabalho biográfico só se tornou possível graças a uma concepção de história que, por sua vez, é complementar a uma ideia radical de temporalidade.

Se o museu e o mausoléu estão interligados, como colocado na citação de ByungChul Han, a subterraneidade do cofre é interligada ao esgoto, por outro lado. Na crítica ao progresso e à fabricação de produtos desprovidos de sentido, como as obras de arte convertidas em mercadoria, há também uma crítica de certas construções da civilização ocidental que nos escapam à primeira vista. Nesse âmbito, para Paz, haveria uma conexão entre os signos cara e cu, assim como entre fezes e ouro, que ignoramos. Em Conjunções e Disjunções, Paz dirá que o W.C. é uma criação do mundo moderno. Ao citar Norman Brown, o mexicano apresenta o relato de que para os antigos na Índia, as fezes possuíam uma correlação com o Sol e, por consequência, com as pedras que the reluziam. Entretanto, a merda era ambivalente:

${ }^{311}$ PAZ, Octavio. Sor Juana Inés de la Cruz ou As armadilhas da fé. Trad. Wladir Dupont. São Paulo: Ubu Editora, 2017. P. 179. 


\begin{abstract}
“a economia racional capitalista é limpa, útil e moral: é o sacrifício da omissão [...] que fazem os bons ante a vontade divina. A recompensa da divindade não se manifesta em bens materiais mas em signos: moeda abstrata. [...] Possui uma dupla virtude: a de ser mercadoria e também o signo de todas as mercadorias. A moralização do ouro e sua transmutação em signo é paralela à expulsão das palavras sujas da linguagem e à invenção e popularização do "reservado" inglês. O banco e o W.C. são expressões típicas do capitalismo ${ }^{312 " . ~}$
\end{abstract}

Ainda que este par excremento-ouro nos cause espanto, é curioso que Octavio Paz não tenha aqui se recordado da obra Merda de Artista do artista italiano Piero Manzoni. Nesta obra, composta por uma série de noventa latas, guardando excrementos de seu autor, o artista as vendia, justamente, ao preço do peso do ouro. Podemos afirmar que, dessa forma, ao transformar sua merda em signo abstrato - o valor de troca -, de uma forma irônica que nos remete diretamente a Marcel Duchamp, o artista reestabelecia o par obscurecido, porém, desta vez, esvaziando o sentido abstrato do próprio ouro, de uma forma crítica. Trata-se de um procedimento similar à crítica da crítica empreendida por Duchamp: através da metaironia, restabelecer no campo da vida, a analogia, uma vez que "para Duchamp, a arte, todas as artes, obedece à mesma lei: a metaironia é inerente ao próprio espírito. É uma ironia que destrói sua própria negação e, assim, se torna afirmativa313". Uma negação que desemboca em outra coisa.

Assim como em suas outras obras, o ensaio Marcel Duchamp ou o Castelo da Pureza também iniciará com uma exortação à questão do tempo, presente em todas as obras. Para Octavio Paz, dois dos principais artistas da modernidade são Pablo Picasso e Marcel Duchamp, pois são artistas que possibilitam que as imagens encarnem e que "em suas telas e em seus objetos o espírito moderno se torna visível e palpável; profecias: em suas mudanças nosso tempo só se afirma para negar-se e só se nega para inventarse e ir mais além de si ${ }^{314 "}$. Como Marcel Duchamp, um autor marcado pela sua veia crítica e pela tessitura intelectual de suas obras, pode ser, nos termos que compreendemos anteriormente acerca do sentido da encarnação, um artista que faça

\footnotetext{
312 PAZ, Octavio. Conjunções e Disjunções. Trad. Lucia Teixeira Wisnik. São Paulo: Perspectiva, 1979. p. 27. 313 PAZ, Octavio. Marcel Duchamp ou o castelo da pureza. Trad. Sebastião Uchoa Leite. São Paulo: Ed. Perspectiva, 2008. p. 11.

314 Ibidem. p. 7.
} 
vicejar o corpo? Paz reconhece, já no início do seu ensaio, que Duchamp é marcadamente um 'pintor de ideias', mesmo em sua fase "cubista-analítica", quando pinta Nu Descendo uma Escada e Moinho de Café, pois não se restringe à pintura como uma arte meramente visual, retiniana. A rebelião de Duchamp, na ótica de Paz, é contra este tipo de arte, ainda que principie se valendo dela. E é esta que vamos analisar agora. 


\section{Marcel Duchamp: o mito da crítica e a crítica do mito}

Como toda rebelião, a de Duchamp é motivada e Paz encontra nesta motivação uma origem de ordem verbal, que nos possibilita classifica-lo como "escritor". Segundo Paz, diz o francês,

\footnotetext{
“"Rimbaud e Lautréamont pareciam demasiado velhos naquela época. Queria algo mais jovem. Mallarmé e Laforgue estavam mais próximos do meu gosto". [...] Esta confissão lança luz suficiente sobre a origem verbal de sua criação pictórica. Seu fascínio diante da linguagem é de ordem intelectual: é o instrumento mais perfeito para produzir significados e, também, para destruí$\operatorname{los}^{315 \prime \prime}$.
}

No entanto, acreditamos que cabe questionar os motivos pelos quais, dentre os vanguardistas da modernidade, Paz a escolheu Duchamp como tema de um ensaio.

Por que Duchamp? O que leva Paz a escolhê-lo como o artista da vida moderna por excelência, da mesma forma que Baudelaire, em seu ensaio de mesmo tema, escolhe o pintor francês Constantin Guys? A nosso ver, para Paz, Duchamp se torna o modelo, merecedor de um ensaio que explorará certos limites de suas obras, pois este coloca no centro de seu fazer artístico o mesmo objeto artístico dos poetas. Oscilando entre a criação e a destruição, a linguagem será o tema central da antiarte de Marcel Duchamp. Isto o torna um "anti-pintor" que é, ao mesmo tempo, poeta, mas que é, outrossim, filósofo. Paz diz que pelas mãos de Duchamp a pintura se converte em uma “cartografia simbólica e o objeto em ideia. Esta redução implacável não é realmente um sistema de pintura, mas um método de investigação interior. Não a filosofia da pintura: a pintura como filosofia316". Mas não só: Duchamp talvez seja um dos pintores que mais abraça a modernidade no melhor sentido da tradição da ruptura, ao negá-la de uma forma sui generis. Os ready-mades podem ser encarados como um exemplo disto. Nestes objetos que nada mais são do que a expressão de sua linguagem, Duchamp força

\footnotetext{
315 Ibidem. p. 11.

316 Ibidem. p. 15.
} 
a contradição e a mantém na evidência. Assim, temos um mecanismo nos leva à imobilidade, um utensílio que é obsoleto - inútil: um inutensílio. Paz diz que

\footnotetext{
“as máquinas são agentes de destruição e daí que os únicos mecanismos que apaixonam Duchamp sejam os que funcionam de um modo imprevisível - os antimecanismos. Esses aparelhos são os duplos dos jogos de palavras: seu funcionamento insólito os nulifica como máquinas ${ }^{317 "}$.
}

Tratam-se, por assim dizer, de "anti-obras" que rejeitam, apesar de todo o processo de canonização ulterior inerente ao processo de institucionalização da arte moderna, o título de obra e colocam esta categoria em questão. Além disso, elevam ao centro da obra de arte a categoria de acidente, de forma a banaliza-la: se o porta-garrafas faz estas se esvaziarem, não seria a técnica - promessa de uma vida confortável e livre dos grilhões do trabalho - um correlato do inutensílio?

Porém, ainda que institucionalizados e canonizados no interior da historiografia da arte, neutralizados pela dialética entre tradição e ruptura, reconhecida por Paz em Os Filhos do Barro, o poeta afirma que a ordem irônica tende "a impedir a confusão entre eles [os ready-mades] e os objetos artísticos ${ }^{318 "}$. Conquista da ruptura? Talvez, mas podemos compreender a persistência desta confusão não apenas como uma vitória do artista e sua motivação rebelde - como um demolidor da linguagem, mas também como um trunfo da metaironia que ainda se encontra presente em suas obras. $\mathrm{O}$ efeito de choque pode ter sido anestesiado pela institucionalização do museu e da obra de arte, em seu papel de culto, mas a contradição interna dos signos presentes na obra nos impede - ainda que haja uma tendência a vislumbrá-las desta forma - de vê-las como obra. A ironia é uma luz que desnuda o seu procedimento de composição. A metaironia é uma luz que desnuda o espaço de fruição da obra de arte, recursivamente, enrubescendo não apenas a obra, mas seu espectador e o espaço onde este se encontra.

\footnotetext{
317 Ibidem. p. 13.

318 Ibidem. p. 20.
} 
A vitória da metaironia é um trunfo não apenas do ponto de vista estético, mas moral. Acerca dela, Paz afirma que

\footnotetext{
"os ready-made são objetos anônimos que o gesto gratuito do artista, pelo único fato de escolhê-los, converte em obra de arte. Ao mesmo tempo, esse gesto dissolve a noção de obra. A contradição é a essência do ato; é o equivalente plástico do jogo de palavras: este destrói o significado, aquele a ideia de valor ${ }^{319 "}$.
}

Cabe questionar, então, qual valor? O ready-made não se prostra como uma nova origem, uma nova narrativa - pelo contrário, a narratividade lhe escapa, tampouco se propõe uma nova fundação de valores, pois consagra o único valor que a modernidade reconhece como universal: a crítica. Esta proposição de Duchamp, aliás, é um dos principais motivos pelos quais Octavio Paz se interessa pelo artista, pois, antes de ser um interventor da realidade sensível, Marcel Duchamp é um crítico: do pensamento, da pintura e da própria linguagem. Para o mexicano, na anti-narratividade de Duchamp,:

\footnotetext{
“o ready-made não postula um valor novo: é um dardo contra o que chamamos valioso. É critica ativa: um pontapé contra a obra de arte sentada em seu pedestal de adjetivos. A ação crítica se desdobra em dois momentos. O primeiro é de ordem higiênica, um asseio intelectual: o ready-made é uma crítica do gosto; o segundo é um ataque à noção de obra de arte $320 "$.
}

Crítico do gosto - e de como o seu estabelecimento neutraliza a crítica -, pois o mesmo não passa de "uma noção epidérmica da arte, no sentido sensual e no social: um prurido e um signo de distinção $321 "$, Duchamp limita o número de ready-made, no intuito de não fomentar a repetição da forma, o que resultaria numa nova proposição em defesa do gosto, possibilitado pela perda da neutralidade. Convém notar aqui que a neutralidade

\footnotetext{
319 Ibidem. p. 23.

320 Ibidem.

321 Ibidem. p. 25.
} 
é o que nos resguarda do gosto, pois entre ela e o choque (ou irritabilidade, como destaca Paz) há uma conexão.

Entretanto, se pensarmos, na esteira do dadaísmo, as formas artísticas que prosseguem no pós-Guerra, encontraremos em Andy Warhol um artista que nos revela o inverso: a neutralidade torna-se totalmente possível graças à repetição e, ao contrário do que pretendia Duchamp com os ready-made, as séries de Warhol, ao se repetirem e ao deslocarem a neutralidade da obra para o olhar do espectador - antes acometido pelo choque, pela confusão e pelo desconforto inerente às obras metaironicas nulificam o efeito de choque possibilitado pela forma. Sobre este ponto, Octavio Paz discorda, ao considerar que o humor pop

\footnotetext{
"carece de agressividade e [que] suas profanações não estão inspiradas na negação e no sacrilégio, mas em algo que Nicolás Calas define como o "e por que não?" (why not?). Tampouco é uma revolta metafísica; no fundo é passivo e conformista ${ }^{322 "}$.
}

Cabe, inclusive, dizer que o autor chega a ser duro, ao considerar, sem nomear Andy Warhol, mas nomes como Jasper Johns e Robert Rauschenberg, um "populismo de gente acomodada", mas não isento de "self-pity ${ }^{323 " . ~ I n c o m o d a-o ~ t a m b e ́ m ~ a ~ f o r m a ~ c o m o ~}$ a pintura pop foi incorporada pelos mercados e pela sociedade que a enxerga como mero título de consumo, tanto que faz coro a Duchamp, quando este lamenta que "o pintor se integrou completamente à sociedade atual, já não é um pária...324".

No mais, podemos considerar que o deslocamento da neutralidade do choque para os olhos do espectador revela que a ironia do gesto estético ainda permanece. Porém, esta ironia não visa mais a nos revelar a impotência da categoria obra de arteensimesmada em formas dependentes de conteúdo, como na arte retiniana já criticada pelo francês - mas talvez revele nossa incapacidade, mediante a reprodução constante de certas imagens, muitas vezes violentas, decorrente de uma superinflação que outrora

\footnotetext{
322 Ibidem. p. 56.

323 Ibidem. p. 57.

324 Ibidem. p. 58.
} 
chocariam a sensibilidade, de obter o efeito de choque ou mesmo de nos comovermos com cenas trágicas. Senão pela esteira do trauma, é impossível sensibilizar-se: eis o efeito da superabundância das imagens inertes e impenetráveis, como os acidentes da série Car Crash de Andy Warhol, cuja disposição em uma forma chapada não apenas nos impossibilita a imersão (ou recuo) mas nos aprisiona no interior de um instante traumático e cíclico, pois repetitivo, incapaz de produzir o choque. Segundo Hal Foster, para Peter Bürger, a repetição é justamente aquilo que impele uma obra de arte transgressiva à institucionalização ${ }^{325}$. Entretanto, ao assimilar a forma de seu tempo, o gesto repetitivo de Warhol torna-se semelhante ao de Duchamp, onde dispor as imagens, repetidamente, como Warhol faz em toda Death and Disaster series desnuda, graças à recursividade, nossa incapacidade de choque e, com isso, demarca nosso lugar no prisma dos afetos. Trata-se, portanto, de um gesto repetitivo que gera uma denúncia sobre o caráter das imagens que povoam nosso cotidiano e nossa sensibilidade. Por que não nos chocamos mais? Para Hal Foster, em The returno of the real,

\footnotetext{
"In context, then, the two statements read as preemtive embrace of the compulsion to repeat put into play by a society of serial production and consumption. If you can't beat it, Warhol suggests, join it. More, if you enter totally, you might expose it; that is, you might reveal its automatism, its autism, through your own excessive example ${ }^{326 \prime \prime}$ (negrito nosso).
}

Portanto, ao contrário do que pensa Paz, é possível ver na pop art, sobretudo a de Warhol, a permanência deste gesto crítico, porém, de uma forma mais sutil e num contexto em que a ironia não é mais a exceção disruptiva, mas a regra de boa parte da arte contemporânea (para não dizermos da própria publicidade), o que torna o seu distanciamento ainda mais necessário, se quisermos que ela venha a operar alguma espécie de efeito contraditório. O gesto repetitivo em Warhol torna-se capaz de revelar o automatismo a que estamos inseridos. Como um vírus que afeta o sistema

\footnotetext{
${ }^{325}$ FOSTER, HAL. The return of the real: the avant-gard at the end of the century. Massachusetts: The MIT press. 1996. p. 11.

326 Ibidem. 131.
} 
imunológico, a crítica irônica permite que, quanto mais integrado à coisa ela está, mais esta se encontra exposta.

O que sustenta a indiferença visual em algumas obras de Duchamp é também o fato de que, em sua obra O Grande Vidro, vemos conteúdos que nos levam a oximoros. Como pode, neste caso, um sistema mecânico corresponder a uma relação erótica? Assim como a maioria dos temas trabalhados pelo pintor, a técnica moderna surge aqui como uma questão, segundo a leitura de Octavio Paz. Para explicá-lo, o mexicano retomou a reflexão de Heidegger acerca do tema, onde afirmou que

\footnotetext{
“a técnica é a natureza do homem moderno: nosso ambiente e nosso horizonte. Certo, toda obra humana é negação da natureza; do mesmo modo, é uma ponte entre ela e nós. A técnica transforma a natureza de uma maneira mais radical e decisiva: desalojando-a. O famoso retorno à natureza é uma prova de que entre ela e nós se interpõe o mundo da técnica: não uma ponte, mas uma muralha. Heidegger diz que a técnica é niilista porque é a expressão mais perfeita e ativa da vontade de poder ${ }^{327 \prime \prime}$.
}

Mais precisamente, o que Heidegger compreende por técnica pode ser exposto da seguinte forma: a técnica é um modo de desvelamento do Ser que o ser humano assume para si. Por isso, ela não é meramente um produto humano - não é as consequências dos processos de subjetivação, consequentemente, não pode ser interpretada apenas do ponto de vista antropológico ou humanista. A técnica é uma alétheia e, como tal, oferece ao ser humano a possibilidade de uma relação com o mundo. Nesta relação, o ser humano pode vir a ser senhor do mundo, desde que assuma que não é um "ser fechado em si mesmo, mas se define pela sua abertura ao ser ${ }^{328 " .}$ Em $A$ Questão da Técnica, o alemão associa o modo de desvelamento da técnica moderna a uma

\footnotetext{
327 PAZ, Octavio. Ibidem. p. 28.

${ }^{328}$ LEOPOLDO E SILVA, Franklin. Martin Heidegger e a técnica. São Paulo: Scientiae Studia. V. 5, № 3, 2007. p. 373.
} 
"armação". Heidegger diz: "Armação significa o modo de desabrigar que impera na essência da técnica moderna e não é propriamente nada de técnico ${ }^{329 " .}$.

Duchamp não se enamora da técnica, mas tampouco lhe faz obstrução de um ponto de vista subjetivista. Ao torná-la a matéria/conteúdo de que se serve, o artista não rompe com a armação posta, mas se torna o senhor da relação que o sujeito estabelece com a técnica. Ao manter a armação, ao "cumprir o seu destino" - pois, segundo Heidegger, a "técnica é um destino que se oferece ao homem - e ele deve cumprí-lo330" -, Duchamp torna-se livre para, inclusive, negá-la. Em termos heideggerianos, é possível dizer que $O$ Grande Vidro é uma obra que ouve o apelo da técnica, mas não se deixa submergir nela. Ao negar a técnica, mesmo se valendo dela artimanha astuta possibilitada pelo recurso metairônico -, Duchamp coloca no centro não apenas este imperativo dos modos de desvelamento possíveis, mas insere outro que é tão imperativo quanto a técnica: a razão crítica. Octavio Paz reconhece que a relação entre Duchamp e a técnica é alocada sob a operação da negação:

\footnotetext{
“dessa perspectiva, o ready-made é uma dupla negação: não só o gesto mas o próprio objeto negativo. Embora Duchamp não tenha a menor nostalgia dos paraísos ou infernos naturais, tampouco é um adorador da técnica. A injeção de ironia nega a técnica porque o objeto manufaturado se converte em readymade: uma coisa inútil ${ }^{331 "}$.
}

Podemos dizer que a dupla negação utilizada por Duchamp possibilita uma evidenciação da técnica. Trata-se de pô-la a nu. O que Heidegger faz em relação à técnica, ao se questionar sobre sua essência, é abrir uma clareira, perscrutando seu sentido históricoontológico já definido. Para Franklin Leopoldo e Silva, o desenvolvimento deste pensamento requer que vislumbremos que "[...] essa mesma compreensão abre possibilidades de um outro modo de pensar, que não recuse a técnica, que não alimente

\footnotetext{
${ }^{329}$ HEIDEGGER, Martin. A questão da técnica. Trad. Marco Aurélio Werle. São Paulo: Scientiae Studia. V. 5, № 3, 2007. p. 385.

330 Ibidem.

${ }^{331}$ PAZ, Octavio. Marcel Duchamp ou o castelo da pureza. Trad. Sebastião Uchoa Leite. São Paulo: Ed. Perspectiva, 2008. p. 28.
} 
nostalgias, mas que faça da técnica que nos domina uma questão a ser enfrentada com a liberdade possível ${ }^{332 "}$. Ora, Paz parte desta questão aventada por Heidegger. É possível ver em sua leitura acerca da linguagem duchampiana uma espécie de reconhecimento das clareiras abertas pela metaironia, pelo processo mútuo de negações, como "um niilismo que gira sobre si mesmo e se refuta: entroniza uma ninharia e, uma vez em seu trono, [decide] negá-la e negar-se a si mesmo ${ }^{333 \prime \prime}$.

A principal obra de Duchamp que Paz analisa é La mariée mise à nu par ses célibataires même, mais conhecida como O Grande Vidro. Octavio Paz a considera um texto hermético, a principiar pelo título:

\footnotetext{
"mise à nu" indica uma expressão "muito mais enérgica que nosso particípio: posta a nu, ex-posta"; a escolha da palavra célibataire (solteiro), no plural, precedida pelo possessivo, o que acentua a inferioridade dos machos em questão - "o solteiro não é nem sequer pretendente e a noiva nunca será desposada" [...] e seu caráter de rebanho. Para Paz, a importância do título já indica todos os elementos da obra: "o mítico ou religioso, o popular de barraca ou tenda de feira, o erótico e o pseudotécnico ou irônico ${ }^{334 ” .}$
}

Como já afirmamos, a inserção da técnica neste regime de linguagem metairônica possibilita uma abertura de significação. No caso, a abertura é a do par erotismo e técnica. Este binarismo, presente na obra, só é possível graças ao papel da Noiva. Segundo Paz, esta "é uma máquina [...]. Também é um esqueleto, um motor, um corpo oscilante no espaço, um inseto terrível, uma encarnação mecânica de Kali e uma alegoria da Assunção da Virgem ${ }^{335 " . ~ O ~ p a r ~ m e c a n i c i s m o-e r o t i s m o ~ e ́ ~ p a r t e ~ f u n d a m e n t a l ~ d a ~ o b r a . ~}$ A consolidação do erotismo nesta obra se dá pela premissa de que é a técnica, aqui negada, quem dará as condições para qualquer tipo de enlace sexual. Entre a Noiva e os Solteiros há uma distância que impossibilita o "abraço", o contato da carne, por fim, o erotismo humano. Paz cita, de passagem, uma monografia de Robert Lebel sobre

\footnotetext{
332 LEOPOLDO E SILVA, Franklin. Ibidem. p. 373.

${ }^{333}$ PAZ, Octavio. Ibidem. p. 30.

334 Ibidem. p. 32.

335 Ibidem. p. 33.
} 
Duchamp datada de 1959: "Lebel pensa que a quarta dimensão [física] designa o instante do abraço carnal durante o qual o par funde todas as realidades em uma - a dimensão erótica ${ }^{336 ”}$. Esta quarta dimensão seria a dimensão invisível entre os solteiros e a Noiva, realidade física em consonância com as cosmologias contemporâneas.

Portanto, onde quer que se dê o contato erótico nesta obra, ele certamente está num plano mental ou imaginário - abstrato - visto que é pressuposto para Duchamp que a sua obra partilhe de uma premissa platônica: a representação do quadro em duas dimensões já seria a cópia da cópia de um objeto de quatro dimensões. Se partilharmos da hipótese de Lebel, a de que a quarta dimensão, no interior desta obra, está vinculada à efetuação do enlace erótico, é certo afirmar que o contato existe. Mas, como ele se dá? Para Octavio Paz,

\footnotetext{
“a origem de todo esse movimento erótico-mecânico é um dos órgãos da Virgem: o Motor-Desejo. Duchamp sublinha que o Motor está "separado da Noiva por um esfriador de água". O esfriador "expressa que a Noiva, longe de ser um pedaço de gelo sem sensualidade, recusa calidamente (não castamente) o inopinado oferecimento de seus solteiros". Assim pois, entre a Noiva e os solteiros não há contato direto, mas à distância - um contato às vezes imaginário e outras, elétrico. Esta nova ambiguidade reflete, suponho, outra analogia verbal: o pensamento é elétrico e a matéria é pensamento ${ }^{337 "}$.
}

O desenho desta obra, $O$ Grande Vidro, é seu funcionamento. Por esta razão, Paz referese a ela como texto, talvez graças a seu caráter intelectual e anti-retiniano. Mas, assim como os textos míticos, sua estrutura é circular, ou seja, termina em seu princípio como a cobra que morde o próprio rabo. No caso desta obra, o ponto de convergência entre fim e começo é o Motor-Desejo. Neste universo erótico-mecânico, o Motor-Desejo figura como o primeiro-motor aristotélico (apesar do platonismo confesso por Duchamp), autossuficiente, pois não depende de terceiros. O momento do prazer, enfim, se dá quando "a operação termina quando a Noiva, por fim despida, experimenta

\footnotetext{
336 Ibidem. p. 34.

337 Ibidem. p. 36.
} 
uma tríplice sensação de distensão ou gozo: uma material [...], outra imaginária e uma terceira que engloba as duas primeiras, isto é, uma realidade erótico-mecânica e a mental ${ }^{338 "}$. Eis o momento de encarnação da obra, por mais paradoxal que pareça ser.

Ora, mas o que caracteriza esta obra como mito? Em primeiro lugar, não se trata apenas da estrutura circular do fluído erótico que percorre todo o maquinismo até aqui descrito, tampouco se resume ao fato de postular uma arché originária - o MotorDesejo. A caracterização desta obra como mito é possível, pois se trata de uma versão dialógica e atualizada de outro mito, a saber, a da deusa Kali e a da Virgem imaculada. A atualização do mito é e deve ser compreendida como, antes de mais nada, o contato de duas temporalidades distintas e, muitas vezes, conflitantes: a temporalidade histórica e a mítica. Nesta obra de Duchamp, o mecanismo, a técnica, é o produto histórico do Progresso e da teleologia linear em ritmo de marcha da modernidade, enquanto a estrutura circular e cíclica, que faz com que La mariée repita seus movimentos e instaure, a cada ciclo, um movimento erótico, atrativo, apesar de abstrato, é um resquício arquetípico de uma forma de significar e dar sentido pertencentes à racionalidade mitológica. Além disso, Paz reafirma o caráter mítico da obra diante de certa tendência, criticável segundo o autor, em diagnosticar psicologicamente boa parte das obras de arte modernas, a saber, restringindo-as a sintomas da esquizofrenia e do autismo. Acerca deste reducionismo, Paz argumenta que

\footnotetext{
“as realidades psicológicas e as da arte vivem em níveis distintos de significação: Freud nos oferece uma chave para entender Édipo, mas a tragédia grega não se reduz às explicações da Psicanálise. Lévi-Strauss diz que a interpretação de Freud é apenas outra versão do mito de Édipo: Freud nos conta, em termos correspondentes a uma época que substituiu a analogia mítica pelo pensamento lógico, o mesmo conto que Sófocles nos contou. Algo semelhante pode dizer-se do Grande Vidro; é uma versão do mito venerável da grande Deusa, a Virgem, a Mãe, a Exterminadora doadora de vida. Não é um mito moderno: é a versão moderna do mito ${ }^{339 " . ~}$
}

\footnotetext{
338 Ibidem.

339 Ibidem. p. 37.
} 
Semioticamente, é possível depreender que a obra de Duchamp se situa numa outra ordem de significação. Trata-se, pois, de um discurso de 2a ordem: é uma releitura do mito, não uma interpretação, tampouco uma análise, mas uma nova versão que se situa na mesma ordem de significação.

Para Roland Barthes, o mito é um discurso de segunda ordem, uma vez que nele podemos encontrar um esquema tridimensional, composto pelo significante, o significado e o signo. Contudo, o crítico francês adverte:

\footnotetext{
“o mito é um sistema particular, visto que ele se constrói a partir de uma cadeia semiológica que já existe antes dele: é um sistema semiológico segundo. O que é signo (isto é, a totalidade associativa de um conceito e de uma imagem) no primeiro sistema transforma-se num simples significante no segundo. [...]. Tudo se passa como se o mito deslocasse de um nível o sistema formal das primeiras significações. ${ }^{340}$
}

Enquanto, para Octavio Paz, podemos pensar que

\begin{abstract}
"no mito, [...] a linguagem articulada desempenha a mesma função que o sistema fonológico no discurso comum: o mito serve-se das palavras como nós, ao falarmos, nos servimos dos fonemas. Portanto, a linguagem do mito, a história contada com palavras, é uma estrutura inconsciente e pré-significativa sobre a qual se edifica o verdadeiro discurso mítico ${ }^{341 " .}$.
\end{abstract}

Marcel Duchamp torna a técnica a estrutura pré-significativa do seu mito em $O$ Grande Vidro, entretanto, não convém dizer que esta criação é inconsciente, pois é evocada pela consciência crítica. Em suma, podemos classificar este procedimento autoral como uma

\footnotetext{
340 BARTHES, Roland. Mitologias. Trad. Rita Buongermino e Pedro de Souza. 11a ed. - Rio de Janeiro: Bertrand Brasil, 2001. p. 205. (Edições nossas).

${ }^{341}$ PAZ, Octavio. Claude Lévi-Strauss ou o Novo Festim de Esopo. Trad. Sebastião Uchoa Leite. São Paulo, SP: Ed. Perspectiva, 1993. p. 34.
} 
tradução: Duchamp traduz o mito para a linguagem técnica e mecanizada que rege o nosso mundo moderno e este procedimento de tradução carrega no bojo a negação desta própria linguagem. No mais, sobre a tradução, Paz diz que o sentido do mito é sempre outro mito. Ao explicar como Lévi-Strauss interpreta o mito, o autor diz que:

\begin{abstract}
“[A] tradução é uma transmutação e daí que, como diz o seu autor, seja "um mito dos mitos americanos". Le cru et le cuit responde de certo modo à minha pergunta acerca do significado dos mitos: à maneira dos símbolos de Peirce, o sentido de um mito é outro mito. Cada mito desenvolve o seu sentido em outro que, por sua vez, alude a outro, e assim sucessivamente até que todas essas alusões e significados tecem um texto: um grupo ou família de mitos ${ }^{342 "}$.
\end{abstract}

Conforme veremos, este procedimento tradutório gera outro ciclo, outra estrutura circular que, na leitura de Octavio Paz, a caracterizará como um mito contemporâneo, ou seja, não se tratará apenas de uma versão atualizada, uma contemporaneização histórico de um mito antigo, mas o surgimento de um novo mito, através de sua tradução (ou transcriação). Paz diz:

\footnotetext{
"espero mostrar que o tema do Grande Mito é outro mito; quero dizer: o mito da Virgem e seus solteiros é a projeção ou tradução de outro mito. Por enquanto me limito a destacar a natureza circular da operação: o Motor-Desejo faz a Noiva sair de si mesma e esse desejoa encerra mais totalmente em seu próprio ser ${ }^{343 "}$.
}

Esta primeira explicação acerca do caráter circular da operação mecânico-erótica aponta para a circularidade da temporalidade do mito. Por conta disso, o mexicano fará a comparação do Grande Vidro a uma das divindades do hinduísmo: Kali (ou Cali). Esta deusa é a representação da natureza, sendo também uma manifestação de Shiva. Ao

\footnotetext{
${ }^{342}$ PAZ, Octavio. Claude Lévi-Strauss ou o Novo Festim de Esopo. Trad. Sebastião Uchoa Leite. São Paulo, SP: Ed. Perspectiva, 1993. p. 32.

${ }^{343}$ PAZ, Octavio. Ibidem. p. 40.
} 
compará-los, Paz diz que, para além da similaridade da separação entre a Noiva e o Motor e da ação que afasta Kali e sua cabeça,

“o mais notável é que em um e em outro caso assistimos à representação de uma operação circular que desvela a realidade fenomenal do mundo (que a põe a nu: a ex-põe) e simultaneamente the nega toda realidade de verdade. Esta coincidência não é externa, mas constitui a essência ou tema fundamental de ambas representações. As inegáveis semelhanças entre a imagem hindu e o Grande Vidro, a Caixa Verde e a explicação da tradição tântrica não implicam, naturalmente, relação direta entre elas. Tampouco é uma coincidência casual. São duas versões distintas e independentes de uma mesma ideia - talvez de um mito que se refere ao caráter cíclico do tempo ${ }^{344 \prime \prime}$.

Contudo, a grande fronteira entre ambas as estruturas míticas reside na racionalidade crítica. Em primeiro lugar, invés da representação da destruição e consequente criação do universo, como a relatada no mito cíclico Hindu, o mito duchampiano não traz, em si, um relato, não abarca uma estrutura narrativa, mas a trajetória de uma paixão que acomete a todos na modernidade. Máquina de significar, o Grande Vidro tem a sua importância, para Paz, pois figura como

\footnotetext{
"a última obra realmente significativa do Ocidente; e o é porque, ao assumir o significado tradicional da pintura, ausente na arte retiniana, dissolve-o em um processo circular e assim o afirma. Com ela termina nossa tradição. Ou seja: com ela e diante dela deverá começar a pintura do futuro, se é que a pintura tem um futuro ou o futuro há de ter pintura ${ }^{345 "}$.
}

Duchamp nega a Arte ${ }^{346}$ para fundar, talvez, a arte? Resposta nublada, Octavio Paz afirma ainda não saber se o futuro terá pinturas. Mas a afirmação ressoa também porque, para Paz, esta é a última obra significativa do ocidente, pois é a última imagem

\footnotetext{
344 Ibidem. p. 45.

345 Ibidem. p. 59.

${ }^{346}$ Institucionalidade, mercantilizada, hipostasiada, etc.
} 
erótica da virgem cristã no Ocidente, como relata em Conjunções e Disjunções. Entre Kali e Maria, entre a deusa e a Virgem, seus celibatários correspondem a seus adoradores:

\footnotetext{
"o quadro se divide em duas partes: na de cima a deusa, convertida num motor; na de baixo seus adoradores, suas vítimas e seus amantes - nem Acteo, nem Adonis ou Marte, mas nove fantoches uniformizados de policiais, porteiros de hotel e curas. O sêmen, a essência vital dos taoístas, transformado numa espécie de gasolina erótica, que se incendeia antes de tocar o corpo da Noiva. Do rito ao brinquedo elétrico: uma bufonaria infernal ${ }^{347 \prime \prime}$.
}

Octavio Paz, portanto, ainda aposta na crítica enquanto elemento intelectual capaz de figurar ao lado da atividade criativa. Como autor que se prostra na esteira dos movimentos romântico e surrealista, para não explicitarmos a influência da cultura hindu e indiana, o mexicano conserva a crítica graças à possibilidade que esta tem de negar, de estabelecer outro mundo, porém, sem se deixar levar pelo seu potencial mítico, à medida em que esta se mostrou capaz de construir edifícios metafísicos (e utópicos) onde não apenas a Técnica, mas a ideia de Progresso, escamotearam a realidade presente. Este é o motivo, aliás, de Paz encontrar nesta obra de Duchamp a crítica da crítica, isto é, a sua revelação em mito.

Para Paz, o mito duchampiano é sobre a construção de uma ideia ou de uma realidade sobre a qual nada se sabe: a quarta dimensão. A leitura de Paz, que coincide com a de Lebel, já nos indicou que esta quarta dimensão pode ser ocupada pelo jogo erótico da Noiva e seus solteiros, pois este jogo desemboca no enlace erótico. Contudo, Duchamp se cala e nos faz calar ${ }^{348}$. Diante da oposição negação/afirmação, "o silêncio de Duchamp [...] nos diz algo: não é uma afirmação (atitude metafísica) nem uma

\footnotetext{
347 PAZ, Octavio. Conjunções e Disjunções. Trad. Lucia Teixeira Wisnik. São Paulo: Perspectiva. 1979. p. 122.

${ }^{348}$ Paz cita uma carta de Duchamp endereçada a André Breton, onde o pintor diz ao poeta surrealista que "em termos de metafísica popular não aceito discussões sobre a existência de Deus, o que quer dizer que a palavra ateu, oposta a crente, nem sequer me interessa. [...] Para mim há outra coisa distinta do sim, do não ou do indiferente - por exemplo: ausência de investigação nesse domínio" (ibidem).
} 
negação (ateísmo) nem uma indiferença (agnosticismo cético). Sua versão do mito não é metafísica nem negativa, mas irônica: crítica $^{349 " .}$

Octavio Paz já nos disse que a crítica é uma das principais crenças da modernidade, a ponto de se ter estabelecido não como um princípio-motor de ideias, mas como uma paixão propriamente dita: apaixonada por si mesma e por seus poderosos mecanismos de desconstrução, a crítica é autodestrutiva. Cabe, então, questionar aqui: como se configuraria uma versão crítica do mito? A esta questão, Octavio Paz responde que,

\footnotetext{
"por um lado, é uma burla do mito tradicional: reduz o culto à Deusa, seja em sua forma religiosa ou na moderna, devoção à Virgem ou amor romântico, a um mecanismo grotesco em que o desejo se confunde com a combustão de um motor, o amor com a gasolina e o sêmen com a pólvora de artifício. Pelo outro lado, a crítica é também uma burla da concepção positivista do amor e, em geral, de tudo o que chamamos "modernidade" no sentido vulgar da expressão: "cientificismo", positivismo, tecnologia e tudo o mais. O Grande Vidro é uma pintura infernal e bufona do amor moderno ou, mais claramente, de tudo o que o homem moderno fez com o amor ${ }^{350 \prime \prime}$.
}

O Grande Vidro é uma obra que expressa o amor sem um de seus elementos mais significantes: a narrativa, o conflito e a disjunção que geralmente há entre um e o outro. Convertidos em símbolos técnicos, estéreis, está morto não apenas o erotismo, mas seu fundamento: o corpo. Ao anular o corpo, anula-se a experiência, anula-se a narrativa. $\mathrm{O}$ Grande Vidro é, em suma, um mecanismo técnico. Porém, como Paz demonstra em Conjunções e Disjunções, o corpo só é capaz de fundar um erotismo se ele se colocar no interior da correlação sagrado-profano. O esquema binário é pressuposto para todo tipo de significação do mesmo, inclusive quando pensamos a sua superação.

Neste sentido, o mito de Duchamp é crítico por impossibilitar que haja, aqui, uma adesão a qualquer âmbito do par-binário. Se por um lado a significação sagrado-religioso

\footnotetext{
349 Ibidem.

350 Ibidem.
} 
é esvaziado, não é necessário percorrer muito das obras de Duchamp para que compreendamos aquilo que o autor pensa acerca do progresso utilitarista. Diante da impossibilidade do culto às imagens prenhes de significação, o culto à técnica, ao progresso e à ciência, para o francês, seriam dignos de riso. Tanto neste ensaio, como em A Dupla Chama, como em Conjunções e Disjunções, Paz considera que o erotismo só se faz possível se o par sagrado-profano oferecer significação ao corpo, concedendo ou retirando sentido a suas ações. Em O Castelo da Pureza, acrescentará que

\footnotetext{
"o erotismo vive nas fronteiras do sagrado e do maldito. Ambas as categorias são inseparáveis: se o corpo é mero sexo e impulso animal, o erotismo se transforma em monótona função de reprodução; se a religião se separa do erotismo, tende a tornar-se árida preceptiva moral. Isto é o que ocorreu com o cristianismo, sobretudo em sua versão moderna, o protestantismo ${ }^{351 "}$.
}

A compreensão de Paz acerca da relação que o cristianismo protestante estabelece com o corpo foi esclarecida por nós anteriormente. Em resumo, ao considerá-lo mera preceptiva moral, o autor o coloca não apenas como uma religião que atingiu um ponto ascético e elevou a disjunção ao extremo, mas como uma doutrina diametralmente oposta ao tantrismo, que estabelece uma conjunção onde a identidade entre corpo e sagrado é assumida como princípio religioso. Ao negar a corporeidade do próprio corpo, o protestantismo acaba por negar-lhe a sua eternidade, pois, segundo Octavio Paz

\footnotetext{
“o corpo é imortal porque é mortal e nisto reside o segredo de seu permanente fascínio - o segredo da sexualidade quanto do erotismo. O elemento hilariante de $A$ Noiva... não consiste unicamente na operação circular de seu desejo, mas no fato de que Duchamp, em vez de pintar corpos radiantes e perecíveis, pintou máquinas opacas e rangentes ${ }^{352 "}$.
}

\footnotetext{
351 Ibidem. p. 46.

352 Ibidem.
} 
Máquinas animadas por sua funcionalidade, pela sua utilidade, jamais pelo desejo que atrai os corpos e lhes possibilita o contato.

Diante da pretensa intenção de vislumbrar nesta obra uma conjunção corpórea entre signos que ocupam lugares opostos, mas que se atraem na relação erótica, o intérprete se depara com o paradoxo: a Máquina-Desejo não deseja. A escolha de Duchamp em pintar máquinas, e não corpos, conduz sua obra à circularidade:

\footnotetext{
“em suma, a crítica de Duchamp é dupla: crítica do mito e crítica da crítica. [...] No primeiro momento, traduz os elementos míticos em elementos mecânicos e assim os nega; no segundo, translada os elementos mecânicos a um contexto mítico e os nega por sua vez. Nega ao mito com a crítica e à crítica com o mito. Esta dupla negação produz uma afirmação nunca definitiva, em perpétuo equilíbrio sobre o vazio ${ }^{353 \prime \prime}$.
}

Perpétuo equilíbrio ou perpétuo retorno? O movimento crítico de Duchamp é circular, pois, assim como a crítica apaixonada por si mesma, não consegue estabelecer uma série de ideias, de pensamentos ou qualquer linearidade narrativa. A cobra que engole o próprio rabo é compreendida como uma imagem do tempo que se déstrói a si mesma para poder principiar. No caso da crítica, esta destruição vem acompanhada da total aniquilação do sentido, inclusive da própria negação. Contudo, ao nos distanciar dela, através dela mesma mesma, Duchamp possibilita que a enxerguemos como o Mito em que ela se transformou. Levanta-se, então, a questão: uma vez que a própria crítica, enquanto ferramenta da razão, se transformou num mito ou numa ferramenta capaz de erigir mitos perniciosos (e podemos pensar, aqui, por exemplo, os do fascismo, do Progresso e do cientificismo), o que ainda pode a crítica? O que ainda pode a razão?

Pensando no universo onírico, capaz de confabular realidades críticas e resgatar mundos soterrados pelo ramerrão da memória seletiva, Walter Benjamin escreve nas Passagens sobre a relação entre razão e mito que nós

353 Ibidem. 
“[Devemos] tornar cultiváveis regiões onde até agora viceja apenas a loucura. Avançar com o machado afiado da razão, sem olhar nem para a direita nem para a esquerda, para não sucumbir ao horror que acena das profundezas da selva. Todo solo deve alguma vez ter sido revolvido pela razão, carpido do matagal do desvario e do mito ${ }^{354 \prime}$.

Se o mito é capaz de abarcar as imagens que correspondem a potencias perigosas à humanidade, como as que Benjamin classifica como "desvario", não cabe senão à crítica manter o seu papel analítico do rigor, da ponderação, no sentido que a tradição lhe conferiu: deve ser ferramenta de desconstrução precisa. Contudo, o próprio Benjamin se manteve atento aos momentos em que a razão outorgou a realidade histórica oficial como válida. Diante desta disputa narrativa, o pensamento materialista-histórico, na visão do alemão, deveria possibilitar que as ideias críticas pudessem encontrar sua origem no universo suplantado pelo universo informacional que subtrai do corpo da história séries de memórias, narrativas e fatos subjugados por poderes despóticos. 0 machado da razão - em que pese a metáfora de um instrumento que hoje se alinha a uma ideia de progresso (ainda que machados sejam totalmente distintos de motosserras, do ponto de vista da crítica à técnica já apresentada por Heidegger) - deve se fazer presente na urgência do despertar, ou seja, a crítica, ainda que se valha do mito para fazer crítica a si mesma, não pode abrir mão de seu papel originário. Da mesma forma, para Octavio Paz, a tradição poética moderna deve permanecer crítica.

Ao apontar o mito da crítica, Duchamp levanta a questão: a associação de crítica e racionalidade ao progresso técnico da máquina nos leva a um caos mitológico? Cabe, então, resgatar a crítica de seu próprio desvario, através da própria crítica, agora voltada sobre si mesma de uma forma distanciada. N'O Grande Vidro é possível perceber que Marcel Duchamp modificou a crítica, mas se valeu de outro regime discursivo para evidenciá-la como problema da linguagem. Por isso, Octavio Paz afirma:

\footnotetext{
354 BENJAMIN, Walter. Passagens. Org. e Trad. Willi Bolle. São Paulo: Imprensa Oficial/UFMG, 2009. p.
} 499. 
"sublinho que também e sobretudo é o Mito da Crítica: a pintura da única ideia moderna. Mito crítico: crítica do mito religioso e erótico da Noiva Virgem em termos do mecanismo moderno e, simultaneamente, mito burlesco de nossa ideia da ciência e da técnica ${ }^{355 ”}$.

Ou seja, ainda que a linguagem d'O Grande Vidro, graças à ironia presente na obra, seja essencialmente negativa, o seu aspecto crítico recai sobre a "Ideia" moderna de crítica, pois é esta que desemboca na racionalidade técnica.

Podemos afirmar, portanto, que é nesta ambiguidade existente entre mito e crítica que $O$ Grande Vidro aparece como uma obra elementar dentre aquelas que apontam o encerrar de um ciclo, o esgotamento de uma temporalidade, pois, a partir de sua incapacidade de fundar uma analogia, de estabelecer uma correspondência entre as coisas no mundo, a negatividade da obra faz refluir o sentido, uma vez que se volta sobre si mesma e, como no movimento dialético, resulta numa afirmação: a restituição da analogia num mundo demarcado pela ironia em todas as esferas. Octavio Paz diz: "A

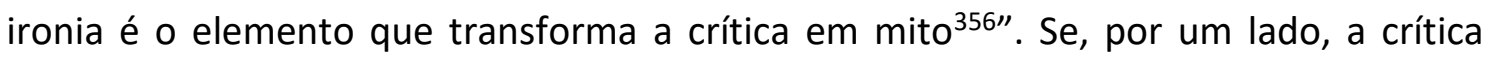
objetiva já apareceu no interior de outras obras como o elemento que apontava esse esgotamento arquetípico, o aparecimento do mito supre a operação desejada pela própria crítica, em seu afã de negação, estabelecendo uma racionalidade contrastante, que nos permitiu coloca-la em perspectiva, junto com todos os elementos e instrumentos da racionalidade moderna: a técnica, a ciência, o Estado e o progresso. Por isso, para Octavio Paz,

\footnotetext{
"o Grande Vidro "é um quadro que faz pensar em certas obras que anunciam e revelam o mundo moderno, sua oscilação entre mito e crítica. Penso na epopeia burlesca de Ariosto e no Quixote, que é uma novela épica e uma crítica da épica. Com estas criações nasce a ironia moderna; com Duchamp e outros poetas do século $\mathrm{XX}$, como Joyce e Kafka, a ironia se volta contra si mesma. $\mathrm{O}$
}

355 PAZ, Octavio. Ibidem. p. 50.

356 Ibidem. 
círculo se fecha: fim de uma época e começo de outra. O Grande Vidro está na fronteira de um e outro mundo, o da "modernidade" que agoniza e o novo que começa e que ainda não tem forma ${ }^{357 " \prime . ~}$

Portanto, ao inserir a Crítica no ritual de circularidade, Duchamp a transforma em mito e, com isso, propicia o encerramento do ciclo da modernidade. Porém, como em todo mito originário, sua destruição é criadora.

Ora, quando Paz fricciona os termos contrários na relação mito-crítica, quando se vale da Coincidentia Oppositorum para estabelecer este par, não é óbvia a intenção de fazer mover o processo dialético em que, necessariamente, haveria a superação da contradição na direção de uma síntese. A afirmação, resultante da negação entre dois termos, no caso em que pensamos aqui, entre Crítica e Mito, não pode ser absoluta, mas apenas provisória. Tanto é assim que, para o autor, mais importante do que forçar a superação entre os dois contrários é fazer, à maneira da poesia, com que estas cooperem no interior do mesmo pensamento: voltamos à coabitação do contraditório. Se há um processo dialético na obra de Duchamp, este só pode surtir efeito graças à "ironia de afirmação" que visa a minar a autoridade da razão - autoridade que, como já apontamos, se consolidou como hipóstase no interior do processo histórico da modernidade. Entretanto, Paz adverte: Duchamp "não é um irracionalista: aplica à razão uma crítica racional: o humor delirante e raciocinado é o disparo pela culatra da razão. Duchamp é o criador do Mito da Crítica, não um professor que faz a crítica do mito ${ }^{358 " .}$

Por esta razão, Octavio Paz comparará a obra de Marcel Duchamp à de Stéphane Mallarmé: o Grande Vidro e Un coup de dés jamais n'abolira le hasard são obras cujo conteúdo é intelectual e cuja resposta para os oxímoros presentes na mesma é sempre provisória e, por este mesmo motivo, livres. Neste sentido, a pintura de Duchamp não seria retiniana e o poema de Mallarmé não seria apenas uma proposição de imagens, mas uma estrutura condicional, que aponta saídas diversas (ou a ausência das mesmas) a partir da primeira sílaba que se enuncia neste poema: "Se", a partícula sugestiva da condicionalidade. Duchamp está para Mallarmé no mesmo sentido em que a ironia está

\footnotetext{
357 Ibidem. p. 51.

358 Ibidem. p. 63.
} 
para o acaso. Esta correlação se reforça no fato de que tanto uma quanto a outra são "obras abertas":

"o inacabamento do Grande Vidro é semelhante à palavra última, que nunca é a do fim, de Un coup de dés: é um espaço aberto que provoca novas interpretações e que evoca, em seu inacabamento, o vazio em que se apoia a obra. Este vazio é a ausência da Ideia. [...] Metáforas do vazio ${ }^{359 . "}$

O último verso do poema de Mallarmé é "Tout Pensée émet un Coup de Dés". Se todo pensamento emite um lance de dados, isto é, se se lança a um universo cambiável de imagens e ideias possíveis, antes de lá chegar, passamos pelo vazio: o da ideia que está em vias de se constituir. No caso, o vazio da ideia pode ser compreendido aqui para além do esfacelamento dos princípios imperativos de Progresso, Técnica e Ciência, pois o símbolo do esgotamento é o da imagem teleológico-linear da temporalidade. O vazio que Paz ressalta é, por sua vez, um vazio da imagem de tempo que vigorou sobre a sociedade ocidental na segunda metade do século XX e está, mediante a série de acontecimentos vividos nesta fase, se esgotando, nublando.

Podemos considerar que a afirmação provisória, estabelecida ao final do poema, bem como a observação da pintura inacabada possibilita, em cada caso, uma nova leitura. Em cada uma destas leituras, é possível estabelecer o que Paz chama de "constelação", ideia possibilitada pela disposição tipográfica dos elementos na folha em branco como pelo espírito "em branco" da época, o "vazio" a que alude Octavio Paz. Em suma, para o autor,

\footnotetext{
“o poema e a pintura afirmam simultaneamente a ausência de significado e a necessidade de significar e nisto reside a significação de ambas as obras. Se o universo é uma linguagem, Mallarmé e Duchamp nos revelam o reverso da
}

359 Ibidem. p. 54. 
linguagem: o outro lado, a face vazia do universo. São obras em busca de significação ${ }^{360 \prime \prime}$.

O Grande Vidro de Marcel Duchamp, Primero Sueño de Sor Juana Inés de la Cruz e Un coup de dés de Mallarmé, apesar de seu distanciamento histórico, são obras que se inserem, em sua abertura, numa poética da busca que, na visão de Paz, não pode ser senão a da procura do sentido. Sentido que é compreensível se tivermos êxito no confronto e no diálogo com o tempo. Por isso, o autor conclui:

\footnotetext{
"nisto reside o segredo do fascínio do Grande Vidro e dos ready-made: um e outros reclamam uma contemplação ativa, uma participação criadora. [...] Duchamp está contra o Museu, não contra a Catedral; contra a coleção, não contra a arte fundida à vida, [que quer dizer] poema de Mallarmé ou romance de Joyce: a arte mais difícil. Uma arte que obriga o espectador e o leitor a converter-se em um artista e em um poeta ${ }^{361 "}$.
}

A ideia de crítica, para Paz, deverá ser acompanhada do gesto de revolta que acompanha o presente. É por esta razão que Paz possibilita, em sua obra, que o par imaginaçãocrítica sobreviva sem que um extremo anule o outro, ou seja, em cooperação, pois, menos do que uma crítica da crítica, a escolha de Duchamp revela não um abandono da crítica, mas uma exortação da mesma, porém, uma crítica que deve ser, primordialmente, imaginativa.

Se podemos pensar que o método analógico do autor é o de quem constrói seu pensamento através de uma conjunção entre razão e imaginação, isto é, da imagemconceito, devemos expor que Paz também encontrou na ciência de sua época um correlato de seu modo de pensar poético (este modo de pensar que possibilita aos contrários uma convergência, como ficou explícito em Conjunções e Disjunções). 0 cientista que será o modelo epistemológico de Paz será o antropólogo: já na citação

\footnotetext{
360 Ibidem. p. 55.

361 Ibidem. p. 61.
} 
acima, podemos reconhecer que o seu modelo de fruição estética não é senão o da observação participativa: "As Testemunhas Oculistas são parte do Grande Vidro; o espectador da Conjugação, pelo fato mesmo de espreitar participa no rito dual do voyeurismo e da contemplação estética. Sem ele, não se cumpriria o rito ${ }^{362 "}$. Por esta razão, o leitor passivo - distanciado de seu objeto, mero contemplador - é o extremo oposto da conjunção que complementa o poeta e que, para Paz, é necessário. O poeta vai além e para que possamos compreendê-lo, devemos compreender como se deu a sua leitura acerca do antropólogo em questão. Trata-se do estruturalista Claude LéviStrauss.

362 Ibidem. p. 87. 


\section{Claude Lévi-Strauss e a consolidação do pensamento analógico}

Para falarmos do antropólogo francês, devemos principiar pela mesma questão que fizemos acerca de Duchamp. Por que Claude Lévi-Strauss? Octavio Paz, em seu ensaio Claude Lévi-Strauss ou o Novo Festim de Esopo inicia seu texto justificando sua escolha e se isentando, de uma maneira que poderíamos chamar "socrática", uma vez que irônica, de não oferecer uma interpretação rigorosa do ponto de vista científico. Similarmente à sua postura em O Labirinto da Solidão, Paz, mesmo reconhecido como o notório ensaísta que era e tendo já publicado diversos textos escritos em razão argumentativa, sempre faz questão de lembrar o seu local de poeta. Por isso, diz Paz:

\footnotetext{
“Já disse antes que os meus comentários não são de ordem estritamente científica; examino as ideias de Lévi-Strauss com a curiosidade, a paixão e a inquietude de um leitor que deseja compreendê-las porque sabe que, como todas as grandes hipóteses da ciência, estão destinadas a modificar nossa imagem do mundo e do homem ${ }^{363 \prime \prime}$.
}

Imagem de mundo que é correlata à imagem de tempo, uma vez que entre ambas não há dissociação. O que Paz extrai de Lévi-Strauss? A constatação de que o mundo opera por relações, as quais, por sua vez, são binárias. Já apresentamos que, para Paz, este princípio atende à lógica da coicidentia oppositorum. Para o poeta, o pensamento binário "é um crivo que orienta e distribui o fluir das gerações. Cumpre assim uma função de alteridade e mediação - diferenciar, selecionar e combinar - que converte as uniões sexuais em um sistema de significações ${ }^{364 "}$. Em suma, este sistema binário é um artifício "pelo qual e no qual se cumpre o trânsito da natureza à cultura ${ }^{365 ", ~ a t r a v e ́ s ~ d o ~}$ tabu do incesto, talvez um dos conceitos mais importantes de Claude Lévi-Strauss.

Tamanha importância possui esta questão que, para Paz, a resposta de LéviStrauss ao tabu do incesto levanta questões filosóficas similares àquelas que tocam a

\footnotetext{
363 PAZ, Octavio. Claude Lévi-Strauss ou o Novo Festim de Esopo. Trad. Sebastião Uchoa Leite. São Paulo, SP: Ed. Perspectiva, 1993. p. 10.

${ }^{364}$ Ibidem. p. 18.

$365 \mathrm{Ibidem}$.
} 
linguagem e o fundamento último de todo dizer, uma vez que se voltam às atividades que estão na imanência da nossa vida e da nossa constituição humana. Ao nos perguntarmos sobre algo tão constituinte, perguntamos sobre algo que possibilita que estejamos realizando o simples ato de perguntar:

\footnotetext{
"que significa este tabu que nada nem ninguém explica e que, embora pareça não ter justificação biológica nem razão de ser, é a raiz de toda proibição? Qual o fundamento deste Não universal? É verdade que este Não contém um Sim: a proibição não apenas separa a sexualidade animal da sexualidade animal mas, como na linguagem, este Sim funda o homem, constitui a sociedade. A proibição do incesto nos faz defrontar, noutro plano, com o próprio enigma da linguagem: se a linguagem nos funda, nos dá sentido, qual é o sentido deste sentido? A linguagem nos dá a possibilidade de dizer, mas que quer dizer dizer ${ }^{366}$ ?"
}

O mesmo poderia ser questionado acerca do tempo: o tempo é o que constitui o homem, mas o que é tempo? Certo, Agostinho já não deparara com esta questão ao dizer que é fácil mencioná-lo, difícil é defini-lo, porém, ainda assim a relação entre a imagem de tempo e o rumo de uma sociedade não era tão evidente.

Ora, os seres humanos não têm consciência do que é o canal por onde perpassa o mito, assim como não tem consciência do nome do tempo em que vivem. Apenas desconhecemos, apesar de reproduzirmos o mito, proferirmos as palavras poéticas ou, igualmente, refletirmos em nossas ações, pensamentos e desejos a imagem de tempo que rege nossa sociedade. Isto se explica porque tanto a construção do mito quanto a construção da imagem de tempo são fatos coletivos, cuja premissa é sua ocorrência no interior de um processo histórico:

\footnotetext{
“o grupo social que elabora o mito, ignora o seu significado; aquele que conta um mito não sabe o que diz, repete o fragmento de um discurso, recita uma
}

\footnotetext{
366 Ibidem. p. 20.
} 
estrofe de um poema cujo princípio, fim e tema desconhece. O mesmo ocorre com os seus ouvintes e com os ouvintes de outros mitos ${ }^{367 ”}$.

"Os homens nunca conseguiram nomear o tempo que viveram e nós não somos uma exceção a esta regra universal ${ }^{368 "}$, diz Paz em A Outra Voz. Contudo, nomeamos o mito, apenas não sabemos que a ele estamos arraigados e que, ao traduzi-lo, colocámo-lo em processo histórico. Qualquer processo de distanciamento é lento e gradual.

Por isso, o trabalho do antropólogo é, para Lévi-Strauss, através de sua traduzibilidade em termos universais, conectar as muitas versões de um mesmo mito ou de uma mesma estrutura pré-significativa que o embasa. Desta forma, o resultado do trabalho antropológico deverá ser a constituição de um sistema de vasos comunicantes, onde cada mito opere sentido no interior de outro e onde os sistemas de equivalências e contradições se reconheçam nos gestos desempenhados por outra cultura que possui seu relato correspondente. De certo,

\footnotetext{
"ninguém sabe que esse relato é parte de um imenso poema: os mitos se comunicam entre si por meio dos homens e sem que estes o saibam. Ideia não muito distanciada da dos românticos alemães e dos surrealistas: não é o poeta que se serve da linguagem e sim esta que fala através do poeta. Há uma diferença: o poeta tem consciência de ser um instrumento da linguagem e não estou muito certo de que o homem do mito saiba que o é da mitologia ${ }^{369 \prime \prime}$.
}

No mito, a linguagem articulada opera de uma forma similar ao sistema fonológico no discurso comum. Como já afirmamos anteriormente, a linguagem opera no interior do mito da mesma forma que o sistema fonológico sustenta a linguagem comum. Esta gramática, que possui uma série de variações, para além de nos mostrar um sistema cuja racionalidade foi, durante muitos anos, ofuscada pelo padrão de racionalidade

\footnotetext{
367 Ibidem. p. 33.

368 PAZ, Octavio. La otra voz. Obras Completas, vol. I: La casa de la presencia. Ciudad de México: Fondo de Cultura Económica, 2003. p. 515. [tradução nossa].

369 PAZ, Octavio. Claude Lévi-Strauss ou o Novo Festim de Esopo. Trad. Sebastião Uchoa Leite. São Paulo, SP: Ed. Perspectiva, 1993. p. 33.
} 
eurocêntrico, demonstra, para Lévi-Strauss, a confirmação de uma hipótese ainda mais ousada: a da universalidade da própria razão no seio da natureza humana. Para Paz, "a universalidade da razão - uma razão maior que a razão crítica - ficaria demonstrada pela ação do pensamento que ainda há pouco chamamos de irracional ou pré-lógico ${ }^{370 " .}$

Esta razão - simbólica, alegórica, "irracional”, mágica, "selvagem - consiste numa estrutura atemporal que resolve as muitas particularidades da história e da sociologia. A força universalizante do argumento de Lévi-Strauss possibilita que Paz explore as conexões que outrora apresentamos: Kali e a Virgem; Maria e Tonantzin; Hernán Cortés e Quetzalcoatl; a pirâmide asteca e Partido Revolucionário Institucional, etc. No mais, estas correlações são intuitivas à própria poesia, sobre quem Octavio Paz diria que já possui, em sua própria natureza, a possibilidade de estabelecer analogias não apenas entre coisas distintas ou mesmo opostas, mas entre figuras arcaicas de culturas diferentes. Ademais, podemos afirmar que o contato de Paz com o estruturalismo, junto de sua descoberta da linguística jakobsoniana, gerou um repovoamento conceitual e teórico a uma obra já enriquecida pelas contribuições surrealistas e da mística oriental ${ }^{371}$. Este contato gerou novas diretrizes e, por assim, dizer, aperfeiçoou o método paziano.

Ao nos elucidar a respeito de uma característica humana, presente em todas as culturas, que põe por terra qualquer pretensão de hierarquização entre elas, somos instruídos por uma compreensão mais ampla acerca da ausência de centro no mundo. Não que Paz afirme uma relativização deste, mas sim uma visão ideogramática do mundo de forma que cada cultura dê a sua interpretação de um mesmo mito e o reconte à sua maneira. Novamente, a ideia de história universal se fragiliza:

\footnotetext{
“às pretensões da história universal, que inutilmente tenta reduzir a pluralidade das civilizações a uma só direção ideal - ontem encarnada na Providência e hoje desencarnada na ideia do progresso - [Lévi-strauss] opõe uma visão vivificante: não há povos marginais e a pluralidade das culturas é
}

\footnotetext{
370 Ibidem. p. 36.

${ }^{371}$ MACIEL, Maria Esther. Voo transverso: Poesia, Modernidade e Fim do Século XX. Rio de Janeiro: Sete Letras, 1999. p. 121.
} 
ilusória porque é uma pluralidade de metáforas que dizem a mesma coisa ${ }^{372 "}$ (negrito nosso).

Nesse sentido, então, mesmo as imagens e conceitos da cultura ocidental encontrariam o seu correlato em outras culturas radicalmente diferentes. O próprio fazer poético possui uma relação estreita com o mito.

Paz afirma que a similaridade entre poesia e mito se dá no fato de ambas presentificarem o tempo. Isto porque, como está posto em O Arco e a Lira, nem todos os mitos são poemas, mas todos os poemas são mitos ${ }^{373}$. A razão para isto se deve à forma como ambos os gêneros discursivos se atualizam no momento em que são evocados: o mito durante o rito e a poesia, por sua vez, durante a leitura. Esta atualização, por ser uma afirmação do tempo originário da poesia e do mito, é também uma negação da temporalidade corriqueira, linear e sucessiva. Poesia e mito são presentificadores do tempo e o entendem como gestação:

\footnotetext{
“o tempo do poema é cronométrico e, do mesmo modo, é outro tempo que é a negação da sucessão. Na vida diária dizemos: o que passou, passou; mas no poema aquilo que passou regressa e encarna outra vez. O poeta, diz o centauro Quiron a Fausto, não está encadeado no tempo: fora do tempo Aquiles encontrou Helena. Fora do tempo? Melhor dizer, no tempo original... inclusive nos poemas épicos e nas novelas históricas o tempo da narrativa escapa à sucessão. $O$ passado e o presente dos poetas não são os da história e os do periodismo; não são aquilo que foi nem aquilo que passa, mas o que está sendo, o que se está fazendo. Gesta, gestação: um tempo que se reencarna e se reengendra ${ }^{374 \prime}$.
}

O tempo compreendido como gestação é o tempo que possui um processo vital, cujo pressuposto é a nossa compreensão acerca de nossa própria mortalidade. O tempo que

\footnotetext{
372 Ibidem. p. 37.

${ }^{373}$ PAZ, Octavio. O arco e a lira. Trad. Ari Roitman e Paulina Wacht. São Paulo: Cosac Naify, 2012. p. 64.

374 PAZ, Octavio. Claude Lévi-Strauss ou o Novo Festim de Esopo. Trad. Sebastião Uchoa Leite. São Paulo, SP: Ed. Perspectiva, 1993. p. 47.
} 
se gesta é o que participa de um processo de elaboração, no caso, a de um processo vital, de um entremeio, que se partilha do nascimento à morte. Segundo Benedito Nunes, o tempo está intimamente ligado à nossa condição originária. Em termos heideggerianos, o filósofo brasileiro explica que

\footnotetext{
"se o Dasein é poder-ser e se a morte é o horizonte negativo dessa possibilidade, que a totaliza pondo-lhe termo, então a existência é sempre movimento extático, ou seja, um sair de si mesma (futuro), que volta a si, à situação fáctica em que se encontra (passado) e imerge no meio dos entes com os quais se defronta (presente). Correlação recíproca entre as três dimensões - futuro, passado e presente, enquanto êxtases do Dasein -, a temporalidade, sentido do ser desse ente, é nossa condição própria. Ser humano é ser temporal. Por isso, a temporalidade não é só condição de possibilidade de representar as várias modalidades de tempo, como também a possibilidade da compreensão do ser $^{375 "}$.
}

O Dasein, compreendido como Ser-aí, é o que mais se aproxima da ideia de gestação, pois ela envolve o Cuidado, no sentido da essência da existência, em sua radicalidade pura, pois, em primeira instância, há uma disposição do Ser como existência e, uma vez compreendida na sua extensão, há a sua compreensão no cuidado. Projetar-se no cuidado é se assenhorar do Destino que se descortina diante do mar de possibilidades abertas. Por isso, similarmente, Paz diz: "sentir-se e saber mortal é ser diferente: a morte nos condena à cultura. Sem ela não haveria artes nem ofícios: linguagem [é mediação] entre a vida imortal da natureza e a brevidade da existência humana ${ }^{376 " .}$. Contudo, este mesmo cuidado possui uma dimensão histórica, pois é nela que o ser humano, finito entre os limites de seu nascimento e sua morte, projeta-se:

\footnotetext{
“temporalidade significa igualmente o caráter histórico do Dasein, o acontecer de sua existência, embrionário no futuro e passado persistindo no presente. Daí a finitude do homem, mortal e sem fundamento último, metafísico ou
}

\footnotetext{
375 NUNES, Benedito. Crivo de Papel. São Paulo: Ed. Ática, 1998. p. 92.

${ }^{376}$ PAZ, Octavio. Ibidem. p. 42.
} 
teológico. Finito é ainda o estado de congênita incompletude do conhecimento humano; a autonomia do sujeito cognoscente funda-se numa atitude derivada do compreender, temporal e histórico. Dependendo da abertura que a ele se antecipa e da temporalidade que o limita, o conhecimento teórico não é infinito ${ }^{377 \prime \prime}$.

O projetar-se no cuidado é um ato que realizamos na história, pois somos, por outro lado, seres culturais e, nesse âmbito, a manifestação cultural é aquela que, como mostra Paz, revela resistência à tessitura do tempo e se projeta como eternidade. O próprio mito, enquanto marca de uma construção temporal, se projeta à eternidade, ainda que Ihe pese o traço marcadamente histórico. Esta temporalidade se manifesta no rito, mas, através de suas imagens dialéticas, resiste ao próprio tempo histórico retilíneo e linear, produzindo o fenômeno do tempo plural nas mais diversas culturas - sobretudo, aquelas que passaram por períodos de colonização, como o próprio México e a Índia.

Se a relação das artes temporais com o tempo é dialógica, podemos dizer que estas o afirmam somente para negá-lo. No interior da sincronia que estabelecem, tornam discerníveis séries diacrônicas que não seriam perceptíveis sem o desvelamento dos fatos cuidadosamente selecionados. Isto é, "são diacrônicos e sincrônicos: o mito conta uma história e, como o concerto, se desenvolve no tempo irreversível da audição; o mito se repete, se reengendra, é tempo que volve sobre si mesmo ${ }^{378 "}$. Ao sentirmos a vibração da música, como que partilhamos de seu ritmo e anulamos o transcorrer, como se partilhássemos, neste instante, de certa parcela de eternidade. O mesmo se passa quando somos imersos no tecido narrativo do mito: ao partilharmos dos eventos que retornam, através do tempo cíclico. Ademais, sobre este tempo, Octavio Paz afirma que

\footnotetext{
“a visão do tempo cíclico engloba o acontecer histórico como uma estrofe subordinada do poema circular que é o cosmos. É um compromisso entre o sistema atemporal dos primitivos e a concepção de uma história sucessiva e irrepetível. [...] A américa Central não teve história mas mitos e, sobretudo, ritos. A queda de Tula, a penetração tolteca em Yucatán, o desaparecimento
}

\footnotetext{
377 NUNES, Benedito. Ibidem.

378 PAZ, Octavio. Ibidem. p. 46.
} 
das grandes teocracias e as guerras e peregrinações dos astecas foram acontecimentos transformados em ritos e vividos como ritos. Não se entenderá a conquista do México pelos espanhóis se não se contempla como viram e viveram os astecas: como um grandioso rito final ${ }^{379 "}$.

Ou seja, sem a compreensão do conflito das temporalidades no interior do processo de colonização do México, onde do choque entre a cultura asteca - e seu ritmo circular contra a cultura espanhola - e seu ritmo linear e sucessivo - brotou uma visão híbrida, bem como uma cultura híbrida, não é possível entender como se coadunou um processo de dominação política, embrenhada pela técnica e superioridade militar dos espanhóis, à visão de um fim de ciclo, fim dos tempos, na compreensão de tempo circular dos astecas.

A Índia possui um hibridismo similar ao do México. Por estas razões, Paz abusa das comparações. Para ele, desde o princípio

\footnotetext{
“a Índia se propôs abolir a história pela crítica do tempo, e a pluralidade de sociedades e comunidades históricas pelo regime de castas. [...] Budismo e brahamanismo negam a história. Para os dois a mudança, longe de ser uma manifestação positiva da energia, é o reino ilusório da impermanência. [...] A crítica do tempo e o regime de castas são os dois pólos complementares e antagônicos do sistema indiano. Por meio de ambos a Índia se propõe a abolição da história ${ }^{380 \prime \prime}$
}

Entretanto, o resultado foi, como já apontamos, uma convivência híbrida, não desprovida de conflitos, entre ambas as temporalidades, à medida em que a sociedade indiana, como a latino-americana, foi adentrando o universo capitalista, absorvendo

\footnotetext{
379 Ibidem. p. 67.

380 Ibidem. p. 68.
} 
todos os seus pressupostos, desde a divisão social do trabalho, até a fetichização das mercadorias e o desenvolvimento da sociedade de consumo.

Porém, o mito subsiste. Muitas vezes, deformado, ocultado, ou transformado em outra coisa. E, nesse âmbito, a decifração estrutural do mito é uma operação similar à poética. Para Lévi-Strauss, a função poética da linguagem contém como sua parte integrante o mito. Estes são, segundo Paz,

\footnotetext{
“objetos verbais que utilizam, portanto, uma clave linguística; esta primeira clave (que implica dois níveis: o fonológico e o significativo ou semântico) serve ao pensamento mítico para elaborar uma segunda clave; por sua vez, Le cru et le cuit oferece uma terceira clave que permite traduzir a "lógica concreta" do mito em um sistema de símbolos e proposições lógicas. Esta tradução é uma transmutação e tem mais de uma semelhança com a tradução poética, tal como Valery a definiu: com meios diferentes produzir efeitos ou resultados semelhantes ${ }^{381 "}$.
}

Podemos afirmar, a partir desta passagem, que a ideia de tradução para Paz é similar à transcrição. Por conta disso, cabe pensar, também, o papel de Paz como decifrador de mitos e como seu discurso - alocado numa terceira ordem - se coloca de forma similar ao de Lévi-Strauss, uma vez que entre o mitólogo e o poeta há uma conexão mínima. Já se pode adiantar que, nas palavras do mexicano, "em ambos os casos a tradução é transmutação e em ambos não abandonamos a esfera da linguagem [...]. Mitos e equações se traduzem como os poemas: cada tradução é uma transformação ${ }^{382 " . ~ E s t a ~}$ transmutação só se torna possível pois os mitos - como apontam as conclusões de LéviStrauss -, os poemas e os símbolos lógico-matemáticos operam como sistemas de equivalências, arbitrários no interior de cada cultura. Sistemas cuja variabilidade e posicionamentos dos signos poderá se modificar historicamente, mas cujas estruturas tenderão a se revelar a marca de uma possível nova leitura acerca da natureza humana.

\footnotetext{
381 Ibidem. p. 55.

382 Ibidem. p. 56.
} 
Além disso, os mitos operam de forma participativa na poesia e na filosofia, distinguindo-se delas, pois assumem a posição de metalinguagem e de função poética, assim como sua posterior interpretação pelo mitólogo. Paz dirá que

\footnotetext{
“o livro de Lévi-Strauss é uma metalinguagem e, ao mesmo tempo, um mito de mitos; pela primeira, serve-se dos mitemas para construir proposições que são, de certo modo, equações; pela segunda, participa da função poética, pois se serve das equações para elaborar sequências ${ }^{383 \prime \prime}$.
}

Ora, Paz dirá que cabe ao poeta buscar estabelecer sequências no interior de seu poema, bem como equivalências ou antonímias, seja pela estrutura sonora (rimas, metro, acentos, aliterações, assonâncias, etc), seja pelo semântico (metáforas e metonímias). Ao considerar que Lévi-Strauss estabelece tais sequências, no sentido de criar razoabilidade e compreensibilidade em seu discurso científico, o antropólogo aproxima-se, talvez à sua própria revelia, do poeta. Ao tomar Le cru et le cuit como um livro que é "mito de mitos americanos" ou, como o próprio mexicano afirma, um "poema", Paz insere a obra de Lévi-Strauss nas referências que alteraram o espírito sensível de sua época e que também lhe servem de modelo epistemológico, ao qual aderirá parcialmente, uma vez que seu repertório contém uma polifonia de influências, por vezes, contraditórias entre si, mas coerentes em seu pensamento.

Apesar de considerar que o antropólogo possui uma capacidade de elaboração extremamente criativa e interpretativa, visível nas séries e sequências, dos signos matemáticos presentes nas equações que traduzem os sistemas de relações e equivalências, o poeta considera que Lévi-Strauss ainda conserva (para usarmos uma expressão de José Gaos) a "soberba” mal humorada do filósofo, para quem importa mais a visão total do universo - contraditoriamente, seu cárcere, isto é, seu impulso à universalização. Contudo, Le cru et le cuit pode ser lido, segundo Paz, como um poema. Não por menos, esta obra figuraria ao lado de Ulysses, $A$ la recherche du temps perdu, Um coup de dés e Soledades. Obras poético-literárias cuja inventividade e

\footnotetext{
383 Ibidem. p. 57.
} 
experimentação da linguagem foram levados ao extremo da consciência, da página e da memória. Lévi-Strauss nos levaria a pensar a similaridade de nossa estrutura mental, enquanto seres que constroem mitos, muitas vezes, através de outros mitos e coletivamente. O desafio de se elaborar uma interpretação acerca de um mito torna-se duas vezes mais difícil se este mito for um mito moderno, ocidental e, conforme veremos, crítico. Um mito que é elaborado não pela mão coletiva da comunidade, mas por um crítico da civilização ocidental burguesa e europeia. Entretanto, de certa forma, ao interpretar o mito, em seu discurso de 3 a ordem, tanto Octavio Paz quanto LéviStrauss se tornam mitólogos: o primeiro, o mitólogo-poeta do mito moderno da crítica de Duchamp e o segundo, o antropólogo-mitólogo dos mitos ameríndios. Trata-se, pois, do mesmo procedimento, mas qualitativamente diferente.

O que possibilita esta ponte é a própria natureza do instrumento operacional com que trabalham tanto o poeta intérprete de certa antropologia cultural como o cientista engajado no seu trabalho de campo abstrato: a imagem-conceito. Para Paz,

\footnotetext{
"tanto Un coup de dés como Le cru et le cuit são aparatos de significações. Esta coincidência não é fortuita: Mallarmé antecipa muitas tentativas modernas, tanto na esfera da poesia, da pintura e da música como na do pensamento. Mallarmé parte do pensamento poético (selvagem) até o lógico e Lévi-Strauss do lógico para o selvagem. A anexação da razão lógica pelos símbolos da poesia coincide em um momento com a reconquista da lógica sensível pela razão crítica $^{384 "}$.
}

A convergência entre racionalidade crítica e imaginação poética faz parte do método analógico de Paz e quando o comparamos a uma estruturação epistemológica para a modernidade, é porque, para o autor, é possível perfilar neste conceito-imagem uma possibilidade de nos fazer refletir sobre aquilo que contém o dinamismo que, muitas vezes, escapa ao conceito e à própria dialética. Como já apresentamos, Paz sugere o uso operacional da imagem, em muitos casos, pois esta é capaz de estabelecer a linha de

384 Ibidem. p. 38. 
correspondências entre contraditórios que é vedada à razão crítica. E não há nada mais fugidio, cuja escapatória sempre se realiza mediante o conceito, que o instante.

Por esta razão, a etnografia de Lévi-Strauss operará uma crítica à abstração que revelou o tempo como progressivo. Sua crítica à ideia de história universal acompanha uma crítica ao progresso. Para que compreendamos o aspecto de tal crítica do progresso, devemos levar em conta que, para Benedito Nunes,

\footnotetext{
"a ascensão do progresso enquanto conceito de época passa tanto pela órbita do domínio tecnológico sobre a natureza, e, portanto, dos efeitos do agir sobre a Natureza que alcança nesse nosso século um grau demiúrgico de interferência sobre os processos naturais, quanto pela prospecção do futuro que caracterizou o pensamento iluminista ${ }^{385 "}$.
}

Nesse sentido, para Paz, como o progresso é nosso destino histórico, é natural que nossa crítica seja voltada a ele. Esta é, pois, nosso cuidado em relação ao nosso projetar-se na existência: projetamo-nos de uma forma crítica. Assim, Paz compreende que a etnografia de Lévi-Strauss é uma crítica a esta imagem de mundo e de tempo:

\footnotetext{
"a etnografia nasceu quase ao mesmo tempo que a ideia de história concebida como progresso ininterrompido; não é estranho que seja ao mesmo tempo a consequência do progresso e a crítica do progresso. É claro, Lévi-Strauss não o nega: situa em seu contexto o mundo do Ocidente moderno e assinala que não é uma lei histórica universal nem um critério de valor aplicável a todas as sociedades ${ }^{386 \prime \prime}$.
}

Em suma, se pudéssemos situar, portanto, o pensamento de Lévi-Strauss no escopo dos teóricos da história, este certamente se afiliaria àqueles que a concebem de forma interrupta. Podemos compreender esta atitude como sua resposta à crise generalizada

\footnotetext{
385 NUNES, Benedito. Crivo de Papel. São Paulo: Ed. Ática, 1998. p. 143.

${ }^{386}$ PAZ, Octavio. Ibidem. p. 72.
} 
do tempo histórico. Esta crise foi o que possibilitou o surgimento das concepções plurais e descontínuas de tempo, envolvendo a produção historiográfica num sentido mais particular, acerca das narrativas que "descartam as sínteses globais do desenvolvimento da humanidade ${ }^{387 \prime \prime}$ que a Historia Universal intentou realizar. Em suma, como já afirmamos, para Nunes, "tal aspecto revela que tempos particulares correspondem a essas histórias particulares; dedicando-se humanidades várias, elas trabalham com um tempo plural e não único ${ }^{388 "}$.

Nesse aspecto, a própria filosofia marxista admite um sentido amplo, pois, para Octavio Paz, assim se configura como uma utopia do tempo plural, onde o intuito da transformação revolucionária é o resgate de certa idade de ouro, como se explica abaixo:

\footnotetext{
"as utopias modernas tendem a apresentar-se como um regresso àquilo que não muda: a natureza. A sedução do marxismo consiste em ser uma filosofia da mudança que nos promete uma futura idade de ouro que já o passado remoto, "o comunismo primitivo", continha em gérmen. Combina assim o prestígio da modernidade com o do arcaísmo. Condenadas à mudança, nossas utopias oscilam entre os paraísos anteriores à história e as metrópoles de ferro e vidro da técnica, entre a vida pré-natal do feto e um éden de robôs. E de ambas maneiras os nossos paraísos são infernais: uns se resolvem no tédio da natureza incestuosa e outros no pesadelo das máquinas ${ }^{389 \prime \prime}$.
}

No interior desta metrópole de ferro e vidro, cuja técnica se faz imperiosa na vida cotidiana, sobretudo na esfera do trabalho, Paz vislumbra em Marcel Duchamp um resgate do erotismo, entretanto, um que não rompe com esses signos estéreis da modernidade, mas os põe em movimento analógico, de atração e repulsão, como na própria relação erótica. Contudo, como já apresentamos, a consistência da relação erótica na obra dependerá do engajamento do sujeito observador, tornado espectador participante. A obra de Duchamp arca com a impossibilidade de nos conectarmos à

\footnotetext{
387 NUNES, Benedito. Ibidem. p. 132.

388 Ibidem.

389 PAZ, Octavio. Ibidem. p. 78.
} 
nossa Idade de Ouro, por isso torna a ironia a linguagem-base de seu mito, o discurso de primeira ordem sobre o qual é construída a sua obra.

O domínio da técnica, operando sobre a natureza e sobre a linguagem, torna o acesso à Idade de Ouro da poesia e do mito um desafio, pois este depende de uma relação orgânica entre os seres humanos, onde o próprio pacto social - em seu sentido originário, como imaginara Rousseau - possa vir a se tornar um ato de comunhão. Por isso, para Paz,

\footnotetext{
"talvez a verdadeira idade de ouro não esteja na natureza nem na história, mas entre elas: nesse instante em que os homens fundam o seu agrupamento com um pacto que, simultaneamente, os une entre si e une o grupo com o mundo natural. O pensamento de Rousseau é uma fonte e Lévi-Strauss assinala que muitos dos descobrimentos da antropologia contemporânea confirmam suas intuições ${ }^{390 "}$ (Negrito nosso).
}

A intuição de Rousseau apontava que a origem da sociabilidade está nas paixões, isto é, na sensibilidade natural do selvagem que, na sua animalidade, reconhece no outro o mistério primordial do mundo. Novamente, a questão da outridade é posta no centro do pensamento de Paz. E, neste aspecto, a outridade surge como a condição de desenvolvimento de um pensamento que leva em conta a radical alteridade do outro, isto é, a sua peculiaridade única, sua essencialidade. Podemos observar que Octavio Paz situa o "pacto social" - isto é, este momento criativo em que os homens abandonam seu estado selvagem e abdicam da liberdade irrestrita que possuem, porém, não para fundar a propriedade privada - como aponta Locke -, mas para que os enlaces sociais, motivados pelas paixões, pela necessidade humana do outro, possam se desenvolver no instante. Ao situar este estado originário no instante, Paz nos permite dizer que ele é um instante que retorna, isto é, que pode se dar aqui e agora. Portanto, nesse sentido, o ser humano, um ser que é natureza e cultura, estado selvagem e história, é um ser que pode, através da irrupção temporal, se situar entre estes extremos, neste instante

390 Ibidem. p. 78. 
fundante, quando recobra a sua origem, ou seja, quando recobra a sua própria temporalidade: aquela que nos projeta no mundo e que nos situa num "aqui e agora".

Obviamente, Jean Jacques Rousseau aponta que, após o pacto, haverá a corrupção, no momento em que surge a desigualdade através da propriedade privada e da consequente degradação da humanidade através da razão. Ora, o pensamento de Rousseau, apesar de sua originalidade, resguarda certa influência do cristianismo, em sua acepção primitiva, uma vez que o francês afirma que, dos sentimentos naturais do ser humano, se sobressai a piedade natural. Contudo, para Octavio Paz, este sentimento, destarte representar a descoberta do outro no instante - neste instante que podemos chamar poético - quando ocorre no interior do cristianismo, vem acompanhado pelo remorso e pela culpa. Poderíamos situar, dentre os construtores da cultura cristã, Santo Agostinho, para quem o próprio sentido da temporalidade é uma experiência de introspecção e interioridade. Ao inventar a pessoalidade, o cristianismo estabeleceu uma relação do ser humano consigo mesmo, porém, através da experiência da confissão, onde Deus figura como mediador. Entretanto, já estava posta a figura da outridade em sua essência: o tu. Agostinho escreve as Confissões na segunda pessoa do singular, num monólogo com Deus, sempre se referindo a um outro que, apesar de sua distância - uma vez que nossa linguagem nos revela a nossa limitação diante do divino - podemos atingir por intermédio de nossa aventura interior.

Em relação a este processo de experiência da interioridade, Octavio Paz dirá que

\footnotetext{
“a introspecção é uma invenção cristã e termina sempre com um juízo moral, não sobre os outros mas sobre si mesmo. O exame de consciência consiste em pôr-se no lugar dos outros, ver-se na situação do humilhado ou do vencido: o outro. É uma tentativa para nos reconhecermos no outro e, assim, recuperarmos a nós mesmos. O cristianismo descobriu o outro e ainda mais: descobriu que o eu só vive em função do tu. A dialética cristã do exame de consciência é repetida pela etnografia não na esfera individual, mas na social: reconhecer no outro um ser humano e reconhecermos a nós mesmos não na semelhança, mas na diferença ${ }^{391 " .}$.
}

391 Ibidem. 
O que este paralelo com o cristianismo nos ensina é que antropólogo deve respeitar a alteridade radical, isto é, a outridade: recuperar o outro respeitando sua identidade/integridade. Porém, abandonando a expiação e a culpa cristãs, dado que a recuperação do outro não visa a aplacar a má consciência individual, mas restituí-lo como um ser cultural - um ser dotado de particularidade e, como nos mostra LéviStrauss, uma forma universal de razão que a todos aproxima.

Esta recuperação do outro na esfera do pensamento e mesmo da vida cotidiana está vinculada à forma analógica de se compreender o mundo e da extensão que esta percepção possui em nossos vínculos, bem como em nossos meios de conhecimento. Pensar a influência de Lévi-Strauss, a qual já apontamos ter sido parcial para Octavio Paz, é levar em conta a ressignificação do princípio da analogia, tão laboriosamente detalhado em obras como Os Filhos do Barro, ao lado do conceito de ironia. Em primeiro lugar, a sua transmutação ocorre por influência da noção basilar do estruturalismo francês: o conceito de estrutura. Segundo Maria Esther Maciel, o conceito tradicional de analogia, demarcado pela "relação de semelhanças, centrada na ideia de identidade sem frestas entre os termos", é transmutado num princípio que tende a não excluir o contraditório no interior de uma relação, agora não mais reduzida ao que possui similaridade, pois

\footnotetext{
"no conceito paziano o que se repete é o ritmo, entendido como um "campo de relações", cuja função, longe de ser a de anular as diferenças, é, sim, a de "atar alteridades", mostrando que isto é aquilo, sem que o isto e o aquilo deixem de ser independentes um do outro ${ }^{392 " .}$.
}

Com este princípio renovado, a ideia de alteridade radical - a outridade - ganha uma nova conotação: agora, a estrutura lhe embasa e nos mostra que a analogia está

\footnotetext{
392 MACIEL, Maria Esther. Voo transverso: Poesia, Modernidade e Fim do Século XX. Rio de Janeiro: Sete Letras, 1999. p. 122.
} 
presente, seja pela lógica binária (ou lógica analógica), nas mais diversas culturas do globo terrestre.

Nesta nova lógica analógica - contraposta à lógica analítica - a metáfora tornase o modelo da conjunção. A importância da metáfora está demarcada em Octavio Paz desde seu ensaio O Arco e a Lira, onde este apresenta o reino da poesia como "oxalá", ou seja, como uma expressão do desejo que se materializa na imagem. Esta, por sua vez, "é a ponte que o desejo constrói entre o homem e a realidade ${ }^{393 "}$. Entretanto, esta ponte, que poderia ser limitada pela conjunção lógica " $x$ é como $y^{394 ", ~ e x t r a p o l a ~ o ~}$ próprio princípio de identidade, onde o predomínio analítico indica que a única relação de identificação válida é a tautológica, onde $x=x$, e insere um rompimento da barreira que impedia $x$ de se identificar com $y$. Para Octavio Paz, a natureza deste tipo de metáfora - a qual poderíamos classificar como condição da outridade - "suprime o como e diz: isto é aquilo. Nela o desejo entra em ação: não compara nem mostra semelhanças, mas revela - [...] provoca - a identidade última de objetos que pareciam irredutíveis ${ }^{395 " .}$

A metáfora é a resposta do poeta diante do mundo. Ao assumi-la, podemos compreender qual é a base epistemológica sob a qual se desenvolvem a maior parte dos ensaios de Octavio Paz, caracterizados por um binarismo que se encontra nas ideias contraditórias de tradição e ruptura, analogia e ironia, conjunção e disjunção, movimento e imobilidade, tempo e eternidade, repulsão e atração, em suma, uma ponte que aproxima opostos. Ao assumir que os polos do Ser e do não-ser pertencem ao mesmo instante em movimento - à espiral que metaforiza o movimento de ausência e presença de significações - Paz sugere que, talvez, esta compreensão possa ser o que o autor chama de "Transparência", tendo em vista que o que transparece é o que possibilita o vislumbre das contradições e das formas internas, tal como a gema surrealista. Isso nos faz compreender que a escolha do poeta pela fala não subtrai o seu silêncio, o qual, aliás, pode ser compreendido de duas formas: "[uma], antes da palavra, é um querer dizer; [outra], depois da palavra, é um saber que não se pode dizer a única

\footnotetext{
393 PAZ, Octavio. O Arco e a Lira. Trad. Ari Roitman e Paulina Wacht. São Paulo: Cosac Naify, 2012. p. 73. ${ }^{394}$ MACIEL, Maria Esther. Ibidem. p. 124.

395 PAZ, Octavio. Ibidem.
} 
coisa que valeria a pena dizer-se $\mathrm{s}^{396 \prime}$. Um pertence ao âmbito do desejo, que estabelece a ligação entre homem e realidade: é o fundamento próprio da analogia; o segundo, a consciência de que no centro da analogia há um oco: "a pluralidade de textos implica que não há um texto original397", ou seja, a consciência de que "o mundo é ilegível" e que não há um grande livro do universo e, se há, ele se resume a uma proposição provisória, o "se" mallarmaico. Trata-se do momento em que, após o jorro verbal e a realização máxima da volição poética, o silêncio é acompanhado da melancólica sapiência de que "a analogia acaba em silêncio 398 ".

Portanto, a caracterização do método analógica não é a de um tipo de saber que busca uma verdade límpida, na clareza e na distinção dos conceitos, ele é uma operação que estabelece correspondências movidas pelo espírito aglutinador do pensamento poético. Porém, este procedimento combinatório obedece à rigorosidade. Para Maciel,

\footnotetext{
“Octavio Paz, devoto da metáfora, atribui a ela um poder de desdobramento quase que infinito. Poder que, segundo ele, é inerente a todo procedimento analógico, uma vez que, como atestou Lévi-Strauss, todo sistema de relações engendra outro, numa cadeia contínua ${ }^{399 "}$.
}

Ora, esse engendramento contínuo é o que permite Paz estabelecer correlações entre o próprio pensamento de Lévi-Strauss e a Índia, onde este reconhece na teoria que desvenda o sistema de relações estruturalista uma conclusão similar à intuição oriunda do pensamento budista. Para Octavio Paz, em uma nota explicativa de Claude LéviStrauss ou o Novo Festim de Esopo, esta similaridade não possuía uma motivação acidental, pois "o pensamento humano é uno e devemos a Lévi-Strauss [...] haver

\footnotetext{
396 Id. Claude Lévi-Strauss ou o Novo Festim de Esopo. Trad. Sebastião Uchoa Leite. São Paulo, SP: Ed. Perspectiva, 1993. p. 104.

397 PAZ, Octavio. Os Filhos do Barro. Trad. Ari Rotiman e Paulina Wacht. São Paulo: Cosac Naify, 2013. p. 79.

398 Ibidem. p. 83.

${ }^{399}$ MACIEL, Maria Esther. Ibidem. p. 124.
} 
demonstrado que a razão do primitivo ou a do oriental não é menos rigorosa do que a nossa ${ }^{400 \prime \prime}$.

Ao finalizar seu ensaio, Octavio Paz empreende uma crítica à subjetividade moderna. Lévi-Strauss rompe com a parelha sujeito-objeto e invoca algo novo em seu lugar: a transparência. Porém, antes de reconhece-la no antropólogo, podemos afirmar que Paz já se valia desta ideia, encontrando no francês mais uma de suas aparições: um eco que talvez explique a universalidade da razão analógica. Em Os Filhos do Barro, ao finalizar a sua explicação acerca do caráter entrelaçado entre ironia e analogia e pensar, assim, a constituição do poema, Paz desloca a autoria do sujeito (o autor) para a própria linguagem: esta opera no mundo de uma forma autônoma, universalizante, de modo que nós, unitária e particularmente, Ihe compomos as partes. Paz explica: "não quero dizer que a linguagem suprima a realidade do poeta e do leitor, mas sim que as compreende, engloba: o poeta e o leitor são apenas dois momentos existenciais da linguagem ${ }^{401 "}$ ". Em suma, a ideia do poeta como o tradutor do universo, onde sua obra Ihe possibilita desvelar ou decifrar este cosmo repleto de signos contrários, passíveis de corresponderem-se entre si, leva ao "desaparecimento do autor ${ }^{402 "}$. A poesia como presença ou como transparência evoca o devir da linguagem, em seu estado puro selvagem - a operar de uma maneira que nós sejamos seus leitores ou escritores e nos deixemos fluir pelo seu ritmo próprio. Para Paz, o movimento de oscilação entre os polos analogia e ironia cria a imagem espiralada do caracol, o qual representa um "poema anônimo coletivo do qual cada um de nós, mais do que autor ou leitor, é uma estrofe, um punhado de sílabas ${ }^{403 "}$.

Por esta via, na escrita, quando o autor e o leitor são coordenados pela linguagem, para Roland Barthes em A morte do autor, é onde

\footnotetext{
${ }^{400}$ PAZ, Octavio. Op. Cit. p. 91.

401 PAZ, Octavio. Os Filhos do Barro. Trad. Ari Rotiman e Paulina Wacht. São Paulo: Cosac Naify, 2013. p. 80.

402 Ibidem

${ }^{403}$ Ibidem. p. 144.
} 


\begin{abstract}
"a estrutura pode ser seguida, "apanhada» (como se diz de uma malha de meia que cai) em todas as suas fases e em todos os seus níveis, mas não há fundo; o espaço da escrita percorre-se, não se perfura; a escrita faz incessantemente sentido, mas é sempre para o evaporar; procede a uma isenção sistemática do sentido, por isso mesmo, a literatura (mais valia dizer, a partir de agora, a escrita), ao recusar consignar ao texto (e ao mundo como texto) um "segredo", quer dizer, um sentido último, liberta uma atividade a que poderíamos chamar contraideológica, propriamente revolucionária, pois recusar parar o sentido é afinal recusar Deus e as suas hipóstases, a razão, a ciência, a lei" ${ }^{404}$.
\end{abstract}

Ou seja, a escrita é uma realidade rebelde, avessa às reduções psicológicas, subjetivas, históricas e biográficas. Octavio Paz é consciente desta rebeldia, uma vez que, para o mexicano, a correspondência entre o gesto rebelde e a palavra poética se dá graças a esta compreensão do tempo como o instante inefável e fundante em que ambas ocorrem. O fato de se conceber a metáfora como o signo que sempre desemboca em outra metáfora, nos permite afirmar que a malha de metáforas que constitui a literatura e a poesia, assim como a própria filosofia, não nos permite nunca identificar a original. Persegui-la é como perseguir o tempo: uma tarefa inglória acerca de um objeto que nunca se constitui como um objeto, posto que movente, posto que metafórico. Nesse sentido, o tempo é astuto, como elegantemente nos explica Benedito Nunes,

\footnotetext{
“à semelhança de Snark, aquele extravagante bicho do poema homônimo de Lewis Carroll, que se antecipava aos caçadores, nunca estando onde o procuravam, o tempo escapa a toda tentativa de representa-lo, e toda representação sua, muito mais imagem do que conceito, incorpora, de antemão, metaforicamente, o espaço por onde corre o rio e se estende a corrente líquida ${ }^{405 "}$.
}

Perscrutar a origem da metáfora ou a origem do próprio tempo nos leva a vacilar, pois a própria subjetividade se transforma quando nos pomos a busca-lo, pois o próprio

\footnotetext{
404 BARTHES, Roland. A morte do autor In O Rumor da Língua. Lisboa: Edições 70, 1970. [Texto disponível on-line a 21-01-2007 através de http://www.facom.ufba.br/sala de aula/sala2/barthes1.html].

${ }^{405}$ NUNES, Benedito. Crivo de papel. São Paulo: Ed. Ática, 1998. p. 135.
} 
tempo é metáfora: a exemplo do rio heraclitiano, onde mudamos à medida em que o tempo transcorre em nós e através de nós. Regidos pela transparência, a dissolução do sujeito impossibilita uma epistème que abstraia, detenha, apreenda o tempo, mas fomenta uma que o vivencie enquanto uma experiência correlata à própria vida.

A "morte do autor", em Roland Barthes, cujo acontecimento deve se concretizar para que a escrita reencontre seu devir, este devir que leva uma metáfora a engendrar outra, significa, para Paz, a transparência, cuja definição o poeta nos dá em seu contexto filosófico:

\begin{abstract}
"para Kant, há um sujeito e um objeto; Lévi-Strauss apaga essa distinção [pois dissolve o entendimento na natureza]. Em lugar do sujeito, postula um "nós" feito de particularidades que se opõem e combinam. O sujeito se via a si mesmo e os juízos do entendimento universal eram os seus. O "nós" não pode ser visto: não tem um si mesmo, sua intimidade é exterioridade. Seus juízos não são seus: é o veículo de um juízo. É a estranheza em pessoa. Nem sequer pode saber-se uma coisa entre as coisas: é uma transparência através da qual uma coisa, o espírito, contempla as outras coisas e se deixa contemplar por elas. Ao abolir o sujeito, Lévi-Strauss destrói o diálogo da consciência consigo mesma e o diálogo do sujeito com o objeto ${ }^{406 " \text {. }}$
\end{abstract}

Não há mais sujeito porque não há mais polos opostos, regidos por hierarquias e funções preestabelecidas. O que nos vê é o que vemos, quando o vemos: ao nos habitar poeticamente, a linguagem e seus poderosos efeitos de atração e repulsão, erotiza o nosso universo. Ora, qual o significado do ato de significar? Para Paz, o que a experiência na Índia e o contato com Claude Lévi-Strauss ensinaram é que o sentido do significar é a própria operação de significar, isto é, a relação ${ }^{407}$.

Em de seus poemas epigramáticos, Octavio paz apresenta esta ideia de forma bastante viva. Em Cifra, um de seus Topoemas, Paz elabora um poema composto por oito versos, dentre os quais quatro são a palavra "como", à qual, corresponde a função

\footnotetext{
${ }^{406}$ PAZ, Octavio. Claude Lévi-Strauss ou o Novo Festim de Esopo. Trad. Sebastião Uchoa Leite. São Paulo, SP: Ed. Perspectiva, 1993. p. 96.

407 Ibidem. p. 102.
} 
de estabelecer a ligação entre os termos que, no interior deste poema, movem-se como uma metáfora que gira. Este poema representa a coincidência de opostos, ou seja, como no interior da própria linguagem, há um movimento que nos possibilita interliga-los. 0 criptograma também possui uma dimensão de desenho, uma vez que, disposto no papel, revelando os espaços em branco como funcionais na sua linguagem, ele sugere uma abstração que é, por um lado, filosófica, graças aos conceitos em movimento neste esquema, e por outro, gráfico, visto que sua disposição suporta uma fusão do desenho com as palavras. Acerca deste poema, Paul Henri Giraud nos lembra que "também a primeira edição de Topoemas acrescentava: "Neste poema, a rotação das palavras

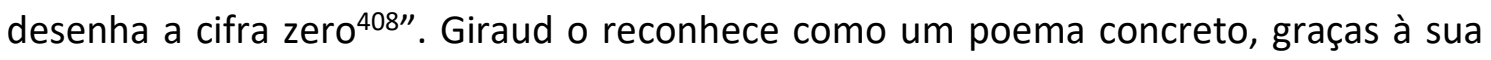
disposição tipográfica:

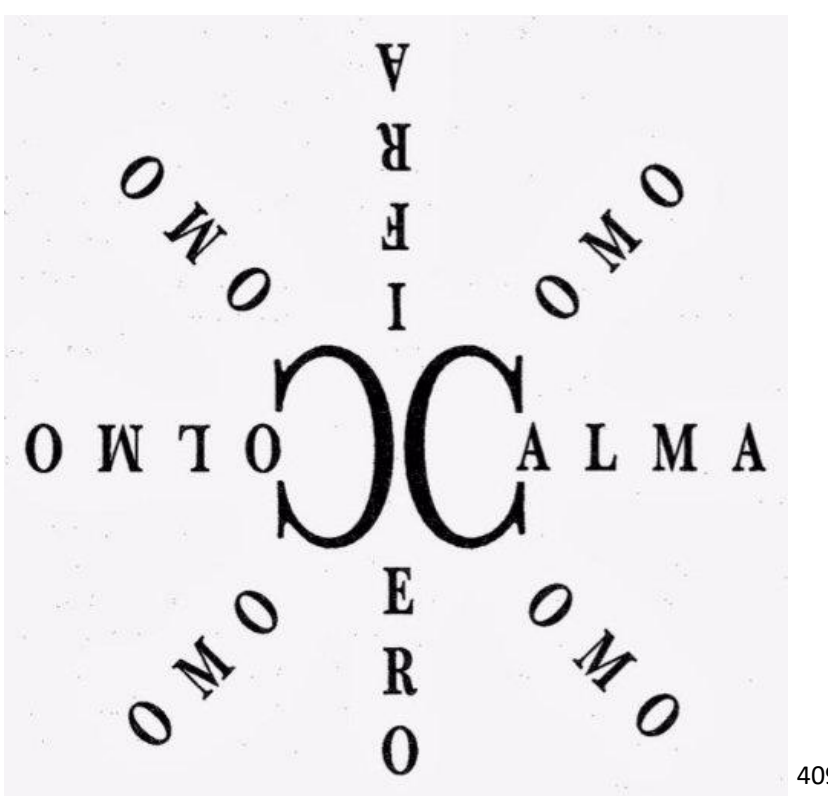

A conjunção entre os opostos (zero (cero) e cheio (colmo)) sugere a contraposição entre os princípios no interior da vacuidade. Paz explica, acerca deste poema, que ele é um resgate etimológico de uma forma ancestral de designar as ideias cujo sentido originário

408 GIRAUD, Paul Henri. Octavio Paz: caminho para a transparência. Trad. António Teixeira. Lisboa: Instituto Piaget, 2002. p. 380.

409 PAZ, Octavio. Topoemas In Signos em Rotação. Trad. Sebastião Uchoa Leite. São Paulo: Perspectiva, 2009. p. 93. 
já abarcava, em seu próprio interior, os opostos da ideia evocada. Por esta razão, ele diz, citando Edward Conze em Buddhism que "nossos antepassados, com um instinto certo de natureza dialética da realidade, utilizavam frequentemente a mesma raiz verbal para denotar os dois aspectos opostos de uma situação410". Desta forma, o significado original de cifra abarca o par binário vazio-cheio, bem como indica sua origem arábica sifr (zero, vazio), "palavra que não é nada senão o sanskrit shûnya, derivado da raiz svi, inchar ${ }^{411 " . ~ A ~ v a c u i d a d e ~ n a ̃ o ~ e ́ ~ e q u i v a l e n t e ~ d o ~ " N a d a ", ~ p o i s, ~ c o m o ~ i n d i c a ~ o ~ p a r ~ r e l a c i o n a l, ~}$ ela abarca em seu interior o seu contrário, isto é, o "todo". Se cúmulo é o ponto ou grau mais alto - o auge -, aqui ele é reconciliado à Calma: sensação do instante de plenitude em que vislumbramos a totalidade (vacuidade) indivisível, cujas contradições - jamais solucionada - foram superadas por uma ligação analógica. Quando este poema rotacional gira, suas diferenças se apagam e da vacuidade retemos a calma que nos nadifica. A vacuidade vazia imprime uma negação do ego e, feita esta negação, o que sobra? No caso deste poema, nos resta a essência da própria palavra, pois o zero continua a girar à medida em que nossa linguagem permanecer eterno movimento, ou seja, contínuo engendrar de metáforas, onde seu autor, conforme dissemos acima, é a própria linguagem:

\footnotetext{
“a essência da palavra é a relação e daí que seja a cifra, a encarnação momentânea de tudo o que é relativo. Toda palavra engendra uma palavra que a contradiz, toda palavra é relação entre negação e uma afirmação. Relação é atar alteridades, não resolução de contradições. Por isso, a linguagem é o reino da dialética que sem cessar se destrói e renasce só para morrer. A linguagem é dialética, operação, comunicação ${ }^{412 "}$.
}

No final desta mesma obra, em nota explicativa, Octavio Paz dirá que Heidegger se propôs algo semelhante a Lévi-Strauss, no que corresponde à compreensão de um

\footnotetext{
${ }^{410}$ GIRAUD, Paul Henri. Ibidem. p. 379.

411 Ibidem.

412 PAZ, Octavio. Claude Lévi-Strauss ou o Novo Festim de Esopo. Trad. Sebastião Uchoa Leite. São Paulo, SP: Ed. Perspectiva, 1993. p. 104.
} 
entendimento universal regido por leis e categorias invariáveis, porém, mais na esfera da temporalidade, como enunciada na obra Ser e Tempo.

O escritor José Gaos, tradutor de Ser e Tempo, essencial para que Paz viesse a conhecer o filósofo alemão, nos explica que a temporalidade é a maneira como se manifesta, na existência, o Ser-aí, isto é, o ser do homem. Em primeiro lugar, coloca-se em cheque as categorias "cotidianas" de passado e futuro, enquanto manifestações do tempo que são dotadas de certo aspecto ontológico. Para Heidegger, elas apenas significam o que já não é mais e o que ainda não é. Para o espanhol,

\footnotetext{
"si se toma el "ser ahí" como "futuro" o "pasado", no se le toma en su verdadera realidad. En ésta sólo se le toma cuando se le toma en tanto es. Sólo podemos tomarnos a nosotros mismos como no habiendo sido o no habiendo de ser, en cuanto estamos siendo realmente". En cualquier momento de nuestro ser en que nos tomemos, encontraremos que somos adviniendo, que somos sidos y que somos presentando ${ }^{413 \prime \prime}$.
}

Aquilo que advém, o que já se foi (o "ser sido" - e neste sentido, Gaos nos diria que é uma infelicidade o espanhol e o português, como as línguas neolatinas em geral não fazerem do próprio verbo "ser" um verbo auxiliar nesta conjugação) e o que se passa presentemente (presentando) compõe, de uma forma tríplice, uma unidade completa. Esta seria, pois, a "estrutura" da condição temporal por meio da qual se manifesta em nós o Ser. Se não há um "ser aí", tampouco há um mundo, tampouco há existência. $\mathrm{A}$ temporalidade é o sentido e a possibilidade de que os entes se expressem - isto é, tomem frente - no mundo. Para Gaos,

\footnotetext{
"el "problema de la trascendencia" del mundo no es el de "cómo salga de sí un sujeto para llegar hasta un objeto, a la vez que se identifica la totalidad de los objetos con la idea del mundo", sino el de "qué es lo que hace posible ontológicamente que hagan frente entes dentro del mundo y puedan
}

\footnotetext{
413 GAOS, José. Introducción a El Ser y el Tiempo de Martin Heidegger. 2a ed. México: Fondo de Cultura Económica, 2017. p. 80.
} 
objetivarse como entes que hacen frente", y la solución de este problema es la aprioridad o trascendencia, a los intramundanos, del mundo, hecho a su vez posible por la temporalidad en la forma expuesta ${ }^{414 "}$.

A manifestação do Ser em seu sentido temporal, através do ser-aí, é a própria condição de existência do mundo. De forma similar, Paz nos diz que imagem de tempo é imagem de mundo. Distinta da representação, os entes deste mundo se apresentam a nós, são dados da percepção postos no tempo. Assim, o tempo se nos apresenta e a linguagem poética permitirá dizer que uma das formas pela qual o tempo se encarna é a da espiral: o caracol, sua metáfora.

Para Octavio Paz, esta metáfora do tempo é também uma imagem do tempo plural que rege a nossa sociedade, posto que em seu interior coabitam as formas linear e a cíclica. Contudo, ao contrário do tempo da modernidade, a imagem do caracol é resistente à ideologia do Progresso, para quem o que importa é a velocidade das mudanças, a subserviência do presente a um futuro abstrato. Esta imagem, espiralada, imóvel e movente ao mesmo tempo, é extraída de Tristes Tópicos, apesar de aparecer também em outras obras e poemas - como se verá adiante. Para o mexicano,

\footnotetext{
“o pensamento alcança nessas poucas páginas uma densidade e uma transparência que fariam pensar nas construções do cristal de rocha, não fosse o caso de estar animado por uma palpitação que não recorda tanto a imobilidade mineral como a vibração das ondas de luz. Uma geometria de resplendores que adota a forma fascinante da espiral. É o caracol marinho, símbolo do vento e da palavra, signo do movimento entre os antigos mexicanos: cada passo é simultaneamente uma volta ao ponto de partida e um avançar para o desconhecido. Aquilo que abandonamos ao princípio nos espera, transfigurado, ao final. Mudança e identidade são metáforas do Mesmo: se repete e nunca é o mesmo ${ }^{415 "}$.
}

\footnotetext{
414 Ibidem. p. 96.

415 PAZ, Octavio. Claude Lévi-Strauss ou o Novo Festim de Esopo. Trad. Sebastião Uchoa Leite. São Paulo, SP: Ed. Perspectiva, 1993. p. 100.
} 
Duplo-Regresso, este Tempo-metáfora é um ponto de convergência entre as sociedades cujo tempo ainda não enveredou pela sucessão histórica e as sociedades para quem a concepção do tempo não pode admitir a ausência de historicidade. A percepção do tempo como caracol envolve a consciência de que a cada começo, seja novo ou seja o resgate de uma origem obliterada ao longo da história, envolve necessariamente um fim. Ou seja, por mais que nossa sociedade consagre o tempo móvel e a novidade, a previsibilidade do fim, da interrupção do tempo e do esgotamento de toda marcha que se proponha ser única, é a certeza de que entre a mobilidade e a imobilidade - "sempre iminente e sempre inabalável ${ }^{416 " ~-~ h a ́ ~ a p e n a s ~ u m a ~ d i f e r e n c ̧ a ~ d e ~ g r a u, ~ p o i s ~ " o ~ t e m p o ~}$ também é uma metáfora e seu transcorrer é tão ilusório como os nossos esforços para detê-lo: nem transcorre nem se detém ${ }^{417 " \prime . ~}$

A imagem do caracol é a que melhor metaforiza o tempo pois nos mostra um animal para quem a distinção entre a mobilidade e a imobilidade parece uma troça de sua natureza. De certa forma, esta imagem flerta com a ideia de eternidade, porém, dado toda a crítica de Octavio Paz a esta concepção, sobretudo em sua versão cristã. A eternidade paziana, se está ancorada em algo, é no instante e nas experiências compartilhadas que ele pode propor, emular, criar. Portanto, para que consigamos compreendê-la, é necessário que tenhamos em mente como ela opera no interior da própria poesia do mexicano, isto é, como Octavio Paz torna o instante não apenas um operador categorial por onde somos capazes de compreender a festa, a revolta e a sua visão justaposta da história, mas também o instante mais inabalável de todos os instantes, a experiência mais completa, à qual pouco nos detivemos até este momento de nossa dissertação: o amor. O amor e o erotismo figuram como as experiências capazes de fazer torcer o tempo, transfigurar nossa imagem de mundo, e nos pôr em contato com este instante eterno - não graças a sua imobilidade, mas graças a sua vivacidade, à sua riqueza de experiências e intensidade, local por excelência da manifestação da outridade. Ora, nela, todo dizer é supérfluo, pois limitante diante do seu grau de complexidade e, por se configurar, talvez, como o desafio que Octavio Paz

\footnotetext{
416 Ibidem. p. 101.

417 Ibidem.
} 
buscou compreender toda a sua vida - como o poeta mesmo revela em A Dupla Chama - ele aplaina toda a sua superfície, seja na poesia ou no ensaio. 


\section{Itinerário poético: o Mito, o Amor e a História.}

\section{Pedra de Sol: o poema enquanto recriação do calendário e do mito}

Em um de seus poemas mais importantes, Pedra de Sol, escrito em 1957, Octavio Paz inicia os 584 versos com a seguinte sexta:

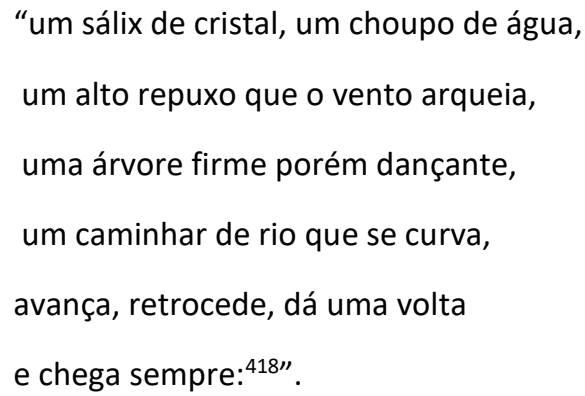

O poema hendecassílabo termina repetindo os mesmos versos iniciais, indicando uma circularidade, uma repetição de seu início, em suma, um eterno-retorno que continua, uma vez que esta continuidade é indicada pelos dois pontos que fecham o verso em sua cesura, tal como o poema Eternidade de Rimbaud, que realiza a mesma operação de repetir a primeira estrofe no fim, indicando, assim a imagem da circularidade que se refaz a cada instante:

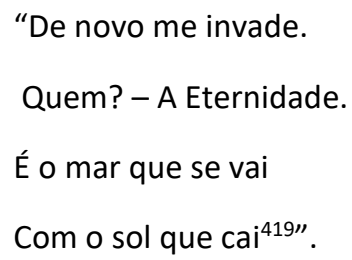

Ora, como o próprio nome sugere, Pedra de Sol é, na verdade, o gigantesco calendário asteca hoje presente no Museu de Antropologia Nacional, localizado na Cidade do México. Ainda que seja um objeto histórico, pertencente à cultura indígena mexicana,

\footnotetext{
418 PAZ, Octavio. Pedra de Sol. Trad. Horácio Costa. São Paulo: Annablume, 2009. Pag. 7.

419 RIMBAUD, Arthur. Eternidade In Rimbaud Livre. Trad. Augusto de Campos. São Paulo: Perspectiva, 2013. p. 51.
} 
não é unicamente sob o prisma histórico que ele é introduzido no poema de Paz, pois é preciso ter em mente que a própria estrutura deste poema emula a raiz da temporalidade mítica, a temporalidade cíclica, do povo pré-colombiano. Ao possibilitar que esta temporalidade originária ressurja sob a rotação de outros signos linguísticos, o mexicano revive a imagem de tempo e a realoca ao presente. Com o devido distanciamento histórico? Certamente diríamos que não, pois cabe explorar neste trabalho como a poética de Paz possibilita um movimento como este, um movimento que conjuga no poema uma convergência da imagem temporal presente com o mito trans-histórico, com a história e com a linguagem, de uma forma que a imagem ressurreta aparece diante de nós, nua, tal qual uma reminiscência. Diferente do mero documento, a imagem poética rompe o distanciamento histórico.

Sobre a temporalidade mítica, subjaz ao poema a correspondência dos 584 versos aos dias do calendário venusiano. O ciclo do astro que, no imaginário míticoasteca, representava o deus Quetzalcóatl-Ehécatl. A presença deste símbolo divino híbrido (parcialmente cobra e ave), ainda que implícito no poema, nos sugere duas coisas. Segundo Horácio Costa, poeta e tradutor de Paz,

\footnotetext{
“enquanto a ave é marcada pela potência da migração, da mobilidade, da ascensão a estados superiores do ser, da sublimação e guarda em si a capacidade de renovação [...], a serpente, principalmente em sua configuração de Roda [...] exemplifica o ciclo da vida e da morte, a invariabilidade, a repetição infinita da dialética matéria-espírito, dinamismo que se dá num lugar fora de todos os lugares, mobilidade imóvel que aponta para a pulsação cósmica ${ }^{420 » "}$.
}

Em suma, o duplo perecibilidade e renovabilidade é inserido no interior do próprio eterno-retorno, princípio que para Paz opera tal como o conceito trágico nietzschiano. Contudo, ainda que possamos associá-lo ao princípio de Nietzsche, a menção à circularidade é referência direta à própria estrutura do calendário asteca, ao monumento de pedra. Para que consigamos comprendê-lo, é necessário entendermos

${ }^{420}$ COSTA, Horácio. Nota do Tradutor In PAZ, Octavio. Pedra de Sol. São Paulo: Annablume, 2009. Pag. 74. 
a importância da figura de Quetzalcóatl, subjacente a este poema, apesar de não nomeada explicitamente. Ainda segundo Costa,

\begin{abstract}
"como serpiente emplumada, la identidad de Quetzalcóatl-Ehécatl revela ya una dualidad estructural: por un lado es réptil, animal rastrero, o sea, de principio nocturno, que asume la psyché inférieure, le psychisme obscur que, a su vez, es asociado al principio del mal en casi todas las mitologías. Por otro lado, la serpiente se vincula a la idea primordial de ciclo, siendo aquella que muerde su rabo la expresión de "la dialéctique matérielle de la vie et de la mort", según Bachelard. En esta configuración cíclica, la serpiente se equipara a la primera rueda, inmóvil sólo en apariencia pero que gira incesantemente sobre sí misma ${ }^{421 "}$.
\end{abstract}

O tempo cíclico do monólito é o símbolo que está na espessura da forma deste poema.

Portanto, não seria desmesurado assegurar que Quetzalcóatl é umas das imagens de tempo que fundamentam o terreno sobre o qual Paz constrói seus versos. Em O novo festim de Esopo, o poeta nos diz que Quetzalcóatl

\begin{abstract}
"é um mito de emergência (a origem do homem) e um mito de trânsito; é a imagem do tempo, a encarnação em movimento, seu fim e sua transfiguração (a autoimolação pelo fogo e sua metamorfose em planeta). [...] A pluralidade de sociedades que adotaram e modificaram o mito proíbe estuda-lo por meio do método histórico. $O$ único adequado, assim, seria o de Lévi-Strauss. Aponto, por ora, algo evidente: a história de Quetzacóatl é na realidade um conjunto de histórias, uma família de mitos ou, mais exatamente, um sistema ${ }^{422 "}$.
\end{abstract}

Contudo, ao veicular o mito como uma das estruturas de seu poema, Paz utiliza a sua imagem como um dispositivo formal sobre o qual apresentará o surgimento do princípio

\footnotetext{
${ }^{421}$ COSTA, Horácio. Piedra de Sol: el título in Mar Abierto: ensayos sobre literatura brasileña, portuguesa e hispanoamericana. Ciudad de México: Fondo de cultura económica, 2000. p. 347.

422 PAZ, Octavio. Claude Lévi-Strauss ou o Novo Festim de Esopo. Trad. Sebastião Uchoa Leite. São Paulo, SP: Ed. Perspectiva, 1993. p. 30.
} 
capital desta obra, o instante. Será, portanto, no interior desta noção que Paz desdobrará toda a sua poética e seu pensamento, pois a busca da outridade só poderá se dar no interior de uma determinada temporalidade, no interior de um instante específico, o poético - análogo ao amoroso.

Em O Arco e a Lira, escrito em 1956, um ano antes do poema, o autor compreende o instante poético assim:

"como através de um corpo amado entrevemos uma vida mais plena, mais vida que a vida, através do poema entrevemos o raio fixo da poesia. Esse instante contém em si todos os instantes. Sem deixar de fluir, o tempo se detém, repleto de $\mathrm{si}^{423 \prime \prime}$.

Ou seja, este instante da eterna vivacidade, por meio do qual a imagem poética se nos oferece e a linguagem impera sobre o poeta, é a marca de uma interrupção do fluxo que, não obstante, não interrompe o tempo, necessariamente, mas nos coloca em outro regime de vibração rítmica. Não por menos, em outros textos, Paz se referirá a uma das matrizes desta ideia - a surrealista - como instante "elétrico". No apêndice pertencente à mesma obra, intitulado "A nova analogia: poesia e tecnologia", Paz acrescenta à noção: "Quer dure um século ou o tempo de um piscar de olhos, esse instante é incomensurável. É o único paraíso aberto aos homens, desde que se esqueçam de si mesmos $^{424 "}$. É o instante que vem e o que retorna, como os versos iniciais do poema.

Outra referência à circularidade do tempo pode ser encontrada já na epígrafe deste poema, nos versos de Gerard de Nerval, onde este afirma

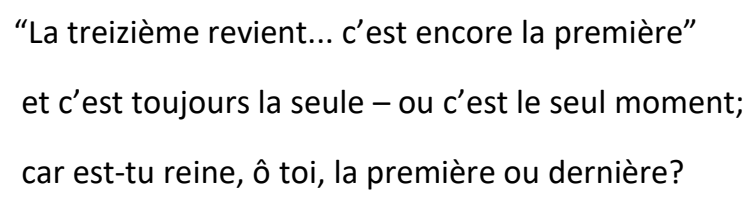

${ }^{423}$ PAZ, Octavio. O Arco e a Lira. Trad. Ari Roitman e Paulina Wacht. São Paulo: Cosac Naify, 2012.

${ }^{424}$ Ibidem. Pag. 337. 
es-tu roi, toi le seul ou le dernier amant? ${ }^{425 " .}$

O ciclo temporal destes versos nervalinos representa a rotação dos ponteiros do relógio. A décima terceira (hora) retorna, é ela a primeira ou é a última? Ao se questionar acerca deste instante que irrompe agora, Nerval confunde-se com as horas. Confude-se, pois o tempo em que se dá o encontro, o instante em que se nos apresenta le dernier amant é um instante que não se comensura e não se submete à sombra do relógio. Em sua tradução deste poema, intitulado Artemisa, Octavio Paz verseja:

\footnotetext{
“Volta outra vez Décima Terceira - és ainda a primavera!

E és sempre a única - ou és o único instante ${ }^{426}$ ?".
}

O instante ao qual Paz se refere nesta tradução é o instante amoroso. Podemos, inclusive, indagar se, ao se questionar se "és sempre a única", o poeta faz menção aqui às horas ou à mulher que idealiza nestes versos? Será o instante amoroso sempre o mesmo? Será o encontro amoroso sempre o mesmo, a despeito daquela ou daquele que vem? A circularidade do poema lança a questão sobre a própria natureza do sentimento amoroso: trata-se de um instante cujo acontecer irrompe como um segundo novo em nossa existência ou ele é a repetição da hora já realizada, tal qual uma nova volta do ponteiro do relógio? Segundo Paul Henri Giraud, o amor é um reino acedido pela transparência, o que significa, por sua vez, que o tempo, enquanto dúvida e mistério tem que "as suas variações, a variedade do mundo, não passam, talvez, de uma ilusão, talvez haja apenas um "só momento" - ou, melhor, um "único instante", que se volta a fechar, concentrado, tal semente de eternidade sempre pronta a germinar ${ }^{427 "}$. O que se percebe é que, para Paz, o tempo enquanto imagem abarca em seu interior uma tensão entre continuidade e imobilidade, irrupção e processo. $\mathrm{O}$ instante, enquanto categoria operacional do tempo ou, enquanto princípio motor de nossa temporalidade, é uma

\footnotetext{
425 PAZ, Octavio. Pedra de Sol. Trad. Horácio Costa. São Paulo: Annablume, 2009. p. 5.

${ }^{426}$ PAZ, Octavio. Artemisa In GIRAUD, Paul Henri. Octavio Paz: caminho para a transparência. Trad. António Teixeira. Lisboa: Instituto Piaget, 2002. p. 242.

${ }^{427}$ GIRAUD, Paul Henri. Ibidem.
} 
manifestação que possibilita que este par coabite, apesar de sua contrariedade aparentemente insolúvel.

Contudo, o que faz um calendário senão, a partir da conjunção de imagens de tempo distintas, seccionar a correnteza do tempo em instantes memoráveis? Paz reconhece que a natureza do objeto-símbolo de seu poema é mítica, mas ressalta que é também um elemento sujeito às regras da história. Se o poema é, por um lado, experiência pessoal - se lembramo-nos dos fatos que ocorrem conosco como instantes basilares a compor nossa biografia e, geralmente, rememoramo-los à medida em que os dias do calendário os fixam na esteira do passado, então a criação coletiva e cultural também tem de lidar com a presença do calendário. Ao colocar a figura do calendário no centro de seu poema, Paz nos sugere que é possível fazer uma reconstituição de aspectos perecíveis de nossa sensibilidade, de nossas formas de sentir e amar, que podem ser reencontrados no seio do tempo histórico ou diante da fulguração (nem sempre imponente, pois muitas vezes decadente) de uma imagem mítica e arquetípica que se faz presente. Apontaremos como isso aparecerá no poema adiante. Antes, devemos compreender como se pode compreender esta noção de calendário. Para Costa, "la noción misma del calendario expresa el deseo muy humano de establecer un orden aparentemente coherente que sólo se puede mantener - más bien como una promesa de realización tangible -, mientras sea repetida infinitamente ${ }^{428 "}$. O calendário é a imagem que nos mostra que, na unidade deste poema, figura o tempo plural. Neste entremeio de calendários, o cristão e o asteca, existe a mediação da história.

Ainda na primeira página deste poema, Octavio Paz aloca um dos signos históricos que melhor simbolizam o tempo: a água. Não por menos, a primeira estrofe descreve "um caminhar de um rio que se curva,/ avança, retrocede, dá uma volta e chega sempre:" - como uma pintura do princípio circular que rege a temporalidade do guarda-Sol mexicano, a Pedra. Na segunda estrofe, temos a

\footnotetext{
“água que com as pálpebras fechadas
}

\footnotetext{
${ }^{428}$ COSTA, Horácio. Piedra de Sol: el título in Mar Abierto: ensayos sobre literatura brasileña, portuguesa
} e hispanoamericana. Ciudad de México: Fondo de cultura económica, 2000. p. 350. 
profecias emana a noite inteira, unânime presença marulhante ${ }^{429 "}$.

O marulho, esta conjunção silogística entre mar e "barulho", talvez seja uma das palavras mais ricas da língua portuguesa por nos mostrar, de forma simples, como opera o raciocínio analógico. Contudo, seu correlato em espanhol possui características vitalícias que merecem consideração. "Oleaje" é uma palavra que emula foneticamente o movimento das ondas, graças a seu caráter onomatopeico, descrevendo desde o precipitar da crista da onda até o momento em que ela se choca, dando origem ao surgimento da espuma que se desfaz e principia uma nova onda. Octavio Paz fará recurso a esta palavra não apenas em Pedra de Sol. Em El mono gramatico, oleaje será uma metáfora não apenas do movimento de ir e vir - proceder e retroceder - das ondas, mas terá seu duplo no movimento erótico do poeta com Esplendor, sua amante:

"La luz de la hoguera se enrosca a los tobillos de Esplendor y asciende entre sus piernas hasta iluminar su pubis y su vientre. El agua color de sol moja su vello y penetra entre los labios de la vulva. La lengua templada de la llama sobre la humedad de la crica; la lengua entra y palpa a ciegas las paredes palpitantes. [...] Nudos. Sobre el cuerpo tendido de Esplendor sube y baja el oleaje ${ }^{430 " .}$

Pode-se afirmar que o sentido erótico de oleaje já se encontra em Pedra de Sol, pois, como se verá, este poema versa sobre o encontro amoroso e erótico. Convém acrescentar que a riqueza desta imagem se deve à sua pluralidade: representa o erotismo assim como representa o tempo. A água é uma metáfora da mobilidade, pois tanto no mar como no rio, comporta-se ao sabor dos ventos e do relevo: escoa, corre, ondula, cai, sobe, etc. Mas, quando num relevo plano e num clima calmo, permanece imóvel, como nos terrenos pantanosos onde crescem os populus, ou seja, os salgueiros e choupos, daí "choupo de água" - imagem da imobilidade, da árvore grande que

\footnotetext{
429 PAZ, Octavio. Pedra de Sol. Trad. Horácio Costa. São Paulo: Annablume, 2009. p. 7. [Negrito nosso]. 430 PAZ, Octavio. El mono gramatico. 3a ed. Barcelona: Seix Barral, 1990. p. 43.
} 
arqueia ao sabor do vento, mas se mantém na imobilidade: dupla participação, como a imagem do caracol. No mais, o vento a arquear esta árvore, crescente num ambiente úmido, pode ser compreendida como uma das aparições de Ehécatl, a divindade do vento, uma das manifestações de Quetzalcóatl.

O sabor das horas torna a busca pela felicidade incessante e, muitas vezes, malfadada tarefa, visto que esta é sempre "iminente". A natureza do instante é a de um momento que depende menos da nossa intenção e vontade para ocorrer; a sua marca é a da gestação, que envolve, muitas vezes, uma espera. Nesse limiar, as "horas de luz" são como "presságios que escorrem pelas mãos431". A espera é volátil, ansiosa, vazia. Contudo, torna-se amena à medida em que a figura de um mundo começa a surgir à frente: a imagem de mundo como a imagem do corpo. $O$ instante ainda não se configura como a experiência de tempo que conserva em seu interior a completude, mas aqui "o mundo já é visível por teu corpo,/ transparente por tua transparência432". Ora, a quem o poeta dirige a palavra? Quem é a figura que se lhe apresenta e, com isto, faz configurar uma nova imagem de mundo?

O poema se converte em caminhada: "entre galerias de sons avanço ${ }^{433 ", ~ e ~ o ~}$ poeta começa a tatear o solo que desbrava, pois vai às cegas. O mundo só se torna visível quando a partícula "tu" é enunciada em seu sentido oblíquo pela primeira vez, como no verso citado acima. Ao que o poeta reitera: "vou por teu corpo como vou pelo mundo ${ }^{434 \prime}$. A analogia entre corpo e mundo se reforça neste verso. O sentido de encarnação é um princípio ativo na poesia de Paz: tornar presente a carne, tornar presente o corpo. Neste jogo de presença e ausência, visto que estes instantes escoam, o 'eu' cede intensidade à presença, na medida em que o erotismo dá a tônica das palavras neste verso:

"teu ventre é como praça ensolarada, teus peitos dois templos onde oficia

\footnotetext{
${ }^{431}$ PAZ, Octavio. Pedra de Sol. Trad. Horácio Costa. São Paulo: Annablume, 2009. p. 9.

432 Ibidem.

433 Ibidem. p. 11.

434 Ibidem.
} 
o sangue a seus paralelos mistérios ${ }^{435 \prime}$.

A transparência, conceito que expusemos anteriormente, recebe a imagem do corpo "absorto" à luz do meio dia, sem sombras. Esta imagem-total, complementaridade oposta ao meu eu, é o "tu", a imagem por excelência da outridade, por ser aquela que pode se tornar - na poesia - o maior repositório de sentido. O "tu" é o caminho pelo qual trilham os olhos do poeta, substituídos pelas mãos, uma vez que a tatear - na conjunção carnal que se constitui - este verseja:

\footnotetext{
"vou por teu rosto como pela lua,

como a nuvem vou por teu pensamento,

vou por teu ventre como por teus sonhos ${ }^{436 "}$.
}

A aparição do tu é um processo gradual à aparição do mundo. A presença da amada constitui, neste poema, a realização de um dos princípios que, para Paz, deve ser manifesto na poesia contemporânea. Em Os signos em rotação, o mexicano, ao definir o tu como a imagem mais polimórfica não apenas da poesia, mas da arte, e ao considerar que o resultado das vanguardas destrutivas - em certa leitura do dadá - implicou na concessão do anonimato da publicidade, Paz cunha que a poesia não pode ser mais a destruição do sentido, mas sim a sua busca. Sentido que é visível pela imagem de mundo que é também imagem de tempo. Por isso, adiante, o poeta já indica onde encontra-lo: no outro. Diz Octavio Paz:

\footnotetext{
“a significação deixou de iluminar o mundo; por isso hoje temos realidade e não imagem. Giramos em torno de uma ausência e todos os nossos significados se anulam ante essa ausência. Em sua rotação o poema emite luzes que brilham e se apagam sucessivamente. O sentido desse pestanejo não é a significação última, mas é a conjunção instantânea do eu e do tu. Poema: busca do tư ${ }^{437 \prime \prime}$.
}

\footnotetext{
435 Ibidem.

436 Ibidem. p. 13.

437 PAZ, Octavio. Os Signos em Rotação. Trad. Sebastião Uchoa Leite. São Paulo: Perspectiva, 2009. p. 121.
} 
No cintilar destas luzes que acendem e se apagam, a imagem que Paz vislumbra é a da conjunção do eu no tu. Aqui, o poeta não nos diz se esta relação é erótica, mas se a compreendermos não apenas como o verbo manifesto de um poeta que constrói um poema com enormes ressonâncias temáticas nesta vereda, certamente não veremos a figura do biógrafo tampouco do crítico que buscou, na constituição de seus modelos epistemológicos, o resgate de figuras históricas em que a outridade - enquanto busca da alteridade radical - obtivesse um sentido mais amplo: o da construção de uma constelação de imagens e ideias que provém do que lhe é alheio, do que the é Outro.

Certamente, para Paz a experiência amorosa será aquela em que apreendemos o outro em sua totalidade. Por isso, Paz continua a entoar o seu trajeto:

\footnotetext{
"vou por teu corpo como por um rio, por tua forma como por um bosque, como por uma senda na montanha a terminar em repentino abismo ${ }^{438 "}$.
}

O tu, à medida em que abarca a pluralidade, nos oferece seus caminhos e descaminhos. Assim, o poeta avança também pela psique da pessoa amada. Quando amamos, nós trilhamos o pensamento do outro:

\footnotetext{
"vou por teus pensamentos perfilados

e quando passo por teu rosto branco

se derrui minha sombra espedaçada,

recolho meus fragmentos um a um,

e prossigo sem corpo, busco às cegas ${ }^{439 \prime \prime}$.
}

438 PAZ, Octavio. Pedra de Sol. Trad. Horácio Costa. São Paulo: Annablume, 2009. p. 15.

439 Ibidem. 
Novamente, no cintilar deste jogo de aparição e desaparição, o corpo se faz ausente e o poeta recorre à memória -

\author{
"salão vazio de portas abertas \\ onde apodrecem todos os verões, \\ [...] sobre sorrisos de há tantos anos ${ }^{400}$.
}

A busca do tu, em suma, é a busca do instante em que esse encontro - a conjunção entre o eu e o tu - acontece; é a busca da imagem desta obra do acaso amoroso.

Em Pedra de Sol, a alusão à importância do irromper deste instante poético no cotidiano aparece diversas vezes. Destacamos aquele em que o poeta se lança à procura dessa alteração perceptiva:

\footnotetext{
"quando passo por meu rosto procuro,

busco sem encontrar, busco um instante

uma face de tormenta e relâmpago

correndo por entre árvores noturnas,

face de chuva num jardim escuro ${ }^{441}$.
}

A coragem de se lançar nesta procura admite que todo o esforço deve ocorrer sob a pena de, ao buscar o tu, encontrar apenas o eu fragmentado, estilhaçado, na dissonância incoerente das memórias. Paz é ciente de que a busca da memória atenta, consciente, não é capaz de fazer brotar do passado as imagens que trarão o mundo de volta, pois a vivacidade da memória está presente em sua função involuntária. Nesse sentido, a busca que se põe consciente deve ter em conta que a imagem do tu é oscilante, nublada, enquanto a razão estiver operando. Este é o momento da quebra, o evento em que toda a construção da figura corporal se desvanece: a queda do eu em si mesmo, seu solipsismo. Preso à ironia da solidão, Paz diz:

\footnotetext{
440 Ibidem.

441 Ibidem.
} 


\footnotetext{
"caio com o instante, ao fundo caio,

invisível caminho sobre espelhos

que repetem minha imagem partida,

piso dias, instantes caminhados,

piso os pensamentos de minha sombra,

minha sombra piso atrás de um instante ${ }^{442 " .}$.
}

Paradoxalmente, o instante buscado é escorregadio: à medida em que íamos nos aproximando dele, somos jogados a outro instante em que vemos apenas o nosso eu. A busca do tu pressupõe um entregar-se, um esvanecimento do ego. Neste sentido, assimila-se à pratica meditativa, em que a respiração deve se sobrepor à reflexão. Mais, a busca do tu é a mesma busca pela palavra criadora. Mas o processo que subjaz aqui é, certamente, o da dialética da solidão e comunhão.

Em O Labirinto da Solidão, no apêndice intitulado Dialética da Solidão, Paz diz:

\begin{abstract}
"a solidão é o substrato último da condição humana. O homem é o único ser que se sente sozinho, o único que é busca de outro. [...] O homem é nostalgia e busca de comunhão. Por isso, toda vez que sente a si mesmo, sente-se como carência do outro ${ }^{443 \prime \prime}$.
\end{abstract}

A queda em si é, pois, a consciência do poeta de sua própria solidão. Sua busca deverá ser a superação de nossa própria condição original. Paz a estabelece como original, pois, para ele, a busca pelo outro é a nossa tentativa de aplacar a mácula deixada em nós no instante em que deixamos a vida uterina, onde "uno com o mundo, o feto é vida pura e em estado bruto, um fluir ignorante de $\mathrm{si}^{444 "}$. Nascer é, portanto, o primeiro instante da

\footnotetext{
442 Ibidem. p. 17.

443 PAZ, Octavio. O Labirinto da Solidão. Trad. Ari Roitman. Paulina Wacht. São Paulo: Cosac Naify, 2014. p. 189.

444 Ibidem.
} 
Queda. Tal como Adão, jamais retornamos ao Paraíso perdido. Ou, poderíamos nos questionar: exceto se formos capazes de, como afirma Marcel Raymond,

\footnotetext{
"encontrar novamente o "estado natural", que era, em suma, esta esperança senão a consequência de um sonho ancestral semimergulhado no inconsciente, o sonho de um universo mágico, em que o homem não se sentiria separado das coisas, em que o espírito reinaria sem intermediário sobre os fenômenos, fora de qualquer caminho racional? ${ }^{445 \prime}$
}

O que as obras ensaísticas de Paz nos mostraram é que esta centelha talvez possa ser encontrada no seio da própria razão, ao compreendê-la em sua natureza plural, multifacetada e analógica. Portanto, se a solidão é condição universal, a existência do outro é participativa desta condição. Em Águia ou Sol, Octavio Paz inverte o pressuposto cartesiano, a certeza indubitável do cogito ergo sum, pelo ponto arquimediano diante do qual se constrói todo nosso eu: o outro. Nesta obra, ele diz que "então pois, existe a poesia, o amor existe. E se eu não existo, existes $t^{446 "}$ " O "tu" é transcendente, ele não depende de minha estrutura subjetiva para ser. Neste sentido, a crença na alteridade radical é a afirmação de sua resistência ao enclaustro solitário do ser humano moderno: "por todas as partes os solitários forçados começam a criar as palavras do novo diálogo 447". Invés de "penso, logo existo": és, logo existo. O eu ao depestar do tu.

Após a queda, Paz confessa o que e a quem busca: "busco uma data viva como um pássaro ${ }^{448 " . ~ E s t a ~ b u s c a ~ s o ́ ~ l o g r a r a ́ ~ e ̂ x i t o ~ c a s o ~ o ~ p o e t a ~ s a i b a ~ s e ~ d e s p r e n d e r ~ d o ~ q u e ~}$ imobiliza o fluxo das imagens e da memória. Semelhante dilema também aparece em Águia ou Sol, quando Paz a ele responde:

\footnotetext{
“atreves-te a dizer Não, para um dia poderes dizer melhor Sim. Esvazia teu ser de tudo o que os outros o encheram: grandes e pequenos nadas, todos os nadas
}

\footnotetext{
445 RAYMOND, Marcel. De Baudelaire ao Surrealismo. Trad. Fúlvia M. L. Moretto; Guacira Marcondes Machado. São Paulo: Edusp, 1997. p. 14.

${ }^{446}$ PAZ, Octavio. Águia ou Sol. Trad. Horácio Costa. México: Fondo de Cultura Económica, 2001. p. 159.

447 Ibidem.

${ }^{448}$ PAZ, Octavio. Pedra de Sol. Trad. Horácio Costa. São Paulo: Annablume, 2009. p. 17.
} 
de que está feito o mundo dos outros. E depois, esvazia-te de ti mesmo, porque tu - o que chamamos eu ou pessoa - também é imagem, também é outro, também é nada. Esvaziado, limpo do nada purulento do eu, vazio de tua imagem, já não és mais do que espera e aguardar. Vêm as eras de silêncio, eras de seca e de pedra. Às vezes, numa tarde cualquer, cai uma Palavra, que se pousa levemente sobre essa terra sem passado ${ }^{449 \prime \prime}$.

O ser humano é busca, mas a busca pressupõe a espera. Por isso, tanto o processo poético como o encontro amoroso dependem desta condição, que exige virtuosa paciência. Contudo, esta sabedoria residente na espera é algo que talha o poeta como uma propedêutica: ensina-o a viver para saber morrer, ensina-o a aguardar o retorno em voo da palavra que pousará com a precisão de uma águia. O poeta que vislumbra o instante poético vê nesta parelha um todo não-contraditório. Em A Dialética da Solidão, Paz diz que embora nada saibamos acerca da fundamental natureza da vida e da morte, "todo nosso ser aspira a escapar desses opostos que nos dilaceram ${ }^{450 "}$.

No interior deste esforço de memória, Paz consegue reaver imagens que the foram marcantes à juventude e que, como se verá, permanecerão impressas em seu espírito tal qual um carimbo permanente. Trata-se do antigo Colégio de San Ildefonso, depositário das memórias de juventude de Paz:

\footnotetext{
"busco o sol das cinco da tarde em ponto

pelos muros de tezontle amornado:

a hora sazonava seus racimos

e ao abrir-se escapavam-se as meninas

de sua entranha rósea e se espalhavam

pelos pátios de pedra do colégio $451 "$.
}

\footnotetext{
449 PAZ, Octavio. Águia ou Sol. Trad. Horácio Costa. México: Fondo de Cultura Económica, 2001. p. 21. 450 PAZ, Octavio. O Labirinto da Solidão. Trad. Ari Roitman. Paulina Wacht. São Paulo: Cosac Naify, 2014. p. 190.

451 PAZ, Octavio. Pedra de Sol. Trad. Horácio Costa. São Paulo: Annablume, 2009. p. 17.
} 
Os muros de tezontle, de característica avermelhada, dividem espaço com as colunas de granito que sustentam as "três ordens superpostas". Em seu esforço de memória, Paz procura vislumbrar quem é a mulher que o acompanhava neste espaço: "alta como o outono ela caminhava/ envolvida pela luz sob a arcada452". O que se sabe dela é que era adolescente: talvez, os primeiros arroubos de amor que sentira o poeta? Contudo, o esforço de memória o faz perpassar a figura da mulher universal: todas e nenhuma. Paz diz, novamente em versos que nos remetem a Artêmis:

\author{
"teu nome não me lembro, Melusina, \\ Laura, Isabel, Perséfone, Maria, \\ são teus os rostos todos e nenhuma ${ }^{453 "}$.
}

Preso a este dia, do qual tenta se lembrar, o poeta ainda se encontra deslocado, porém não completamente, uma vez que o espaço onde sua memória - ou a vívida imagem do mito - o situa é reanimado pela presença amada. Segundo Giraud, nestes versos,

\footnotetext{
"a favor de uma anfibologia similar encontrada nos versos de Nerval, o verbo caminaba reenvia, pelo sentido, à mulher, mas pela gramática, à hora. A hora encarna, portanto, nesta rapariga, cujos passos fazem ressurgir no fundo da memória um espaço olvidado ${ }^{454 \prime \prime}$.
}

O retorno do Colégio de San Ildefonso, no entanto, estanca diante da petrificada imagem da mulher arquetípica, imóvel, apesar de reluzente. Ainda segundo Giraud, nesta passagem se encerra a primeira parte da obra - se é licito dividir um poema "contínuo e perpétuo" como Pedra de Sol - em que "a fé nervalina no eterno feminino escorre nas fórmulas reiterativas de uma doxologia ${ }^{455 " . ~ A ~ s a b e r, ~ n o s ~ v e r s o s: ~}$

\footnotetext{
452 Ibidem.

453 Ibidem. p. 19.

454 GIRAUD, Paul Henri. Octavio Paz: caminho para a transparência. Trad. António Teixeira. Lisboa: Instituto Piaget, 2002. p. 249.

455 Ibidem. p. 251.
} 


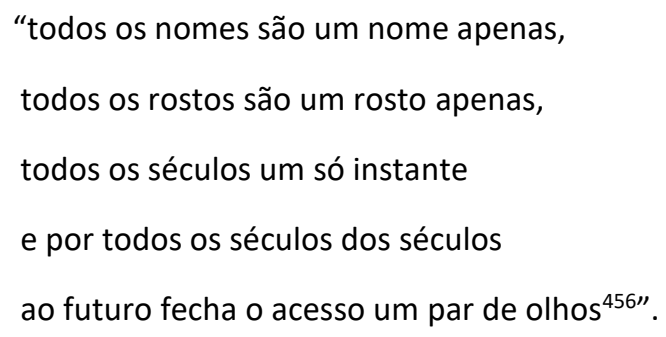

O instante buscado se impõe como a única realidade possível: o par de olhos nos impede de nos distrairmos ou desviarmos os olhos, tamanha atração da memória, tamanha imersão no instante.

Ao mesmo tempo, Paz continua a dar mostras de que a busca por este instante poético em Pedra de Sol se contrapõe ao tempo reificado, ao tempo da jornada de trabalho, escamoteado e alienado no ramerrão cotidiano, sobre o qual nossos sentidos são incapazes de aferir qualquer sentido:

\footnotetext{
“enquanto lá fora dispara o tempo

e o mundo com seu carniceiro horário

golpeia e invade as portas de minha alma ${ }^{457 \prime \prime}$.
}

É importante destacar que o imbricamento entre história e mito se deve à compreensão que Paz possui da história enquanto algo vivo. Em O conceito de tempo, o filósofo alemão Martin Heidegger a define assim: "Sólo el "cómo" puede reiterarse. El pasado, experimentado como historicidad propia, es todo menos lo que se fue. Más bien, es algo a lo que puedo volver una y otra vez ${ }^{458 "}$. Acerca desta compreensão da História como obra aberta, é possível verificar na obra poética de Paz a representação desta postura de forma clara. Em Águia ou Sol, no poema prosaico Em Direção ao Poema, o poeta diz que, espontaneamente, "quando a História dorme, fala em sonhos: na testa do povo

\footnotetext{
${ }^{456}$ PAZ, Octavio. Pedra de Sol. Trad. Horácio Costa. São Paulo: Annablume, 2009. p. 23.

457 Ibidem.

458 HEIDEGGER, Martin. El concepto de tiempo. Trad. Raúl Gabás Pallás y Jesús Adrian Escudero. Madrid:

Ed. Trotta, 2006. Pag. 56.
} 
adormecido o poema é uma constelação de sangue. Quando a História acorda, a imagem faz-se ato, acontece o poema: a poesia entra em ação ${ }^{459 \prime \prime}$. Paz também parece assumir tal princípio em Pedra de Sol, pois, no interior do instante poético, nós podemos vislumbrar toda miríade histórica:

\author{
"oh vida por viver e já vivida \\ tempo que em marulhos surdos retorna \\ e vai embora sem voltar o rosto, \\ o que passou não foi mas está sendo \\ e silenciosamente desemboca \\ num outro instante que desaparece ${ }^{460 \prime \prime}$.
}

Isto posto, como pode o instante poético abarcar uma temporalidade como a mítica num mundo que é consequência dos desdobramentos da imagem de tempo teleológicalinear-progressiva da modernidade e da cristandade?

Em primeiro lugar, para Roland Barthes há uma diferença entre o discurso mítico e o discurso poético. Para ele,

\footnotetext{
"enquanto o mito visa a uma ultrasignificação, a ampliação de um sistema primeiro, a poesia, pelo contrário, tenta recuperar uma infra-significação, um estado pré-semiológico da linguagem; em suma, esforça-se por retransformar o signo em sentido; o seu ideal [...] seria atingir não o sentido das palavras, mas o sentido das próprias coisas ${ }^{461 "}$
}

Paz alude a esta função quando chama, em O Arco e a Lira, a palavra poética de palavra de fundação, capaz de instaurar um ritmo, uma imagem e uma transfiguração do tempo, em suma, sentido. No mais, quando se vale do mito na poesia, podemos afirmar que Paz

\footnotetext{
459 PAZ, Octavio. Águia ou Sol. Trad. Horácio Costa. México: Fondo de Cultura Económica, 2001. p. 161.

460 PAZ, Octavio. Pedra de Sol. Trad. Horácio Costa. São Paulo: Annablume, 2009. Pag. 27.

461 BARTHES, Roland. Mitologias. Trad. Rita Buongermino, Pedro de Souza e Rejane Janowitzer. Rio de Janeiro: DIFEL, 2006. Pag. 225.
} 
o incorpora no sentido de transformar as próprias coisas, ou seja, de fazer com que o mito receba o sentido de sua própria poesia: a isto podemos chamar atualização do mito. Não se trata, portanto, de inseri-lo anacronicamente ou de fazer a vista do historiador no discurso, nem de realizar o trabalho do mitólogo, estabelecendo um discurso interpretativo de terceira ordem que, assumindo a pretensão de atingir as coisas mesmas, colará no mito o que seria a sua versão interpretativa atualizada. Ainda que possamos dizer que, no trabalho de mitólogo que Paz empreende em outras obras, ele transfigurara o próprio mito em outra coisa - ou seja, nas palavras de Barthes: “Visto

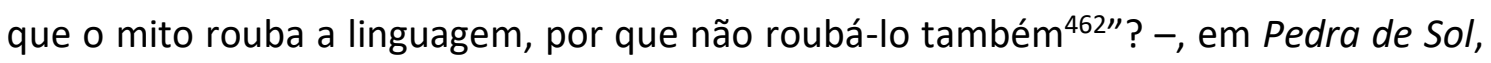
o papel do mito é o de oferecer o tecido por meio do qual o poeta despertará para outra coisa: o amor. Invés da fatalidade da temporalidade mítica, diante da qual a vontade humana nada pode fronte às potências divinas, o instante amoroso rompe este tecido como uma instauração da liberdade.

Para Octavio Paz, a liberdade deve ser um pressuposto da relação amorosa. Em Águia ou Sol, no mesmo poema que citamos anteriormente, temos os seguintes versos: "o poema prepara uma ordem amorosa. Prevejo um homem-sol e uma mulher-lua, aquele livre de seu poder, esta livre de sua escravidão, e amores implacáveis riscando o espaço negro. Tudo cederá a estas águias incandescentes ${ }^{463 " . ~ E s t a ~ n o v a ~ c o n j u n c ̧ a ̃ o ~}$ erótica parece a superação pela dialética da relação senhor-escravo tal como postulado por Hegel, onde a síntese da liberdade repousa na relação que beneficie seus dois polos dialéticos, no caso, o homem e a mulher. A tipificação do amor como ato de escolha fundamentado na liberdade também aparece em Sor Juana Inés de la Cruz ou as Armadilhas da Fé. Na biografia da monja, Paz considera que os poetas são responsáveis pelo descobrimento da liberdade da pessoa amada. Em seu raciocínio, ele afirma que se

\footnotetext{
“para Platão, a pessoa amada ou até mesmo a forma mais elevada, é um objeto de prazer ou de contemplação espiritual; para Catulo e Propércio, a pessoa amada é antes de tudo uma liberdade, um ser humano com o qual
}

\footnotetext{
462 Ibidem. Pag. 227.

463 PAZ, Octavio. Águia ou Sol. Trad. Horácio Costa. México: Fondo de Cultura Económica, 2001. p. 161.
} 
estabelecemos uma relação difícil e na qual nossa liberdade também se exercita e se compromete ${ }^{464 "}$.

A diferença da visão platônica para a poética é, basicamente, a de uma relação de conhecimento para uma de reconhecimento. Seria gratuito dizer que a segunda se caracteriza de uma forma proximal à outridade, uma vez que esta é o reconhecimento do outro como ser único e cujo valor é imensurável. Este reconhecimento é o da pessoa amada enquanto sujeito, isto é, possuidora do livre-arbítrio. Para Paz, a Antiguidade nos legou esta dupla visão do amor, construída a partir do erotismo e do amor intelectual, onde amamos não apenas o corpo, mas a alma da pessoa amada, em suma, seus caminhos de pensamento.

Além disso, Paz considera que Catulo foi capaz de vislumbrar um dos problemas que, em sua opinião, mais nos assombram: o fato de o amor ser uma "estranha

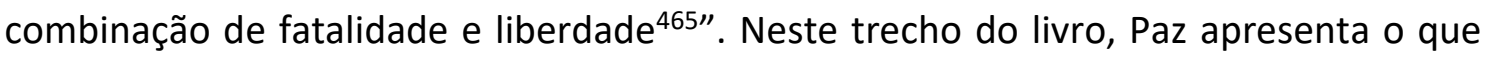
acima chamamos "conjunção entre eu e tu". Trata-se do resultado dialético da escolha erótica, isto é, em que, diante dos dois polos diametralmente opostos, "o amor se propõe um impossível, mas esse impossível é a condição do amor: fazer do você um eu e, do eu, um vocêt ${ }^{466 " . ~ A l e ́ m ~ d i s s o, ~ a o ~ p e n s a r ~ a c e r c a ~ d a ~ l i n g u a g e m ~ e r o ́ t i c a ~ e ~ d o s ~ s i g n o s ~}$ corpóreos presentes na poesia cristã, Paz afirma que a influência neoplatônica é visível. Entretanto, ao adotar Platão, o cristianismo dele resguardou o corpo, não o condenando de todo, destarte a culpabilidade imanente à própria carne. Ainda assim, para Paz, o corpo não perde sua imagem,

\footnotetext{
"como o demonstram, por exemplo, a doutrina da ressureição de carne e a do "corpo glorioso". O misticismo cristão, embora derivado do platônico, encontrou na poesia erótico-profana uma mina de imagens e associações. A leitura do Cântico dos Cânticos como um texto místico seria impossível se o
}

\footnotetext{
${ }^{464}$ PAZ, Octavio. Sor Juana Inés de la Cruz ou As armadilhas da fé. Trad. Wladir Dupont. São Paulo: Ubu Editora, 2017. p. 120.

465 Ibidem.

${ }^{466}$ Ibidem. p. 121.
} 
cristianismo, ao contrário do platonismo, não fosse uma religião de encarnação ${ }^{467 ” \prime}$.

Ainda que Sor Juana, em seus textos, confessasse uma visão do amor perfeito como sendo o da autossuficiência divina, onde "amar sem procurar reciprocidade é um heroísmo que não é humano, mas divino ${ }^{468 "}$, a origem de seus sentimentos - presentes em sua poesia - vem das práticas e vivências da vida na corte e de sua leitura dos trovadores clássicos. Mas, na visão de Juana Inés, o amor autossuficiente não deveria ser atributo apenas da divindade, mas também da criatura, pois a poeta reconhece a mácula que nos compõe e, por percebê-la tão vivamente, a vivencia de maneira culposa. Eis, pois, o que expressam os versos:

\footnotetext{
“Tan precisa es la apetencia que a ser amados tenemos, que, aun sabiendo que no sirve, nunca desarla sabemos ${ }^{469 \prime \prime}$.
}

Paz reconhece o movimento da dialética entre a fatalidade e liberdade no desejo de amar bem como no desejo de ser amado.

Ao percorrermos o poema, a figura da Pedra retorna e faz do próprio retorno a sua marca. Ao se sentir arder (pelas chamas do Sol?), Paz busca pela água, mas não a encontra. O único elemento, que se torna onipresente, é a pedra:

\footnotetext{
“ardo sem consumir-me, busco a água

e teus olhos são de pedra, não há água,

e teu peito, teu ventre, tuas ancas

são de pedra, e a pó sabe tua boca,

tua boca sabe a pó envenenado,
}

\footnotetext{
467 Ibidem. p. 348.

468 Ibidem. p. 350

469 Ibidem. p. 349.
} 
teu corpo sabe a poço sem saída,

passadiço de espelhos que repetem

os olhos do sedente, passadiço

que ao ponto de partida chega sempre ${ }^{470 "}$.

O retorno ao ponto de partida, novamente, demarca a estrutura circular do marcador temporal asteca, a própria Pedra. A concatenação das imagens presentes nestes versos, a saber, a água, a pedra, o espelho, o pó, reforçam-se no jogo de aliterações e repetições das mesmas palavras, como água, pedra, boca e passadiço. Podemos interpretar a água buscada pelo poeta de duas maneiras: a primeira, em que ela é a única coisa que poderia vir a aplacar a sua sede; e a segunda, em que a água é análoga à própria palavra, visto que a sede do poeta é a sede de dizer algo, uma sede indistinta do sentir. Já afirmamos que a imagem da água representa, tradicionalmente, o movimento. Contraposta à pedra, que representa a imobilidade, a persistência da água é capaz de transformá-la em outra coisa, tal como já afirma o ditado popular "água mole em pedra dura tanto bate até que fura". Contudo, a sede do poeta é também uma sede conjunta à dor da ferida aberta, cuja lavagem se faz necessária. Mas este afirma, embotado de pedra e terra, que não há água. Adiante, Paz ainda dirá que a presença da ferida é total:

\footnotetext{
“Nada há em mim além desta ferida, uma oquidão que mais ninguém frequenta, presente sem deságue, pensamento ${ }^{471 "}$.
}

A nosso ver, esta ferida, diferentemente da sede - apesar de lhe ser correlata - é a própria solidão. Ao se sentir o oco, o poeta tem necessidade de ser preenchido. A volubilidade da palavra pode fazê-lo, pois o ritmo da poesia flui como o movimento rítmico da água, mas o que pode preencher a lacuna aberta na pele, a mácula exposta, é apenas a figura do outro. As únicas formas de aplacar a dor da ferida e a sede da boca

\footnotetext{
470 PAZ, Octavio. Pedra de Sol. Trad. Horácio Costa. São Paulo: Annablume, 2009. Pag. 27.

471 Ibidem. p. 29.
} 
são o amor e a poesia. Somente estas experiências são capazes de inserir o ser humano na manifestação real da temporalidade.

Em A Dialética da Solidão, Paz diz que o tempo do mito, apesar de fundar contínuos estanques, repetitivos, nos possibilitava uma experiência do fluir temporal mais pura. Em nossa época, nos tornamos prisioneiros do relógio que, por sua vez, também passou a dominar os calendários. Para ele,

\footnotetext{
"houve um tempo em que o tempo não era sucessão e passagem, mas fluir contínuo de um presente fixo, no qual estavam contidos todos os tempos, o passado e o futuro. O homem separado dessa eternidade em que todos os tempos são um, caiu no tempo cronológico [...]. Pois no momento em que o tempo se divide em ontem, hoje e amanhã, em horas, minutos e segundos, o homem deixa de ser uno com o tempo, deixa de coincidir com o fluir da realidade. Quando digo "neste instante", o instante já passou. A mediação espacial do tempo tira o homem da realidade, que é um presente contínuo, e transforma em fantasmas todas as presenças em que a realidade se manifesta, como ensina Bergson ${ }^{472 "}$.
}

Ao citar Bergson, Octavio Paz nos apresenta um pensador para quem nossa correlação com o tempo é a da convergência e coincidência de ritmos. A preocupação de Bergson é oferecer um pensar que aproxime o sujeito dos dados imediatos da consciência, os quais, por sua vez, encontram-se no fluir temporal que é a duração. Para que isso seja possível, é necessário um aprofundamento no próprio tempo, completamente diverso à maneira que realizamos o afastamento deste enquanto realidade objetiva de investigação conceitual. Se o tempo é dado imediato, não podemos analisá-lo superficialmente, pois o maquinismo teórico-conceitual não pode dar conta de algo que, por sua natureza, extrapola os recortes limítrofes da nossa inteligência. Será neste ponto, portanto, que o autor recorre à intuição como forma de penetrar a fundo a realidade humana.

472 PAZ, Octavio. O Labirinto da Solidão. Trad. Ari Roitman, Paulina Wacht. São Paulo: Cosac Naify, 2014. p. 202. 
Neste sentido, o paralelo traçado entre Octavio Paz e Walter Benjamin acerca da continuidade do passado no presente pode também ser estendido a Henri Bergson, não apenas pela operacionalidade das imagens na construção do pensamento, mas pela perspectiva confluente dos dois termos temporais. Para Saúl Jimenez-Sandoval, em Love, Memory and Being in Octavio Paz's Piedra de Sol,

\begin{abstract}
"modern society establishes that the past is no longer a living force, and that it has been eradicated even from memory, though in Bergson and Paz we witness the extensive survival of the past because the being who fully inhabits the present is able to access Being itself - an enlightened state of consciousness that includes all the personal and collective archives of the past. The present, however, is not complete; rather, it is pure becoming, as it is existence fixed or completely knowable, for it is not constituted by being, but through activity and usefulness. The past, on the other hand, is perceived by capitalist society as useless, inactive, and impassive because it can no longer materialize a mode of production that will generate capital. Yet in Bergson and Paz, the past in coexistence with the present is, in the full sense of the word: it is identical with being itself. [...] In this regard, Paz's poetry and Bergson's philosophy affirm life, time, and the present that is eternal in this consciousness of the past and its vision for the future" ${ }^{\prime 473}$.
\end{abstract}

Jimenez-Sandoval reforça a ideia de que tempo presente é marcado pela incompletude e esta carência o coloca num estado de constante vir a ser. Para o crítico, em Octavio Paz há esta constante reafirmação do devir na existência, devir que é movido, constantemente, por um passado que, fruto do tempo em constante movimento, é inacabado. Ademais, haveria uma total identificação entre o processo que une presente e passado ao movimento - temporal - do próprio Ser. No entanto, ainda que esta concepção de tempo como Duração pudesse vigorar na compreensão do tempo em seu sentido rítmico em Paz, é necessário vislumbrar que o tempo também é imagem e, por conta disso, também é fruto inter-relacional da sociedade e produção histórica. Graças a esta concepção, Paz defende que o tempo é plural: passível de ser vivido de várias

\footnotetext{
473 JIMENEZ-SANDOVAL, Saúl. Love, Memory and Being in Octavio Paz's Piedra de Sol In CANTU, R. The willow and the spiral. Newcastle: Cambrigde Scholars Publishing. 2014. p. 191.
} 
formas, em instantes complexos, posto que realizáveis na linha tortuosa da história. Podemos afirmar, portanto, que Paz coaduna com a crítica de Bergson acerca da dimensão espacializada (portanto, redutiva) do tempo, ao toma-lo como imagem, mas, assim como Walter Benjamin, não o abstrai de sua dimensão histórica.

Para que possamos compreender como Henri Bergson constrói sua crítica acerca da noção de tempo espacializado, é preciso compreender, primeiramente, como opera o entendimento e a inteligência. A formação da inteligência humana, para Bergson, em sua gênese, esteve sempre ligada à busca da ação possível. Com isso, o filósofo quer dizer que as representações construídas pela nossa mente são representações que só são possíveis pois foram selecionadas por uma percepção que visava agir e manipular o seu entorno, tal qual um tatear num quarto escuro que busca conseguir representar mentalmente o local e a distância de cada objeto em nosso caminho. Lidamos com estas representações tal como lidamos com as imagens do mundo que nos circunda. Além disso, Bergson afirma, em Matéria e Memória (1999): “Chamo de matéria o conjunto das imagens, e de percepção da matéria essas mesmas imagens relacionadas à ação

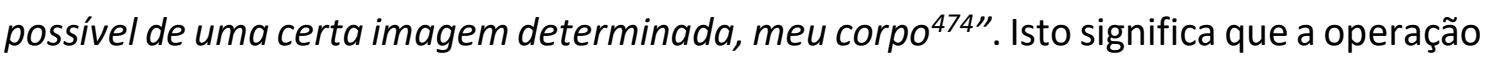
que nossa percepção realiza sobre o mundo material (compreendido como conjunto de imagens) é uma operação ativa. Daí nossa inteligência, por consequência, possuir um caráter que é utilitário. Ademais, não há em Bergson uma oposição radical entre a experiência e a razão, apesar de podermos ressaltar que a experiência, marcada pelas representações que povoam nossa mente, afasta-se de um contato direto com a vivência do real. A possibilidade desta vivência mais imediata, aliás, é uma das questões que Bergson trabalha em sua obra: como perceber o mundo sem os intermediários da razão que a recortam? Por conta disso, há uma inversão do percurso da tradição filosófica, marcadamente orientada para seguir não dos dados imediatos dos sentidos à problematização, mas da problematização dada previamente aos dados imediatos que a ela foram "moldados". Ou seja, parte-se das problematizações previamente construídas em busca destes dados sensíveis (numa experiência pré-reflexiva), cujo conteúdo foi deformado num processo de adaptação determinado pelo entendimento

\footnotetext{
${ }^{474}$ BERGSON, Henri. Matéria e Memória: ensaio sobre a relação do corpo com o espírito. Trad. Paulo Neves. São Paulo: Martins Fontes, 1999. p. 17.
} 
e pela inteligência. Graças a esta manipulação do real, a preocupação de Bergson é de se constituir um saber sobre o tempo que seja expressivo e que não implique na supressão da experiência originária dos dados imediatos da consciência. Trata-se de considerar o dado embotado pelo invólucro conceitual como nulo ao conhecimento. $\mathrm{O}$ dado bruto, puro, deve ter o seu valor enquanto partícula móvel da realidade compreensível.

Sobre a percepção, o que a depura e a afasta da experiência imediata é basicamente a memória. É graças à memória (que introjeta progressivamente o passado atuante no presente, tal qual a figura de um cone que perfura a superfície do real) que o espírito se distingue da matéria que, se tomada por si sem o peso das lembranças, não se distinguiria da própria matéria. Nestes termos, podemos afirmar que há em Bergson um empirismo radical, que nos permite assimilar a matéria ao espírito, enquanto orientados pela percepção pura. Mas, como funcionará, então, o processo de distinção? Segundo Bergson, "a distinção do corpo e do espirito não deve ser estabelecida em

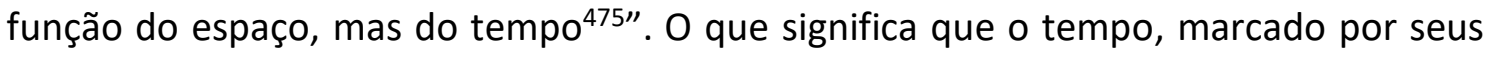
diferentes ritmos de duração, deve ser o critério que sustenta a crítica à concepção dualista de corpo e alma. Isso explica porque nossa percepção das coisas não é total. Além do mais, "perceber todas as influências de todos os pontos de todos os corpos

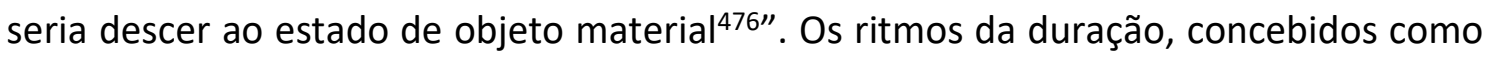
diversos, podem variar no que tange à matéria e ao espírito. Será nossa educação dos sentidos, da qual participará a memória, que conferirá continuidade a percepções difusas e aparentemente desordenadas. Porém, existe um procedimento que permite que estes possam estar afins um ao outro, ou seja, que possamos, em nosso saber, estarmos no mesmo ritmo duracional que aquilo que visamos conhecer. Trata-se da noção de simpatia.

Convém acrescentar que, para Bergson, nesse processo deformador de que se vale nossa percepção respaldada pela memória não há lugar para o instantâneo, pois "naquilo que chamamos por esse nome existe já um trabalho da nossa consciência, que prolonga uns nos outros, de maneira a captá-los numa intuição relativamente simples,

\footnotetext{
475 Ibidem. p. 259.

476 Ibidem. p. 49.
} 
momentos tão numerosos quanto os de um tempo indefinidamente divisível ${ }^{477 "}$. Não há, portanto, para o autor, no nosso processo de conhecimento prático, uma visão instantânea do real, ainda que nossos recortes intelectuais possam nos fazer crer nesta realidade. Esta crítica ao instante, para Bergson, contudo, vale apenas para a sua concepção espacializada. A concepção apresentada e compreendida por Octavio Paz é a do tempo em que os ritmos da duração se apresentam, descontinuamente à História, num regime de continuidade ao próprio ritmo de Duração do Ser. Por isso, à continuidade da Durée bergsoniana assimila-se a experiência do presente que se apresenta no momento em que irrompe o instante paziano.

Não que a memória se reduza a apenas uma única função, a de introduzir opções práticas de ação possível no tempo presente, uma vez que, para Bergson, a memória possui duas faces: a memória-lembrança e a memória-hábito. Mas, enquanto uma se limita à finalidade prática, a outra prende-se ao inútil e, invés de representar o passado como determinante ao futuro, encena uma imagem que é passível de comparação ao que se passa durante o sonho ou durante o devaneio. A imagem-lembrança é espontânea. Assim, a inteligência humana possui em si um viés generalista, muito prático do ponto de vista da eficiência e da ação. Podemos afirmar que a inteligência está posta no ritmo da necessidade. Quando Bergson analisa o "discernimento" humano, em Matéria e Memória, dirá que possuímos uma visão fotográfica ${ }^{478}$ das coisas: é assim que procede nosso órgão perceptivo. Em A Evolução Criadora (2001), Bergson dirá se tratar de um procedimento cinematográfico, pois, a seu ver, a construção do nosso conhecimento se dá de forma prática, pois é

\footnotetext{
"concentrada naquilo que se repete, unicamente preocupada em ligar o mesmo ao mesmo, a inteligência volta as costas à visão do tempo. Repugna-lhe o fluente, e solidifica tudo aquilo em que toca. Não pensamos o tempo real. Mas vivemo-lo, porque a vida transcende a inteligência ${ }^{479 "}$.
}

\footnotetext{
477 Ibidem. p. 73.

478 Ibidem. p. 36.

${ }^{479}$ BERGSON, Henri. A Evolução Criadora. Trad. Pedro Elói Duarte. Lisboa: Edições 70, 2001. p. 51.
} 
O que a torna "cinematográfica" é que estas fotografias tiradas e reconhecidas pela nossa percepção procedem segundo as características funcionais da nossa memória. 0 ato de tirar uma fotografia é, praticamente, estancar por um instante o movimento que está em fluxo. Adiante, nesta mesma obra, Bergson dirá que

\footnotetext{
"tiramos fotografias da realidade que passa, e, como elas são características dessa realidade, basta-nos fazê-las desfilar ao longo de um devir abstrato, uniforme, invisível, situado no fundo do aparelho do conhecimento, para imitar o que há de característico nesse mesmo devir. Percepção, intelecção e linguagem procedem geralmente assim. Quer se trate de pensar o devir, ou de exprimi-lo, ou mesmo de percebê-lo, não fazemos mais do que acionar uma espécie de cinematógrafo interior ${ }^{480 \prime}$.
}

Em resumo, mesmo quando nosso conhecimento intelectual parece se aproximar da duração móvel da realidade, ele o faz através de componentes fixos, estáveis, como estas "fotografias" da nossa percepção, que não se distinguem de recortes espacializados que fazemos no complexo contínuo no qual estamos inseridos. Isso se deve ao fato de nossa linguagem, nosso discurso e as palavras conceituais de que dispomos operarem segundo elementos que se vinculam à necessidade prática.

Dessa forma, podemos considerar, no que tange à nossa representação tradicional do tempo, que estas fotografias são estancadas como "instantes" fixos, segundo a concepção tradicional de espaço. Eis, pois, nossa forma de conhecer segundo os instrumentos da nossa inteligência. Ele, o instante pontual, se assimila à forma. Que seria, então, o tempo que as ciências naturais, como a física, consideram em seu escopo teórico? Para Bergson, trata-se de um conjunto de simultaneidades, compostas por essa multiplicidade de instantes regularmente selecionados pela nossa inteligência funcional. Daí a dimensão cronológica que, de forma similar, tanto crítica Octavio Paz. Ao nos tornarmos prisioneiros do relógio, submetemos o tempo a esta operação epistemológica de escamoteamento.

480 Ibidem. p. 271. 
Por isso, a nosso ver, é impossível não compreender que a defesa que Octavio Paz faz do instante poético e qualitativo resulta de uma crítica epistemológica à nossa forma de compreender o tempo e a história. Pensar um fenômeno criativamente abrupto e inconstante, por ser inovador a si próprio, como a vida, derrapa em dificuldades se nos atermos e nos limitarmos a essa concepção estanque do tempo. Se o tempo é invenção, como abstraí-lo em um signo que lhe atribui a mesma natureza que atribui ao espaço? Bergson responde assertivamente ao afirmar que "o tempo ou é

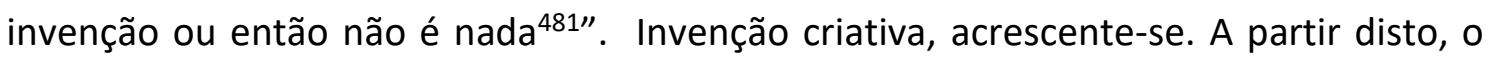
francês retomará a tradição filosófica clássica, por nós herdada, para apresentar onde está assentado o erro na nossa concepção antiga de tempo enquanto abstração espacializada. Aristóteles e Platão pensaram, ambos, modelos temporais que se relacionavam, distintamente, à eternidade. Realizar a crítica a ambos os autores é, por sua vez, realizar uma crítica à noção de eterno que durante muito permeou a cultura ocidental e que, para o autor, deixou seus vestígios na ciência e nas epistemologias modernas. Contudo, tais apreciações do tempo conservam algo da intuição originária que pode ser atribuída ao nosso contato com os dados imediatos. Por exemplo, para Platão, o tempo (imagem móvel da eternidade) por ser uma marca da privação e da imperfeição da realidade sensível que transcorre e se transforma, ou seja, em sua concepção, conserva algo de mutável. Seu erro, na concepção bergsoniana, foi presumir que a verdadeira essência da realidade, o mundo ideal, fosse marcado pela eternidade, este presente que não se vincula a nenhum tipo de fluxo possível (passado ou futuro).

Já em relação à concepção aristotélica apresenta uma noção primordial de instante, submetida a uma concepção cíclica do tempo que, assim como as Formas em Platão, é uma representação perfeita do eterno. Apesar de distinto, o procedimento de Aristóteles não consegue evitar o incontornável desaguar de uma concepção estaque de tempo submetida a um conceito fixo, pois

\footnotetext{
"igualmente, tendo-se começado por recusar às Ideias uma existência independente, e não podendo, porém, privá-las disso, Aristóteles pressionou-
}

481 Ibidem. p. 301. 
as umas contra as outras, reuniu-as numa bola, e colocou acima do mundo físico uma Forma que seria assim a Forma das Formas, a Ideia das Ideias, ou, enfim, para empregar a sua expressão, o Pensamento do Pensamento. Este é o Deus de Aristóteles - necessariamente imutável e estranho ao que se passa no mundo, porque não é senão a síntese de todos os conceitos num único conceito $^{482 " \prime}$.

A concepção aristotélica presume, portanto, um continuum, mas que é, porém, pontual, infinito e quantificado. Divide-se como movimento entre o antes e o depois. Para Giorgio Agamben, a continuidade desse tempo aristotélico é garantida pela divisão em instantes (tò nyn, o agora) inextensos e análogos ao ponto geométrico. Em Tempo e História: crítica do instante contínuo, o italiano afirma que

\footnotetext{
"o instante, em si, nada mais é que a continuidade do tempo (synécheia chrónou), um puro limite que conjugue e, simultaneamente, divide o passado e o futuro. Como tal, ele é algo que não pode ser aferrado, cujo paradoxal caráter nulificado é expresso por Aristóteles na afirmação de que o instante é sempre "outro", na medida em que divide o tempo ao infinito, e, contudo, sempre o mesmo, na medida em que une o porvir e o passado garantindo a sua continuidade; e esta sua natureza é o fundamento da radical "alteridade" do tempo e do seu caráter destrutivo ${ }^{483 \prime \prime}$.
}

Em suma, a espacialização do tempo, segundo a concepção aristotélica, reside na noção de instante enquanto ponto geométrico e homogêneo. O ponto geométrico é incapaz de apresentar, em seu interior, uma matriz qualitativa. Isso refletirá sobre toda a concepção filosófica ocidental posterior. Ou seja, "a incapacidade do homem ocidental de dominar o tempo tem o seu primeiro fundamento nesta concepção grega do tempo como um continuum quantificado e infinito de instantes pontuais em fuga ${ }^{484 \prime}$. Cabe

\footnotetext{
482 Ibidem. Pag. 285.

${ }^{483}$ AGAMBEN, Giorgio. Tempo e História: crítica do instante e do contínuo In Infância e História: Destruição da experiência e origem da história. Trad. Henrique Burigo. Belo Horizonte. Ed. UFMG/Humanitas. 2012. p. 111.

${ }^{484}$ Ibidem.
} 
dizer que Agamben está, aqui, preocupado com uma concepção temporal que possa exprimir a historicidade, preocupação original completamente diversa da de Bergson que visava a, em sua crítica à concepção aristotélica, uma dimensão do tempo que exprimisse o tempo presente na evolução que marca a vida e o cosmos.

A nosso ver, ao se preocupar com ambas as dimensões da temporalidade, a concepção de instante poético de Octavio Paz nos apresenta uma solução que contempla tanto a dimensão ontológica quanto a dimensão histórica, por não as tomar em sentidos contraditórios. Em alguns momentos, o instante parece assombrar o poeta tal qual uma revelação. Ao vivenciá-lo, o poeta se perde na distensão da totalidade do tempo, que rompe com os pontos fugazes e desfaz a aparência de movimento, dandoIhe a consciência da eternidade do evento, compreendido de uma única vez:

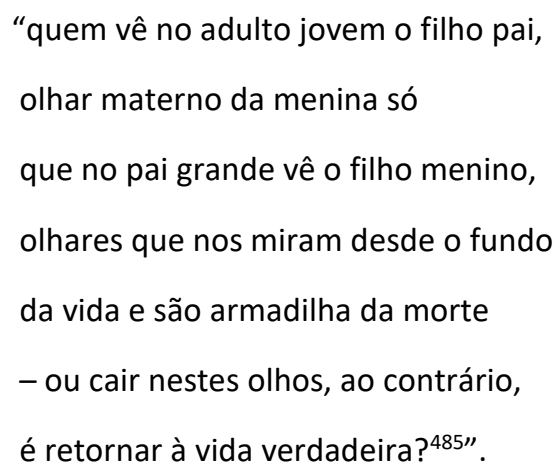

A totalidade do ser abarca a compreensão de que, para Paz, entre a vida e a morte a diferença é apenas um distanciamento de grau, visto que um oposto é complementar do outro. Da mesma forma, o impulso vital presente nas diferentes fases da vida é o mesmo: o filho, tal como o pai, ainda que diferente, é sempre o mesmo. Tal como a figura da mônada que, no olhar prismático da história, conserva na partícula de um evento a universalidade do acontecimento total, o instante poético conserva, na mirada que dele se faz (através de um ato intuitivo) a totalidade do ser: historiografia e ontologia se dão as mãos através do tempo. A verdadeira vida é esta que é observada neste instante que não se mensura e que não se reduz a um ponto fixo no espaço:

485 PAZ, Octavio. Pedra de Sol. Trad. Horácio Costa. São Paulo: Annablume, 2009. p. 33. 


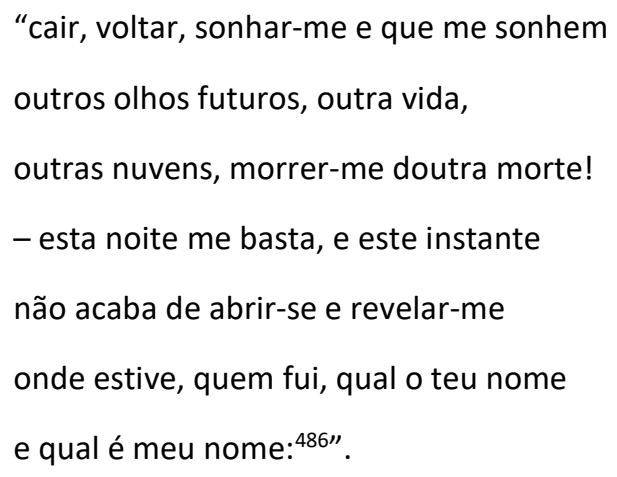

O instante nos basta, pois uma vez nele, nada está posto fora. As próprias imagens do poema operam como estas mônadas que conservam a luz da totalidade lúcida. Total, posto que em seu interior, a ruptura com o exterior se consagra graças à morte da oposição entre as figuras, isto é, graças à metaforização que vincula, simpática e analogamente, as imagens que o constituem. Segundo Horácio Costa,

\footnotetext{
"de fato, "pedra" e "sol" são as mônadas, abstrações todo-poderosas em torno às quais esculpe o poeta suas possibilidades verbais: opacidade e luminosidade, negrume e transparência, Queda e Ascensão, matéria bruta e inteligência formadora, aceitação e desejo, formam um tecido variado de correspondências e intercâmbios em que, por fim, ressalta-se como constante a poética da luz em $\mathrm{Paz}^{487 \prime \prime}$.
}

Estas correspondências, possuidoras de uma conexão estabelecida por uma íntima relação de simpatia rítmica, perfilam, lado a lado, graças ao poder anti-contraditório e anti-dialético da imagem, onde tudo o que se transfigura em outra coisa recebe o significado de "sagrado". Há que se aprofundar, contudo, como esta ponte entre as imagens pode vir a se estabelecer do ponto de vista ontológico.

Neste sentido, a dificuldade do retorno à intuição em que se dá a experiência temporal do instante poético e sobre como ela pode abarcar algo tão móvel como o

\footnotetext{
486 Ibidem.

${ }^{487}$ COSTA, Horácio. Nota do tradutor In PAZ, Octavio. Pedra de Sol. São Paulo: Annablume, 2009. p. 78.
} 
tempo é que possuímos duas formas de expressão, em que geralmente uma devora a outra. Em A Intuição Filosófica, Bergson destaca que

\footnotetext{
"não temos senão dois meios de expressão, o conceito e a imagem. É através de conceitos que o sistema se desenvolve; é numa imagem que ele se comprime quando o empurram para a intuição de onde deriva: porque se se quiser ultrapassar a imagem elevando-se acima dela, volta-se necessariamente a cair nos conceitos, e em conceitos mais vagos, mais gerais ainda do que aqueles de onde se tinha partido à procura da imagem e da intuição ${ }^{488}$.
}

Como afirmamos acima, o conceito tem a função de realizar cortes na realidade, submetendo-a às representações úteis à nossa vida. Se se quer, portanto, fazer uso da imagem para compreensão através do método intuitivo, deve-se levar em conta que a percepção ordinária da vida prática está sob ordem destes pressupostos, ou seja, da inteligência. Contudo, o método intuitivo bergsoniano possui forte correlação com a própria duração e o ímpeto (impulso) que move a todas as criaturas e que se recria no tempo, incessantemente. Em vista disso, a intuição não pode ser um ponto de partida de uma unidade, mas ela deve seguir o comboio da duração em andamento, pois esta matéria da percepção é móvel. E a razão para isto é que não podemos admitir que existam "instantes" petrificados, imóveis e, consequentemente, vazios, que a racionalidade científica e técnica, bem como a inteligência, admite como existentes no interior desta continuidade ininterrupta chamada tempo.

Para Bergson, não há imobilidade, não há estado estático das coisas, apenas o fluir contínuo. O que evoca uma questão, por si mesma, impossível, pois não há propriamente um "estado" das coisas, muito menos da alma, pelo menos não no sentido em que estamos habituados, como coisa estática, estável, imóvel. Acrescente-se: “A verdade é que mudamos constantemente, e que o próprio estado é já mudança ${ }^{489 " . ~ E s s e ~}$ "estado constante de transformação" admite, na percepção de Bergson, uma transição

\footnotetext{
${ }^{488}$ BERGSON, Henri. A Intuição filosófica. Trad. Maria do Céu Patrão Neves. Edições Colibri. Lisboa. 1994. p. 49.

489 BERGSON, Henri. A Evolução Criadora. Trad. Pedro Elói Duarte. Lisboa: Edições 70, 2001. p. 13.
} 
que, muitas vezes, não chega sequer a ser qualitativa, mas apenas gradativa: por exemplo, a transição evolutiva dos compostos inorgânicos aos orgânicos, matéria de dúvida para biologia, sobretudo no que toca à questão sobre a origem da vida, pode ser interpretada como um caso de transformação qualitativa no tempo. Nossa experiência psicológica opera cisões localizadas nos fenômenos, estabelece limites entre eles, porque lhe interessa a descontinuidade, pois ela é o que nos permite operar sobre o mundo. Como pensar, então, em algo para além dos recortes objetivos que a inteligência efetua no real, através da intuição? Devemos obstruir a inteligência?

Em primeiro lugar, é preciso ter em mente que a duração é imanente ao real, como diz o autor:

\footnotetext{
“o universo dura. Quanto mais aprofundarmos a natureza do tempo, melhor compreenderemos que duração significa invenção, criação de formas, elaboração contínua do absolutamente novo. Os sistemas da ciência só duram porque estão indissociavelmente ligados ao resto do universo ${ }^{490 \prime \prime}$.
}

Ou seja, o todo se move segundo os princípios da duração. Em segundo lugar, é preciso ter claro que pensar a duração é pensar em duração, pois o Ser é tempo. Assim como o amor, nosso pensamento acerca de uma experiência tão sensível e tão intuitiva quanto o tempo pressupõe uma dose de experiência para que possamos, enfim, qualificá-lo de forma correta. Quando Bergson afirma que o tempo é o estofo da realidade, ele está pensando em termos ontológicos, está concebendo o tempo como algo vinculado à criação das coisas. Inverte-se a postura analítica de Aristóteles: o movimento, aqui, não é apenas um atributo qualitativo das coisas; pois, as coisas surgem porque há movimento. O maior exemplo dessa transitoriedade processual, progressiva, pode ser encontrada na evolução das espécies (já apontada anteriormente). É ela, enquanto ruptura do paradigma da imobilidade na ciência, que nos oferecerá a noção de élan vital. A apreensão deste élan originário, portanto, não se dará através de um método que cria descontinuidades na realidade.

490 Ibidem. p. 21. 
O élan vital é o próprio movimento que atravessa o universo e cria as formas, tais como um caminhar incessante na areia que deixa lá as suas pegadas. O caminhar não cessa e as pegadas, a depender da distância, são meros vestígios memoriais (tais quais as formas de uma matéria movente). Neste sentido, a poesia é um dos discursos, por assim dizer, que melhor figura esta ideia movente. Octavio Paz faz do caminhar, como em El Mono Gramatico a atividade da gestação do tempo. Em outras palavras, o caminho como texto é também uma metáfora do mundo natural, como no trecho:

\footnotetext{
“Una página de enmarañada caligrafía vegetal. Maleza de signos: ¿cómo leerla, cómo abrirse paso entre esta espesura? Hanumãn sonríe con placer ante la analogía que se le acaba de ocurrir: caligrafía y vegetación, arboleda y escritura, lectura y camino. Caminar: leer un trozo de terreno, descifrar un pedazo de mundo. La lectura como un camino hacia... El camino como una lectura: ¿una interpretación del mundo natural? ${ }^{491 " .}$
}

Cabe acrescentar que o andar como metáfora da transformação implacável do tempo também está presente na tradição poética de língua portuguesa. Se pensarmos num Camilo Pessanha, por exemplo, destacaríamos os versos deste soneto de Clepsidra:

"Quando voltei encontrei os meus passos

Ainda frescos sobre a úmida areia.

A fugitiva hora, reevoquei-a,

- Tão rediviva! nos meus olhos baços...

Olhos turvos de lágrimas contidas.

- Mesquinhos passos, porque doidejastes

Assim transviados, e depois tornastes

Ao ponto das primeiras despedidas?

Onde fostes sem tino, ao vento vário,

${ }^{491}$ PAZ, Octavio. El mono gramatico. 3a ed. Barcelona: Seix Barral, 1990. p. 13. 
Em redor, como as aves num aviário,

Até que a asita fofa Ihes faleça...

Toda essa extensa pista - para quê?

Se há de vir apagar-vos a maré,

Com as do novo rasto que começa... ${ }^{492 " .}$

O novo rasto que começa indica que o movimento do tempo, independente da forma como o apreendemos, é incessante. Esta ideia pode ser compreendida como o movimento originário que impulsiona e, múltipla e ordenadamente, expressa o desenvolvimento progressivo no tempo da vida. As pegadas na areia serão, aqui, marcas da tendência evolutiva que Bergson associa à maneira com a qual os seres vivos irão extrair energia do universo material à sua volta, deixado pelo movimento levado a cabo graças ao élan vital. Mais importante que as formas na areia é a formação que as consolida: a caminhada. As pegadas, por si mesmas, assim como as marcas estáticas da evolução, são facilmente apagadas pelo fluir incessante das ondas e do tempo.

Diante desse movimento, surge uma preocupação em Bergson, a de expressar esse movimento da Duração: a questão da possibilidade de pensarmos em duração. Preocupação que intenciona que as palavras possam dar conta da representação do fluxo contínuo, mesmo sabendo da limitação da nossa linguagem e do seu caráter representativo, em vista da sua natureza utilitária, uma vez que é expressão da nossa inteligência, como indicamos anteriormente. Para que possamos falar da dificuldade em conhecermos o mundo, em pensarmos no tempo "em duração", devemos considerar o problema da diferença rítmica entre os seres e como esta dificuldade se coloca como uma barreira à nossa compreensão. Esse problema fica evidente no trecho que se segue ao anterior: "A causa profunda desta dissonância reside numa irremediável diferença de ritmo ${ }^{493 " . ~ A ~ d i f e r e n c ̧ a ~ d e ~ r i t m o ~ m a r c a ~ a ~ e s s e n c i a l ~ d i s t i n c ̧ a ̃ o ~ e n t r e ~ o s ~ s e r e s ~-~ c u j a ~}$ natureza possui, em cada caso, uma maneira única de manifestar sua própria duração -

\footnotetext{
492 PESSANHA, Camilo. Clepsidra e poemas dispersos. Introdução biográfica e crítica, organização e notas de António Quadros. Lisboa: Publicações Europa-América, 1920. Disponível em: https://literaturabrasileira.ufsc.br/documentos/?action=download\&id=38030\#INSCRI\%C3\%87\%C3\%830 [acesso em 28 de junho de 2019].

${ }^{493}$ BERGSON, Henri. A Evolução Criadora. Trad. Pedro Elói Duarte. Lisboa: Edições 70, 2001. p. 21.
} 
e é a razão de não conseguirmos compreender, através de nossa inteligência e sua tendência imobilizadora, como existe uma totalidade movente que as torna indistinguíveis quando dadas no processo contínuo. A compreensão dessa totalidade é possibilitada pela intuição, que expande nossas fronteiras perceptivas.

Como já dissemos acima, a intuição é um procedimento metódico utilizado por Bergson para que possamos chegar à verdade filosófica. É na fluidez da intuição que o autor busca uma expressão imagética da realidade. Esta expressão imagética se assimila à expressividade artística, pois há, não obstante, o uso de metáforas, e esta se vale da descrição dos efeitos subjetivos que o mundo nos causa, a fim de apreendermos a duração. Entretanto, Franklin Leopoldo e Silva apresenta uma condição necessária a esta aproximação. Trata-se da diferença entre o enfoque filosófico e o artístico no que toca ao uso da imagem. A despeito de suas afinidades, não os podemos tomar como idênticos entre si. Silva afirma que

\footnotetext{
"a filosofia de Bergson, por recusar o conceito na sua acepção tradicional como linguagem adequada para a filosofia, procurará na expressão imagética a alternativa para uma expressão metafórica mais aderente ao real. [...] É a imagem no contexto de sua utilização literária aquela que pode substituir com vantagem o conceito: portanto é a questão do paradigma literário que está em jogo quando se tenta encontrar para a filosofia uma linguagem mais precisa do que o conceito ${ }^{494 \prime \prime}$.
}

A diferenciação de paradigmas faz-se necessária, apesar de a filosofia assim como a literatura se preocupar em pensar a vida das coisas e não apenas seus procedimentos lógicos internos.

Interessante notar, neste tópico, o contraponto desta visão com a de MerleauPonty que, retomando a expressão da linguagem como a mansão do Ser (como dada em Heidegger), diz que esta opera no mundo para dar voz às coisas, como fica explícito no trecho de Le visible et l'invisible: "É preciso portanto crer que a linguagem não é

\footnotetext{
${ }^{494}$ SILVA, Franklin Leopoldo. Bergson: intuição e discurso filosófico. São Paulo: Loyola, 1994. p. 186
} 
simplesmente o contrário da verdade, da coincidência que há ou que poderia haver", ou seja, segundo Merleau-Ponty, o filósofo busca "uma linguagem da coincidência, uma maneira de fazer falar as próprias coisas ${ }^{495 " . ~ A i n d a ~ s o b r e ~ e s t e ~ c a r a ́ t e r ~ d a ~ l i n g u a g e m, ~}$ Octavio Paz diz em O Arco e a Lira que

\begin{abstract}
"as palavras se comportam como seres caprichosos e autônomos. Sempre dizem "isto e aquilo" e, ao mesmo tempo, "aquilo e o que vem depois". o pensamento não se resigna; obrigado a usá-las, repetidas vezes pretende reduzi-las a suas próprias leis; e repetidas vezes a linguagem se rebela e explode os diques da sintaxe e do dicionário. [...] Daí que, como se a língua fosse algo estático, a gramática afirme que se trata de um conjunto de palavras e que estas constituem a unidade mais simples, a célula linguística. [...] [Mas], o idioma é uma totalidade indivisível ${ }^{496 ”}$.
\end{abstract}

Buscar esta linguagem da coincidência esbarra na percepção de que o aparato linguístico que utilizamos é limitado. Mas, ainda que suas fronteiras se fechem, a linguagem é o que temos para pensar o real, por isso é preciso considerar as diversas modalidades de pensamento e de uso da linguagem, sobretudo aquelas capazes de extravasar, ainda que não totalmente, os muros anteriormente impostos pelas próprias palavras.

A experiência que é marcada pelo mergulho no fluxo temporal, ou seja, ato em que a intuição se aprofunda na duração, tem um momento de liberdade. Esta liberdade assume um caráter criativo. $O$ gesto criador consiste em um fazer não-analítico, nãoabstrato e não-decomposto, pois é contínuo, indivisível e concreto. Se há uma divisão, tal como a operada pelo nosso entendimento, é exclusivamente posterior. O gesto criador não é, portanto, uma recomposição de partes esparsas, que demandariam um modelo seguro preestabelecido. Estamos inseridos no absoluto movente e, ao tocá-lo, tal como a inteligência o toca, não estamos a conhecê-lo em sua totalidade (devido ao

\footnotetext{
495 PONTY, Merleau. Le visible et l'invisible. apud PRADO JR. Presença e campo transcendental: consciência e negatividade em Bergson. São Paulo: Edusp, 1989, p. 62

${ }^{496}$ PAZ, Octavio. Op. Cit., 2012. p. 56.
} 
recorte já apontado), mas sim, estamos possibilitados de vir a absorvê-lo em nossa percepção alargada, tal como na experiência do sagrado.

Ora, para Paz, se tudo o que se transfigura é sagrado, temos nesta transmutação do ser um contato com o que poderíamos chamar, talvez num sentido metafísico, de Absoluto. Na parte central de Pedra de Sol, onde somos lançados a uma data específica da história, em que o poeta canta um de seus versos mais eróticos, a experiência da duração parece incorporar um sentido resistente à marcha inefável não apenas do tempo, mas da ameaça da própria história e seu produto mais temeroso: a guerra. Ao situar o evento amoroso, oferecendo-Ihe não apenas um lugar, mas uma data, Octavio Paz reestabelece o sentido cíclico ao tempo cronológico e, com isto, faz irromper - tal qual um feriado que nos retira do ritmo de produção - um novo regime temporal, em que se afirma a temporalidade erótica do amor. Trata-se, especificamente, do ano de 1937, poucos anos antes do fim da guerra civil espanhola, em que a vitória de Franco, apoiado pelas forças do Eixo, devastou a Plaza del Ángel através de seu imperioso arsenal técnico-militar. No meio desta zona de destruição, Paz parece perfurar todo o ritmo em marcha da modernidade técnica com os versos:

\footnotetext{
"os dois se desnudaram e se amaram

para defender nossa porção eterna,

nossa ração de tempo e paraíso,

tocar e recuperar nossa raíz,

recuperar a herança arrebatada

há mil séculos por ladrões de vida,

os dois se desnudaram e se amaram

porque os desnudos corpos enlaçados

o tempo anulam, são invulneráveis,

nada os toca, retornam ao princípio,

não há tu ou eu, ontem, amanhã,

ou nomes, verdade num só corpo e alma,

oh ser total... ${ }^{497}$ “
}

497 PAZ, Octavio. Pedra de Sol. Trad. Horácio Costa. São Paulo: Annablume, 2009. p. 39. 
Poderíamos compreender este "ser total" na acepção com que Aristófanes apresenta o seu mito do andrógino no diálogo platônico O Banquete, onde as partes de uma mesma alma, ao se reencontrarem após longo período perdidas uma da outra - graças a um castigo divino - voltam a se fundir e a formar a figura esférica que antes era perfeita, coisa sagrada, pois criação à imagem das figuras celestes e divinas. Tornado data marcada no calendário, feriado, Paz converte este instante em origem arquetípica. Para Paul Henri Giraud, trata-se de um "amor arrancado à guerra, à morte, amor desesperado, talvez - mas amor fora do tempo, insensível à história, amor arquetípico, absoluto, integral ${ }^{498 "}$. Neste instante, os amantes como que saltam para a outra margem, tornam-se invulneráveis à ameaça que explode prédios do lado de fora da janela, por estarem vivenciando um regime de duração que é apenas o que lhes pertence. Este tipo de experiência aproxima-se da experiência religiosa, do contato com a graça, cujo sentido místico é latente, se interpretarmos que o último verso, interrompido na metade, aponta, de fato, para a totalidade do Ser enquanto o próprio Absoluto. Talvez este contato com o "ser total", tal como Paz o chama, seja o que todos nós, em alguma medida, acedemos quando descobrimos a possibilidade da experiência da outridade e passamos por ela. Em La llama doble, Paz é enfático neste sentido: "el erotismo es ante todo y sobre todo sed de otredad. Y lo sobrenatural es la radical y suprema otredad ${ }^{499 "}$. Ainda para Giraud, esta experiência nos vem carregada de caracteres bergsonianos, uma vez que se trata da "intuição pura da duração, através destas duas mediações sagradas que são, tanto para Paz como para Breton, o erotismo e a poesia ${ }^{500 " . ~ C o n v e ́ m ~ d i z e r ~ q u e ~ O c t a v i o ~ P a z ~ a p r o x i m a ~ a ~ p o e s i a ~ d a ~ e x p e r i e ̂ n c i a ~ m i ́ s t i c a, ~}$ da experiência religiosa e do amor, cuja origem, para o mexicano, é comum. Em o Arco e a Lira, encontramos:

\footnotetext{
“o sagrado nos escapa. Ao tentar captá-lo, descobrimos que tem origem em algo anterior e que se confunde com nosso ser. Outro tanto acontece com o
}

\footnotetext{
498 GIRAUD, Paul Henri. Octavio Paz: caminho para a transparência. Trad. António Teixeira. Lisboa: Instituto Piaget, 2002. p. 252.

499 PAZ, Octavio. La Llama Doble. Barcelona: Seix Barral, 2001. p. 22.

${ }^{500}$ GIRAUD, Paul Henri. Ibidem. p. 253.
} 
amor e a poesia. As três experiências são manifestações de algo que é a própria raiz do homem. Nas três pulsa a saudade de um estado anterior. E esse estado de unidade primitiva, do qual estamos sendo separados a cada momento, constitui a nossa condição original, à qual voltamos uma e outra vez ${ }^{501 "}$.

Esta volta é o que alcançamos quando realizamos o salto mortal no amplexo amoroso. Não por menos, Paul Henri Giraud cita os versos de Breton onde esta ideia aparece com força: "O amplexo poético como o amplexo da carne/ enquanto dura/ Impede qualquer escapadela para a miséria do mundo ${ }^{502 " .}$

Similarmente, Bergson apresenta, em Essai sur les donnés immédiates de la conscience, uma definição filosófica de graça:

\footnotetext{
«Les sentiments esthétiques nous offrent des exemples plus frappants encore de cette intervention progressive d'elements nouveaux, visibles dans l'emotion fondamentale, et qui semblent en accroîte la grandeur quoiqu'ils se bornent à en modifier la nature. Considérons le plus simple d'entre eux, le sentiment de la grâce. Ce n'est d'abord que la perception d'une certaine aisance, d'une certaine facilité dans les mouvements extérieures ${ }^{503}$ ».
}

Achamos relevante chamar a atenção para uma aproximação entre a experiência da graça à experiência estética, cujo sentido pode ser entendido como experiência da sensibilidade (em conjunção com aquilo que a estimula, como a arte), visto na experiência poética, a partir da qual estabelecemos com o mundo uma relação rítmicotemporal completamente outra, cuja duração cronométrica nos escapa. A graça é compreendida como um alargamento sensorial, perceptivo, que nos permite maior facilidade na compreensão do que está dado imediatamente à nossa consciência pelo

\footnotetext{
501 PAZ, Octavio. O Arco e a Lira. Trad. Ari Roitman e Paulina Wacht. São Paulo: Cosac Naify, 2012 p. 143. 502 BRETON, André. No caminho de San Romano, Poema s (1948), Oeuvres completes, tomo III, p. 412. Poema traduzido por Paz em Versiones y diversiones. In GIRAUD, Paul Henri. Ibidem. 2002. p. 253. 503 BERGSON, Henri. Essai sur les données immédiates de la conscience. Gèneve: Édition Albert Skira, 1945. p. 22.
} 
fluxo do real. A diferença entre ambas as experiências reside em seu sentido. Paz afirma em Poesia de solidão e Poesia de comunhão que:

"um crítico francês pôde dizer que enquanto o poeta tende à palavra, o místico tende ao silêncio". Essa diferença de direções distingue, por fim, a experiência mística da expressão poética. A mística é uma imersão no absoluto; a poesia é uma expressão do absoluto ou da extraviada tentativa de se chegar a ele ${ }^{504 \prime}$ (negrito nosso).

Para Octavio Paz, a nossa condição original é a temporalidade, pura e sem lastro. Novamente em $O$ Arco e a Lira, o poeta afirma que no encontro amoroso, existe a conjugação entre sede e satisfação. Somos, de forma simultânea, o alimento e a boca que o deglute. O mesmo se passa com nossa experiência da temporalidade:

“O homem, dizem os modernos, é temporalidade. Mas essa temporalidade quer aquietar, saciar, contemplar a si mesma. Flui para satisfazer-se. O homem se imagina; e ao imaginar-se ele se revela. O que é que a poesia nos revela? ${ }^{505 "}$

O que a aproxima a experiência da graça da experiência poética é que ambas comungam da conjunção de ritmos, onde, em uma temos a imersão no absoluto e, na outra, o jogo do poeta com a palavra na sua tentativa de expressão. Assim, graça e poesia, na comunhão suprema, o amor volve os amantes

\footnotetext{
"fechados como conchas

o tempo vem inútil assediá-los,

não há mais paredes nem tempo: espaço, espaço, abre a mão, come esta riqueza, corta os frutos, corta e come da vida,
}

504 PAZ, Octavio. Poesia de Solidão e Poesia de Comunhão In A Busca do Presente. Trad. Eduardo Jardim. Rio de Janeiro: Bazar do Tempo, 2017. p. 21.

505 PAZ, Octavio. O Arco e a Lira. Trad. Ari Roitman e Paulina Wacht. São Paulo: Cosac Naify, 2012. p. 143. 
estende-te ao pé da árvore, bebe a água! ${ }^{506 \prime \prime}$.

Como na comunhão, a experiência do amor é mística e sagrada, pois religa (no sentido etimológico do termo) o ser humano ao ritmo de duração da própria vida. Podemos explicar esta conjunção como uma correspondência entre o ritmo do sujeito e o ritmo do mundo, como se ambos estivessem associados ou, nos termos bergsonianos, como se a nossa percepção não as distinguisse e conseguisse reconhecer nelas uma totalidade.

Na experiência poética, quem realiza este tipo de operação é o próprio ritmo. Se, por um lado, a palavra poética é imagem e sentido, por outro, esta manifestação aparece simplesmente como ritmo. Octavio Paz, na mesma obra, afirma que nossa condição original, a temporalidade, se manifesta no "manancial ritmo-imagem". Este manancial é a conjunção entre duas esferas do ser que nossa inteligência tende a dissociar, mas cuja conexão é resgatada pelo poetar que, nas palavras de Paz, pode ser definido da seguinte maneira:

\footnotetext{
“ato poético, o poetizar, o dizer do poeta - independentemente do conteúdo particular desse dizer - é um ato que não constitui, pelo menos originalmente, uma interpretação, e sim uma revelação de nossa condição. Quer fale disto ou fale daquilo, [...] a palavra poética é ritmo, temporalidade emanando e se engendrando incessantemente. $E$, sendo ritmo, é imagem que abraça os opostos, vida e morte num único dizer ${ }^{507 "}$.
}

Há, portanto, uma correlação bastante estreita entre ritmo e imagem que, juntos, presidem, transformam e transmutam o universo. O ritmo se converte, neste sentido, em imagem de mundo e retira desta afinidade rítmica a sua relação de regência para com as mais diversas sociedades e suas formas de fazer arte, política, religião, amor, etc.

No entanto, por qual razão, nestes momentos em que a experiência poética se realiza com liberdade, podemos considerar que dentro desta conjunção de ritmos

\footnotetext{
506 PAZ, Octavio. Pedra de Sol. Trad. Horácio Costa. São Paulo: Annablume, 2009. p. 41.

507 Id. O Arco e a Lira. Trad. Ari Roitman e Paulina Wacht. São Paulo: Cosac Naify, 2012. p. 155.
} 
distintos, há uma aproximação ao real? Ainda nos Essai sur les donnés immédiates de la conscience, Bergson afirma:

\begin{abstract}
"comme des mouvements faciles sont ceux qui se préparent les uns et les autres, nous finissons par trouver une aisance supérieure aux mouvements qui se faisant prévoir, aux attitudes présents où sont indiquèes et comme préformées les attitudes à venir. [...] Si la grâce préfère les courbes aux lignes brisées, c'est que la ligne courbe change de direction à tout moment, mais que chaque direction nouvelle était indiquée dans celle qui la précédait. ${ }^{508}$ ».
\end{abstract}

Trata-se, então, de prever, no movimento dado, a simpatia. A simpatia que se estabelece entre seres alhures pode ser considerada como uma relação analógica interposta entre nós e a realidade material. O nó que entrelaça estes fios distintos é o próprio ritmo destes seres em correspondência: «C'est le rythme et la mesure, en nous permettant de prévoir encore les mouvements de l'artiste, nous font croire cette fois que nous en sommes maîtres ${ }^{509}$ ». A concepção faz-nos crer que somos mestres destes movimentos, não apenas por nossa percepção deste fato estar analogicamente atrelada a outro através do ritmo, mas porque este ritmo expressa o que está se formando, o que está em criação temporal. Para Horkheimer, em sua compreensão sobre a metafísica bergsoniana,

\footnotetext{
"este tempo concreto, "realizado", que o filósofo compreende como nossa própria essência, ele o vê, num ato de simpatia, também como o interior da totalidade do mundo. A realidade verdadeira seria um fluir contínuo e incessante que, tanto em cada indivíduo como na totalidade do mundo, engloba constantemente a totalidade do passado com toda novidade do instante, e com ele prossegue ${ }^{510 ”}$ (itálico nosso).
}

\footnotetext{
${ }^{508}$ BERGSON, Henri. Essai sur les données immédiates de la conscience.Gèneve: Édition Albert Skira, 1945. p. 22. 509 Ibidem. p. 23. 510 HORKHEIMER, Max. Sobre a metafísica do tempo de Bergson. Cadernos de Filosofia Alemã - USP. 2000. p. 68.
} 
Por isso, Bergson compara este processo à audição de uma música. Mentalmente, quando a escutamos e percebemos seu ritmo e ordenação intrínsecos, podemos prevêlo, num passo sequencial, e podemos, através da sensibilidade, "deduzir" sensivelmente certos movimentos. Desta forma, a experiência da graça se aproxima de uma experiência estética, de um signo abrangente da mobilidade do real.

Para David Lapoujade, os atos de simpatia são fundamentais para compreendermos o método intuitivo. O comentador aponta que para Bergson, em Le Pensée et le mouvant, a simpatia pode ser compreendida como "a intuição [...] através da qual nos transportamos ao interior de um objeto para coincidir com aquilo que ele tem de único e, consequentemente, de inexprimível ${ }^{511 " .}$ A simpatia estabelece, portanto, um ato de contato com o interior do objeto intuído. Mas esta conexão só é possível porque algo a garante. A nosso ver, a forma como a percepção poética estabelece essa conexão a partir de uma analogia rítmica entre as coisas é similar: tratase de vislumbrar as coisas despidas de seu invólucro conceitual e sua redutiva definição escassa. É necessário pontuar que, para Bergson, uma das razões pelas quais esta conexão se sustenta é a memória do objeto e da forma como construímos, em relação a ele, nossas afinidades e afetos. Neste sentido, apesar da diferença, há uma aproximação do ato poético porque este também é, por sua vez, um ato afetivo. A intuição filosófica é "a intuição que atinge o espírito, a duração, a mudança pura512". Trata-se, pois, de um ato do espírito que se volta para si mesmo. Como poderia ela tornar-se sensível, isto é, voltar-se para "outros níveis de realidade": o vital, o material, o social, o pessoal, etc? Ao que nos responde Lapoujade: "ela procede por simpatia. De maneira ainda abstrata, podemos definir a simpatia como o movimento por meio do qual cada uma dessas realidades se torna "espírito ${ }^{513 \prime \prime \prime " . ~ A c r e s c e n t e-s e ~ q u e ~ a ~ r e l a c ̧ a ̃ o ~}$ entre analogia e simpatia está dada no próprio bergsonismo. Lapoujade aponta que "a simpatia é diferente de uma fusão sem distância que a assimilaria grosseiramente a um ato intuitivo. Ela repousa, pelo contrário, em um raciocínio por analogia ${ }^{514 " ~(n e g r i t o ~}$

\footnotetext{
${ }^{511}$ LAPOUJADE, David. Potências do tempo. Trad. Hortencia S. Lencastre. São Paulo. N-1. ed. 2013. p. 51 512 Ibidem.

513 Ibidem.

514 Ibidem. p. 56.
} 
nosso). Quando clarificadas as razões da analogia, que estabelece a conexão entre as diferentes tendências dos seres, há também uma clarificação quanto à origem, o impulso inicial daquele ser e cujo élan permite que ele se desenrole no tempo, isto é, no mundo. Clarificados porque interiorizados em nós: neste sentido, apaga-se a diferenciação entre a tendência interna de um ser e nosso sujeito, mais, apaga-se a diferença entre ambos, visto que o princípio-chave da analogia é o coincidentia oppositorum.

Ao apreendê-lo, ocorre uma transformação espiritual no sujeito, de modo que o todo se naturaliza no interior de um eu que intui. Tocamos o absoluto, expressiva ou imersivamente, como nos mostra Octavio Paz. Eis o potencial, para David Lapoujade, do raciocínio por analogia, pois para ele

\footnotetext{
“a intuição filosófica é esse contato, a filosofia é esse impulso'. Reconhecemos aqui o movimento da intuição, mas também o fundamento da analogia. A analogia estabelece-se sempre dinamicamente entre nossas próprias tendências, percebidas intuitivamente, e as do universo (social, vital, material, etc.) projetivamente concluídas. Somos análogos ao universo (intuição); inversamente, o universo é análogo a nós (simpatia). A analogia recobre esse domínio, muito vasto em Bergson, do como se $e^{515 "}$.
}

Este "toque no absoluto" também poderia ser compreendido como uma experiência nostálgica. Num dos diálogos estabelecidos entre Anthony Stanton e Octavio Paz acerca da natureza do poema, temos o seguinte:

\footnotetext{
“Octavio Paz: [...] um sentimento comum a todos os seres humanos: não estamos sós; o desejo de romper o nosso solipsismo; um sentimento de fraternidade com os outros e com o mundo; e talvez uma certa nostalgia do além...

Anthony Stanton: Uma nostalgia do absoluto!

Octavio Paz: Uma intuição momentânea da presença... de quem ou de quê? Em mim a consciência do apagamento das antigas presenças e certezas estava (ainda está) muito viva. Creio que é qualquer coisa que partilhamos todos, nós,
}

515 Ibidem. p. 59. 
os homens modernos. Nostalgia, sem dúvida; mas também a decisão de viver com constância a nossa situação ${ }^{516 "}$.

No interior da poesia, a linguagem opera como a própria experiência da graça, isto é, do sagrado, uma vez que permite, dentro das suas fronteiras, um transcender ao Absoluto que, apesar de não ser um abandono da experiência linguística, certamente é sua superação, como Paz parece nos sugerir nos versos

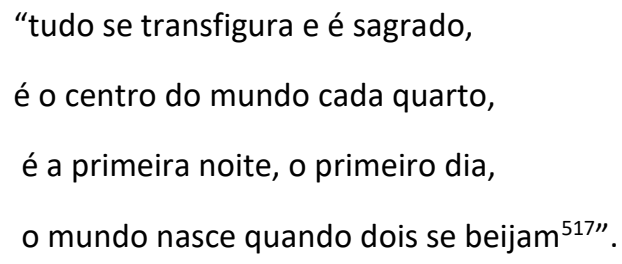

Alargamento da percepção, a graça e a sensibilidade poética são duas formas de perceber e captar no mundo as relações de analogia e simpatia entre os seres, ou seja, os momentos oportunos em que os diferentes ritmos de temporalidade conjugam-se numa única via. Graças a esta possibilidade de percepção, a linguagem pode passar a operar como criadora do real, estabelecendo as afinidades íntimas, através de poderosas ferramentas, como é o caso do uso da metáfora. Ou seja, ainda que a poesia possa ser decomposta em elementos fixos, assim como a música, os quais requerem nossa atenção, tal qual em uma análise, ela só é poesia e só consegue se expressar enquanto um tipo de arte, enquanto um tipo de expressão da sensibilidade que se dá no tempo. A esse respeito, estes elementos que a compõem poderiam ser, por exemplos, determinadas palavras de um verso, determinada estrofe isolada, mas não, como se poderia pensar, instantes pontuais. Octavio Paz afirma em O Arco e a Lira que, assim como na Linguística de Jakobson, a linguagem deve ser compreendida como uma totalidade indivisível, definindo-se apenas por relação às outras partes dadas num contexto, num código comum; o poema, expressão mais pura da linguagem, encontra a sua unidade indivisível no ritmo. O mundo nasce quando dois se beijam, pois o amplexo

\footnotetext{
${ }^{516}$ STANTON, Anthony. Liberdad bajo palabra: a genealogia de um livro e de um poeta, p. 155- p. 156. In GIRAUD, Paul Henri. Ibidem. p. 264.

517 PAZ, Octavio. Pedra de Sol. Trad. Horácio Costa. São Paulo: Annablume, 2009. p. 41.
} 
erótico, como se verá em nossa análise de Blanco nos remete ao par original em seus dias no Éden, no instante que transfigura o tempo em Paraíso.

Pode-se dizer, portanto, que a poesia, assim como a experiência da graça, funda uma espécie de temporalidade própria? Bento Prado dá destaque à seguinte citação: “A percepção de uma facilidade nos movimentos vem aqui fundir-se no prazer de interromper de alguma maneira a marcha do tempo e de conter o futuro no presente ${ }^{518 "}$. Ora, o que significa interromper a marcha do tempo? Convém explicar que o futuro sempre aporta, na nossa percepção da vida prática, com o desejado, ou seja, como aquilo que é já preparado por nossa memória, como a expectativa do seu desdobramento prático. Ao realizar uma interrupção da marcha, a arte nos abre ao novo, ainda que este novo possa ser previsto pela nossa aproximação ao ritmo de sua realização. Assim, "o tempo deixa de ser abismo e separação; dá-se em seu interior uma suspensão da "diáspora" das dimensões temporais, que se fundem criando a circularidade de um supratempo ou de uma "eternidade viva ${ }^{519}$ ". Supratempo ou "eternidade viva" que se assimila, pois, ao instante poético e ao instante místico que estamos tratando aqui, graças à sua vivacidade de natureza imensurável.

A afirmação do amor em Pedra de Sol reforça-se nos versos abaixo, complementada pela constatação de que esta experiência nos devolve "o esquecido assombro de vivermos ${ }^{520 "}$. Neste trecho do poema, temos a libertação das pulsões, como se este ato de libertar fosse um retorno da essência das coisas às coisas mesmas. Neste sentido, o que Paz compreende por presença fica mais claro, uma vez que se trata da operação poética pela qual o poeta devolve às coisas que nomeia a sua qualidade essencial e intransferível:

\footnotetext{
"amar é combater, se dois se beijam

o mundo é outro, encarnam-se os desejos,

o pensamento encarna, brotam asas
}

\footnotetext{
518 PRADO JR, Bento. Presença e campo transcendental: consciência e negatividade em Bergson. São Paulo: Edusp, 1989. p. 83.

519 Ibidem.

${ }^{520}$ PAZ, Octavio. Pedra de Sol. Trad. Horácio Costa. São Paulo: Annablume, 2009. p. 45.
} 
no torso curvo de um escravo, o mundo

é real, tangível, o vinho é vinho,

o pão volta a ter gosto, a água é água,

amar é combater, é abrir portas,

deixar de ser fantasma com um número

a uma prisão perpétua condenado

por um amo sem rosto ${ }^{521 "}$.

A menção à libertação libidinosa prossegue à menção que Paz faz, dentre as várias que compõe o material erótico deste poema, ao romance proibido entre Heloísa e Abelardo. Diante da repressão dos afetos, "melhor o crime", melhor enfrentar a castração do que abdicar a este ato que, para Paz, dentre os atos da liberdade humana, talvez seja o mais genuíno. Ora, a definição clássica de liberdade, em seu sentido aristotélico, afirma que o ser humano é livre apenas se se possibilita o direito ao gozo e à contemplação. Que seria o amor, para Paz, senão a conjunção destes dois princípios?

Se, para Paz, o amor é um composto que abarca, em sua profunda complexidade, estes dois aspectos, podemos afirmar que, enquanto ato de liberdade, ele não pode se abster de conservá-los. Para Byung-Chul Han,

“o homem não nasceu para o trabalho. Quem trabalha não é livre. Para Aristóteles, o homem livre é alguém independente das necessidades da vida e de suas coações. Ele tem à disposição três formas de vida livre: primeiramente a vida que se volta ao gozo das coisas belas, depois, a vida que produz belos atos na polis, e por fim a vida contemplativa, que se conserva na investigação daquilo que não passa, se mantém no âmbito da beleza perene. Segundo isso, são livres os poetas, os políticos e os filósofos ${ }^{522 "}$

521 Ibidem.

522 HAN, Byung-Chul. Sociedade do cansaço. Trad. Enio Paulo Giachini. 2ª ed - Petrópolis, RJ: Vozes, 2017. p. 119. 
Daí que a compreensão de Paz acerca das manifestações de 1968, já trabalhadas por nós aqui, se situe numa espécie de demanda do corpo, ou seja, demanda do corpo por liberdade. Por isso, Paz afirma que Conjunções e Disjunções que

\begin{abstract}
“a história do corpo na fase final do Ocidente é a de suas rebeliões. Não creio que em nenhuma outra época nem em nenhuma outra civilização o impulso erótico tenha se manifestado como uma subversão pura ou predominantemente sexual. Quero dizer: o erotismo é algo mais que uma mera urgência sexual, é uma expressão do signo corpo. Pois bem, o signo corpo não é independente; é uma relação e sempre é um para, frente, contra ou com o signo não-corpo. A rebelião do Ocidente parece indicar que a disjunção entre os signos se tornou de tal forma extrema que sua relação tende a se esvanecer quase que inteiramente ${ }^{523 \prime \prime}$
\end{abstract}

Por isso, o caráter desta demanda expressa em Pedra de Sol é urgente. Paz reconhece na história do Ocidente um desenvolvimento que, graças a uma série de casuísmos e fatores que podemos considerar, em sua natureza, históricos, nos levou a esta extrema disjunção que é agora questionada, salvo as manifestações atuais de recalque, em seu sentido freudiano.

Por isso, em sequência à referência ao amor de Heloisa e Abelardo, Paz fará menção a todos os amores malditos e às suas práticas tabus, como o incesto, a sodomia, "o adultério consumado entre cinzas ${ }^{524 ",}$ etc. Todos estes casos associados às figuras míticas presentes no poema, como Artêmis e Quetzalcóat ${ }^{525}$, bem como às figuras femininas de Maria, Perséfone, Melusina, que nos sugerem que

\footnotetext{
523 PAZ, Octavio. Conjunções e Disjunções. Trad. Lucia Teixeira Wisnik. São Paulo: Perspectiva, 1979. p. 112.

524 PAZ, Octavio. Pedra de Sol. Trad. Horácio Costa. São Paulo: Annablume, 2009. p. 47.

${ }^{525}$ Acerca do erotismo que sua figura suscita, trata-se mais de um mito envolto em um tabu sexual que nos lembra Édipo-Rei de Sófocles. Em Claude Lévi-Strauss ou o novo festim de Esopo, Paz diz que "Tezcatlipoca, deus coxo e senhor de magos e feiticeiros, intimamente associado ao mito dos sacrifícios humanos, tenta Quetzacóatl e leva-o a cometer o duplo pecado de adultério e incesto (Quetzacóatl se embebeda e deita-se com sua irmã). Ao inverso do que ocorre com Édipo, salvador de Tebas ao decifrar o enigma da esfinge, Quetzacóatl é vítima do engano do feiticeiro, e assim perde o seu reino e ocasiona a perda de Tula. Os astecas, que se consideram sempre os herdeiros da grandeza de Tula, representaram outra vez o mito de Quetzacóatl (quero dizer: celebraram-no, viveram-no) no momento da conquista
} 


\begin{abstract}
“a presença mitológica de Vênus espalha-se em todo o poema, de tal forma que se se quisesse atribuir a ela um núcleo central de significações - uma espécie de mínimo denominador comum - que faz com que o poema possa ser lido como um cântico sobre a libertação das pulsões vitais, notadamente as eróticas - seja no sentido extático, de comunhão do eu com o outro, como no sentido abismal, de perda, e consequente terror, do eu no outro ${ }^{526 "}$.
\end{abstract}

A seguir, o poeta envereda por um caminho de linguagem que o conduz à introspecção, na qual vislumbra a tensão existente entre a sua interioridade e a outridade que lateja em relampejos de instante. Ao perscrutá-la, o autor defronta-se com a sua própria identidade. Em seus versos, Paz diz:

\author{
"sigo meu desvario, quartos, ruas, \\ caminho a cegas pelos corredores \\ do tempo e subo e desço seus degraus, \\ suas paredes toco e não me movo, \\ volto onde comecei, busco teu rosto, \\ caminho pelas ruas de mim mesmo \\ sob um sol sem idade, e tu a meu lado \\ caminhas como um rio, como uma árvore ${ }^{527 "}$.
}

O outro é misto de mobilidade (rio) e imobilidade (árvore), mas é deveras impulso vital, às vezes, imperceptível à primeira vista. Heidegger, quando pensa o potencial técnico das câmeras, retêm neste fenômeno que a aceleração da técnica, que nos propicia vislumbrar o crescimento de uma árvore em ritmo acelerado, nos desabita do sentido próprio de sua temporalidade. Como afirmar que o poeta mente acerca do caminhar da

\footnotetext{
espanhola, só que ao inverso. Talvez o mito de Quetzacóatl, caso se consiga decifrar a sua estrutura, possa nos dar a chave dos mistérios da história antiga do México: o fim das grandes teocracias e o princípio das culturas históricas (a oposição entre Teotihuacán e Tula, poderia dizer-se, para simplificar), e a atitude dos astecas diante de Cortés" (Op. Cit, 1993. p. 28).

${ }^{526}$ COSTA, Horácio. Nota do Tradutor In PAZ, Octavio. Pedra de Sol. São Paulo: Annablume, 2009. p. 76.

527 PAZ, Octavio. Pedra de Sol. Trad. Horácio Costa. São Paulo: Annablume, 2009. p. 49.
} 
árvore? Seu ritmo é outro, seu ritmo é o tempo erótico, o tempo do amor, "tempo total onde nada acontece/ afora seu transcurso afortunado ${ }^{528 "}$. O poeta também é a comunhão rítmica com aquilo que canta, como mostramos acerca da simpatia. Dentro do instante amoroso, perdemos a dimensão quantificada dos minutos, pois o tempo que nos abarca é inextenso. Tudo acontece e a nós nada acomete: "(silêncio: passou um anjo neste instante/ extenso como a vida de cem sóis ${ }^{529}$ )". Tal qual o anjo da história de Paul Klee, figura referencial para a imagem dialética em Walter Benjamin, o poeta detém a extensão da história no interior de um instante que detém o transcorrer do tempo e valida à guisa do acontecimento particular à luz da totalidade histórica.

Este instante particular é o único no qual nos apoderamos, realmente, de nossas vidas. Assim como em Pedra do Sol, o poema dedicado a Roman Jakobson, Pasado en claro, demonstra a consciência lúcida do poeta neste instante de coincidência rítmica entre a sua duração interior e a do próprio mundo:

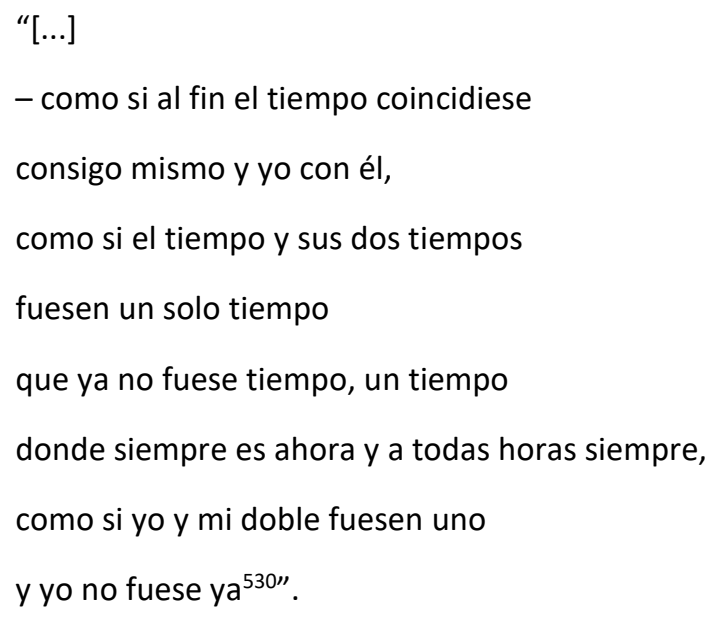

Segundo Jacques Lafaye, este poema é um dos que parecem convergir toda uma tradição filosófica que refletira acerca da natureza da temporalidade. Em sua obra Octavio paz en la deriva de la modernidade, o historiador francês vislumbra, nestes versos, certa influência bergsoniana na maneira em que o poeta afirma apreender o

\footnotetext{
528 Ibidem. p. 51.

529 Ibidem.

530 PAZ, Octavio. Pasado en claro. In In Obras Completas. Vol. VII. Cuidad de Mexico: Fondo de Cultura Económica, 2014.
} 
tempo, onde podemos ver uma associação entre os "dados imediatos da consciência" e o instante poético:

\footnotetext{
“El poeta llegó a grabar este poema; lo enunció con voz apaciguada que atenúa notablemente la tensión del texto escrito. En los versos que acabamos de leer está concentrado a la vez el exilio interior, la soledad del poeta y su quête de la unidad, de lo que él no podía llamar Eternidad (como Charles Péguy) ni el Tiempo Perdido (como Marcel Proust), pero quizás sí el "instanteneísmo" o el "dato inmediato de la consciencia", como Bergson ${ }^{531 " .}$
}

Este caminho da solidão do poeta é um oscilar profundo, entre o momento em que o poeta se percebe em comunhão e aquele em que retorna a si mesmo sozinho. Ainda que, em seus versos, Paz prossiga por esta vereda da introspecção, em seu âmago pulsa a necessidade de se ver reintegrado ao próprio texto, duplo do mundo.

Neste intervalo ensimesmado, tendo percorrido as mortes solitárias de Sócrates, Agamenon, Júlio César, Montezuma, Lincoln, Trostky, todas silenciadas pelo assassinato ou condenados da forma mais vil, todas estas imagens tornam-se cinzas na chama ardente da história:

\footnotetext{
"são chamas

os olhos, e são chamas o que veem,

[...] tudo se queima, o universo é uma chama, arde o mesmo nada que não é nada ${ }^{532 "}$.
}

O que nos leva a questionar: o que subsiste na substância que arde, nos olhos que morrem? Questões similares povoaram a mente de Jorge Luis Borges, como este expressa em sua breve prosa A Testemunha, de 1960:

531 LAFAYE, Jacques. Octavio Paz en la deriva de la modernidade. México: Fondo de Cultura Económica, 2013. p. 61.

532 PAZ, Octavio. Pedra de Sol. Trad. Horácio Costa. São Paulo: Annablume, 2009. p. 55. 
"fatos que povoam o espaço e que chegam ao fim quando alguém morre podem maravilhar-nos, mas uma coisa, ou um número infinito de coisas, morre em cada agonia, a não ser que exista uma memória do universo, como conjecturaram os teósofos. No tempo houve um dia que apagou os últimos olhos que viram Cristo; a batalha de Junín e o amor de Helena morreram com a morte de um homem. O que morrerá comigo quando eu morrer, que forma patética ou perecível o mundo perderá533"?

Quer lembremos das ideias que se passaram na mente de ambos os poetas, quer corroboremos seus esquecimentos, é notório que a metáfora da chama e do fogo permanecem, visto que é esta a simbologia que nos iguala a todos em morte, quando seremos lembrados pelo queimar de uma vela. Para cada alma, a brisa do vento faz flamejar um ponto de luz diferente nos cemitérios. Ocorre que, questionamos, no solipsismo da vida nuclear, a morte também é nuclear, sem comunhão?

Individualizados, os mortos são como fantasmas que não assombram, nem conseguem encontrar os outros:

\footnotetext{
"sua morte é a estátua de sua vida, um sempre estar nada já para sempre, cada minuto é nada para sempre, um rei fantasma rege teus pulsares e teu gesto final, tua dura máscara labora sobre teu mutante rosto: o monumento somos de uma vida não vivida e alheia, nossa por átimos ${ }^{534 \prime \prime}$.
}

533 BORGES, Jorge Luis. Nova antologia pessoal. Trad. Davi Arrigucci Jr, Heloisa Jahn, Josely Vianna Baptista. São Paulo: Companhia das Letras, 2013. p. 71.

534 PAZ, Octavio. Pedra de Sol. Trad. Horácio Costa. São Paulo: Annablume, 2009. p. 57. 
Ao afirmar que a morte é a estátua da vida, o poeta denuncia uma interpretação da primeiro que se subjuga e subordina-se à segunda. Morte e vida devem ser compreendidas como polos em relação, impossíveis de dissociar, complementares, como Paz demonstra em Signos em Rotação. Mas, à medida em que compreendemos a vida como uma realidade cujo destino da morte se interpõe a todos instante, estamos tornando a vida mesma impossível, uma vez que estamos desabitando-a de sua própria presença. José Gaos nos explica que, para Martin Heidegger,

\footnotetext{
“'"el 'ser relativamente a la muerte' como 'correr al encuentro' de la posibilidad lo que hace posible esta posibilidad", es la posibilitación misma de ésta. En suma, ser en relación con la posibilidad que ella es, nos es sino el proceso mismo de la vida como posibilidad de que ésta deje de ser - la posibilidad misma que ella es más radicalmente que nada ${ }^{535 \prime \prime}$.
}

Ora, uma vida definida pela morte tende ao Nada. Por isso, Octavio Paz, leitor de Nietzsche, compreende que o que se dá neste átimo é o que faz a própria vida ser justificada, isto é, o instante em que partilhamos a outridade. À pergunta: "a vida, quando foi nossa de fato?", Paz elabora a seguinte estrofe deste poema contínuo:

\footnotetext{
"de fato, quando somos o que somos?,

a bem pensar não somos, nunca somos

quando sós mais que vazio e vertigem,

caretas e espelho, horror e vômito,

nunca a vida é nossa, a vida é dos outros,

é de ninguém a vida, todos somos

a vida - para os outros, pão de sol,

os outros todos que somos nós todos-,

sou outro quando sou, os atos meus

serão mais meus se forem de nós todos,

para que possa ser hei de ser outro,
}

535 GAOS, José. Introducción a El Ser y el Tiempo de Martin Heidegger. 2ª ed. México: Fondo de Cultura Económica, 2017. p. 68. 
sair de mim e buscar-me entre os outros, os outros que não são se eu não existo, os outros que me dão plena existência, não sou, eu não existo, só há nós, a vida é outra, além, sempre adiante ${ }^{536 \prime}$

Quando atinge a comunhão é que, enfim, o poeta consegue perceber a realização do instante que funda seu mito pessoal, isto é, o átimo de tempo em que participa do Ser de uma maneira única que foi elaborada pelas suas próprias mãos, as mãos que são suas e dos seus outros. Neste intervalo poético, a morte e a vida perdem a oposição que as tenciona e, conjuntas, perfazem um sentido mais pleno à existência. Assim, para Jacques Lafaye, "tanto la protesta de Paz como en la de Heidegger se transluce la nostalgia, o el anhelo, de la Grecia presocrática, de la inmanencia, herencia común de dos lectores de Nietzsche ${ }^{537 "}$. Se há que se compreender a morte neste contexto poético, que seja como "fome de ser", isto é, aquilo que, ao estabelecer um ser-para, complementa sentido a esta vida: "vida e morte/ pactuam em ti, senhora da noite ${ }^{538 " . ~}$

Se o tempo é gestação, isto se deve ao fato de que o período cíclico de cada novo levantar do Sol pressupõe uma queda a cada vez que irrompe no horizonte: despertar é nascer de novo. "Caio sem parar desde haver nascido ${ }^{539 " . ~ S u s p e n s o s ~ d a ~ q u e d a ~ n o ~}$ encontro com o outro, flutuamos na contemplação de nossa própria imagem neste, agora indistinto de nós. Não há identidade ensimesmada, pois a radical heterogeneidade de ser a dissolveu. O que quer que constitua a pessoalidade paziana, é totalmente distinto do sujeito moderno, ponto arquimediano do mundo, onde todas as coisas principiam e morrem. Neste universo em rotação, o mundo começa imageticamente - na imagem do outro. A figura do Sol, então, novamente vem à tona neste final do poema (se é que é lícito chama-lo assim):

\footnotetext{
536 PAZ, Octavio. Pedra de Sol. Trad. Horácio Costa. São Paulo: Annablume, 2009. p. 59.

${ }^{537}$ LAFAYE, Jacques. Octavio Paz en la deriva de la modernidade. México: Fondo de Cultura Económica, 2013. P. 222.

538 PAZ, Octavio. Pedra de Sol. Trad. Horácio Costa. São Paulo: Annablume, 2009. p. 61.

539 Ibidem.
} 


\begin{abstract}
“porta do ser, desperta-me, amanhece,
deixa-me ver o rosto deste dia,

deixa-me ver o rosto desta noite,

tudo se comunica e transfigura,

arco de sangue, ponte de pulsares,

leva-me ao outro lado desta noite,

aonde todos nós somos tu eu,

ao reino dos pronomes enlaçados ${ }^{540 \prime \prime}$.
\end{abstract}

Neste versos, assim como nos versos da estrofe seguinte, Paz exorta ao Sol, "porta do ser" que se abra à sua visão. Esta abertura pode ser compreendida como uma espécie de momento epifânico, onde a transparência nos possibilita que este rosto seja visto e que nos veja, "para a vida encarar até a morte ${ }^{541 "}$. 0 acontecimento poético é um instante de abertura do ser, de desvelamento, onde as coisas, pela linguagem enquanto poiesis, retornam deste manancial mais vívidas e carregadas de sentido. Para Heidegger, em A Origem da obra de arte,

\footnotetext{
"a poiesis é a fala inaugurante do desvelamento do sendo. [...] Em tal narrar se cunham, previamente, para um povo histórico as noções de sua essência, isto é, de seu pertencimento à história do mundo. [...] A própria linguagem é poiesis em sentido essencial. Mas porque a linguagem é aquele acontecimento no qual, a cada vez, o sendo como sendo se abre pela primeira vez para o ser humano, por isso é a poesia, a poiesis em sentido mais restrito, a mais originária poiesis em sentido essencial ${ }^{542 \prime \prime}$.
}

O manancial do ser é aquele que o poeta intenta, a cada novo despertar sob a luz do Sol que se levanta, dia a dia, através do seu fazer, retirar da terra. Contudo, este sabe que jamais a linguagem poderá abarcar a totalidade de seu sentido. Como já explicamos, o poeta distingue-se do místico por não limitar o seu contato com o Absoluto à

\footnotetext{
540 Ibidem. p. 63.

541 Ibidem. p. 65.

542 HEIDEGGER, Martin. A Origem da Obra de Arte. Trad. Idalina Azevedo e Manuel Antonio de Castro. São Paulo. Edições 70, 2010. p. 189.
} 
contemplação silenciosa e imersiva. Tal como o Aedo, o poeta exprime o que vê e o que sente. Porém, diante deste mesmo Absoluto, mesmo o poeta que melhor opera o sentido da poesis na linguagem tem consciência de sua tarefa trágica. Ao tocar este Absoluto, somos por ele absorvidos, mas a linguagem fala pelo poeta e este jamais a expressa de maneira cabal. Sendo assim, a cada vez que fala, inicia uma nova tentativa de expressá-lo, pois aquilo que quer dizer e que, às vezes, o obriga a se calar, é a “indizível presença de presenças ${ }^{543 " . ~ A s s i m ~ c o m o ~ p a r a ~ P a z ~ o s ~ i n s t a n t e s ~ s a ̃ o ~ e x c e p c i o n a i s ~}$ momentos em que o Ser se abre e tudo se complementa, para Heidegger, este instante poético da linguagem é uma clareira onde o aberto se desvela, mas cuja apreensão nunca é cabal, nunca é definitiva, pois só pode se dar no "sendo".

Por esta razão, o poeta possui o desejo constante de sempre retornar a este estado, assim como o amante que sente saudades do amplexo erótico onde tudo se consolida no contato com o outro e o Absoluto se revela prenhe de sentido. Porém, na oscilação entre comunhão e solidão, a segunda sempre nos joga em nós mesmos, novamente, e impede o prosseguir desta caminhada cuja duração nos escapa. Paz finaliza o poema recobrando a atenção, desperto deste instante maravilhoso, onde, como numa revelação divina, compreendeu no seio da existência que somos unos com ela sem deixar de sermos outros:

\footnotetext{
“quero seguir adiante e não posso:

despencou-se o instante noutro instante,

dormi sonhos de pedra que não sonha

e depois de anos e anos como pedras

ouvi cantar meu sangue encarcerado,

como um rumor de luz o mar cantava

e as muralhas cediam uma a uma,

todas as portas desmoronavam

e o sol batia a secas em meu rosto,

abria minhas pálpebras fechadas,

desprendia meu ser de seus limites,
}

543 PAZ, Octavio. Pedra de Sol. Trad. Horácio Costa. São Paulo: Annablume, 2009. p. 65. 
de mim me arrancava, libertava-me

de meu dormir por séculos de pedra

e seu brilhar mágico revivia

um sálix de cristal, um choupo de água,"

Octavio Paz termina Pedra de Sol indicando que este instante pode ser revivido sempre e mais uma vez. Entretanto, o instante será sempre um átimo de tempo, assim como a vida em seu sentido cósmico. O que ordena a raridade deste acontecimento é mais o acaso que um conjunto de regras casuístas capazes de determinar o momento em que ele irá irromper. Assim são o amor, a revolta e também a festa. Quem os rege é o tempo, a orquestrar o vaivém de nossas memórias - das individuais às coletivas, uma vez que este instante, fundado pelo manancial da linguagem, presentificou-se, isto é, tornou-se calendário, fato memorável, possibilidade cíclica de encarnação. Por isso, toda vez que se reinicia a leitura do poema, damos à linguagem, novamente, a chance de se manifestar como poiesis, nesta celebração da palavra que é ritual. Segundo Horácio Costa, um instante consagrado que é também, por sua vez, um momento de equilíbrio:

"El autor de Piedra de Sol plantea la percepción como un acto que se repite y se renueva: su mirada luminosa volverá a la carne de la piedra cíclicamente, para en ella deslindar siempre la misma cosa - un equilibrio real que sólo existe en el momento en que la mirada es fusión. En el instante fugaz en el que el instante se perpetúa ${ }^{544 "}$.

Em suma, a dialética entre abertura e velamento é uma questão que permanecerá, como se verá, em outros poemas de Paz, como Blanco, cuja análise apresentaremos a seguir. O tema do polo amor-erotismo também seguirá presente, cujo cotejo nos auxiliará a obra La llama doble, ensaio que Paz dedicou exclusivamente a esta temática.

${ }^{544}$ COSTA, Horácio. Piedra de Sol: el título in Mar Abierto: ensayos sobre literatura brasileña, portuguesa e hispanoamericana. Ciudad de México: Fondo de cultura económica, 2000. p. 359. 


\section{A experiência amorosa no poema Transblanco:}

O poema Blanco data de 1966, quase dez anos após a publicação de Piedra de Sol. Assim como o primeiro, este poema também possui uma estrutura mandálica, com a diferença de que, em Blanco, temos uma predominância de elementos menos tradicionais, do ponto de vista da tradição poética ocidental, como a disposição heterogênea dos versos na página, possibilitando que a leitura leve em consideração os espaços em branco que figuram no interior da sua disposição estrófica. Para Haroldo de Campos, cuja tradução do poema será por nós estudada aqui, Blanco é uma tentativa de transformar o tempo em espaço, isto é, enquanto expressão metafórica do mesmo. No caso, o poema se vale de recursos como a justaposição e a simultaneidade para nos dar uma visão imagética da temporalidade que o tradutor chama "agoridade" e que Paz simplesmente chama "ahora", formando um "cosmograma plurisensível".

Em um de seus breves ensaios críticos, El pensamiento en blanco, de 1969, Octavio Paz parte de um diagnóstico presente em boa parte de suas outras obras: vivemos o esgotamento de uma imagem de tempo que tem como um de seus efeitos o esgotamento de certa ideia de arte, assim como seu objeto. Ainda que reconheça o surgimento de novos modelos artísticos e novas ferramentas estéticas que pretendem retomar o ideal vanguardista de embaralhamento arte-vida, o poeta levanta a questão se, também, outro tipo de arte, que atenda a necessidades tão vitais quanto o prazer, a felicidade e a revolta, também não seria necessária. Em suma, “¿cómo no imaginar otro arte, en el polo opuesto, destinado a satisfacer una necesidad no menos imperiosa: la meditación y la contemplación solitarias?". Para Paz, esta arte não seria uma recaída na idolatría da "cosa artística545" que permeou a estética em seus últimos duzentos anos, tampouco reforçaria a estética destrutiva de certas vanguardas artísticas, como o Dadá, "sino que vería en el cuadro, la escultura o el poema, un punto de partida ${ }^{546 " . ~ U m ~ p o n t o ~}$ de partida até a presença e seu jogo tensionado com a ausência, em vista daquilo que o tantrismo chama a "sabedoria suprema" (Prajñaparamita), outra margem ou vacuidade, em suma, volta dos tempos ou regresso à unidade. Talvez um ensaio ou uma expressão

\footnotetext{
545 PAZ, Octavio. El pensamiento en blanco In Obras Completas IV, Los privilegios de la vista: Arte Moderno universal, Arte de Mexico. México: Fondo de Cultura Económica, 2014, p. 53.

546 Ibidem.
} 
do que pode ser este ponto de partida, em busca do pensamiento en blanco, seja o próprio poema que leva este nome.

Em primeiro lugar, acerca de Blanco, devemos considerar que em seu corpo, "o hinduísmo é a intertextualidade, vide a epígrafe "By the passion the world is bound/ by passion it is realeased" de Havajra tantra ${ }^{547 "}$. Por esta razão, algumas das considerações de El pensamiento en blanco aderem-se ao poema, visto que este texto figura como prefácio à primeira exposição de arte tântrica, realizada em Paris, no ano de 1970, cujas pinturas consistiam em exibições encarnadas do corpo. Ao inserir esta tradição no centro do poema, Paz faz do texto corpo e do corpo escritura. Mas, também podemos afirmar que a presença do budismo não é menor, destarte sua diferença. Em um comentário acerca de Blanco, datada de sua vinda à Universidade de São Paulo para uma leitura conjunta com Transblanco - transcriação deste poema empreendida por Haroldo de Campos - Octavio Paz afirma que "este poema, mais do que por um princípio e um fim, está regido [pela] figura do mandala. O mandala é um objeto de devoção [...] da Índia, do Tibete, do budismo tibetano sobretudo, do Nepal também ${ }^{548 " .}$. Em sua estrutura, vislumbramos uma divisão quaternária, onde podemos ver os quatro elementos da natureza, bem como as faculdades essenciais das filosofias ocidental e oriental, a saber, sensação, percepção, imaginação e entendimento. Trata-se de um poema que volve sua atenção para si mesmo, sobre seu próprio engendrar-se caminhante, onde, intertextualmente, converte-se em objeto erótico através da presença da mulher, à qual, para Paz, "às vezes é linguagem, às vezes é sensação ou percepção, e às vezes é simplesmente iluminação ${ }^{549 "}$. A sua estrutura mandálica é o que nos possibilita ler suas analogias de forma regressiva ao ponto de partida elucidado - o branco, ao instante de silêncio que se encontra no centro de cada mandala e no antes e depois da declamação poética. Percorrer pelo poema este caminho de signos nos leva a retornar ao corpo, como Paz explica:

\footnotetext{
${ }^{547}$ COSTA, Horácio. O traduzir como necessidade e como projeto In MACIEL, Maria Esther (Org.) A palavra inquieta: homenagem a Octavio Paz. Belo Horizonte: Autêntica, 1999. p. 32.

${ }_{548}$ Comentário de Octavio Paz sobre o poema "Blanco" In PAZ, Octavio; CAMPOS, Haroldo. Transblanco. São Paulo: Siciliano, 1994. p. 87.

549 Ibidem. p. 88.
} 


\begin{abstract}
"Cada vuelta en la espiral de las analogías nos regresa al punto de partida y, simultáneamente, nos enfrenta una perspectiva desconocida: la imagen del cuerpo como peregrinación nos devuelve a la imagen del cuerpo como escritura. Escribir o leer es trazar o descifrar signos, uno detrás de otro: caminar, peregrinar. Por su naturaleza misma, la escritura va siempre más allá de ella misma; lo que buscamos no está en la escritura, excepto como señal o indicación: la escritura se anula y nos dice que aquello que buscamos está (es) allás50".
\end{abstract}

Caminhos dos signos, ao final deste corpo textual, haverá sempre um novo signo, a fazer girar a estrutura, ciclicamente. Talvez o que Paz espere da leitura de Blanco seja similar ao desprendimento ou à vertigem evocada pelas obras de arte tântricas a que dedicou este ensaio. Afora estas características, poderíamos nos alongar acerca dos efeitos produzidos pelos recursos tipográficos utilizados pelo autor, mas nos deteremos agora no conteúdo que, ainda que indissociável destas escolhas, nos revelam opções que sugerem a seguinte leitura.

Desde a primeira página do poema, verificamos que o sentido dos versos pode ser compreendido por uma leitura que se permite, linha a linha, horizontalmente, ou abrangendo as colunas verticais que a disposição dos versos constrói ou, num terceiro sentido, pela via diagonal, entrecruzando as colunas. Os versos de abertura do poema são:

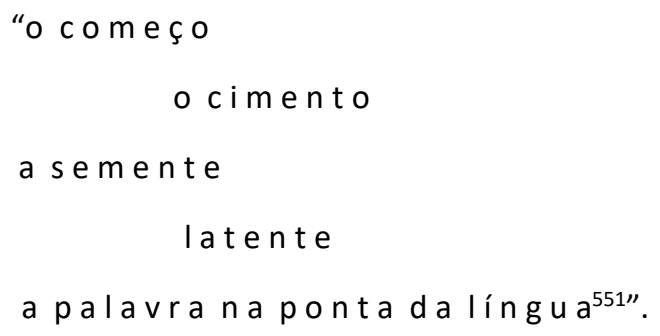

550 PAZ, Octavio. El pensamiento en blanco In Obras Completas IV, Los privilegios de la vista: Arte Moderno universal, Arte de Mexico. México: Fondo de Cultura Económica, 2014, p. 59.

551 PAZ, Octavio; CAMPOS; Haroldo. Transblanco. São Paulo: Siciliano, 1994. p. 61. 
Desde o espaçamento entre as caracteres até o que separa as palavras, Transblanco dá seu tema logo de início, afirmando o fundo branco da página num ritmo pausado entre os versos, associando, de prima, este intervalo à respiração com que entoamos cada verso. Logo no primeiro verso, metalinguístico, o poema demonstra que sua verve será um voltar-se sobre si mesmo: seu começo é "o começo". No segundo, seu elemento concreto, o cimento, é contrastado pelo terceiro verso, pelo elemento móvel: a semente. Que seria a semente em sua latência senão o período em que esta se elabora para assumir a existência em sua forma plena e cabal. Por fim, no quinto, temos que esta germinação, que o que está encubado, encapsulado no vegetal que brota, é a palavra - sobretudo, a palavra poética. O gestar de uma semente é a metáfora do processo de elaboração poética que aqui se inicia. Ademais, de uma forma generalizada, acerca da primeira página de Transblanco, poderíamos formar os segmentos de sentido como rotacionais em relação ao verso principal: "a palavra", caracterizada pelo poeta como inaudita, inaudível, grávida, nula, sem idade, inocente, promíscua, sem nome, sem fala. Estas características, aparentemente, contraditórias entre si, nos revelam de antemão a sua natureza selvagem e analógica. Esta palavra que periga começar é uma natureza amorfa, sem conteúdo prévio, em pleno vir a ser: está aberto o poema - ou está aberto o Ser?

Adiante, temos os versos

"Sobe de desce,

Escala de escapulário,

A linguagem desabitada ${ }^{552 "}$.

Desabitada ou por habitar, a linguagem, em seu vaivém demarcado na escala de escapulário já tonifica a sacralidade da palavra que engatinha. Adiante, o latejar da lâmpada, o Girassol - sol carbonizado, sugerem a predominância da cor amarela neste início de poema, em uma trajetória que transpassará o vermelho, o verde e o azul. Em Transblanco, entretanto, todas as cores orbitam a cor alva, como uma representação

552 Ibidem. p. 61. 
imagética da ausência ou mesmo do Nada, daí a segunda epígrafe desta obra seja a frase

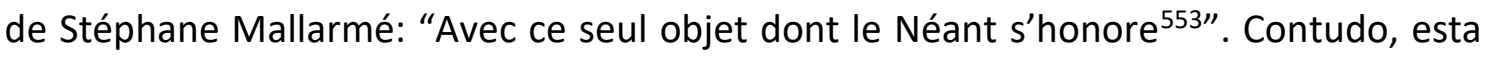
operação sinestética onde as cores complementam o sentido dos versos nos remete, para além de Mallarmé, a Rimbaud, em seu poema "Vogais", onde temos, desde o primeiro verso: “A negro, E branco, I rubro, U verde, O azul, vogais/ Ainda desvendarei seus mistérios latentes:" 554 . Em Paz, as cores amarelo, vermelho, verde, azul e branco, por sua vez, representarão os cinco elementos tradicionais que fazem girar o mandala. Para Manuel Ulacia, estes elementos

\footnotetext{
"son la proyección en el mándala de las cuatro diosas: Fuego (Pãndarã), Agua (Mãmaki), Tierra (Locaña) y Aire (Tãrã). El quinto elemento, espacio, se funde con la consciencia (vijñãna) en el centro. [...] Estas divinidades son no sólo fuente de emancipación sobre el cuerpo central, sino también el contrapunto de las cinco "sabidurías transcendentales", que son equivalentes a "Ios cinco diablos" que "yacen en la raíz de la existencia fenomenal ${ }^{555 " .}$
}

A luz amarela é uma luz que incide sobre o corpo, "sob a pele da penumbra", e que o colocará no jogo de ausência e presença com seu correlato, o signo não-corpo. Segundo Ulacia, é possível acompanhar neste poema o movimento das ideias expressas em Conjunções e Disjunções.

Adiante, o poema recebe uma coloração erótica, dividido em duas colunas, onde vemos os seguintes versos na da esquerda:

\footnotetext{
"no muro a sombra do fogo

no fogo tua e minha sombras
}

\section{o fogo te ata e desata}

\footnotetext{
553 Ibidem. p. 34.

${ }^{554}$ RIMBAUD, Arthur. Vogais In Rimbaud Livre. Trad. Augusto de Campos. São Paulo: Perspectiva, 2013. p. 36.

555 ULACIA, Manuel. El arbol milenário: Um recorrido por la obra de Octavio Paz. Barcelona: Galaxia Gutenberg/ Círculo de Lectores, 1999. p. 341.
} 


\section{Pão Graal Áscua}

\section{Mulher}

teu riso - nua

entre os jardins da chama ${ }^{556 \prime}$

Um dado biográfico neste episódio do poema não seria gratuito. Os anos de sua escrita, marcadamente os anos em que Paz esteve, de forma majoritária, na Índia, são os anos em que conhece Marie José, sua mulher, com quem viverá uma experiência amorosa refletida não apenas em seus poemas, mas em suas considerações ensaísticas. Para Manuel Ulácia, "casi todos los poemas que escribe en esta década tienen como tema la experiencia amorosa, la cual, a través de mitos y creencias religiosas y filosóficas orientales, es proyectada sobre un orden cósmico ${ }^{557 ”}$. Já os versos da coluna direita, gravados em vermelho, são os seguintes:

\footnotetext{
"chama rodeada de leões

leoa no círculo das chamas

alma animando sensações

fruto de fogos-de-bengala

os sentidos se exabrem

na noite magnética ${ }^{558 "}$.
}

E finalizam num verso, situado na coluna central, com a passagem: "Paixão de brasa compassiva". Convém explorar aqui a figura da chama, a "lição do fogo", para usarmos uma expressão de Maria Esther Maciel ${ }^{559}$.

Para Manuel Ulacia, estes versos são aqueles que melhor exploram o princípio tântrico exposto na epígrafe pela citação do Hevajra Tantra. Para ele, é precisamente

\footnotetext{
556 PAZ, Octavio; CAMPOS; Haroldo. Transblanco. São Paulo: Siciliano, 1994. p. 64.

557 ULACIA, Manuel. El arbol milenário: Um recorrido por la obra de Octavio Paz. Barcelona: Galaxia Gutenberg/ Círculo de Lectores, 1999. p. 226.

558 PAZ, Octavio. Ibidem. p. 64.

559 Cf. MACIEL, Maria Esther. Lição do fogo In Voo Transverso: Poesia, Modernidade e Fim do Século XX. Rio de Janeiro: Sete Letras, 1999.
} 
aquí que "la idea del epígrafe, "By passion the world is bound, by passion too it is released" [...] se presenta aquí en la columna izquierda, justo antes de la consumación: "el fuego te desata y anuda ${ }^{560 " . ~ O ~ f o g o, ~ c o m o ~ a ~ l u z ~ d a ~ l a ̂ m p a d a, ~ p r o d u z ~ o ~ v i s l u m b r e ~ d o ~}$ corpo e projeta a sombra dos amantes na parede. Os movimentos do despir-se são conduzidos pela paixão, duplo do fogo, a transfigurar a amante em alimento espiritual: Pão (alimento para o corpo), Graal (alimento espiritual e sagrado), Áscua (alimento à chama). Neste instante, Paz chama o seu outro pelo nome, grafado em maiúsculo, "Mulher". Em outros ensaios, Paz já se referira a esta imagem da mulher como alimento supremo. Em Conjunções e Disjunções, o poeta já dissera que a imagem da jovem despida

\footnotetext{
"é a encarnação de uma imagem que aparece na poesia de todos os tempos: o corpo da mulher como altar, mesa viva coberta de frutos vivos, adoráveis e terríveis. Novalis disse que a mulher é o alimento corporal mais elevado: não é também isso que diz, só que carnal e literalmente, o rito tântrico? Sede e fome de comida sagrada, festim de nossa mortalidade, eucaristia ${ }^{561 "}$.
}

Daí a tríade Graal-Pão-Áscua, onde o encontro com o outro é o instante de comunhão. $\mathrm{O}$ ato amoroso é aquele através do qual o poeta redescobre a força do mundo: a que a religião pretendeu canalizar num corpo doutrinário metafísico, para não dizer burocrático. Trata-se de uma força que brota da delicadeza e da sensibilidade, do processo perceptivo que estes versos escondem, mas cuja culminância relatam. Em Poesia de solidão e poesia de comunhão, Octavio Paz inclusive questiona: "Será preciso dizer que essa força, alternadamente sagrada ou maldita, é a do êxtase, da vertigem, que brota como um fascínio no cume do contato carnal ou espiritual ${ }^{562 "}$ ? Nesta relação, onde os "sentidos se exabrem na noite magnética", pois como polos gravitacionais, os amantes se atraem, "o homem e a mulher tocam o absoluto563". Neste ato, a comunhão

\footnotetext{
560 ULACIA, Manuel. Ibidem. p. 343.

561 PAZ, Octavio. Conjunções e Disjunções. Trad. Lucia Teixeira Wisnik. São Paulo: Perspectiva, 1979. p. 73.

562 Id. Poesia de Solidão e Poesia de Comunhão In A Busca do Presente. Trad. Eduardo Jardim. Rio de Janeiro: Bazar do Tempo, 2017. p. 23.

563 Ibidem.
} 
é a reintegração do amante ao todo, uma vez que seu sujeito-objeto do desejo é, por sua vez, o duplo do cosmo.

A imagem da chama é cheia de significações. Para Maria Esther Maciel, o uso que Octavio Paz faz desta metáfora a coloca como conceito operacional em um de seus últimos ensaios, A Dupla Chama. Neste ensaio,

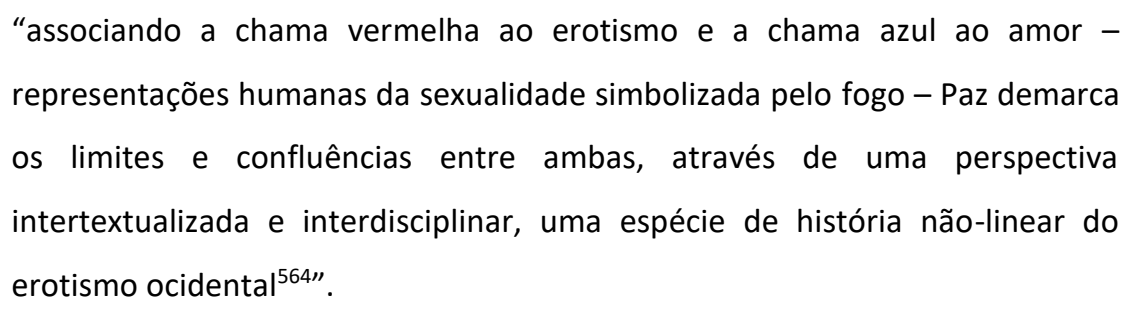

Além disto, para a autora, podemos interpretar este ensaio de Paz como um manifesto escrito por um poeta em defesa da sensibilidade. Demandas de um poeta cuja preocupação maior é, como exposta em Transblanco,

\author{
“Falar \\ Enquanto os outros trabalham \\ É polir ossos,
}

Aguçar

Silêncios

Até à transparência,

À ondulação,

Ao corusqueio,

Até à água: ${ }^{565 ”}$

A imagem corpo erótico para Paz, a nosso ver, é derivada de uma figura mais ampla, a do tu. Graças a essa extensão, a chama torna-se correlata do rio: água e fogo são

\footnotetext{
${ }^{564}$ MACIEL, Maria Esther. Lição do Fogo In Voo transverso: Poesia, Modernidade e Fim do Século XX. Rio de Janeiro: Sete Letras, 1999. p. 109.

565 PAZ, Octavio; CAMPOS; Haroldo. Transblanco. São Paulo: Siciliano, 1994. p. 67.
} 
metáforas do corpo. O apagamento das contrariedades, operado no interior da transparência, possibilita ao poeta cantar, nos próximos versos: "os rios do teu corpo" (coluna esquerda); “o rio dos corpos" (coluna direita). O par fogo-água move o paradoxo das imagens, dissolvidas no caldo da palavra poética, quando um corpo adentra outro, isto é, quando dois fundem-se no amplexo amoroso e anulam os regimes de diferenciação temporal:

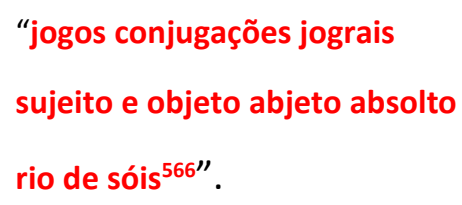

O encadeamento aliterativo deste verso, escrito em fonte vermelha, pertencente à coluna direita, aponta justamente para o que dizíamos, isto é, a indistinção de nossa identidade em relação ao outro. Essa indistinção opera num plano ontológico que nos possibilita conceber rio onde sóis correm como correnteza, operando um sentido. A indistinção entre o eu e tu também se mostra alteração radical de nossa consciência:

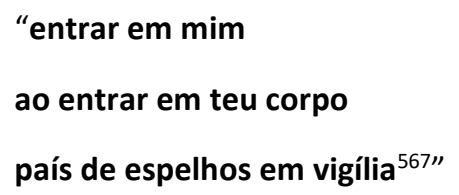

A imagem da transparência também nos remete à já explorada imagem da gema surrealista. Aquela através da qual conseguimos nos ver em seu reflexo, mas, de forma refratária, percebemos as luzes que perpassam o seu interior. O amplexo amoroso opera no interior de uma transparência que é o que, finalmente, "resta ao fim de tudo ${ }^{568 " . ~}$ Outrossim, para Foucault, em relação ao ato amoroso

\footnotetext{
566 Ibidem. p. 68

567 Ibidem.

568 Ibidem.
} 


\begin{abstract}
"sob os dedos do outro que nos percorrem, todas as partes invisíveis de nosso corpo põem-se a existir, contra os lábios do outro os nossos se tornam sensíveis, diante de seus olhos semicerrados, nosso rosto adquire uma certeza, existe um olhar, enfim, para ver nossas pálpebras fechadas. 0 amor, também ele, como o espelho e como a morte, sereniza a utopia de nosso corpo, silenciaa, acalma-a, fecha-a como se numa caixa, tranca-a e a sela. É por isso que ele é parente tão próximo da ilusão do espelho e da ameaça da morte; e se, apesar dessas duas figuras perigosas que o cercam, amamos tanto fazer amor, é porque no amor o corpo está aquij ${ }^{569 " .}$
\end{abstract}

Este olho que se volta às pálpebras fechadas talvez seja o que Paz se refere, poeticamente, como os espelhos em vigília, pois nos remetem, certamente, a uma percepção que se dá no ato da própria sensação, no contato com o corpo do outro.

Ademais, a fusão da percepção à imaginação, do entendimento à sensação expressam-se no entrelaçamento das duas quadras neste trecho ${ }^{570}$ :

\author{
Me vejo no que vejo \\ como entrar por meus olhos \\ em um olho mais límpido \\ me olha o que eu olho
}

\author{
é minha criação isto que vejo \\ perceber é conceber \\ águas de pensamento \\ sou a criatura do que vejo ${ }^{571}$.
}

Este jogo de espelhos é o baile das nossas faculdades e a fundação de referências concretas no mundo, permeado e transpassado por seus polos magnéticos, respectivamente, o eu e o tu. Este exercício da linguagem culmina na dissolução da própria subjetividade e da exortação de Eros neste diário de viagem rumo à Transparência. Neste caso, a única forma de traduzir esta presença do amor -

\footnotetext{
569 FOUCAULT, Michel. O corpo utópico, As heterotopias. Trad. Salma Tannus Muchail. São Paulo: N-1 Edições, 2013. p. 16.

570 Quadras que foram, cabe dizer, musicadas por Marisa Monte em seu álbum Barulhinho Bom de 1996 e que, por conta disso, colaboraram para uma maior difusão de Tramsblanco no Brasil.

571 PAZ, Octavio; CAMPOS; Haroldo. Transblanco. São Paulo: Siciliano, 1994. p. 68.
} 
“o amor louco, o amor verdadeiro, eleição livre de um ser único, insubstituível, o amor como foi inventado no Ocidente cristão; o amor encarnado, no entanto, no imaginário oriental do erotismo tântrico, o amor como ato e como rito: rito do presente, rito da presença, rito de regresso ao princípio $^{572 "}$

- ainda é a linguagem, intentando ser expressão deste Absoluto convertido em instante. Por que esta correlação entre instante erótico e instante poético? Ora, para Paz, "el erotismo es sexualidad transfigurada: metáfora. El agente que mueve lo mismo al acto erótico que al poético es la imaginación ${ }^{573 \prime}$.

Ora, para Paz o ato erótico não se limita meramente ao sexo. Há nele todo um invólucro que constitui, propriamente, o erotismo. Nesta mesma obra, ele afirma que, em La recherche de Proust,

\footnotetext{
"cuando Swann y Odette hablaban de "faire catleya" no se referían simplemente a la copulación; Proust señala: "aquella manera particular de decir hacer el amor no significaba para ellos exactamente lo mismo que sus sinónimos". El acto erótico se desprende del acto sexual: sexo es otra cosa. [...] Sexo, erotismo y amor son aspectos del mismo fenómeno, manifestación de lo que llamamos vida ${ }^{574 "}$.
}

Também para Roland Barthes, esta correlação parece sugerida. Quando este pensa o "abraço erótico", nos afirma que "o gesto do abraço amoroso parece realizar por um momento, para o sujeito, o sonho de união total com o ser amado ${ }^{575 ” . ~ E s t a ~ u n i a ̃ o ~ t o t a l ~}$ é o que o francês chamará de "transbordamento", onde nos sentimos unidos ao outro como um vínculo nosso com a totalidade. Uma vez que este instante passa, somos impelidos a busca-lo, novamente, na necessidade da supressão de uma carência originária, presente em todos os seres pós-uterinos, após sua Queda no mundo e na

\footnotetext{
572 GIRAUD, Paul Henri. Octavio Paz: caminho para a transparência. Trad. António Teixeira. Lisboa: Instituto Piaget, 2002. p. 322.

573 PAZ, Octavio. La Llama Doble. Barcelona: Seix Barral, 2001. p. 12.

574 Ibidem. p. 15.

575 BARTHES, Roland. Fragmentos de um discurso amoroso. Trad. Hortênsia dos Santos. São Paulo: Editora Unesp, 2018. p. 27.
} 
solidão: "o transbordamento existe e vou querer sempre fazê-lo voltar: através de todos os meandros da história amorosa, teimarei em querer reencontrar, renovar, a contradição - a contração - dos dois abraços ${ }^{576 ", ~ a ~ s a b e r, ~ o ~ m a t e r n o ~ e ~ o ~ g e n i t a l ~(e m ~ s e u ~}$ sentido freudiano). Chamamos a esta tríade, sexo-erotismo-amor, de sequência de invólucros pois há, entre elas, uma relação dinâmica que é hierárquica. Para Paz, o mais primitivo dos três atos é o sexo, uma vez que instintivo e animal; já o erotismo depende de nossa capacidade imaginativa, é como se nossa fabulação operasse sobre o ato sexual, numa atividade em que a função poética da linguagem se encarna em gesto; e por fim, o amor, cuja definição abarca um universo mais complexo e cujo aprofundamento se faz necessário.

Em primeiro lugar, devemos compreender que Paz define o erotismo como "sede de outridade", isto é, a demanda pelo ato erótico reside na nossa natural necessidade de superarmos nossa condição solitária. No mais, pensando em Bataille, Paz afirma que os signos eróticos destroem a significação, pois o erotismo transcende a comunicação e rompe com o continuísmo da linearidade temporal:

\footnotetext{
“a dialética própria do prazer - dom e possessão, desejo e gasto vital - confere a esses signos um sentido contraditório: são a família, a ordem, a continuidade e são também o único, o extravio, o instante erótico que rompe a continuidade. Os signos eróticos destroem a significação - queimam-na e transfiguram-na: o sentido regressa ao ser. E do mesmo modo o abraço carnal, ao realizar a comunicação, a anula. Como na poesia e na música, os signos já não significam: são. O erotismo transcende a comunicação ${ }^{577 " \text {. }}$
}

O amor, por sua vez, depende de uma sorte de fatores e predisposições ainda mais rebuscadas. Quanto à formação deste sentimento, Paz dá destaque ao "encontro" como o evento - fora do tempo - em que nos sentimos apaixonados. Neste evento, uma vez

\footnotetext{
576 Ibidem. p. 28.

577 PAZ, Octavio. Claude Lévi-Strauss ou o Novo Festim de Esopo. Trad. Sebastião Uchoa Leite. São Paulo, SP: Ed. Perspectiva, 1993. p. 95.
} 
que do tempo somos lançados, revela-se um movimento de uma conjunção de dois termos contraditórios: predestinação e eleição (livre-escolha):

\footnotetext{
"La idea del encuentro exige, a su vez, dos condiciones contradictorias: la atracción que experimentan los amantes es involuntaria, nace de un magnetismo secreto y todopoderoso; al mismo tiempo, es una elección. Predestinación y elección, los poderes objetivos y subjetivos, el destino y la libertad, se cruzan el amor. El territorio del amor es un espacio imantado por el encuentro de dos personas ${ }^{578 "}$.
}

Podemos afirmar que a noção de encontro que Octavio Paz opera é um conceitoimagem de extração surrealista. Para ele, os poetas surrealistas, dentre os quais André Breton, haviam discernido na natureza do encontro erótico, o encontro fortuito, o coup de foudre, no interior do "instante elétrico". Para Paz,

\footnotetext{
"el encuentro precede a la elección y en el encuentro lo fortuito parece determinante. Breton advirtió con perspicacia que el encuentro está constituido por una serie de hechos que acaecen en la realidad objetiva, sin que aparentemente los guíe designio alguno y sin que nuestra voluntad participe en su desarrollo ${ }^{579 \prime \prime}$.
}

De onde Breton expõe o conceito mais importante a operar acerca das relações amorosas e eróticas no surrealismo: o "acaso objetivo", cujo significado é "una forma de la necesidad exterior que se abre camino en el inconsciente humano ${ }^{580 "}$. Assim como boa parte das ideias de Paz, trata-se de um material que contém em si um de seus princípios analógicos, pois é um conceito que abarca em seu interior dois termos contrários. Por esta razão, acaso objetivo também poderá ser compreendido como "acidente necessário" e esta conjunção de contrariedades o fará abordar, adiante, um

\footnotetext{
${ }^{578}$ PAZ, Octavio. La Llama Doble. Barcelona: Seix Barral, 2001. p. 35.

579 Ibidem. p. 146.

580 Ibidem. p. 147.
} 
tema dos surrealistas: o saber-se enamorado, ou seja, "el saberse el centro de un tejido de coincidencias, señales y correspondencias ${ }^{581 "}$.

De forma similar, Roland Barthes definirá o encontro erótico como o "tempo feliz que se seguiu imediatamente ao primeiro arrebatamento, antes que nascessem as

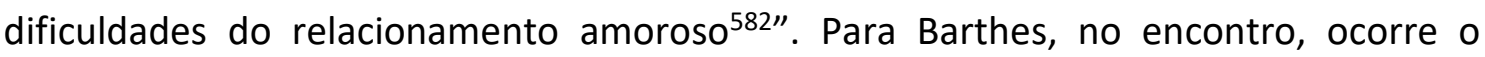
maravilhamento de termos encontrado alguém cuja afinidade e simpatia nos põe em consonância. Saber-se enamorado

\footnotetext{
“é uma descoberta progressiva [...] das cumplicidades e intimidades que vou poder manter eternamente (penso nisso) com um outro, prestes a tornar-me, desde então, "meu outro": estou todo voltado para essa descoberta (tremo só em pensar), ao ponto de transformar em amor toda curiosidade intensa sobre um ser encontrado. [...] O Encontro faz com que o sujeito apaixonado sinta a vertigem de um acaso sobrenatural: o amor pertence à ordem (dionisíaca) do Lance de dados ${ }^{583 \prime \prime}$.
}

$E$, para Paz, se sentir apaixonado é resultado da percepção ou da sensação? Se interpretarmos o amor como um sentimento, e este o é, devemos considerar que o processo que vai das primeiras reações fisiológicas, como o nervosismo, o tremor, o "frio na barriga", até a tomada de consciência, até o momento em que se torna afirmativo para nós mesmos - para, enfim, poder se tornar afirmativo ao outro - que estamos apaixonados, é um processo de maturação cuja duração também nos escapa? Onde reside a fronteira da sensação para a percepção de si, neste caso? Ora, se partirmos do pressuposto que o apaixonar-se ocorre no interior de um regime de temporalidade - o instante - movido pelo encontro (através do acaso objetivo), podemos, certamente, afirmar que, assim como no interior do ato poético, como Octavio paz bem nos mostra em Blanco, percepção e sensação se encontram fundidas. Ou seja, não há uma ruptura de um estágio a outro, uma vez que a diferenciação é uma variação derivativa, tal como

\footnotetext{
581 Ibidem.

582 BARTHES, Roland. Ibidem. p. 137.

583 Ibidem. p. 139.
} 
o processo da atração erótica ao amor. Portanto, trata-se de uma distinção de grau, em que o "tomar consciência" do próprio sentimento pressupõe uma epistemologia dos próprios afetos que é similar à forma como percebemos o tempo, visto que estamos lidando com um tipo de sentimento que desestabiliza a razão. Barthes, ao afirmar que, na progressiva tomada de consciência do sentimento amoroso - em nossa constituição narrativa interna - somos impelidos a projetar eternamente intimidades, cumplicidades e afinidades. Porém, podemos considerar que estamos, com isto, projetando estes laços no agora, pois o amor nada é senão um projeto do dia presente, este além-tempo que é aqui. Similarmente, para Octavio Paz, o amor nos leva além disso: é uma resposta diante do inefável mistério da morte. Se o lêssemos como a um heideggeriano, poderíamos dizer que o Amor é um cuidado que se estabelece acerca do Dasein. Em La llama doble, ele diz que

\footnotetext{
“por ser tiempo y estar hecho de tiempo, el amor es, simultáneamente, consciencia de la muerte y tentativa por hacer del instante una eternidad: [...] es una victoria contra el tiempo, un vislumbrar el otro lado, ese allá que es un aquí, en donde nada cambia y todo lo que es realmente $e s^{584 \prime \prime}$.
}

Paz finaliza esta obra afirmando que o amor é uma distensão do tempo, através do qual estira os minutos e os alarga como séculos. A nomeação deste tempo não poderia ser outra, já estava anunciada desde suas obras anteriores: é o instante: "la percepción de todos los tiempos en uno solo, de todas las vidas en un instante ${ }^{585 \prime \prime}$, por meio do qual vislumbramos o mundo no intervalo de um pestanejo.

Convém esclarecer que, ainda que reconheça a relação amorosa homossexual, como já o fizeram também em outros ensaios, como Sor Juana Inés de la Cruz, o modelo padrão das reflexões de Octavio Paz voltam-se, sobretudo, para a relação heteroafetiva, o que o leva a pensar, sob a ótica masculina, nos papéis da mulher no interior de um relacionamento, principalmente o da liberdade. Por isso, nesta obra, Paz se proporá a pensar no amor como ato em que, para sê-lo, deve pressupor a liberdade de escolha

\footnotetext{
${ }^{584}$ PAZ, Octavio. La Llama Doble. Barcelona: Seix Barral, 2001. p. 213.

585 Ibidem. p. 221.
} 
feminina. Partindo de certa tradição liberal, Paz valoriza o papel da livre-eleição e sugere seu reconhecimento histórico acerca das questões contemporâneas aos movimentos feministas que, no momento da escrita desde ensaio, passava por sua terceira onda. Paz diz: "Todo es prueba, una vez más, que la emergencia del amor es inseparable de la emergencia de la mujer. No hay amor sin libertad femenina ${ }^{586 "}$. Ademais, o amor pode ser compreendido como ato de reconhecimento da pessoa querida, onde reconhecer significa confessar nossa própria dependência em relação ao outro, mas num sentido que abarque o paradoxo imprescindível a toda relação amorosa: aquela que

"reside en que este reconocimiento es voluntario: es acto libre. Reconocimiento, asimismo, en el sentido de confesar que estamos ante un misterio palpable y carnal: una persona. [...] es una apuesta que nadie está seguro de ganar porque es una apuesta que depende de la libertad del otro ${ }^{587 \prime \prime . ~}$

Esta aposta vital, este reconhecimento leva-o à sua reflexão acerca do ciúme. Apesar de reconhecer a sua inevitabilidade, Paz afirma que o ciúme doentio, obsessivo, merece combate e, neste sentido, a sua crítica se afina com a de Roland Barthes, para quem o ciúme também apenas nos leva ao sofrimento. Entretanto, sofremos de ciúme por sermos, absurdamente, comuns.

Voltando a Transblanco, convém questionar: se este poema expressa uma imagem de tempo, cujo correlato é "imagem de mundo", como ele configura este universo? Sabemos que, para Paz, Blanco foi um poema escrito com o objetivo de, dentre outros, espacializar o tempo na página. Contudo, a própria noção se espaço sofre os efeitos do jogo de aparição e desaparição. Após estar imantado pelos elementos, o poeta é jogado na dor da aridez do caminho:

\footnotetext{
"A terra é linguagem calcinada

Há puas invisíveis, há espinhos
}

\footnotetext{
586 Ibidem. p. 73.

587 Ibidem. p. 125.
} 
Nos olhos ${ }^{588 \prime}$

Sua sensação, há pouco absorvida pelo instante erótico, devolve-lhe violentamente ao mundo pós-Queda adâmica, onde um sol, que "não tem corpo nem cara nem alma" e, onipresente, "a todos esmaga ${ }^{589 " . ~ A ~ d e s o l a c ̧ a ̃ o ~ d e s t e s ~ v e r s o s ~ n o s ~ e n c a m i n h a m ~ a ~ u m ~}$ perscrutar dos elementos do espaço que o poeta vivera há pouco: a terra e o céu. Porém, o mesmo espaço se desvanece. As noções clássicas para espaço e para tempo sofreram uma radical transformação, a ponto de fazer o poeta, neste lapso agonístico, perder a referencialidade que a linguagem - duplo deste cosmo - até então the oferecera. 0 redescobrimento do espaço e do próprio tempo somente se dará através da reinvenção desta mesma linguagem. A propósito, cabe aqui dizer que, segundo Manuel Ulacia, é lícito supor que boa parte desta crise da noção de espaço, instantânea em Blanco, teve como intenção criar uma visão de universo que correspondia à cosmologia expressa por Severo Sarduy, poeta cubano e um dos nomes mais importantes da literatura hispanoamericana, que em Barroco afirma que

\footnotetext{
“la teoría relativista de la gravitación postula un universo que, en lugar de ser un objeto más o menos definido a priori, se transforma en una estructura espacio-temporal cuyas propiedades métricas no pueden conocerse exactamente si no se conocen las de la distribución de la materia que contiene. Es decir, se descubre una relación matemática y causal entre el "contenido" material y la "forma" espacio-temporal: el espacio no es independiente de los cuerpos que contiene - el verbo contener se convierte en una nación caduca las propiedades métricas del continente están asociadas a las del contenido; la relatividad generalizada excluye la idea clásica de un marco universal en cual se puede, teóricamente, incluir no importa qué conjunto de objetos, o no importa que secuencia de eventos ${ }^{590 \prime \prime}$.
}

588 PAZ, Octavio; CAMPOS; Haroldo. Transblanco. São Paulo: Siciliano, 1994. p. 69.
589 Ibidem.
590 SARDUY, Severo. Barroco. Buenos Aires: Sudamericana, 1974. p. 87 apud ULACIA, M. Ibidem. p. 309. 
De certa forma, Blanco também é um poema que visa estabelecer no espaço do papel uma visão poética do cosmo e das transformações que nossa visão acerca dele recebeu. Sobre esse diálogo com os saberes estabelecidos pela ciência, o poeta Gyorgy Somlyó diz, em O poeta do tempo capturado, que nesse tempo "plural"

\footnotetext{
"as concepções de tempo das diversas culturas, antes isoladas, confrontaramse, mesclaram-se e se enredaram mais ainda com as novas hipóteses das ciências naturais e sociais. [...] Tivemos que conceber o macro e o microcosmo e, entre eles, a história humana, vendo nisto tudo mediações verdadeiras da vida do homem que as atravessa e reconhece. Nada perturbou tanto as artes literárias em nossa época quanto estas mudanças que se introduziram no modo de conceber o tempo ${ }^{591 "}$.
}

Somlyó atesta que esta tensão entre as múltiplas temporalidades está presente na obra de Paz. Curiosamente, em poema dedicado ao poeta húngaro, Paz vislumbra este confronto entre infinito e calendário, origem e desdobramento, história e desenvolvimento técnico-científico, em Fábula del 28 de noviembro de 1968:

“Pero antes de cuál Era

En cuál Después del Hombre de Pekín

En cuál Antes de la XXVII Dinastía Robot-PMXO-9

Si el calendario ya no encierra

Tal una montura de diamante en una corona

Si aceleramos su poco de tiempo

Hasta volverlo tiempo desmedido [...]

Si lo dejamos caer de esa ficción humana

Aparato de la gravitación temporal

[...] Con el tic tac del reloj

Con esta mano

${ }^{591}$ SOMLYÓ, György. O poeta do tempo capturado. In MACIEL, Maria Esther (Org.) A palavra inquieta: homenagem a Octavio Paz. Belo Horizonte: Autêntica, 1999. p. 23. 
Sobre el papel hace un instante todavía blanco ${ }^{592 " .}$

Esta aleatoriedade do tempo é visível nas múltiplas possibilidades de leitura dos versos de Transblanco, perfomando sentidos diversos, através de um regime de simultaneidade, uma vez que estão entrelaçados espaço e tempo, emulando um tecido de signos. É por esta razão que o branco da própria página não é independente dos outros signos poéticos aqui presentes, mas lhe volve em relação.

A reinvenção da linguagem será tornar o corpo o duplo deste universo onde tempo e espaço dançam juntos. Este corpo reluzente, visível pelos instantes do amplexo, deposita sentido à temporalidade presente e imbrica, na própria estrutura do poema, a emulação do abraço, como sugerem os versos:

\author{
“minhas mãos de chuva escurecidas pelos pássaros \\ sobre teus peitos verdes suficiente beatitude \\ mulher estendida feita à imagem do mundo \\ O mundo feixe de tuas imagens ${ }^{593 "}$.
}

Para Maria Esther Maciel, as duas colunas, a da esquerda e a da direita, cada uma representada por uma cor, justamente, o vermelho e o preto, representam o movimento erótico de dois corpos. Em Lição do Fogo, ela diz que

\footnotetext{
"talvez o poema "Blanco", [...] fragmentado em vários poemas avulsos e dispostos de forma não linear sobre a página, oferece, através do jogo das colunas da direita e da esquerda - em seus movimentos de aproximação e distanciamento - uma simulação ritualizada do ato erótico. Nele, o que é dito se materializa no dizer, os temas do erotismo e da criação poética são encenados através de elementos sonoros e visuais da matéria verbal. O poema
}

\footnotetext{
592 PAZ, Octavio. György Somlyó. Fábula del 28 de noviembro de 1968. In Obras Completas. Vol. VII. Cuidad de Mexico: Fondo de Cultura Económica, 2014. p. 971.

593 PAZ, Octavio. Ibidem. p. 72.
} 
se constitui, assim, à feição do ritual erótico, como cerimônia de transfiguração".

Daí os versos sinestésicos envolvendo as cores outrora citadas, bem como as referências aos sons musicais, como em "tambores tambores tambores ${ }^{594 " . ~}$

A seguir, o poeta, num instante de iluminação e lucidez, percorre os cinco sentidos a girar em torno da mesma pedra, a ametista "ensimesmada", instante de "treslumbramento". A formação deste signo neologístico abarca o prefixo tres, cujo significado de origem aponta para "superação" ou um "movimento além de" do espanto momentâneo, causado pelo "alumbre", pela iluminação sucedânea e abundante. O treslumbramento, portanto, é a superação do estado em que quedamos imobilizados perante a luz. Ao contrário de Fausto, homem de especulação, o poeta não se cala diante da luz, pois abriu mão de seu próprio ego e decidiu falar:

“Não penso, vejo

- Não o que vejo,

Reflexos, pensamentos vejo.

A música, precipitações,

O número cristalizado.

Um arquipélago de signos.

Aerofania $595 "$.

Em suma, a correlação entre signos estrelares (cósmicos) e texto é chamado pelo poeta de aerofania, que aqui significa o ponto de convergência gravitacional do poema. Os signos rotacionam como as estrelas, mas seu polo central é a ausência de centro, por isso suas órbitas são livres, tal como a ordem de nossa leitura. Segundo Giraud, estes versos parecem aludir à "sílaba OM, sílaba sagrada por excelência do hinduísmo e do budismo Vajrayana, hierofania sonora, semente primitiva, ponto supremo [bindu] para

\footnotetext{
594 Ibidem. p. 70.

595 Ibidem. p. 74.
} 
o qual a consciência do iogui tende a dissolver-se e fundir-se ${ }^{596 "}$. Diante do esplendor do vazio, o poeta anula sua subjetividade e seu cantar resolve-se em mantra. Com isto, as condições de nossa experiência sensível, tempo e espaço, se desvanecem:

\author{
"Entre bosques impalpáveis, \\ As esculturas rápidas do vento, \\ Os sem-fins, \\ Desfiladeiros afiados, \\ Avanço, \\ Meus passos \\ Se dissolvem \\ Num espaço que se desvanece \\ Em pensamentos que não penso ${ }^{597 "}$.
}

Neste desvanecimento, a linguagem se torna silêncio, emulação da meditação, visto que cada verso-degrau acima representa um instante de respiração. A emulação do silêncio é a resposta do poeta para uma dificuldade dupla: como expressar o silêncio que é, por sua vez, expressão "imperfeita" do próprio Nada, acerca do qual nada podemos dizer? O que é o Nada? Paz diz em La llama doble que "es imposible que la nada sea algo, porque si fuese esto o aquello no sería, dejaría de ser nada. Pregunta insensata e cuya única respuesta es el silencio... que tampoco es una respuesta598". Por não ser uma resposta, o poema prossegue. Tudo em suspenso, o poeta despenca num estado de transe que será, novamente, erótico.

A imagem da Queda nos remete, novamente, ao mito adâmico. Ainda que esta queda seja uma queda erótica sobre o corpo do outro, no momento do enlace, como nos mostram os versos

\footnotetext{
596 GIRAUD, Paul Henri. Octavio Paz: caminho para a transparência. Trad. António Teixeira. Lisboa: Instituto Piaget, 2002. p. 365.

597 PAZ, Octavio. Ibidem. p. 75.

598 PAZ, Octavio. La Llama Doble. Barcelona: Seix Barral, 2001. p. 177.
} 
"cais do teu corpo a tua sombra não além mas em meus olhos

queda imóvel de cascata céu e solo se juntam

cais de tua sombra a teu nome horizonte intocável

$[\ldots]$

cais de teu nome a teu corpo o mais além da visada

num presente que não acaba o imaginário da areia

$[\ldots]$

hera arbórea língua tição de frescor o firmamento é macho e fêmea

$[\ldots]$

teu corpo são os corpos do instante é corpo o tempo o mundo

pensado sonhado encarnando-se visto tocado esvaído ${ }^{599}$

Ainda podemos inferir que estes versos nos apontam que cair no tempo, como caíram Adão e Eva, suscita uma única alternativa ao seu desdobramento implacável: o amor como a aposta. Se reinventar a linguagem é torna-la corpo, ao fazê-lo, reinventamos também o próprio amor. A Queda é a degradação ininterrupta do tempo original, primordial, a eternidade corrompida em sucessão. Para Paz, todos os pares revivem a esta queda na temporalidade que representa o mito de Adão e Eva, uma vez que, juntos, no amplexo erótico, tocam o Absoluto, mas após a cópula são expelidos novamente na aridez do vida, expulsos do jardim de Éden: "cada pareja sufre la nostalgia del paraíso, cada pareja tiene conciencia de la muerte y vive un continuo cuerpo a cuerpo... Reinventar el amor es reinventar a la pareja original, a los desterrados del Edén ${ }^{600 " .}$

Ao fim desta estrofe, a coluna central reaparece e apresenta a imagem do regresso ao copo como regresso à realidade:

\footnotetext{
"A irrealidade do visto

Dá vista à realidade ${ }^{601 "}$
}

\footnotetext{
599 PAZ, Octavio; CAMPOS; Haroldo. Transblanco. São Paulo: Siciliano, 1994. p. 76.

600 PAZ, Octavio. La Llama Doble. Barcelona: Seix Barral, 2001. p. 220.

601 PAZ, Octavio; CAMPOS; Haroldo. Transblanco. São Paulo: Siciliano, 1994. P. 77.
} 
O fantástico, o indizível, que nos "treslumbra", é o que dá sustentação a este mundo, é o que possibilita o Samsara, isto é, a realidade fenomênica a que costumamos chamar real. Porém, como a poética de Paz concilia os contrários, ocorre aqui o apagamento da distinção máxima do tantrismo budista, através da fórmula: Nirvana é Samsara, isto é, o irreal e o real se complementam (prajñaparatima), convergem, no interior de uma conjunção que abarca a existência num único instante, nesta centelha erótica que o poeta canta. $O$ ato de sua percepção não é distinto da concepção, do ato de criar e fabular. Novamente, perceber é conceber, como exposto em La llama doble:

\footnotetext{
“Las sensaciones son percepciones embrionarias, pues ¿̇entiríamos si no nos diésemos cuenta de que sentimos? A su vez, la percepción es concepción; al percibir la realidad le imponemos inmediatamente una forma a nuestra percepción, la construimos: "cada percepción es un acto de creación ${ }^{602 " . ~}$
}

A realidade não é apenas o que se fala e o que se diz, mas o que também escapa ao que o poeta busca expressar. Para Paz, o Ser é escorregadio, mal o digo, se esvai, pois como num caos original as semelhanças e diferenças se abolem constantemente, em um ir e vir perpétuo. Em El mono gramatico, encontramos um forte correlato destes versos de Transblanco:

"el árbol que digo no es el árbol que veo, árbol no dice árbol, el árbol está más allá de su nombre, realidad hojosa y leñosa: impenetrable, intocable, realidad más allá de los signos, inmersa en sí misma, plantada en su propia realidad: puedo tocarla pero no puedo decirla, puedo incendiarla pero si la digo la disipo.

el árbol que está allá entre los árboles no es el árbol que digo sino una realidad que está más allá de los nombres, más allá de la palabra realidad, es la realidad tal cual, la abolición de las diferencias y la abolición también de las semejanzas ${ }^{603 " .}$.

602 PAZ, Octavio. Op. Cit., 2001. p. 192.

${ }^{603}$ PAZ, Octavio. El mono gramatico. 3a ed. Barcelona: Seix Barral, 1990. p. 52. 
Liberto da dualidade, o poeta atinge a lucidez, uma vez que a outridade o liberta das identidades ensimesmadas e solipsistas que o prendiam à realidade desterrada.

Os últimos versos de Transblanco retomam a fonte e o espaçamento que abre este poema. Retorno cíclico? À medida em que a concatenação dos versos nos leva por este caminho, os espaços em branco oscilam os pares binários por excelência: Sim e Não. Ao mesmo tempo, o poeta começa a se acercar do mundo fenomênico, novamente, o instante poético aos poucos ressignifica o espaço como quem diz que o universo é aqui:

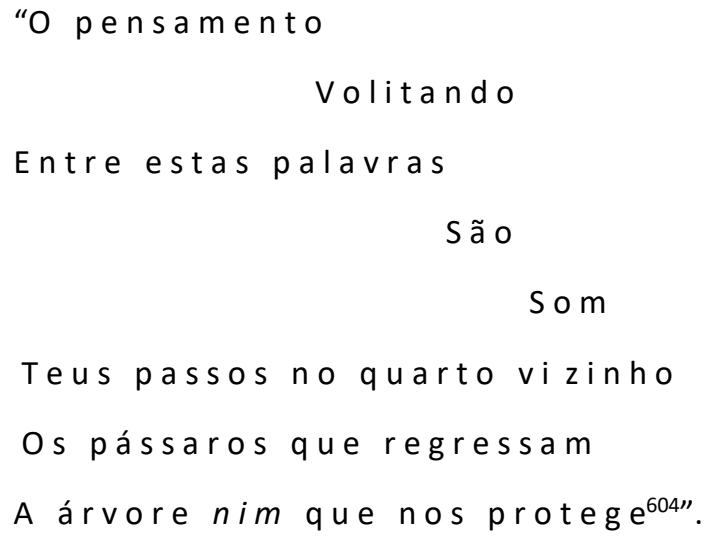

A imagem da árvore remete à árvore nim, conhecida como amargosa - árvore que perfilava no centro do jardim da casa de Octávio Paz na Índia, com quem morou junto de Marie José - remete o poeta à espacialidade reinventada. Porém, o que seus versos nos mostram, a partir da audição dos passos (da mulher?) no quarto ao lado, é que este instante erótico ocorreu no momento da escrita, uma vez que o texto se fez verbo e este se fez carne. A atração das colunas, a imaginação criadora, a sensibilidade perceptiva e a conjunção das faculdades do conhecimento concebeu um universo à parte. Tudo isto ocorreu enquanto o poeta estava com a pena na mão, ouvindo os pássaros, ouvindo a sua mulher passando ao largo da casa, num aqui e agora que foi celebrado nesta obra. Entre o Não e o Sim, o poeta repete os gestos de Mallarmé e lance os dados: "Se".

${ }^{604}$ PAZ, Octavio; CAMPOS; Haroldo. Transblanco. São Paulo: Siciliano, 1994. p. 79. 
Diante de um universo, onde a hiperinflação das imagens faz com que percamos a referência do que é a realidade, Octavio Paz, ao jogar com seu oposto, acaba por lhe conferir o sentido perdido:

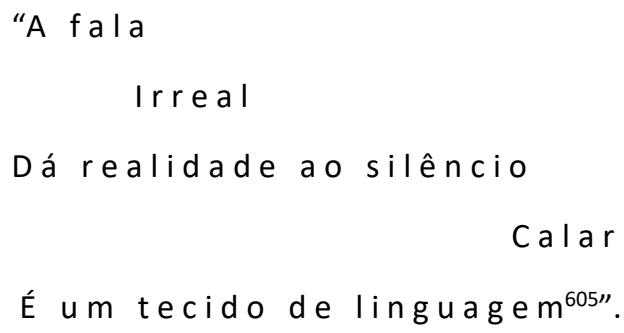

Sob este tecido, nos encontramos emaranhados num jogo de aparição e desaparição que constitui nossa porção de realidade. Ao fazer o corpo falar, através de seu texto, Paz ressuscita a realidade e, com ela, o espírito - enquanto invenção do corpo; o corpo enquanto invenção do mundo e; por fim, o mundo - enquanto uma invenção do espírito. Este triangulo espírito-corpo-mundo é a versão da estrela de três pontas da vacuidade. Aqui, a dupla chama se fez ato e consumou o pavio. O poeta, ao cabo de seu poema, em seu instante de situar-se, ainda revê as imagens que agora há pouco embaralhavam sua experiência. Novamente, ele retém os passos no quarto vazio e fixa a sua visão em seu texto que - tal qual o corpo - Ihe trouxe de volta a realidade plena de Ser:

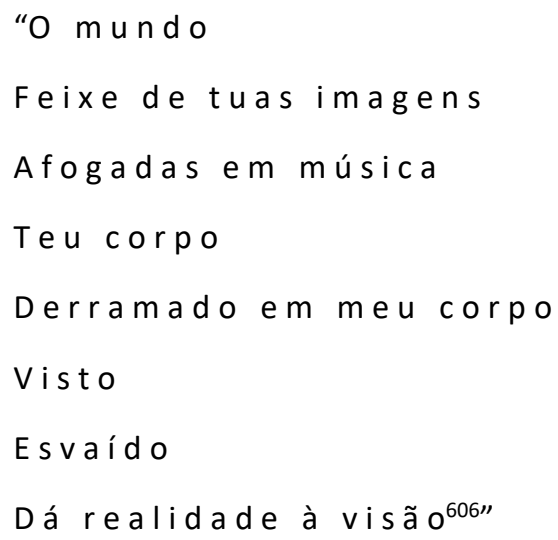

\footnotetext{
605 Ibidem. p. 81.
}

606 Ibidem. p. 83. 
Antes de finalizar estes versos, Paz repete que "a transparência é o que resta ao fim de tudo", verso já proferido anteriormente. Ao repetir tais instantes, o poeta utiliza um recurso anafórico que visa enlaçar momentos diferentes do mesmo texto. Para Giraud, “pode pensar-se que Blanco corresponde ao cume da obra poética de Octavio Paz e à realização de seu mito pessoal. Sexo, erotismo, amor, ascese, desprendimento, vacuidade, pensamento, corpo, paixão, passagem e palavra são alguns dos signos ${ }^{607 "}$ que, no interior do poema, operam a rotação em torno deste espaço a que Paz denomina branco,

\footnotetext{
"até criarem, no eu e tu poemáticos, mas também no leitor, o "pensamiento en blanco" que surge definitivamente como objeto comum do ritual tântrico e da experiência poética: o silêncio não é o fracasso da linguagem, mas sim a sua realização e o seu culminar608".
}

Anteriormente, este verso demarcava o instante de lucidez que sucedia o amplexo erótico, a situação em que as colunas emulavam o movimento erótico; agora, ao fim, num gesto mais reflexivo do autor que, acercando-se de sua atividade, de sua escrita, e rememorando no corpo textual o corpo vivo da mulher, transposta em sílabas poéticas, faz disto a oportunidade de estabelecer a correlação entre o instante amoroso e o instante poético, onde ambos nos levam à transparência e é ela, pois, o que sobra. 0 poema termina indicando que a reminiscência de uma imagem pode nos trazer de volta este instante sagrado. É chegado o momento em que a memória ressurge com seus fantasmas.

\footnotetext{
607 UD, Paul Henri. Octavio Paz: caminho para a transparência. Trad. António Teixeira. Lisboa: Instituto Piaget, 2002. p. 370.

608 Ibidem.
} 


\section{Noturno de San Ildefonso: reencontrar a memória, recriar a história}

A publicação de Nocturno de San Ildefonso (1976) ocorre vinte anos após a divulgação de Piedra de Sol (1956) e se distancia de Blanco em nove anos. Este arco nos possibilita ver como os três temas - mito, amor e história - se relacionam entre si. Este poema tem por objeto o Colégio de San Ildefonso, monumento histórico da capital, onde, segundo Horácio Costa,

\footnotetext{
"gerações e gerações de estudantes, entre elas a de Octavio Paz, passaram por essas arcadas e se prepararam para o ingresso na Universidade nesses pátios, convivendo com a plástica muralista, resultado da política cultural desenvolvida pela Revolução Mexicana ${ }^{609 \prime \prime}$.
}

Este espaço, já figurado em Pedra de Sol, retorna em Noturno de San Ildefonso sob a égide da imagem histórica e afetiva. Vejamos como ambas se entrelaçam e se organizam "ao redor de três níveis de memória [...], a individual, a coletiva e a urbanística610".

O poema é composto por versos livres, não-rimados - ainda que possamos observar uma cadência rítmica interna -, e dividido em quatro fragmentos. Nos primeiros versos de Noturno de San Ildefonso, temos a abertura com os seguintes versos:

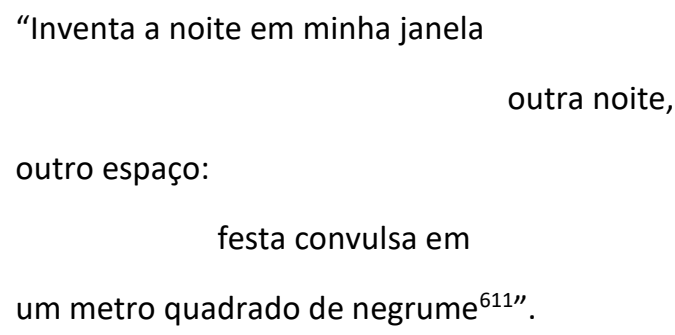

${ }^{609}$ COSTA, Horácio. Nota do Tradutor (2) In PAZ, Octavio. Noturno de San Ildefonso In O que nos faz pensar. Paixão Crítica: 100 anos de Octavio Paz. Rio de Janeiro: PUC-RJ, 2015. p. 182.

${ }^{610} \mathrm{Ibidem}$.

${ }^{611}$ PAZ, Octavio. Noturno de San Ildefonso. Trad. Horácio Costa In O que nos faz pensar. Paixão Crítica: 100 anos de Octavio Paz. Rio de Janeiro: PUC-RJ, 2015. p. 171. 
Octavio Paz inicia Noturno de San Ildefonso com duas imagens que serão centrais para a compreensão deste poema: a Noite e a Janela. Através da janela, em seu quarto se inventa a Noite. Cabe dizer que a imagem da noite é uma das imagens que, tradicionalmente, possui forte apelo romântico, a exemplo das Noites de Outubro de Gerard de Nerval, influência marcante neste poema, tal como em Pedra de Sol, que aqui operará como vaso comunicante. A figura da noite está associada a outras duas figuras que, como veremos, conferirão sentido às memórias afetivas e à Presença experienciada pelo poeta em seu caminho. Ainda que este poema vincule poesia e história, para seu tradutor Horácio Costa, não é a partir da narração histórica que ele recebe envergadura,

\footnotetext{
"ao contrário, é justamente contra a tela fosca de uma janela noturna, em cujo "metro de negrura" imprimem-se as luzes casuais e os reflexos de néon da cidade moderna, que Paz começa a ver fervilhar-se, em sua memória, o jovem de então e os cenários de sua formação intelectual e política ${ }^{612 " . ~}$
}

A imagem da Janela pode ser compreendida como um espaço de abertura ao mundo exterior e interior do poeta. Em seu mecanismo de abertura e fechamento, "lâmina imantada de chamadas e respostas" Paz deixa subsumido, implicitamente, a figura da guilhotina. A guilhotina, para além do nome do instrumento utilizado no terror revolucionário francês, é o nome dado à parte da janela que perfaz o movimento em que se queda a lâmina. Contudo, o que a janela de Paz corta não são cabeças, mas diálogos, através de seu mecanismo de chamada e resposta. Ao optar por mantê-la aberta, o poeta estabelece, no aqui e agora, um diálogo com seu passado juvenil, bem como às ideias e conviç̧ões juvenis que o habitaram na época que rememora. No mais, a imagem da janela também é uma imagem prenhe de significado filosófico, posto que ela também é o quadro que nos abre as vias da percepção. Tal como o quadro branco de John Locke, a janela figurou na filosofia moderna como o aparato pelo qual nossos sentidos recebem o fluxo sensorial presente no mundo - o que Bergson chamaria de "dado imediato". Para o filósofo Ettiénne Condillac,

${ }^{612}$ COSTA, Horácio. Nota do tradutor In Noturno de San Ildefonso. O que nos faz pensar. Paixão Crítica: 100 anos de Octavio Paz. Rio de Janeiro: PUC-RJ, 2015. P. 182. 


\begin{abstract}
"nossas experiências [...] se dão num instante: cabe ao entendimento destrincha-las posteriormente para apreendê-las. Nada mais cristalino que o exemplo da paisagem pela janela: se a abrirmos e fecharmos, imediatamente, não conseguiremos perceber nada do que vimos, e entretanto vimos, indubitavelmente, todos os elementos que a compunham ${ }^{613 "}$.
\end{abstract}

Porém, o golpe de vista de Paz neste poema é dado numa conjunção que mescla percepção e imaginação, sensação e memória. A abertura da janela não é apenas uma abertura dos sentidos ao mundo exterior, mas uma abertura do interior da memória ao instante perceptivo, enquanto seu complementar, conforme se verá em outras figuras da noite. Em outras palavras, para o crítico, o que vislumbramos neste poema de Paz é o receituário "clássico" da poesia moderna baudelairiana, a partir da experiência das flâneries. Nesta herança, “"'a deambulação imóvel” de Paz [...] vê o passado projetado na negrura da janela que observa, assemelha-se também ao resultado de uma disciplina ascética, na qual "o olho interior é quem vê", enquanto o corpo permanece estático ${ }^{614 " . ~}$ No mais, a abertura da janela operará no poema como uma exortação: assim como as mudas movem o aedo, através da janela, Paz percebe-se "tomado de uma sorte de "fogo sagrado"” onde identifica essa espécie de "poço do tempo" em suspensão ${ }^{615 " . ~}$

Os "signos-sementes", instantes capazes de germinar o tempo, são disparados pela noite, que os faz explodir no céu, nos remetendo à imagem dos fogos de artifício que estouram no céu para júbilo coletivo. Mas o fogo que faz arder o poeta é de outra natureza, é a chama da veia poética, pela qual o poeta se vê tomado pelo movimento imperioso da linguagem. No entanto, o signo dos fogos de artifício nos remetem ao instante da festa - instante que, como já o mostramos, nos remete à temporalidade original, similar à da poesia e do amor. Palavras-fogos-de-artifício, "racimos de sílabas", para, enfim, como na lógica da festa, converter-se, ao final, em "cacos outra vez ${ }^{616 " . ~}$

\footnotetext{
${ }^{613}$ SILVA, Lourenço Fernandes. O animal em Condillac ou as Reinvenções do Humano. Dissertação (Mestrado) São Paulo: Faculdade de Filosofia, Letras e Ciências Humanas. Depto. de Filosofia, 2015. p. 50. ${ }^{614}$ COSTA, Horácio. Ibidem. p. 184.

615 Ibidem. p. 182.

${ }^{616}$ PAZ, Octavio. Ibidem. p. 172.
} 
Ao manter sua mirada sobre a janela, o poeta sofre um deslocamento aos locais de sua memória, à medida em que estes espaços vão ganhando vivacidade em sua mente. Ainda no primeiro fragmento, temos, em continuação ao último verso citado:

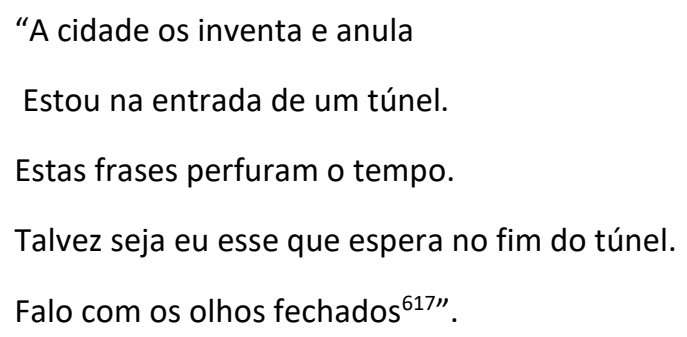

A persistência da memória é o que atravessa o ritmo caduco do tempo. Neste momento, o poeta fala consigo mesmo a um interlocutor que, aos poucos, traça-se como a si mesmo. Fala de olhos fechados, pois é através das imagens bruxuleantes da memória, contornadas pela noite que se faz perceber e que a linguagem poética vai constituindo seu itinerário.

O poeta é guiado pela Noite como que por uma tormenta (ou será uma tentação?):

\author{
“Alguém \\ plantou em minhas pálpebras \\ um bosque de agulhas magnéticas \\ alguém \\ guia a fileira destas palavras ${ }^{618 \prime \prime}$
}

Estas agulhas magnéticas são o que atraem as imagens à memória, movendo o fluir das palavras na página escrita. Quem é esse alguém que guia o poeta? Ora, trata-se da mesma pessoa que escreve o poema, porém imbuído do "fogo sagrado", isto é, da

617 Ibidem.

618 Ibidem. 
palpitação da outridade que, aos poucos viceja, mas ainda não vigora. A página torna-se um formigueiro, pois as palavras, em suas sílabas, vibram e movem-se freneticamente entre si, à medida em que as imagens, seu alimento, vão ressurgindo do subterrâneo. A seguir, retemos a imagem da Queda:

\section{“Caio}

Interminavelmente sobre esse vazio

Caio sem cair ${ }^{619 \prime \prime}$.

Como vimos em Transblanco, a Queda associa-se à solidão e aos seus labirintos. O poeta percebe-se só, acompanhado unicamente da linguagem. Apesar de suas mãos frias, seus pés frios, as palavras, o alfabeto, como em seu movimento formigante, "ardem, $\operatorname{ardem}^{620 "}$ no interior da noite. As palavras são como o sintoma de uma febre que acomete um corpo a se recuperar de sua condição enferma, a convalescer e a perceber, de forma paulatina, o ser redor com outros sabores e cores. Para Nietzsche, a convalescença é o estado através do qual atingimos outra vivacidade da realidade, uma vez que nossos humores reencontram, justamente, a saúde como a uma velha conhecida. Mas, no caso de Octavio Paz, a velha conhecida, que the traz estes novos estímulos sensoriais de uma maneira nova, através da memória, é a própria Noite. Personificada, tratando-o como um enfermo que ainda arde em febre:

"A noite insiste, a noite apalpa minha testa, apalpa meus pensamentos.

O que quer? ${ }^{621 "}$.

\footnotetext{
619 Ibidem.

620 Ibidem.

621 Ibidem.
} 
Com esta questão, em forma de espanto, Paz encerra o primeiro fragmento do poema. A noite vem para expurgar imagens, desvendá-las, habitá-las para, então, fazer o poeta despertar no sono - como último alento. Vejamos como isto se configura.

A partir do segundo fragmento, Paz começa por situar o registro histórico e o urbano invocados pela sua memória. Novamente, os signos associados à Noite perduram no interior do poema, como podemos perceber nos primeiros versos desta parte:

\author{
"Ruas vazias, luzes tortas. \\ Numa esquina, \\ o espectro de um cão. \\ Procura no lixo, \\ um osso fantasma ${ }^{622 "}$.
}

O osso fantasma prepara terreno para a entrada, no poema, de uma das principais figuras associadas pelo Romantismo à Noite. Como dirá Paz mais abaixo: "C'est la mort - ou la morte... ${ }^{623 "}$. Com a morte, retornarão imagens que estiveram associadas ao dia em outros poemas, numa transfiguração imagética que consolidará, a nosso ver, um reparo histórico em certa visão estereotipada da consciência coletiva bem como da identidade mexicana. Movimento semelhante ao realizado no Post-Scriptum de $O$ Labirinto da Solidão.

Antes de explicarmos este movimento, analisemos outros aspectos importantes deste segundo fragmento que nos farão compreender melhor essa "reparação" realizada pelo poema. Em primeiro lugar, Paz nos oferece uma data no verso "México, lá por 1931". Ainda que a expressão "lá por" identifique traços de imprecisão, ele nos indica um ponto memorial que operará aqui como referência primeira. Trata-se de seu ano de ingresso no Colégio de San Ildefonso e período que publicou o seu primeiro poema ou, como chama Horácio Costa, de sua plongée proustiana, pela qual, pode-se afirmar que "resolve-se mais em escuros do que em claros, a bem dizer contactando-se,

\footnotetext{
622 Ibidem. p. 173.

623 Ibidem.
} 
como se projetada no negrume da janela que tudo enquadra, com as luminescências noturnas visualizadas durante o momento da escritura624". Por isto, neste verso, observamos a persistência de signos que endossam o caráter noturno do poema, como se já indicassem que as questões pertinentes à mexicanidade, adiante enunciadas, devem resolver o que esta civilização possui e possuiu de trevas.

Novamente, o espaço recebe os contornos da palavra poética e vemos retornar os dois signos que moveram o primeiro poema aqui analisado: pedra e sol. Vejamos:

\author{
A esta hora \\ os muros vermelhos de San Ildefonso \\ são negros e respiram: \\ sol feito tempo, \\ tempo feito pedra, \\ pedra feita corpo ${ }^{625 "}$.
}

A correlação analógica sol-tempo-pedra-corpo aponta para a imagem arquetípica sobre a qual se ergueu o império asteca, cujos tijolos ergueram, por sua vez, o Vice-Reinado da Nova Espanha. O elemento que a todos perpassa poderia ser o sangue, como indicaremos a seguir. A partir deste segundo fragmento, podemos afirmar que Paz, ao situar o sol - assim como o dia - no passado, visa a, como primeiro ato de reparação de uma imagem dialética, dessacralizá-lo, despi-lo de sua carga histórica que o fez pedra e o fez corpo através do sangue imolado nos rituais de sacrifício. Evidenciar nesta imagem seu caráter mítico é desnudá-lo das forças opressivas que a subjugavam no interior de uma experiência política que suprimia a liberdade. Uma vez feito este movimento, o segundo ato será devolver a estas figuras, através de uma ação livre - isto é, a poiesis o caráter sagrado das mesmas, torna-las oníricas novamente, porém, numa ambiência que não os faça signos da mutilação e do assassínio. Vemos nos versos seguintes uma vaga lembrança do brilhar do sol na memória afetiva do poeta:

${ }^{624}$ COSTA, Horácio. Ibidem. p. 183.

625 PAZ, Octavio. Ibidem. p. 173. 
"Ao sol,

as casas eram de prata:

cidade de cal e cantaria,

lua caída ao lago ${ }^{626 ”}$.

Porém, logo a seguir, esta imagem - dócil - nos remete diretamente ao calendário asteca. Na sequência, Paz menciona implicitamente o ano de 1790 , em que foi desenterrado o guarda-sol asteca e depois dependurado na parte exterior da Catedral Metropolitana da Cidade do México, em uma de suas torres, até o ano de 1885:

“Os colonos levantaram, sobre o canal aterrado e o ídolo enterrado outra cidade

- não branca: rosa e ouro ideia tornada espaço, número tangível ${ }^{627 ” " . ~}$

A Pedra de Sol não era elemento de um ritual de Iluminação, no sentido que o compreende o poeta, mas uma das formas de fazer interromper a roda inefável do tempo e da mudança. Era a imposição de um arquétipo temporal que, para subsistir, custava aos povos dominados pelos astecas o seu sangue. Neste sentido, ainda que não esteja associada à Noite, a Pedra do Sol estabelece uma continuidade com esta imagem através do signo da Morte, uma vez que a "galeria de ecos", as "imagens quebradas" endossam as figuras iniciais dos ossos fantasmas. Esta imagem, reminiscência que atinge o âmago do poeta, é uma imagem coletiva: aqui, Paz pensa menos por si e mais pela coletividade mexicana. O poeta se faz outridade para com os outros lembrar junto "nossa história/. [A] Calada nação de pedras ${ }^{628 " . ~ O r a, ~ j a ́ ~ a f i r m a m o s ~ q u e ~ d i a n t e ~ d o ~ c a l a r-~}$ se dos filósofos analíticos defronte o Ser, o poeta opta por dizer o indizível: aqui ele

\footnotetext{
626 Ibidem.

627 Ibidem. p. 174.

628 Ibidem.
} 
destapa a boca da Nação e se põe a pensar, em sua particularidade molecular, seu passado histórico que retorna através da Janela, contra o "opróbrio do presente".

Adiante, contrastam-no figuras da juventude, que talvez perfilaram entre as que talvez tenham sido as primeiras figuras de referência literárias para o poeta: Aliosha Karamázov e Julien Sorel, de Os irmãos Karamázov de Dostoievsky e O vemelho e o Negro de Stendhal, figuras vulneráveis. Que se justapuseram como polos pelo meio do qual o poeta e seus amigos inventassem "destinos de relâmpago". Sucessões de erros? Adiante, uma nova imagem soma-se às demais: o vento, "do pensamento", "que brinca com espelhos", construtor das casas de ar" e que estabelece as

\title{
"geometrias
}

suspensas do fio da razão ${ }^{6291}$.

Ao brincar com espelhos, o vento, inevitavelmente determina o curso da atividade poética, coloca o poeta diante de si mesmo, fazendo-o ver - neste instante poético nesta mônada que conserva a totalidade do acontecimento de uma vida, seus distintos reflexos, suas distintas idades, seus "eus" fragmentários que voltam através dos passos cintilantes pela cidade noturna. Aos poucos, o poeta começa a expressar a dúvida sobre quem é, como em outro de seus poemas, O ramo e o vento, onde responde:

\author{
“Eu nada sou \\ corpo que flutua, luz, aragem; \\ tudo é do vento \\ e o vento é o ar sempre em viagem ${ }^{630 "}$.
}

Como o movimento do vaivém do vento, sempre dotado de um sentido que modula aspirais, convergindo no poema dos instantes que figuram como brisa aos impactantes

\footnotetext{
629 Ibidem. p. 175.

${ }^{630}$ PAZ, Octavio. O ramo e o vento. Trad. Horácio Costa. Belo Horizonte: Autêntica Editora, 2012. p. 23.
} 
ciclones, a palavra poética joga o poeta a seu bel-prazer. O vento do pensamento que sopra, infla a palavra, e a converte em chama. Assim, as palavras, como as ideias

“Ardem.

Arde, árvore de pólvora,

o diálogo adolescente,

súbita armação chamuscada.

12 vezes

dá murros o punho de bronze das torres ${ }^{631 "}$.

Novamente, a Noite presentifica-se através de suas imagens, agora a do sino. Este ponto referencial faz com que as imagens deste poema girem em torno desta Noite, pela qual toda tensão deverá passar: a memória, a poesia e a história. Ao escutarmos o poeta, em um arquivo de áudio, declamando o último fragmento de seu poema, escutamos ao fim os sinos da Catedral que ecoam o bronze sonoro ${ }^{632}$. A analogia entre os espaços da juventude - através das imagens urbanas que se apresentam pela memória - e a Noite, tornam este texto um duplo da História, assim como Transblanco se apresentou como duplo do corpo:

“Dispersamo-nos,

não lá na praça com os seus trens queimados,

aqui,

sobre esta página: letras petrificadas".

Aqui é o local por onde o poeta - imóvel - vê o desfile de espelhos que carregam a sua imagem e a imagem de seu povo. Os signos da noite o rememoram que a sua atividade, a escrita, se faz simultaneamente ao acontecer destes eventos que descreve com tanta

${ }^{631}$ PAZ, Octavio. Noturno de San Ildefonso. Trad. Horácio Costa In O que nos faz pensar. Paixão Crítica: 100 anos de Octavio Paz. Rio de Janeiro: PUC-RJ, 2015. p. 175.

632 É possível verificar a leitura de Paz no link: https://www.youtube.com/watch?v=6GIO3BTof38 (último acesso em 4 de julho de 2019). 
vivacidade. Trata-se, portanto, não de uma anulação do passado, mas de sua conversão em presente.

A partir do fragmento 3, temos o aprofundamento desta jornada de Paz em direção a si mesmo:

\author{
O jovem que caminha por este poema, \\ entre San Ildefonso e o Zócalo, \\ é o homem que o escreve: \\ esta página \\ também é uma caminhada noturna".
}

Mesmo na agrura da Noite, submetido ao temor, o poema se volve em caminhada, como El mono gramatico. A página converte-se, pela transfiguração poética, no locus pelo qual percorrerá este universo interior de suas memórias. Ao visualizar o baile de espelhos, o poeta se reconhece e, oscilando entre seu quarto - onde está imóvel mirando a janela - e o jovem que percorre o centro histórico da cidade, consegue ver um fio de identidade que podemos chamar de permanência ${ }^{633 "}$.

Como um gesto da maturidade que reconhece na juventude a chama da "boa intenção", no que, a nosso ver, configura o terceiro ato de reparação do poema, temos:

"O bem, quisemos o bem:

botar o mundo em ordem.

Não nos faltou inteireza:

Faltou-nos humildade ${ }^{634 \prime \prime}$.

633 O Pátio do Colégio de San Ildefonso, local por onde percorre o jovem poeta, reencontra nos dias de hoje o mesmo: guarda as cinzas de Octávio Paz desde 2018. Mais do que nunca, este local representa, hoje, um monumento à memória do poeta.

${ }^{634}$ Ibidem. p. 176. 
Neste mea culpa, o poeta fala de si ou fala de todos? O pronome utilizado não nos engana, Paz fala pelos mexicanos. Para Horácio Costa, neste trecho, nós podemos observar que "a memória individual dimensiona-se em coletiva; a autocrítica, em interpretação da história; neste sentido, este "Noturno" espelha as críticas que Paz enceta contra os extremismos políticos e ideológicos em sua ensaísta coeva ${ }^{635 " . ~ N e s t e ~}$ sentido, a autocrítica, longe de reduzir-se à penitência cristã, aparece como um signo de resistência à ideia moderna de História neste poema. Como já indicamos, ao desnudar o caráter de "mito" da História, assim como da própria crítica, Paz possibilita estabelecer uma ponte que reviva as imagens soterradas pelas narrativas hegemônicas. Para Celso Lafer,

\footnotetext{
"como diz Octavio Paz na Entrada Retrospectiva de El Peregrino en su Patria Historia y Política de México, este libro [...] dice respeto a las vicisitudes mentales e afectivas de la relación, no siempre feliz, de un escritor con su patria. São un diario de una peregrinación en busca de qué o de quién? En busca de México o de mí mismo? Talvez de un lugar en México: o del lugar en mí de México"? (El Peregrino en su Patria, Historia y Política de México, Obras Completas, vol. 8, México, Fondo de Cultura Económica, 1994, p. 16) ${ }^{6364 .}$
}

Ao contradizer a História - em seu sentido iluminista - neste trecho, Paz reafirma o movimento dialético da mesma, mesmo que não tenha intentado fazê-lo, mesmo que sua contraposição não seja a da imagem histórica, mas a da imagem poética - prenhe de memória histórica.

Ao assumir este ponto de vista autocrítico, Paz nos remete à sua crítica à Pirâmide no México, ao modelo que desde seu erguimento pelos astecas até os dias de hoje mantêm-se como uma estrutura de poder invisível, agora expressada pela burocracia. Ademais, Paz admite que a forma dogmática com que boa parte da

\footnotetext{
${ }^{635}$ COSTA, Horácio. Ibidem. p. 184.

${ }^{636}$ LAFER, Celso. Sobre Octavio Paz: vida e obra. In O que nos faz pensar. Paixão Crítica: 100 anos de Octavio Paz. Rio de Janeiro: PUC-RJ, 2015. p. 19.
} 
intelectualidade mexicana se aferra às doutrinas - sejam as revolucionárias ou não - é uma herança maldita da forma como se deu a colonização, embrenhada pelos preconceitos e pela "soberba de teólogos", onde o resultado não poderia ser senão a sucessão de sombras e imagens fantasmagóricas que acometem o poeta desde o início deste poema:

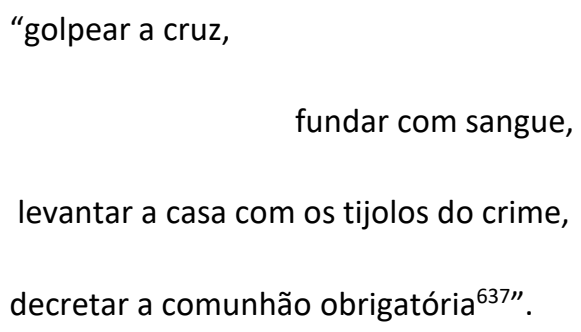

A seguir, o poeta expressa que estes mesmos teólogos se converteram em funcionários do partido. Boa parte destas críticas dirigem-se à esquerda latino-americana, de quem Paz se torna crítico à medida em que vai se desiludindo com o ideário socialista, graças aos eventos notórios dos processos de Moscou, do assassinato de Trotsky, etc. Assim, em regime de crítica dialética à História, Paz diz:

"A raiva

tornou-se filósofa,

sua baba cobriu todo o planeta.

A razão baixou à terra,

tomou a forma do patíbulo

- e a adoram milhões ${ }^{638 "}$

Essa ideia nos remete à ideia hegeliana de que a filosofia, quando vem do céu à terra como liberdade indeterminada - vem sempre sob a forma da destruição (e aqui a figura

${ }^{637}$ PAZ, Octavio. Ibidem. p. 176.

638 Ibidem. 
da guilhotina se mostra o reverso da Janela, outrora enunciada). Ora, mas a quem pertence a culpa por estes descaminhos?

Lembremo-nos da passagem de $O$ Labirinto da Solidão, onde o poeta diz que, aliado à falsificação histórica que corresponde ao Museu Nacional de Antropologia no México, o discurso hegemônico que elegeu os astecas - dentre zapotecas, tarascos e otomis - como os criadores do arquétipo originário do país expressa um sentimento de culpa que, por sua vez, se transforma na glorificação da vítima ${ }^{639}$. Para Paz, esta glorificação apenas corrobora para a perduração de uma visão nostálgica do último período asteca que mascara a forma de dominação vigente que, através das instituições modernas, foi atualizada como estrutura. Similarmente, no poema, veremos Paz classificar este sentimento de culpa transferida e projetada - através de nossos mecanismos de defesa do ego - como inocência, ou, como diz o verso: "a culpa que não se sabe culpa" e que foi incapaz de ver acumular o montante de ossos, tais quais o do massacre de Tatlelolco. Por conta disto, o poeta voltará a questionar sobre se sua própria história pessoal, enquanto mexicano que viveu as ideias universais como as suas, seria a história de um erro. Ao que se seguirá a resposta:

“A história é o erro.

A verdade é aquilo,

além das datas,

aquém dos nomes,

que a história desdenha:

o cada dia

- pulsação anônima de todos,

pulsação

única de cada quem -,

o irrepetível

cada dia idêntico a todos os dias ${ }^{640 "}$.

639 PAZ, Octavio. O Labirinto da Solidão. Trad. Ari Rotiman e Paulina Wacht. São Paulo: Cosac Naify, 2014. p. 278.

640 Ibidem. p. 177. 
Os ponteiros do relógio, assim como os dias da História, são caducos e, sem perceber, repetem-se a si mesmos, tal como Marx prenunciara na clássica passagem que abre o 18 de Brumário: primeiro como tragédia; depois como farsa. Nesta sequência ensimesmada, projetam-nos num futuro que jamais vigora, encarcerando o presente. Neste sentido, a história é um erro. Diante disso, a resposta de Paz é a mesma de seus outros poemas, porém cada vez recitada de uma forma nova e vívida, como vemos aqui:

é o fundo do tempo sem história.

O peso

do instante que não pesa: ${ }^{641 "}$.

O instante que como chama faz queimar uma imagem, a do sol, e lhe restitui novamente o sentido roubado durante séculos pelos "ladrões de vida" denunciados em Pedra de Sol. O instante poético, em sua natureza de radical alteridade restitui, repara as imagens e, com isto, devolve o sentido à própria história. O queimar do sol da poesia é um queimar sem lastro, sem sangue e que, ao fazê-lo, não se queima a si mesmo, pois se funda na liberdade da palavra. Este é o último ato de reparação histórica de Paz: retirar do mito o peso opressivo destas imagens para, assim, poder consagrá-las no instante poético, através do desvelamento operado pela poiesis.

Para Octavio Paz, o presente está sempre aqui, "oculto, imóvel, intocável", esperando o momento de abrir-se, desocultar-se, desvelar-se:

Entre o fazer e o ver,

ação ou contemplação,

escolhi o ato de palavras:

fazê-las, habitá-las,

dar olhos à linguagem ${ }^{642 "}$.

641 Ibidem.

${ }^{642}$ Ibidem. p. 178. 
Estes versos nos remetem os últimos versos de Transblanco, onde a irrealidade do visto dá realidade à visão. Ao escolher habitar a linguagem, Paz faz coro às palavras extraídas por Martin Heidegger de um poema tardio de Hölderlin, onde lemos que "para ouvir com inteireza as palavras "... poeticamente o homem habita...", é preciso devolvê-las cuidadosamente para o poema ${ }^{643 "}$. Quando afirmamos que Paz faz uma reparação das imagens mexicanas, com isto queremos dizer que ele as restitui poeticamente, ou seja, ele as reconstrói crítica e imaginativamente, tendo em vista que a habitação poética deve ser "entendida como deixar-se habitar, [pois] poesia é construir ${ }^{644 " . ~ A i n d a ~ q u e ~ a ~}$ poesia consagre uma data como Paz faz com o instante amoroso em Pedra de Sol, esta mesma data jamais se situará na esterilidade do tempo linear sucessivo, pois ela é presença e, enquanto tal, só pode existir enquanto este nosso modo de habitar e nós não habitamos senão no tempo. Mas, quem faz a história, diria Paz, são os homens e estes, por sua vez, na esteira do pensamento heideggeriano, são tempo: Dasein. A poesia, ao transfigurar as imagens, restituindo-lhes o seu Ser - para Paz, numa operação indistinta da ontológica - transfigura, também através do ritmo, os homens e a própria história, que se refaz a si mesma. Portanto, este poema que se assenta sobre a fonte da memória opera "uma ponte pênsil entre história e verdade ${ }^{645 ", ~ p o i s ~ t o r n a ~ a ~ p r i m e i r a ~ a ~}$ conjunção das imagens 'transfigurada na verdade do tempo não datado ${ }^{646 " . ~}$ Desentranhar o caráter temporal da história é restituir-lhe a verdade apagada, mas é, ao mesmo tempo, a revelação de que somos seres em suspensão - busca de solo, de um espaço, de uma referência para chamarmos real-, é também a busca do outro que nos devolve o firmamento: "fraternidade sobre o vazio".

No quarto e último fragmento os signos da noite voltam a se manifestar, mas o poeta já possui a consciência de que tudo está "por fim transfigurado/ na memória e em suas encarnações ${ }^{647 "}$. Como num sonho lúcido, o reminiscente colore o real com as suas cores. Na página que o poeta escreve, o seu texto segue sendo o duplo da história reescrita, reconfigurada. Porém, os signos exteriores revolvem a sua vista para lembra-

\footnotetext{
${ }^{643}$ HEIDEGGER, Martin. "... Poeticamente o homem habita..." In Ensaios e Conferências. Trad. Marcia de Sá Cavalcante Schuback. Petrópolis: Vozes, 2008. p. 165.

644 Ibidem. p. 167.

${ }^{645}$ PAZ, Octavio. Ibidem. p. 178.

${ }^{646} \mathrm{Ibidem}$.

${ }^{647}$ Ibidem. p. 179.
} 
lo de que a poesia é um construir constante, ela não cessa enquanto não cessar o poema:

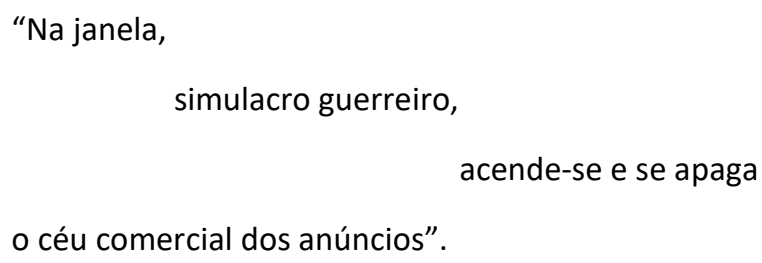

As lembranças da juventude de Paz dividem espaço com as imagens da sociedade de consumo que, paulatinamente, foi se instaurando na capital mexicana, brigando pela eloquência dos espaços históricos e apelando para a visualidade iluminada do néon. Mesmo a percepção da Lua está embotada e apenas subsiste como um produto construído poeticamente pelo imaginário. Estes instantes são o vigorar da ironia, a consciência que ainda vivemos um período que Paz não ousa dizer que o superamos, apesar de estar se esgotando: a modernidade. Os signos urbanos modernos embotam a sensibilidade que busca, como numa mirada nostálgica, a antiga arquitetura que compunha a paisagem da janela noturna, mesclada à vida natural das árvores.

Por fim, tendo cumprido o seu itinerário pela cidade, mas ao ter a sua visão obnubilada pela malha urbana - cada vez mais invasiva com seus outdoors e seu show de luzes - o poeta recebe da Noite a segunda imagem a ela tradicionalmente associada: a Mulher que "entre as penhas e as penas dos sonhos ${ }^{648 "}$ adormece sobre os travesseiros. Este instante se contrapõe à ansiedade que percorrera seu corpo, à ânsia febril movida pela tensão constante entre o dizível e o indizível. Ao ver sua amante, o poeta repousa os olhos para dentro do quarto sem, contudo, se esquecer do que passou. Quando ela começa a crescer em sua visão, o poeta reencontra a natureza que outrora buscara, através do mar e suas encostas. Como um aventureiro, pela visão ele explora seu relevo e vislumbra a vegetação e a água que "flui pelo seu talhe ${ }^{649 "}$ : a amante é o duplo do cosmos e, neste instante, volta a ser texto, como em Transblanco. Pacificamente, o poeta ainda se questiona, movido por um deslocamento de atenção

\footnotetext{
648 Ibidem.

649 Ibidem. p. 180.
} 
que é coerente à ressureição das imagens que presenciara límpidas à sua frente: e a sua mulher, o que será que sonha? De onde temos os versos:

\author{
“A verdade \\ é a marejada de uma respiração \\ e as visões que vêm uns olhos fechados: \\ palpável mistério da pessoa ${ }^{650 \prime \prime}$.
}

Novamente, nos aparece a imagem da oleaje, agora traduzida por Horácio Costa por "marejada", talvez por resguardar a associação semântica que "marulho" compartilha com barulho, contrários à "respiração" de quem dorme um sono tranquilo. O sentido da respiração, para Paz, não consiste apenas num procedimento mecânico, uma vez que, para o próprio poeta, o respirar, como o vaivém da oleaje é movimento erótico e vital. Por isso, esta imagem não ressurge gratuitamente após toda uma descrição erótica da amante que flui na cama, como sua respiração faz fluir, para o poeta, o próprio Ser encapsulado em sua mirada e sua pena.

Aos poucos, a aurora desponta no céu e o poeta defronta-se, pela última vez, com a Noite, através da morte:

“morrer

será cair ou subir,

uma sensação ou uma cessação ${ }^{651}$ ?"

Ao recuperar uma das questões que talvez mais façam jus à racionalidade ocidental, visto que evocam Sócrates no Críton, neste momento, perguntamo-nos: se Octavio Paz tivesse a consciência de que hoje este espaço histórico do Colégio de San Ildefosno guarda as suas cinzas, o que teria aqui escrito? Finalmente, como o último ato da noite, pensando que, talvez, a resposta de Sócrates que afirma que a morte talvez seja ela

650 Ibidem.

651 Ibidem. 
como um sono tranquilo, onde nada sentimos - um sonho que Paz chamaria blanco - o poeta olha para a sua mulher e decide a ela se juntar nos braços de Morfeu:

“Mulher:

fonte da noite

Eu me fio ao seu fluir sossegado ${ }^{652 "}$.

Finalmente, podemos afirmar que, defronte aos signos modernos e às luzes que invadem os apartamentos, o ato do sono, como o reservatório de nossas imagens poéticas, pode ser compreendido como uma ação resistente à imperiosa marcha do progresso que não cessa. Como já dissemos, a atividade do poeta só cessa quando a poema acaba, mas a cada nascer do sol, há um nascer do homem diferente e que nos põe, no tempo, a questão: como queremos habitar o mundo?

652 Ibidem. 


\section{Considerações finais}

Em uma entrevista concedida a Guillermo Sheridan, publicada em outubro de 1997, um ano antes da morte do poeta, Octavio Paz afirmou: "Nuestro interlocutor es el tiempo y cada línea que escribimos es una línea con, sobre, contra, hacia, por el tiempo ${ }^{653 \prime}$. Acreditamos que não há afirmação mais reveladora do que estas palavras proferidas pelo poeta nesta entrevista. Todo o nosso itinerário, que nos levou a fazer este recorte diante do eruditismo diverso e da vasta bibliografia de Octavio Paz, indicou que o tempo - enquanto questão proposta - perpassa, ainda que implicitamente, a todas as obras. Seja no trabalho biográfico que Octavio Paz realiza, demonstrando um olhar sincrônico da história capaz de trazer para o presente as vozes dissonantes outrora apagadas pela censura, pela opressão e pelo machismo, como é o caso de Sor Juana Inés de la Cruz; seja na sua experiência de imersão nas culturas orientais, de onde retira do tantrismo valiosas imagens, traduzíveis em termos poéticos em poemas como Transblanco, em que tocamos a vacuidade assim como o Absoluto, nesta obra que é duplo do corpo e duplo do cosmos; seja na sua postura contemporânea, segundo a concepção de Agamben sobre o termo, onde

\footnotetext{
“a contemporaneidade [...] é uma singular relação com o próprio tempo, que adere a este e, ao mesmo tempo, dele toma distâncias; mais precisamente, essa é a relação com o tempo que a este adere através de uma dissociação e um anacronismo. Aqueles que coincidem muito plenamente com a época, que em todos os aspectos a esta aderem perfeitamente, não são contemporâneos porque, exatamente por isso, não conseguem vê-la, não podem manter fixo o olhar sobre ela ${ }^{654 "}$.
}

O que a citação de Agamben nos explica aqui é, basicamente, a postura do poeta que evoca a "paixão crítica": crítica de si e de seus poderosos mecanismos de desconstrução. Ao tomar como suas as questões mexicanas, Paz assume seu posto de intelectual

\footnotetext{
653 PAZ, Octavio. Una apuesta vital. (Entrevista con Guillermo Sheridan). Vuelta, no 251. Octubre. México, 1997. p. 7

${ }^{654}$ AGAMBEN, Giorgio. O que é o contemporâneo? e outros ensaios. Trad. Vinícius Nicastro Honesko. Chapecó: Argos, 2009. p. 59.
} 
contemporâneo, mas, ao mesmo tempo se distancia - graças, em parte, ao seu cosmopolitismo; graças, sobretudo, à sua capacidade de estabelecer recortes sincrônicos no tempo, possibilitando-lhe vislumbrar o desenvolvimento de ideias e sentimentos na torrente fluída da história, como o amor em La llama doble, sem, necessariamente ter de assumir uma corrente de pensamento dogmática para explicar o tema tratado, mantendo a originalidade e a independência intelectual.

No interior desta habilidade em destrinchar a história, o encontro com o instante, este outro tempo, sobre o qual repousa toda a aposta vital da poesia de Octavio Paz, como este mesmo diz na entrevista supracitada, em que conseguimos observar que

\footnotetext{
“[El poema] también es ceremonia: un acto que nos arranca de la realidad inmediata y nos somete, nos sumerge, mejor dijo, en otro tiempo. Y puesto que he mencionado la palabra tiempo, y la palabra tiempo es fundamental en mi pensamiento, quiero decirle, una vez más, que para mí la poesía no es sino tiempo, y que, siendo tiempo, es muchas cosas: es rito, es ceremonia, pero es, sobretodo apuesta. [...] Apuesta vita ${ }^{655}$ ".
}

Aposta que se assemelha, por um lado, ao salto mortal à outra margem, à vacuidade que toca o Absoluto, no rompimento das contradições, e se impõe - de forma sublime - ao poeta, que desafia o real ao dizer; e, por outro, ao lance de dados mallarmaico, que faz da linguagem uma constelação de signos, a perfazer, no texto, o duplo de cosmo cuja imagem ainda não conhecemos, mas que Paz crê ser a estrela do agora, como aponta em La otra voz ${ }^{656}$. Aposta que figura no instante o seu caráter de liberdade.

No mesmo texto em que diz isto, intitulado Ruptura y Convergencia, escrito em 1986, Octavio Paz afirma que "el instante es el tiempo del placer pero también es el tiempo de la muerte, el tiempo de los sentidos y el de la revelación del más allá657”. Nesta mesma comunicação, em tom manifesto, defende que a poesia do agora - este "ahora encarnado sin fechas" - deve ser uma poesia de convergência, uma poesia em

\footnotetext{
655 PAZ, Octavio. Ibidem. p. 9.

656 PAZ, Octavio. Op. Cit. 2003. p. 517.

657 Ibidem. p. 516.
} 
que o ponto da mudança se confunda com o da permanência. Esta postura deve convergir consciência crítica e pensamento analógico: o poeta deve ser capaz de atar e desatar nós, deve ser capaz de sobrevoar a região e aterrissar o seu pouso no instante em que enxerga a possibilidade de vicejar a experiência da vivacidade. A arte, portanto, deve seguir como um aporte de resistência não apenas aos insumos do mercado, que a despovoam - pois "no hay veneno peor que el dinero ${ }^{658 " ~-, ~ m a s ~ t a m b e ́ m ~ a o ~ a l i c i a m e n t o ~}$ do Estado, que converte artistas em propagandistas. Eis, aliás, o que o mercado e o Estado possuem em comum. Em ambos, a arte pode se converter em mera publicidade.

Para Paz, então, trata-se de manter a potência do signo "Não". A manutenção do caráter negativo da obra, respaldado pelo seu sentido crítico, é uma demanda que se faz urgente: "Es indubitable que algo le falta a la literatura contemporánea. Ese algo es la silaba $N o$, una sílaba que ha sido siempre el anuncio de grandes afirmaciones ${ }^{659 \prime \prime}$. A defesa do agora e a demanda pela negatividade requerem certas posturas, muitas vezes, céticas. Porém, céticas em relação aos postulados que conferem ao futuro o sentido da tríade temporal, desertificando o presente. De onde decorre que Paz defende que "a primeira regra de uma educação realmente livre seria a de inspirar à infância a repugnância por todas as doutrinas de "felicidade obrigatória660"”. Em suma, nada que diga respeito à felicidade humana deve ser adiável, nada deve ser posto fora do agora.

A defesa do agora também é uma defesa do corpo e da sua presença no interior da obra de arte e da poesia. Como afirmamos, não o corpo-simulacro - publicidade das redes sociais e das revistas de moda -, mas o corpo do outro em sua radical heterogeneidade e imperfeição. A lição de Baudelaire foi tornar o poeta um trapeiro, aquele que recolhe na insignificância do material transitório sua porção de eternidade. Por que o haveria de ser diferente em relação ao outro? O que se torna um desafio num horizonte onde a superabundância de imagens empobrece o sentido do real, empobrece a materialidade do que é o corpo, uma vez que proliferam imagens plásticas e pornográficas que, em sua hiper-realidade, empobrecem a sensibilidade por torná-la viciada: o oposto do erotismo. Nesse sentido, a poesia pode oferecer dois caminhos para

\footnotetext{
658 Ibidem. p. 570.

659 Ibidem. p. 571.

660 PAZ, Octavio. Conjunções e Disjunções. Trad. Lucia Teixeira Wisnik. São Paulo: Perspectiva, 1979. p. 119.
} 
ressignificar o corpo: o primeiro, é o da festa, onde vivenciamos uma arte de participação coletiva em comunhão, onde a palavra poética se faz ato e gesto, onde os contrários se entrelaçam para anular-se depois, no dia seguinte; e o segundo, através de um diálogo silencioso com o universo e conosco, como sugere a experiência de Noturno de San Ildefonso, onde o poeta termina na quietude do silêncio, após um longo diálogo solitário com a Noite, em que esta se revelou como a Morte. Seja na solidão ou na comunhão, a poesia pode reencontrar o caminho em sentido ao corpo, ao outro.

Desta forma, mesmo a experiência do sono se faz uma tarefa necessária em nossos tempos, como sugerimos ao final da análise deste último poema, na esteira da crítica de Jonathan Crary, pois dormir e sonhar é, em suma, reafirmar o signo 'Não'. Em Agonia do Eros, Byung-Chul Han afirma que

\footnotetext{
“diante da enorme quantidade de imagens hipervisíveis, hoje já não é possível fechar os olhos. Também a mudança veloz das imagens não nos concede mais tempo para isso. Fechar os olhos é uma negatividade que não se coaduna bem com a positividade e hiperatividade da sociedade acelerada de hoje. A coerção para a hipervigilância, hoje, impede que fechemos os olhos ${ }^{661 "}$.
}

Por isso, a imagem imóvel da janela, a imagem noturna, aquela que conserva - caso contrário não existe - o enigma de ser real ou não (em contraposição ao hiper-real) é a imagem poética capaz de consagrar o instante. Assim o é também o universo onírico, onde, livre das fantasmagorias da vigília, se pode enfim sonhar. Diante da imagem plasmada e chapada dos smarthphones, a janela oferece um olhar que desafia nossa mirada, pois se oferece invés de se impor, convida o mergulho do ohar invés de clamar atenção na superfície táctil, tecnológica e pixelizada do reclame.

Talvez, por conta disto, a questão que urge hoje é: onde está o Outro? Como encontra-lo? A necessidade da questão demonstra que sua resposta não é fácil, visto que, para Han, se pensarmos em uma das experiências que mais nos conecta ao outro,

${ }^{661}$ HAN, Byung-Chul. A Agonia do Eros. Trad. Enio Paulo Giachini. Petrópolis: Vozes, 2017. p. 73. 
o amor, é compreendida como crítica, hoje, e quiçá viva um de seus piores momentos. A razão disto, para Byung-Chul, não é, como erroneamente se poderia apontar,

"a oferta de outros outros que contribui para a crise do amor, mas a erosão do Outro, que por ora ocorre em todos os âmbitos da vida e caminha cada vez mais de mãos dadas com a narcisificação do si-mesmo ${ }^{662 " .}$.

Consoante a este diagnóstico, Octavio Paz se questiona: "Ante esa realidade, ¿cuál puede ser la función de la poesía? ¿Qué puede decir la otra voz?”. A outra voz seria, precisamente, aquilo que poderia nos resgatar o outro - agora perdido em labirintos narcísicos de si mesmo. A nosso ver, a experiência poética é um dos pontos em que este tipo de experiência subsiste. Seu grande trunfo é a capacidade da linguagem de estabelecer conexão entre um e outro. Se a poesia conecta signos díspares, como isto e aquilo, penas e pedras, seu maior desafio hoje é, portanto, reunir o eu e tu: restabelecer a comunhão, a cisão que nos enclausura cada vez mais em nós mesmos (e em nossos trabalhos).

No mais, ainda que o horizonte seja desalentador, o poeta realiza a sua aposta, ciente do risco: "puedo decir con un poco de seguridad que, mientras haya hombres, habrá poesía. Pero la relación puede romperse. Nació de la facultad humana por excelencia, la imaginación; puede quebrarse si la imaginación muere o se corrompe ${ }^{663 "}$. Uma vez que o poeta admite a possibilidade de a imaginação se corromper ou, o que é mais provável, se empobrecer diante da hipertrofia de imagens, a poesia deve se manter no propósito de ser busca: busca do outro e busca do presente. Busca da morada e busca do enigma, onde, para encontra-lo, se deve preservar o enigma, pois não há desvelamento sem velamento, não iluminação sem trevas, não há um sem o outro. 0 binarismo das relações só possui sentido, em Paz, quando a poesia os rompe e os fragiliza em intercâmbios que emulam o jogo erótico dos casais. Esta busca requer a lucidez de se saber que todos os tempos convergem no presente e o fazem a partir de

\footnotetext{
662 Ibidem. p. 7.

${ }^{663}$ PAZ, Octavio. Ibidem. p. 592.
} 
duas características essenciais: a simultaneidade e a pluralidade. Octavio Paz assume que o mundo é global e comunicante, todos as temporalidades nos habitam. A pluralidade possui a forma do caracol, como expõe em El mono gramatico:

\footnotetext{
"Como en el caracol marino, todos los tiempos son este tiempo de ahora que no es nada salvo, como el cuarzo de cristal de roca, la condensación instantánea de los otros tiempos en una claridad insustancial ${ }^{664 " . ~}$
}

Em seu discurso a propósito do recebimento do prêmio Nobel em 1990, cujo título é, justamente, A Busca do Presente, o poeta, no entanto, relembra esta temporalidade outra, a dos amantes, a da festa e a da revolta: o instante. Como apreendê-lo? Como não tornar este tipo de presença um registro de antigas civilizações, pré-industriais, précibernéticas? Como continuar a habitar poeticamente em um mundo cada vez menos lúdico, em que a luz da razão mais nos cega que esclarece? É preciso ter memória. Por isto, ele diz:

\footnotetext{
“Em minha peregrinação em busca da modernidade me perdi e me encontrei muitas vezes. Voltei à minha origem e descobri que a modernidade não está fora, e sim dentro de nós. É hoje e é a antiguidade mais antiga, é amanhã e é o começo do mundo, tem mil anos e acaba de nascer. [...] Simultaneidade de tempos e de presenças: a modernidade rompe com o passado imediato para logo resgatar o passado milenar e converter uma figurinha de fertilidade do Neolítico em nossa contemporânea. Perseguimos a modernidade em suas incessantes metamorfoses e nunca conseguimos pegá-la. Escapa sempre: cada encontro é uma fuga. Abraçamo-la e logo ela se dissipa: era só um pouco de $\operatorname{ar}^{6651}$.
}

${ }^{664}$ PAZ, Octavio. El mono gramatico. 3a ed. Barcelona: Seix Barral, 1990. p. 133.

${ }^{665}$ PAZ, Octavio. A busca do presente. Trad. Eduardo Jardim. Rio de Janeiro: Bazar do Tempo, 2017. p.

92. 
Seguimos sendo modernos, em busca da mudança como o fundamento da existência e do tempo. Contudo, para Paz talvez o momento da convergência dos tempos concilie essa nossa ânsia por projetar-se no tempo ao nos oferecer um presente pleno: manancial de presenças. Qual é, portanto, a natureza do instante? É a mesma do Snark, do pássaro fugidio, "que está em todas as partes e em nenhuma666", pois escorrega de nossas mãos e volve-se em palavras, sílabas, letras. Porém, quando menos o esperamos, o instante revela a presença do mundo, a real presença do outro, e tudo se concilia novamente, e "as veias deste infinito lhe parecem chegar ao coração ${ }^{667 " . ~}$

666 Ibidem.

${ }^{667}$ RAYMOND, Marcel. De Baudelaire ao Surrealismo. Trad. Fúlvia M. L. Moretto; Guacira Marcondes Machado. São Paulo: Edusp, 1997. p. 13. 


\section{Referências Bibliográficas:}

ADORNO, Thedor. O ensaio como forma. Trad. Jorge de Almeida. In Notas de literatura I. São Paulo: Ed. 34. 2012.

; HORKHEIMER, M. A dialética do esclarecimento. Trad. Guido Antonio de Almeida. Rio de Janeiro. Zahar. 2006.

AGAMBEN, Giorgio. O que é o contemporâneo?. Trad. Vinícius Nicastro Honesko. Chapecó: Argos, 2009.

Infância e História: Destruição da experiência e origem da história.

Trad. Henrique Burigo. Belo Horizonte. Ed. UFMG/Humanitas. 2012.

AGOSTINHO, Santo. As confissões. Trad. Frederico Ozanam Pessoa de Barros. São Paulo: Edameris, 1964.

ALIGHIERI, Dante. A divina comédia. Trad. Italo Eugênio Mauro. São Paulo: Editora 34. 2007.

ANDRADE, Carlos Drummond. João Brandão adere ao punk. Rio de Janeiro: Jornal do Brasil, 1983

BARTHES, Roland. A morte do autor. In O Rumor da Língua. Lisboa: Edições 70, 1970. - Mitologias. Trad. Rita Buongermino, Pedro de Souza e Rejane Janowitzer. Rio de Janeiro: DIFEL, 2006.

. Fragmentos de um discurso amoroso. Trad. Hortênsia dos Santos. São

Paulo: Editora Unesp, 2018.

BAUDELAIRE, Charles. O pintor da vida moderna. Trad. Tadeu Tomaz. Belo Horizonte: Autêntica Editora, 2010.

BENJAMIN, Walter. O Anjo da História. Trad. João Barrento. Belo Horizonte, Autêntica Editora. 2013.

O capitalismo como religião. Trad. Nélio Schneider. São Paulo: Boitempo editorial. 2012.

Passagens. Org e trad. Willi Bolle. São Paulo. Imprensa Oficial/ Ed.

UFMG. 2009.

Sobre alguns temas em Baudelaire In Charles Baudelaire, um lírico no auge do capitalismo. Trad. José Carlos Martins Barbosa e Hemerson Alves Batista. São Paulo. Brasiliense. 1994.

BERARDI, Franco. Depois do futuro. Trad. Regina Silva. São Paulo: Ubu Editora, 2019.

BERGSON, Henri. A Evolução Criadora. Trad. Pedro Elói Duarte. Lisboa: Edições 70, 2001. 
. A Intuição filosófica. Trad. Maria do Céu Patrão Neves. Edições Colibri.

Lisboa. 1994.

. Essai sur les données immédiates de la conscience. Gèneve: Édition Albert Skira, 1945.

- Matéria e Memória: ensaio sobre a relação do corpo com o espírito.

Trad. Paulo Neves. São Paulo: Martins Fontes, 1999.

BOLLE, Willie. Fisionomia da metrópole moderna. São Paulo: Edusp. 2000.

BOLZ, Nobert. "É preciso teologia para pensar o fim da história?” In Revista USP, nำ15, Dossiê Walter Benjamin. São Paulo. 1992

BORGES, Jorge Luis. Nova antologia pessoal. Trad. Davi Arrigucci Jr, Heloisa Jahn, Josely Vianna Baptista. São Paulo: Companhia das Letras, 2013.

BRAGA, Ruy. A rebeldia do precariado: trabalho e neoliberalismo no Sul global. São Paulo: Boitempo Editorial, 2017

BONFIGLIOLI, Cristina Pontes. O dar a ver de um buraco negro In Zum: revista de fotografia. São Paulo: Instituto Moreira Salles, 10 semestre 2019. Disponível em: https://revistazum.com.br/radar/buraco-negro (Acesso em 2 de junho de 2019).

BOSI, Alfredo. O Ser e o Tempo da Poesia. São Paulo: Companhia das Letras, 2000.

BRETAS, Alexia. A constelação do sonho em Walter Benjamin. São Paulo. Humanitas. 2008.

BRETON, André. L'Amour Fou. Saint-Amand: Éditions Gallimard, 2014.

CAMPOS, Haroldo. Constelação para Octavio Paz In PAZ, Octavio. Os Signos em Rotação. Trad. Sebastião Uchoa Leite. São Paulo: Perspectiva, 2009.

Poesia e modernidade: da morte da arte à constelação. O poema pós utópico. In O arco íris branco. São Paulo. Imago. 1997.

COSTA, Horácio. Octavio Paz, biógrafo. São Paulo: Revistas USP Março/Abril e Maio, 1990

. O traduzir como necessidade e como projeto In MACIEL, Maria Esther (Org.) A palavra inquieta: homenagem a Octavio Paz. Belo Horizonte: Autêntica, 1999.

Piedra de Sol: el título in Mar Abierto: ensayos sobre literatura brasileña, portuguesa e hispanoamericana. Ciudad de México: Fondo de cultura económica, 2000.

São Paulo. 1991.

. "Poíesis" e política: o modelo intelectual de Octavio Paz. Revista USP:

CRARY, Jonathan. 24/7: capitalismo e fins do sono. Trad. Joaquim Toledo Jr. São Paulo: Ubu editora, 2016. 
DERRIDA, Jacques. A escritura e a diferença. Trad. Maria Beatriz Marques Nizza da Silva, Pedro Leite Lopes e Pérola de Carvalho. São Paulo: Perspectiva. 2011

FABBRINI, Ricardo Nascimento. "O que está acontecendo com as imagens?", Campinas: Revista Filosofia e Educação. Vol. 8. №1. 2016.

FOUCAULT, Michel. O corpo utópico, As heterotopias. Trad. Salma Tannus Muchail. São Paulo: N-1 Edições, 2013.

FOSTER, HAL. The return of the real: the avant-gard at the end of the century. Massachusetts: The MIT press. 1996

GAGNEBIN, Jeanne Marie. História e narração em Walter Benjamin. São Paulo: Perspectiva, 2013.

GAOS, José. Introducción a El Ser y el Tiempo de Martin Heidegger. 2ª ed. México: Fondo de Cultura Económica, 2017.

GARCIA MARQUEZ, Gabriel. Cem anos de Solidão. Trad. Eric Nepomuceno. São Paulo: Record, 2014.

GIRAUD, Paul Henri. Octavio Paz: caminho para a transparência. Trad. António Teixeira. Lisboa: Instituto Piaget, 2002.

HAN, Byung-Chul. A Agonia do Eros. Trad. Enio Paulo Giachini. Petrópolis: Vozes, 2017. . Sociedade do cansaço. Trad. Enio Paulo Giachini. 2a ed - Petrópolis,

RJ: Vozes, 2017.

HEIDEGGER, Martin. A Origem da Obra de Arte. Trad. Idalina Azevedo e Manuel Antonio de Castro. São Paulo. Edições 70, 2010.

A questão da técnica. Trad. Marco Aurélio Werle. São Paulo:

Scientiae Studia. V. 5, № 3, 2007.

. El concepto de tiempo. Trad. Raúl Gabás Pallás y Jesús Adrian

Escudero. Madrid: Ed. Trotta, 2006.

. "... Poeticamente o homem habita..." In Ensaios e Conferências.

Trad. Marcia de Sá Cavalcante Schuback. Petrópolis: Vozes, 2008.

HORKHEIMER, Max. Sobre a metafísica do tempo de Bergson. Cadernos de Filosofia Alemã - USP. 2000.

JAMESON, Frederic. Pós-modernidade e sociedade de consumo. Trad. Vinícius Dantas. Novos Estudos Cebrap, no12. Junho, 1985.

JARDIM, Eduardo. A duas vozes: Hannah Arendt e Octavio Paz. Rio de Janeiro: Civilização Brasileira, 2007.

JIMENEZ-SANDOVAL, Saúl. Love, Memory and Being in Octavio Paz's Piedra de Sol In CANTU, R. The willow and the spiral. Newcastle: Cambrigde Scholars Publishing. 2014. 
LAFAYE, Jacques. Octavio Paz en la deriva de la modernidade. México: Fondo de Cultura Económica, 2013.

LAFER, Celso. Sobre Octavio Paz: vida e obra. In O que nos faz pensar. Paixão Crítica: 100 anos de Octavio Paz. Rio de Janeiro: PUC-RJ, 2015.

LAPOUJADE, David. Potências do tempo. Trad. Hortencia S. Lencastre. São Paulo. N-1. ed. 2013.

LE BRUN, Annie. História de um desastre in BRETON, A. Nadja. São Paulo. Cosac Naify. 2007.

LOWY, Michael. A estrela da manhã: surrealismo e marxismo. Trad. Eliana Aguiar. Civilização brasileira. Rio de Janeiro. 2002.

Walter Benjamin: aviso de incêndio: uma leitura das teses "Sobre o conceito de história". Trad. Wanda Nogueira Caldeira Brandt. São Paulo. Boitempo. 2005.

MACIEL, Maria Esther. As Vertigens da Lucidez: poesia e crítica em Octavio Paz. São Paulo: Experimento, 1995.

Janeiro: Sete Letras, 1999

. Voo transverso: Poesia, Modernidade e Fim do Século XX. Rio de

MALLARMÉ, Stephan. Um lance de dados. Trad. Haroldo de Campos. In CAMPOS, Augusto (Org.). Mallarmé. São Paulo: Perspectiva, 2013.

NIETZSCHE, Friedrich. Humano, demasiado humano IN Obras incompletas. Col. Os Pensadores. Trad. Rubens Rodrigues Torres Filho. São Paulo. Abril Cultural. 1983.

NUNES, Benedito. A questão do outro em Heidegger. Nat. hum., São Paulo, v. 3, n. 1, p. 51-59, jun. 2001.

. Crivo de Papel. São Paulo: Ed. Ática, 1998.

. No tempo do niilismo e outros ensaios. São Paulo: Edições Loyola, 2012.

OTTE, George. Algumas afinidades entre Octavio Paz e Walter Benjamin In MACIEL, Maria Esther (Org.) A palavra inquieta: homenagem a Octavio Paz. Belo Horizonte: Autêntica, 1999.

PAZ, Octavio. A busca do presente. Trad. Eduardo Jardim. Rio de Janeiro: Bazar do Tempo, 2017.

Águia ou Sol. Trad. Horácio Costa. México: Fondo de Cultura Económica, 2001. . Claude Lévi-Strauss ou o Novo Festim de Esopo. Trad. Sebastião Uchoa Leite. São Paulo, SP: Ed. Perspectiva, 1993 
Perspectiva, 1979.

Conjunções e Disjunções. Trad. Lucia Teixeira Wisnik. São Paulo: El mono gramatico. 3a ed. Barcelona: Seix Barral, 1990.

. El pensamiento en blanco In Obras Completas IV, Los privilegios de la vista: Arte Moderno universal, Arte de Mexico. México: Fondo de Cultura Económica, 2014.

- György Somlyó. Fábula del 28 de noviembro de 1968. In Obras Completas. Vol. VII. Cuidad de Mexico: Fondo de Cultura Económica, 2014.

. La Llama Doble. Barcelona: Seix Barral, 2001.

. La otra voz. In Obras Completas, Vol. 1, La Casa de La Presencia; Ciudad de México: Fondo de Cultura Económica, 2003.

. Libertad bajo palabra: obra poética (1935 - 1957). México: Fondo de Cúltura Económica, 1995.

Marcel Duchamp ou o castelo da pureza. Trad. Sebastião Uchoa Leite.

São Paulo: Ed. Perspectiva, 2008.

- Noturno de San Ildefonso. Trad. Horácio Costa In O que nos faz pensar. Paixão Crítica: 100 anos de Octavio Paz. Rio de Janeiro: PUC-RJ, 2015.

O Arco e a Lira. Trad. Ari Roitman e Paulina Wacht. São Paulo: Cosac Naify, 2012.

. O Labirinto da Solidão. Trad. Ari Roitman, Paulina Wacht. São Paulo: Cosac Naify, 2014.

. O ramo e o vento. Trad. Horácio Costa. Belo Horizonte: Autêntica Editora, 2012.

. Os Filhos do Barro. Trad. Ari Roitman e Paulina Wacht. São Paulo: Cosac

Naify, 2013

- Os Signos em Rotação. Trad. Sebastião Uchoa Leite. São Paulo: Perspectiva, 2009.

Pasado en claro. In In Obras Completas. Vol. VII. Cuidad de Mexico: Fondo de Cultura Económica, 2014.

. Pedra de Sol. Trad. Horácio Costa. São Paulo: Annablume, 2009.

. Poesia de Solidão e Poesia de Comunhão In A Busca do Presente. Trad. Eduardo Jardim. Rio de Janeiro: Bazar do Tempo, 2017.

. Sor Juana Inés de la Cruz ou As armadilhas da fé. Trad. Wladir Dupont. São Paulo: Ubu Editora, 2017

Tiempo Nublado. Barcelona: Ed. Seix Barral, 1996 
Topoemas In Signos em Rotação. Trad. Sebastião Uchoa Leite. São Paulo: Perspectiva, 2009 .; CAMPOS; Haroldo. Transblanco. São Paulo: Siciliano, 1994.

. Una apuesta vital. (Entrevista con Guillermo Sheridan). Vuelta, no 251. Octubre. México, 1997.

. Vislumbres da Índia: um diálogo com a condição humana. Trad. Olga Savary. São Paulo: mandarim, 1996

PESSANHA, Camilo. Clepsidra e poemas dispersos. Introdução biográfica e crítica, organização e notas de António Quadros. Lisboa: Publicações Europa-América, 1920.

PRADO JR, Bento. Presença e campo transcendental: consciência e negatividade em Bergson. São Paulo: Edusp, 1989.

PROUST, Marcel. Em Busca do tempo perdido. V.1. No caminho de Swann. Trad. Mário Quintana. São Paulo. Ed. Globo. 2006.

QUENTAL, Antero. Causas da decadência dos povos peninsulares. Lisboa: Ulmeiro, 1987.

RAYMOND, Marcel. De Baudelaire ao Surrealismo. Trad. Fúlvia M. L. Moretto; Guacira Marcondes Machado. São Paulo: Edusp, 1997.

RIMBAUD, Arthur. Rimbaud Livre. Trad. Augusto de Campos. São Paulo: Perspectiva, 2013.

SANTIAGO, Silviano. As Raízes e o Labirinto da América Latina. Rio de Janeiro: Rocco, 2006.

SARDUY, Severo. Barroco. Buenos Aires: Sudamericana, 1974.

SCHWARZ, Roberto. As ideias fora de lugar In Ao vencedor as batatas. São Paulo: Duas Cidades - 34, 1992.

SILVA, Franklin Leopoldo. Bergson: intuição e discurso filosófico. São Paulo: Loyola, 1994. Martin Heidegger e a técnica. São Paulo: Scientiae Studia. V. 5, № 3, 2007.

SILVA, Lourenço Fernandes. O animal em Condillac ou as Reinvenções do Humano. Dissertação (Mestrado) São Paulo: Faculdade de Filosofia, Letras e Ciências Humanas. Depto. de Filosofia, 2015.

SOMLYÓ, György. O poeta do tempo capturado. In MACIEL, Maria Esther (Org.) A palavra inquieta: homenagem a Octavio Paz. Belo Horizonte: Autêntica, 1999.

STANTON, Anthony. Octavio Paz y los "contemporáneos": la historia de una relación. In Vilanova, A. ed., Actas del X Congreso de la Asociación Internacional de Hispanistas. Barcelona: Univ. De Barcelona/ PPU, 1992. 
TV PUC-Rio. Paixão Crítica, Octavio Paz. 2015. Disponível em: https://youtu.be/ysxMMKaE4xQ (Acesso em 30 de Maio de 2019).

ULACIA, Manuel. El arbol milenário: Um recorrido por la obra de Octavio Paz. Barcelona: Galaxia Gutenberg/ Círculo de Lectores, 1996. 